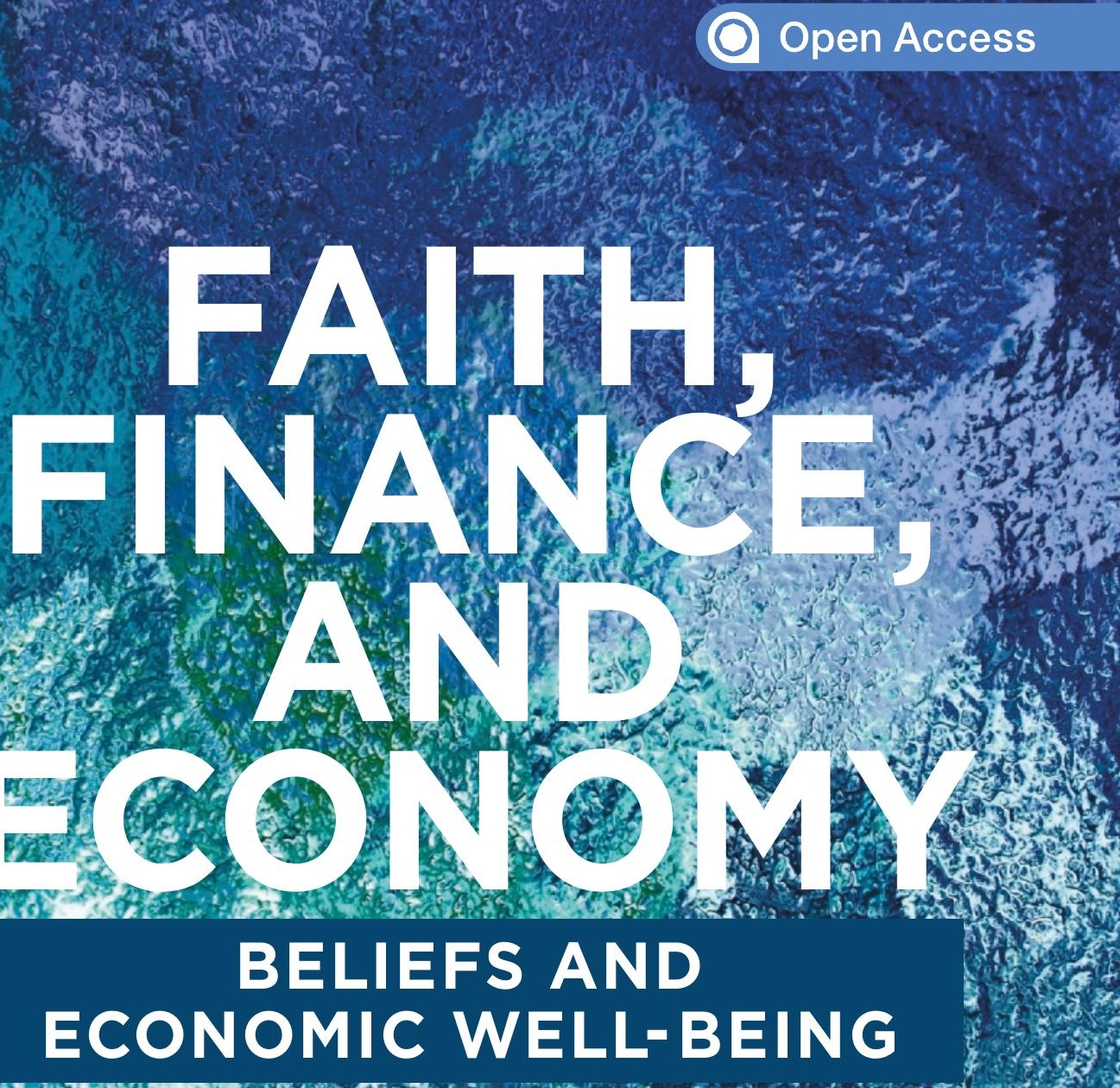

BELIEFS AND
ECONOMIC WELL-BEING

Hen

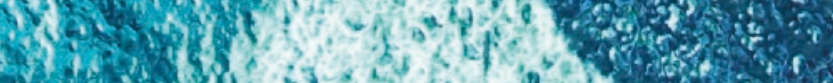

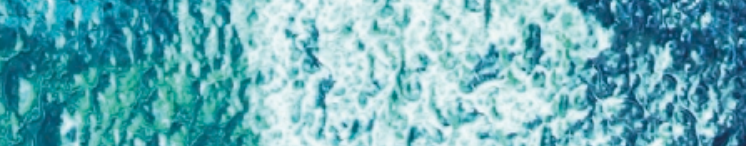

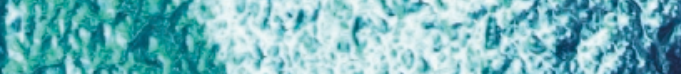

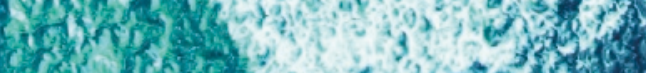

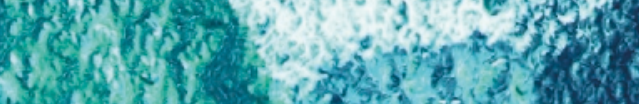

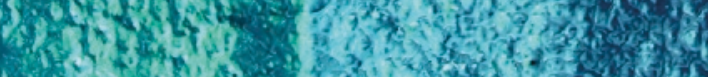

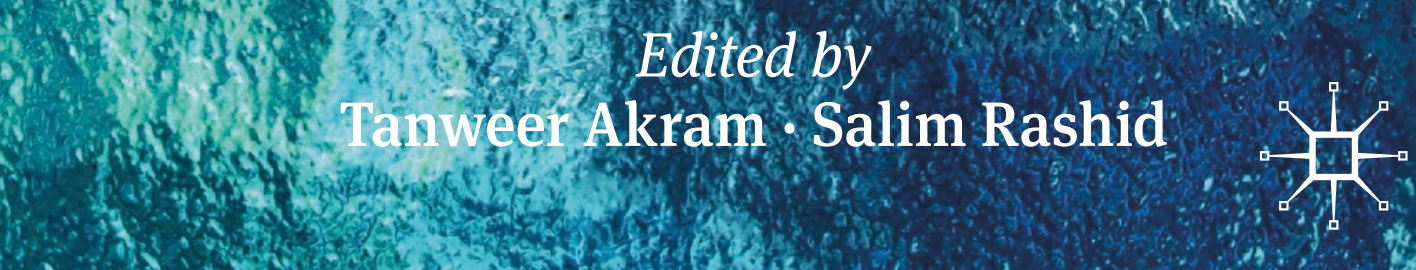




\section{Faith, Finance, and Economy}

"The connections between faith and finance are fundamental for a flourishing economy, as every banker and policymaker should know. Given the challenges of global finance in this century, however, one wonders how faith may succeed in confronting the inequalities and injustices that arise? It takes scholars from different faiths and disciplines to analyze and solve these problems. The essays in this volume give readers hope that faith, deeply understood, can overcome the intrinsic dilemmas of finance, even on today's global scale."

-Larry D. Neal, Professor Emeritus of Economics, University of Illinois at Urbana-Champaign

"The authors of this important volume of essays wrestle with questions such as: What is the best arrangement for creating wealth and reducing inequality and poverty? How does God, as interpreted by several major faiths, want society organized so that the economic system allows all humans to flourish? Is liberty compatible with inequality in income and wealth? Can humanity manage the juggernaut of rampant consumerism? What foundational contributions to Economic Development were made by Anglican Clergymen such as GeorgeBerkeley, Josiah Tucker and Jonathan Swift? What does Islamic finance offer in the area of ethical investments and modern-day finance? How have modern corporations navigated issues of faith in the workplace? Finally, what is meant by 'moral ecology' as practiced in Catholic social teachings? One hopes the book will be widely read by students of religion, economics and business for a better understanding of our world."

- Munir Quddus, Dean of the College of Business, Prairie View A\&M University

"A comprehensive study of economic life and ideas in modern society cannot ignore the religious culture in which they occur. This highly interesting collection of essays is a valuable contribution to that study."

-A. M. C. Waterman, Professor Emeritus of Economics, University of Manitoba 


\section{Tanweer Akram · Salim Rashid Editors}

\section{Faith, Finance, and Economy}

Beliefs and Economic Well-Being 


\section{Editors}

Tanweer Akram

Thrivent

Minneapolis, MN, USA
Salim Rashid

Emeritus Professor, Department

of Economics

University of Illinois-Urbana

Champaign

Urbana, IL, USA

University Professor

East West University

Dhaka, Bangladesh

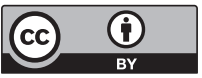

ISBN 978-3-030-38783-9

ISBN 978-3-030-38784-6 (eBook) https://doi.org/10.1007/978-3-030-38784-6

(C) The Editor(s) (if applicable) and The Author(s) 2020. This book is an open access publication.

Open Access This book is licensed under the terms of the Creative Commons Attribution 4.0 International License (http://creativecommons.org/licenses/by/4.0/), which permits use, sharing, adaptation, distribution and reproduction in any medium or format, as long as you give appropriate credit to the original author(s) and the source, provide a link to the Creative Commons license and indicate if changes were made.

The images or other third party material in this book are included in the book's Creative Commons license, unless indicated otherwise in a credit line to the material. If material is not included in the book's Creative Commons license and your intended use is not permitted by statutory regulation or exceeds the permitted use, you will need to obtain permission directly from the copyright holder.

The use of general descriptive names, registered names, trademarks, service marks, etc. in this publication does not imply, even in the absence of a specific statement, that such names are exempt from the relevant protective laws and regulations and therefore free for general use. The publisher, the authors and the editors are safe to assume that the advice and information in this book are believed to be true and accurate at the date of publication. Neither the publisher nor the authors or the editors give a warranty, expressed or implied, with respect to the material contained herein or for any errors or omissions that may have been made. The publisher remains neutral with regard to jurisdictional claims in published maps and institutional affiliations.

This Palgrave Macmillan imprint is published by the registered company Springer Nature Switzerland AG

The registered company address is: Gewerbestrasse 11, 6330 Cham, Switzerland 


\section{Preface}

Faith and finance may appear at first glance to be two different and disconnected subjects. However, this book shows the deep and intricate connection between faith and finance in different countries, societies, and eras. This book is addressed not just to economists, investment professionals, theologians, and philosophers, but also to the public as well as policymakers.

Faith, Finance and Economy is an edited volume consisting of chapters written by scholars from many academic disciplines, including theology, philosophy, history, law, economics, and business. While the scholars represented in the book do come from a variety of philosophical perspectives, they share a common interest in the connections between faith and finance. The chapters are based on papers that the scholars presented at a conference that was organized and sponsored by Thrivent and held on July 24, 2018 at the University of St. Thomas in Minneapolis, Minnesota. It was a pleasure for us to work with these scholars. We thank them for their contributions and many convivial conversations.

We also thank Thrivent for organizing the conference and supporting the publication of this book. We also thank the following for their support for many different aspects of this book: Callie Briese, Brad Hewitt, Karen Himle, Ann Jonell, Rick Kleven, Chris Kopka, Joanna Reiling Lindell, William B. McKinney, Samantha Mehrotra, Mary Rafferty, Teresa J. Rasmussen, Joan Rushton, Jim Thomsen, Mark Wagner, and two anonymous referees. We also appreciate the efforts of Elizabeth Graber, Sophia Siegler, and other staff of the publisher in copyediting 
and typesetting, and in performing various tasks that were essential to getting this book published.

The standard disclaimers apply. The authors' institutional affiliations are provided solely for identification purposes. Views expressed are solely those of the authors and are not necessarily those of Thrivent, Thrivent Asset Management or any affiliates.

Minneapolis, USA

Tanweer Akram

Urbana, USA

Salim Rashid

November 2019 


\section{Contents}

1 Introduction 1

Tanweer Akram and Salim Rashid

2 Christian Faith and Economics 15

Ronald J. Sider

3 Biblical Stewardship and Economic Progress 31

Anne Rathbone Bradley

4 Rationality and Alienation: Themes from Gandhi 53

Akeel Bilgrami

5 Consumerism in Contemporary China 75

Karl Gerth

6 Anglican Christians and Modern Political Economy 107

Salim Rashid

7 Islamic Finance, Consumer Protection and Public Policy

Faisal Kutty 
viii CONTENTS

8 Christianity and Inequality in the Modern United States

Heath W. Carter

9 Faith and Work: Brave New World?

David W. Miller

10 The Moral Ecology of Good Wealth Michael Naughton

Name Index

Subject Index 


\section{Notes on Contributors}

Tanweer Akram is Director of Global Public Policy and Economics at Thrivent, USA. He is responsible for developing the firm's views on international financial regulations. He also conducts research on global macroeconomic trends, outlook, and risks. He has published extensively in economics and finance journals.

Akeel Bilgrami is Sidney Morgenbesser Professor of Philosophy at Columbia University, USA, where he is also on the Committee on Global Thought. He was the director of the Humanities Center at Columbia University for seven years and is currently the director of its South Asian Institute. His publications include the books Belief and Meaning, Self-Knowledge and Resentment and Secularism, Identity, and Enchantment. He is due to publish two short books in the near future: What Is a Muslim? and Gandhi's Integrity.

Anne Rathbone Bradley is Academic Director for The Fund for American Studies, USA and Vice President of Economic Initiatives at the Institute for Faith, Work \& Economics. She is Professor of Economics at The Institute for World Politics and Grove City College. She is also a Visiting Professor at Georgetown University and George Mason University. Dr. Bradley is the coeditor and author of Counting the Cost: Christian Perspectives on Capitalism, For the Least of These: A Biblical Answer to Poverty, and Be Fruitful and Multiply: Why Economics Is Necessary for Making God-Pleasing Decisions. 
Heath W. Carter is Associate Professor of American Christianity at Princeton Theological Seminary, USA. He is the author of Union Made: Working People and the Rise of Social Christianity in Chicago. He is also the coeditor of three books: The Pew and the Picket Line: Christianity and the American Working Class, Turning Points in the History of American Evangelicalism, and A Documentary History of Religion in America. Dr. Carter is currently working on a new book entitled $O n$ Earth as It Is in Heaven: Social Christians and the Fight to End American Inequality.

Karl Gerth is Hsiu Endowed Chair in Chinese Studies in the Department of History at the University of California, San Diego, USA. Earlier he taught at the University of South Carolina and Oxford University. His latest book, As China Goes, So Goes the World: How Chinese Consumers Are Transforming Everything, explores whether Chinese consumers can rescue the economy without creating even deeper global problems. His first book, China Made: Consumer Culture and the Creation of the Nation, examines the connections between nationalism and consumerism in China in the first half of the twentieth century.

Faisal Kutty is Associate Professor of Law, Emeritus at Barry University Law School, USA and at Osgoode Hall Law School of York University in Toronto, Canada. He serves as counsel to KSM Law, a law firm that he cofounded. He has acted as legal counsel to various Islamic finance companies. His research and teaching interests include Islamic law, Islamic finance, religion and law, international law, human rights, comparative law, and national security.

David W. Miller is Director of the Faith \& Work Initiative, Lecturer of Religion, and Professional Specialist at the Center for the Study of Religion, all at Princeton University, USA. He also serves as an advisor to corporate CEOs and senior executives on ethics, values-based leadership, culture change and the role of faith at work. Prior to academia, David lived and worked in London for eight years, where he was a partner in a private equity firm that specialized in international investment management, corporate finance, and mergers and acquisitions.

Michael Naughton is Director of the Center for Catholic Studies at the University of St. Thomas, Minnesota, USA. He holds the Koch Chair in Catholic Studies and is a full professor in the department of Catholic 
Studies. Professor Naughton is author, coauthor and coeditor of nine books and more than 50 articles. He helped coordinate and write the Vocation of the Business Leader issued by the Pontifical Council for Justice and Peace. His most recent coauthored book is Respect in Action: Applying Subsidiarity in Business. He is also the coauthor of Managing as If Faith Mattered.

Salim Rashid is Professor Emeritus at the University of Illinois, UrbanaChampaign, USA and University Professor at East West University, Dhaka, Bangladesh. He has published in the areas of mathematical economics, economic methodology, monetary economics, economic development, and the history of economics. His current interests are in the areas of religion and economic development and the limitations of mathematical methods in economics. After retiring he taught in Fiji, India, and Malaysia. He visits Bangladesh regularly to advance the cause of rural urbanization as a means to achieve $10 \%$ economic growth.

Ronald J. Sider is Distinguished Professor Emeritus of Theology, Holistic Ministry, and Public Policy at Palmer Theological Seminary, USA and President Emeritus of Evangelicals for Social Action. In 1982, The Christian Century named him one of the twelve "most influential persons in the field of religion in the U.S." His book, Rich Christians in an Age of Hunger, was recognized by Christianity Today as one of the 100 most influential religious books of the twentieth century. He was the publisher of PRISM magazine and a contributing editor of Christianity Today for 20 years. He is a contributing editor of Sojourners. 


\section{Introduction}

\section{Tanweer Akram and Salim Rashid}

How can the abacus be combined with that which cannot be crushed in the crucible or weighed in the balance? And yet, such is the paradoxical attempt of this volume on Faith, Finance, and Economy. Since bookkeeping arithmetic is coolly amoral about profits and losses, to persuade a mercantile age that faith may exert any influence on finance, we need to argue in terms with which merchants are familiar. It must be shown that either the demand or the supply of finance can be shifted by those who are guided by the unseen.

Once one starts looking, however, the evidence seems so plentiful that one is led to wonder how people could have thought otherwise. The "transcendent importance" of religion and faith is obvious if one looks

T. Akram $(\bowtie)$

Thrivent, Minneapolis, MN, USA

S. Rashid

Emeritus Professor, Department of Economics, University of Illinois-Urbana

Champaign, Urbana, IL, USA

e-mail: srashid@illinois.edu

University Professor, East West University, Dhaka, Bangladesh

(C) The Author(s) 2020

T. Akram and S. Rashid (eds.), Faith, Finance, and Economy, https://doi.org/10.1007/978-3-030-38784-6_1 
carefully. ${ }^{l}$ Long-distance trade between the Mediterranean nations and India took place with generations of merchants who had contacts in major ports and who began letters with the significant expression of trust: "I am in your place as you are in mine." The earliest successful banks of Italy were run for profit, but their profits were submitted to a charitable trust. In the city where Thrivent is located, Minneapolis-St Paul, the wealthiest merchants got together soon after they achieved success and agreed to dedicate $10 \%$ of their profits to the community. Because it is not-in their nature-noisy or flashy, faith-based initiatives run as a subterranean stream beneath the hubbub of civilization. We are still coming to a full understanding of the ways in which faith suffused the commercial life of the West for a thousand years. This volume is an attempt to show the conceptual richness of the framework that seeks to leaven finance with faith, the effectiveness of the synergy, and the pitfalls it encounters in practice.

The rest of this introduction provides a guide to the objectives of this book and its sponsors, and a brief guide to its contents. After that, we flesh out in brief a general schema within which the general societal impact of faith and finance can be understood.

\section{The Objectives of This Book}

The main objective is to foster a multidisciplinary and multireligious understanding of the ties among faith, financial intermediation and economic progress, drawing on research in economics, finance, history, philosophy, ethics, theology, public policy, law and other disciplines. This collection of essays is meant to show the importance of religious engagement with finance to the general public. The collection of essays provides many different examples of this connection rather than develop a single theme.

In July 2018, Thrivent organized a conference-held at the University of St. Thomas in Minneapolis, Minnesota-on the topic of faith and finance. Thrivent was solely responsible for financing the conference. The conference brought together some of the leading scholars and thought leaders on major world traditions from a range of academic institutions. This book, based on the papers presented, is an outcome of the

${ }^{1}$ Whitehead Alfred North (1996 [1926]). Religion in the Making. New York, NY: The Free Press. 
conference. This book is meant for a general audience, for the reader curious about the intersections of faith and finance.

A critical exchange of ideas about faith and finance is useful not only to scholars but also to policymakers, entrepreneurs and community members. Understanding the connection between faith and finance is relevant for contemporary policy debates about business development, entrepreneurship, the role of not-for-profits in community development and the missions of faith-inspired organizations in an ever-changing world. Indeed, it is even relevant for issues of corporate culture/ethics, the role of leverage, the remuneration of talent, and a host of other issues, as will be discussed in the chapters that follow. The conference was not designed to achieve an integration of different viewpoints but rather to explore different perspectives and experiences regarding the multiple connections between faith and finance. The overall aim is to convince the reader that faith and finance are not disjoint entities.

\section{Some Information About Thrivent}

Thrivent is a not-for-profit financial services organization that serves Christians and their families in the United States. It is a fraternal benefit society. As a mission-driven, membership-owned organization, it offers its more than two million members and customers a broad range of financial products, services and guidance to help them obtain a life of contentment, confidence and generosity. Thrivent and its subsidiary and affiliate companies offer insurance, investments, banking and advice over the phone and through online digital channels, as well as through financial professionals and independent agents nationwide. For more than a century, it has helped Christians make financial choices that reflect their values while providing them opportunities to demonstrate their generosity where they live, work and worship.

Thrivent has sponsored this book in the hope that it will facilitate the valuable exchange of ideas about what faith-inspired organizations and communities do-and could do-to address the challenges of economic and social problems, particularly during times of economic recession, financial crisis, natural disasters, polarization, rapid technological changes, globalization and other challenges. Thrivent commissioned the contributors of the book to write papers on the connection between faith and finance from their own point of view. However, the views expressed in the papers contained in this edited volume are solely those of the authors of each paper. The standard disclaimers apply. 


\section{An Overview of the Chapters}

The second and third chapters of this book concern economic opportunities, real-world outcomes and faith. Two perspectives, both based on the authors' interpretations of the Christian faith, are represented in these chapters.

In Chapter 2, Ron Sider, a professor of theology, says that the biblical canon provides the normative framework for his economic and political views. He believes that human beings are created in the image of God and therefore are immeasurably precious. Although he acknowledges that a market economy is a better way to organize economic life than a stateowned, state-run and collectivist economy, Sider argues that today's market economies have several weaknesses, such as the absolute poverty of a significant segment of the world's population, the immense concentration of wealth, and a highly skewed distribution of income. This, he says, is unjust and destructive. He holds that the state's economic domain should be limited, but that the state must act to redistribute wealth and income in ways that empower poor and disadvantaged persons and create opportunities for progress so that all human beings can flourish.

In Chapter 3, Anne Rathbone Bradley, an economist, presents a market-process viewpoint, influenced by the "Austrian" school of economic thought. Bradley also believes that human flourishing is what God desires for his people and his creation. She holds that Genesis reveals not only God's desires but his designs for human beings and provides the basis for human beings to unleash creativity in ways that both advance and cultivate God's creation and makes eternal contributions through wealth creation for the common good. The economic way of thinking provides rational principles of human action and the implementation of human creativity. Bradley believes that this necessitates a market economy where individuals can discover, learn and-through the system of profits and losses-find ways to serve one another. She argues that when society is ordered in a way that allows these market principles to work unfettered by excessive state interventions and distortions, they will foster greater human flourishing.

The next two chapters explore the issues of values and consumerism. It brings perspectives from a philosopher and a historian.

Akeel Bilgrami's philosophical argument in Chapter 4 is inspired by Mahatma Gandhi, who believed that ethics is a primarily perceptual discipline. Bilgrami argues that Gandhi's way of thinking puts the notion of the unalienated life as the most fundamental political ideal. As a result, 
liberty and equality are treated no longer as central ideals, but as merely necessary conditions for a fundamental human ideal in a way that removes the tension between liberty and equality that has been present in the liberal traditions of the West. All three notions-liberty, equality and the unalienated life-should be connected, argues Bilgrami. He calls for a notion of "unalienatedness" that is not the same as the one of premodernity with its absence of liberty and equality. Rather, he holds there is a notion of liberty, based on this concept of the unalienated life, that would not generate inequalities, as seen in the world today, while preserving liberty. In the framework that Bilgrami proposes, "unalienatedness" is not conceived individualistically. This is consistent with Gandhi's way of looking at human life and society.

Karl Gerth, a historian, examines the rise of consumerism in contemporary China in Chapter 5. He explores the spread of the defining value of consuming - a person is what he or she consumes. Gerth's analysis leads him to two conclusions. First, consumerism is embedded in industrialization and contemporary capitalism. Second, consumerism does not spread spontaneously, but is often promoted by the state. He argues that the history of China since the Communist Revolution in 1949 suggests that the industrializing state, whether "capitalist" or "socialist," has played a critical role in spreading consumerist values. Because humans and their institutions-not "human nature"-create consumerism, the possibility of promoting non-consumerist alternative values such as egalitarianism, civic-mindedness and spirituality still exists in China. Even amid the rapid spread of consumerism, non-consumerist values to resist this spread can arise and lead to various movements and changes in lifestyle. But it remains to be seen whether non-consumerist values will emerge over time in China, or whether crass consumerism will predominate.

The next two chapters cover issues of faith, financial intermediation and economic development in Western and Islamic societies.

In Chapter 6, Salim Rashid, an economist, shows the critical role of Anglican clergymen as pioneers in the theoretical conception of modern economic development. He examines some ideas advanced by three well-known Anglican clergymen-George Berkeley, Josiah Tucker and Jonathan Swift-because their ideas played an important role in economic development in the United Kingdom during the early years of industrialization and capitalism. Berkeley held that: (1) economic development must bring about a better life for the common person, (2) human capital is necessary for economic growth and (3) monetary (and financial) development is a necessity for enabling economic activity and growth. Tucker 
argued that a richer country possesses certain economic advantages that enable it to stay ahead of a poorer, labor-abundant country. Jonathan Swift recognized that poor countries not only need sound economic policies to grow, but also a dedicated, committed and visionary elite that can implement growth-oriented policies and institute reforms. The figures mentioned by Rashid do not appear in most textbooks in the history of economic thought and hence most students of economic development do not know of the role of these Anglian clergymen in pioneering many of the basic concepts of economic development. Such neglect in the standard sources is an important reason why the educated reader feels faith and finance to belong to different spheres of life.

Faisal Kutty, an attorney who also teaches at law schools in the United States and Canada, offers a critical overview of Islamic finance in Chapter 7. He provides not just a primer on Islamic finance, but also examines the myriad of regulatory and legal issues, including consumer protection concerns, pertaining to it. He argues that Islamic finance, in theory, has much to offer to global finance, but its current practice falls far short of Islamic economic and ethical ideals. Islamic finance as it exists in practice today only marginally implements Islamic principles in many cases. Debate exists about whether the instruments used in the Islamic finance industry reflect genuine profit/loss sharing. There is also some debate about the use of leverage and interest-based financial services. Nevertheless, Kutty is optimistic that if the industry and the government regulators address the concerns and complaints made by a growing number of critics, Islamic finance has promise.

The last three chapters of the book take a perspective informed by an analysis of the impact of faith issues on the plight U.S. workers, on the workplace and religion, and on the characteristics of good wealth.

Heath Carter, a historian, argues in Chapter 8 that if one wants to understand the new Gilded Age of renewed inequality of income and wealth in the United States, one must attend to its spiritual origins because the teaching and the interpretation of Christianity influences public attitudes. In the original Gilded Age, a series of grassroots movements sent a shock wave. This resulted in the Church adopting new social teachings. Social Christian teachings also influenced the institutions of the state. However, in response to these changes, Christian libertarianism has had a resurgence, particularly since the beginning of the 1970s. This, in turn, has led to the transformation of the social and ethical institutions of Christians in the United States. He argues that this has favored the rise 
of the new Gilded Age, characterized by increased inequalities of income, wealth, economic opportunity and well-being.

David W. Miller, a scholar of ethics and business and specialist in studying the faith-at-work movement, discusses the relationship between faith and the workplace in Chapter 9. The conventional wisdom has been to keep faith separate from business, but there have been notable changes in recent years as companies claim to be more accepting of - and in some cases, embracing-employees who wish to bring their faith to work. However, this poses several challenges, which Miller addresses. He notes that while there are potential benefits to both employers and employees, there are also potential problems if not implemented carefully. Miller offers a constructive way forward to attain the potential benefits for companies and their employees while minimizing the pitfalls. He argues that companies that design and embrace faith-friendly policies and practices will find it advantageous both to the employees and to the company's bottom line.

In Chapter 10, Michael Naughton, a professor of Catholic studies and business, defines good wealth in terms of wealth's creation, distribution and charitable dimensions from a Catholic perspective. He believes businesses are the key engine for economic growth. Profit is important, but he maintains that profit cannot be an end in itself. A just distribution of wealth is vital for the economy and for society. Furthermore, the charitable function of wealth defines what is "good wealth." Naughton speaks of three principles of a just wage: need, contribution and sustainability. $\mathrm{He}$ acknowledges that there are tensions among these three principles of wealth, but he points to some innovative practices of integrating them. He also provides a case study to show how these three principles of good wealth can be successfully integrated.

\section{A Brief Comparison to the Existing Literature}

In order to differentiate this volume from the extant literature, it may be helpful to summarize the faith and finance issues covered and the viewpoints represented in this volume.

- Sider (Chapter 2) and Bradley (in Chapter 3) both ask how faith can provide an overarching framework for finance and economy? They provide different visions but their visions are inspired by their interpretations understanding of the fundamental teachings of Christianity. 
- Bilgrami (in Chapter 4) and Gerth (in Chapter 5) address what are the philosophical and practical challenges of connecting faith and finance. Both perspectives arise outside Christianity, and indeed, outside the Abrahamic faiths.

- Rashid and Carter both address the extent to which faith has involved itself in seeking solutions for general policy issues. Rashid (in Chapter 6) discusses how Christian clergymen envisioned the role of faith, economy and finance in economic development, while Carter (in Chapter 8) analyzes the role of grassroots movements and the effect of new social teachings on the public's attitudes to inequality - whether it be income or wealth inequality - in the past.

- Miller (in Chapter 9) and Naughton (in Chapter 10) examine the continuing attempts to implement a framework which connects faith and finance even in today's corporate America, while Kutty (in Chapter 7) writes about the challenges of applying Islamic economics and ethics in modern banking systems, particularly when based in western societies.

In terms of the width of issues, interdisciplinary approaches and ecumenical interpretation of faith, we find the nearest volume to be that edited by Ian Harper and Samuel Gregg (2008). ${ }^{2}$ However, that volume is now a decade old, focused solely on Christianity, and written in a style that would appeal largely to academics. This is not to deny that there is a substantial literature on the confluence of faith, economy and finance, mostly focusing on the idea of trust. This existing literature consists either of financial advice for Christians who wish to manage their personal finances - the older meaning of economy as household management-or it consists of practitioners guides to investing with a conscience. Much of this existing literature deals with the duty of charity and elaborates on the emphasis given on this duty in Christianity. Some of it is very learned ${ }^{3}$ [while others give faith-based associations an "also ran" in volumes on social reform]. ${ }^{4}$ The seriousness with which Christians take

\footnotetext{
${ }^{2}$ Harper, Ian and Gregg, Samuel, eds. (2008). Christian Theology and Market Economics. Cheltenham, UK and Northampton, MA: Edward Elgar.

${ }^{3}$ For example Clark, Henry (1965). The Christian Case Against Poverty. New York, NY: Association Press.

${ }^{4}$ Palmer, Tom (2012). After the Welfare State. Ottawa, IL: Jameson Books.
} 
the duty of practicing their faith is remarkable and justifies limiting our attention, in a first sally at such a wide-ranging topic, to such authors. By contrast, while the duty of charity and the merits of trade are repeated ad nauseam by Islamic economists, the minute portion of Islamic finance that is actually conducted under the distinguishing hallmark of Islamic economics-profit sharing - suggests that lip service is being paid.

There is a general lack of awareness of the historical impact of faith and its future potential. When one looks, there are connections to be extracted in volumes of financial histor ${ }^{5}$ - or within development anthropology. 6 These connections do not rise to one's attention because the recent focus has been on displaying religion as a profit-making construct by economic imperialists or as a survival adaptation by evolutionary biologists. However, we take faith as sufficiently established and important while neither finance nor economy needs independent justification.

\section{Christianity in THE Discussions OF FAITH AND FinANCE}

Although this introduction has covered many different traditions, the dominance of Christianity in the discussions throughout the book is apparent and needs some amplification. First, Christianity has been the dominant religion of the western world for the last thousand years or more. Its impact will be more readily appreciated by readers in the English language. Second, a wealth of primary materials is available for studying the interplay of faith and finance as envisioned in this discussion. Decisive historical knowledge often turns upon critical detail; unless we have access to the primary sources, such details are hidden from sight. Third, we not only want to look at the influence faith has upon finance, but also the guidance-or misdirection - faith may have given finance. This focuses attention more closely on those faiths that have directly engaged with the economy, and this brings Christianity and Islam directly to mind. Fourth,

\footnotetext{
${ }^{5}$ Costabile, Lilla and Neal, Larry (2018). Financial Innovation and Resilience: A Comparative Perspective on the Public Banks of Naples (1462-1808). Palgrave Studies in the History of Finance (London, UK: Palgrave Macmillan).

${ }^{6} \mathrm{McD}$ aniel, Justin Thomas (2018). "The Goddess of Old Money: The Chettiar Bankers of India and Their Temples in Southeast Asia." Material Religion: The Journal of Objects, Art and Belief 4(1): 115-126.
} 
while all religions ascribe power and benevolence to the Creator, Christianity has given substantial importance to the co-equal status of God's power and God's love. This is at once the peculiar attraction and problem of Christian theology and makes the engagement of Christianity with the world more self-conscious and revealing. Finally, one often forgets how modern Europe has tried to disengage from its Christian past, thereby making an understanding of the last 200 years limited and confusing. If one goes to the webpage of the European Union (EU) and looks for its origins, there is almost nothing about Christianity, even though the flag of the EU still has 12 stars as in the crown of Mary. How extraordinary, when some of the EU's founders were inspired by Christian values and believed that common Christian values of the European nations provided a sound basis for creating a community of nations, developing trust, peace and security and economic and political cooperation. ${ }^{7}$

If a multireligious study of faith and finance is to be fruitful, it should map out the major questions that display the interaction of faith and finance; such a framework is essential if we are to not meander from one case to the next. The framework should have economic content and should involve the structure of society, since finance is a part of economics and economies are ensconced within societies. The following five criteria seem to be beneficial in establishing the many ways in which faith permeates economy and finance. For convenience, they are referred to as "ethics," not just because popular usage already identifies some of the features as such, but because it is necessary to remember that the fulfillment of these ethics is often based on deeper motives than money can reach.

First is the rule of law, or the legal ethic. Second, the value of work, or the work ethic. Third, the desirability of consuming, or the consumption ethic. Fourth, the benefits of science, or the knowledge ethic. Finally, the need for unconditional acceptance, or the support ethic. To argue in detail why each one is essential and how they fit together would require too much space, but perhaps a few words on the work ethic will show why many existing frameworks for studying the impact of religion on the economy are inadequate.

\footnotetext{
${ }^{7}$ Kaiser, Wolfram (2007). Christian Democracy and the Origins of European Union. Cambridge, UK and New York, NY: Cambridge University Press.
} 
Max Weber made the work ethic famous with his thesis that Calvinism galvanized capitalism by providing a dour desire to work indefinitely. However, if a society really were full of hardworking and thrifty Calvinists and they saved, invested and produced, who would be buying the mountains of goods that kept coming? Without a consumption ethic, the work ethic is incapable of sustaining a capitalist society. The point of wider significance that arises from this analysis is that the requirements for a capitalist society may come in "opposite pairs," as in the consumption ethic and the work ethic; it has particular importance because the consumption ethic was probably the hardest of the ethics for Christian societies to accept.

\section{The Importance of Faith and Finance Issues}

The importance of religion has been long recognized by many eminent scholars, such as Alfred North Whitehead, who wrote: "Religion is the vision of something which stands beyond, behind, and within, the passing flux of immediate things; something which is real, and yet waiting to be realized; something which is a remote possibility, and yet the greatest of present facts; something that gives meaning to all that passes, and yet eludes all apprehension; something whose possession is the final good, and yet is beyond all reach; something which is the ultimate ideal, and the hopeless quest." 8 Nevertheless, in this mercantile age, both the general public and the economics profession have either neglected or underestimated the explicit and implicit role of faith in economic institutions, and within the social framework. The chapters in this book show that faith influences people's worldview, their conduct of business and finance, attitudes toward income inequality, consumption, entrepreneurship and risk-taking, and corporate and work culture. Perhaps this book will help redress the prevalent neglect of the role of faith by pointing out such connections.

The book covers substantial ground even though the book explores only a few select issues in faith and finance. Obviously, there are many other viewpoints, from various faiths, and from a variety of perspectives within any faith. Many interesting and relevant and complex topics are related to faith and finance, but a comprehensive analysis of all the issues

\footnotetext{
${ }^{8}$ Whitehead, Alfred North (1967 [1926]). Science and the Modern World. New York, NY: The Fordham University Press.
} 
of faith and finance is well beyond the scope of any single book, let alone this collection of essays. The following chapters show the diversity of perspectives and practical connections between faith and finance among many different communities and domains.

If this book serves to catalyze, perhaps even to generate-in the near future-open-minded scholarly work and policy discussions and debates about how faith influences economic decision-making, it will have served a valuable purpose. We look forward to the greater involvement, both in terms of its visibility as well as its depth, of faith in such issues as financial well-being and security, economic institutions, saving behavior, the accumulation of capital, business ethics and practices, workers' attitudes, national policies, corporate culture, and the visions of entrepreneurs and business leaders. That is, to remind us of that faith can influence business and economic activity as well as social and cultural developments at regional, national and global levels. Since religions must survive, economic factors such as the profit-motive and social sustenance often affect faith but this book shows that religion and faith also have a pervasive role in molding economics and finance-a role that requires careful and detailed analysis.

\section{BIBLIOGRAPHY}

Clark, Henry. The Christian Case Against Poverty. New York, NY: Association Press, 1965.

Costabile, Lilla and Larry Neal. Financial Innovation and Resilience: A Comparative Perspective on the Public Banks of Naples (1462-1808). Palgrave Studies in the History of Finance. London, UK: Palgrave Macmillan, 2018.

Harper, Ian and Samuel Gregg, eds. Christian Theology and Market Economics. Cheltenham, UK and Northampton, MA: Edward Elgar, 2008.

Kaiser, Wolfram. Christian Democracy and the Origins of European Union. Cambridge, UK and New York, NY: Cambridge University Press, 2007.

McDaniel, Justin Thomas. "The Goddess of Old Money: The Chettiar Bankers of India and Their Temples in Southeast Asia." Material Religion: The Journal of Objects, Art and Belief 4, no. 1 (2018): 115-126.

Palmer, Tom. After the Welfare State. Ottawa, IL: Jameson Books, 2012.

Whitehead, Alfred North. Science and the Modern World. New York, NY: Fordham University Press, 1967 [1926].

Whitehead, Alfred North. Religion in the Making. New York, NY: The Free Press, 1996 [1926]. 
Open Access This chapter is licensed under the terms of the Creative Commons Attribution 4.0 International License (http://creativecommons.org/licenses/ by $/ 4.0 /$ ), which permits use, sharing, adaptation, distribution and reproduction in any medium or format, as long as you give appropriate credit to the original author(s) and the source, provide a link to the Creative Commons license and indicate if changes were made.

The images or other third party material in this chapter are included in the chapter's Creative Commons license, unless indicated otherwise in a credit line to the material. If material is not included in the chapter's Creative Commons license and your intended use is not permitted by statutory regulation or exceeds the permitted use, you will need to obtain permission directly from the copyright holder.

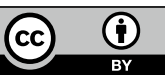




\title{
Christian Faith and Economics
}

\author{
Ronald J. Sider
}

Every person's views on economic issues and the political judgments that interrelate with them have four components: (1) a normative framework; (2) a broad study of society (using disciplines such as economics, history, and politics); (3) an economic/political philosophy; and (4) more detailed study relevant to any specific issue. Most people, to be sure, do not think consciously about these four components. But they are present nonetheless.

For example, consider the great twentieth-century debate between advocates of a market economy and a state-owned and controlled economy. Everyone involved in the debate embraced some normative framework that included ideas about the nature of persons and justice. Everyone thought (or just assumed what their society told them) about the study of economics and the history of different types of economic arrangements. Everyone (consciously or not) combined their normative framework and their broad study of economics and society to form an economic/political philosophy which served as a road map or handy guide when making detailed economic decisions. Finally, everyone thought carefully about (or again, simply accepted the assumptions of

R. J. Sider $(\bowtie)$

Palmer Theological Seminary, Wayne, PA, USA

(C) The Author(s) 2020

T. Akram and S. Rashid (eds.), Faith, Finance, and Economy, https://doi.org/10.1007/978-3-030-38784-6_2 
surrounding society) the detailed analysis relevant to whether a specific economic proposal was wise.

For example, two people could embrace the same normative framework, the same broad study of society and the same economic/political philosophy (say a commitment to a market economy) and still disagree about whether the detailed analyses of raising the minimum wage have shown that doing that helped or hurt poor people. Some economists have argued that the overall impact of raising the minimum wage is to disadvantage poor people. The majority of economists have argued that the impact of raising the minimum wage helps more poor people than it harms. It is important to understand that the disagreement is not about normative values, a broad study of society or political philosophy, but about detailed economic analysis about the actual impact on poor people of raising the minimum wage.

Every person's normative framework has a profound impact on his or her concrete economic decisions. For example, Princeton philosopher Peter Singer, Karl Marx, and traditional Christians have held very different views of the nature of persons and justice. In our highly pluralistic society, people hold different, often contradictory views on all the important normative judgments that shape one's approach to economic and political judgments. Today's radical pluralism makes political decisions in a democratic society much more difficult than if everyone shared the same normative framework.

Obviously, it would be very useful if there were some neutral source for a normative framework that everyone shared. Long ago, Alexis de Tocqueville claimed that "without ideas in common, no common action would be possible .... For society to prosper, it is essential that all minds of the citizens should always be rallied and held together by some leading ideas." 1

John Rawls (perhaps the most influential political philosopher in the last three decades of the twentieth century) used to claim in his famous book, A Theory of Justice (1971) that his method offered a perfectly neutral starting point free of any specific definition of disputed claims about the good. But critics correctly pointed out that Rawls assumed a particular

${ }^{1}$ Democracy in America, quoted in Lawrence E. Adams, Going Public: Christian Responsibility in a Divided Nation (Grand Rapids: Brazos, 2002), 67. 
(and not universally accepted) view of persons. ${ }^{2}$ And in his later writings, Rawls acknowledged that every person operates with some understanding of the good grounded in that person's most basic religious or philosophical beliefs. ${ }^{3}$ There is simply no neutral source for a normative framework. ${ }^{4}$

How then shall we proceed given two indisputable realities: (1) as I have illustrated briefly in the preceding paragraphs, a normative framework is an essential component of every economic/political judgment and (2) in our radically pluralistic society, there is no normative framework shared by all or even most citizens. The only acceptable possibility in a free society is to acknowledge this pluralism and invite every citizen to articulate and promote an economic and political agenda that is shaped significantly by each person's deepest religious/philosophical beliefs. Then a democratic society uses free debate and a secret ballot to select legislators who decide what at a specific moment will be legislated. That means that every citizen-whether Hindu, Muslim, atheist, Jew, and Christian-is welcome to propose public policies that are grounded to some significant extent in that person's personal religious/philosophical beliefs.

I am an evangelical Protestant Christian-no, not the Jerry Falwell, Franklin Graham pro-Trump kind (but explaining that would require another lecture!). As an evangelical Christian, I seek to derive my normative framework to some extent from reason, tradition, and experience. But the most basic source for my normative framework comes from the biblical canon of Old and New Testaments. Obviously, when I seek to persuade people in our highly pluralistic society to adopt my proposals on economic justice, I do not normally quote biblical texts. I seek to use language and offer arguments that are understandable and (hopefully) persuasive for people with many different religious/philosophical beliefs. But

\footnotetext{
${ }^{2}$ For a critique of Rawls see Raymond Plant, Politics, Theology and History (Cambridge: Cambridge University Press, 2001), 331-347; Michael Sandel, Liberalism and the Limits of Justice (Cambridge: Cambridge University Press, 1982), 62-64; and Ashley Woodiwiss, 'Rawls, Religion, and Liberalism,' in Thomas W. Heilke and Ashley Woodiwiss, eds., The Re-Enchantment of Political Science (Lanham: Lexington Books, 2001), Chapter 3.

${ }^{3}$ See the discussion in Ronald J. Sider, Just Politics: A Guide for Christian Engagement (Grand Rapids: Brazos, 2012), 22.

4 "Natural law" advocated by many Catholics makes a similar claim to offer a neutral starting point. See my critique in ibid., 21.
} 
that does not change the fact that the normative framework that shapes my economic proposals comes from the biblical canon.

In this paper, therefore, I will seek first to define key biblical norms that shape my thinking about economic life and then second, show how I develop an economic/political philosophy which hopefully flows both from these key biblical norms and also my careful study of society generally and economics in particular.

Four normative issues are especially important: the nature of persons; the shape of justice; God's special concern for the poor; and the role of government.

First, the nature of persons. The first chapter of the Bible declares that persons-every person!-is created in the very image of God. Human beings are the only part of the created order that the Bible declares to bear the divine image. The creation story also makes it clear that the responsibility for (stewardship of) the rest of the creation which flows from bearing the image of God means that persons must lovingly watch over and care for (Genesis 2:15) the rest of creation. Precisely because every person-no matter how rich or poor, young or old, weak or strong-is created in the image of God, the law and the prophets in the Old Testament spell out how God wants every person to be treated.

The incarnation underlines even more powerfully the worth and value of every individual. Christians believe that the Creator of the galaxies became a human being - thus demonstrating in a powerful way that being human involves an immeasurably great dignity. Furthermore, the Incarnate One demonstrated a special concern for children, lepers, despised Samaritans, oppressed women-thus teaching that every individual person-even the most marginalized-is immeasurably valuable. Furthermore, Christians believe that Jesus died to offer salvation to every human being. Christians also believe that every single person is invited to live forever with the Risen Lord. Biblical teaching affirms the value, dignity, and worth of every person in a profoundly deep way.

But the biblical view of persons also has a crucial communal side. Contrary to modern thinking (deeply shaped by John Locke), persons are not isolated individuals whose essential purpose is self-fulfillment. Every person is made in the image of the Triune God-who Christians believe, is three persons in one substance. Because persons are created in the image of the divine triune community, they only reach the fulfillment intended by their Creator when they are living in right relationship with their neighbors. Neither Testament describes salvation only as a personal, 
individual relationship with God. One central aspect of salvation in both the Old and New Testaments is a new kind of visible social community. In the Old Testament that meant economic arrangements shaped by justice. In the New Testament, that means the rich sharing dramatically with the poor; that means men accepting women in astonishingly new ways; that means masters treating slaves as persons; and that means Jews and Gentiles overcoming the worst racial hatred in the ancient world.

The biblical understanding of persons transcends both the radical individualism of contemporary Western culture and the excessive communalism of both traditional cultures and communistic societies. Biblical faith affirms both the profound dignity and freedom of every person and also our need for wholesome, just community. That biblical understanding will significantly shape my view of the best economic framework.

One other aspect of the biblical view of persons is very important. Created good, persons have rebelled against God and the result is deeply selfish persons and unjust social structures. Because of this profound selfishness that inclines every person to use any power they possess for selfish advantage, all human institutions must be structured to avoid centralized, unchecked power.

Second, a biblical understanding of justice. Much modern Western thought believes that justice is merely a subjective feeling. Whereas biblical faith teaches that public law should reflect a divine standard of justice, many contemporaries argue that human laws are merely human products designed by the powerful for their own self-interest (often, in fact that is what happens!). Again and again, the Bible says God loves justice, reveals the essential shape of genuine justice, and demands that God's people promote justice.

One of the great debates of the twentieth century was whether justice is only procedural or also distributive. Does justice refer only to whether the procedures (e.g., the judicial systems) are fair or does justice also refer to outcomes (i.e., whether the distribution of land, income, health care, etc.) is fair? Political philosophers like Robert Nozick argued for an exclusively procedural view. If the procedures are fair, the outcome is just regardless of the distributive outcome. ${ }^{5}$

The two key Hebrew words for justice are mishpat and tsedaqah. Frequently, these words are translated as "justice" and "righteousness," but

\footnotetext{
${ }^{5}$ See the discussion of Nozick in Karen Lebacqz, Six Theories of Justice (Minneapolis: Augsburg, 1986), 51-55.
} 
they both refer to right relations in the socio-economic order. Examination of their use demonstrates that they refer to both procedural and distributive justice. The words certainly refer to unbiased courts that render impartial justice to rich and poor (e.g. Leviticus 19:15; Deuteronomy 1:17-19). Equally clearly, the same words are used to demand distributive justice-i.e. economic justice where everyone has access to economic sufficiency (e.g. Isaiah 5:7-9; Amos 5:11-12; Micah 2:2; 6:8). Often too, the words refer to a restorative process that delivers people from economic oppression. 6

The Old Testament discussion of the distribution of the land in Israel provides crucial insight into the content of the biblical understanding of distributive justice. Since Israel was an agricultural society, land was the basic resource needed to create wealth and enjoy an adequate economic existence. Israel was different from surrounding societies. In Egypt, the pharaoh or the temples owned most of the land. In other Near Eastern societies, a feudal system existed where the king granted a few people large tracts of land worked by landless laborers.

According to Joshua 18 and Numbers 26, each Israelite family received their own land when Israel moved into the land of Canaan. ${ }^{7}$ After a scholarly study of Israel in the time of the judges, Norman Gottwald concluded that Israel at that time was a relatively egalitarian society of small landowners. ${ }^{8}$ The Old Testament also contains measures that if followed would prevent the accumulation of most of the land in a few hands. Leviticus 25 prescribes that no matter why families lost their ancestral land, they should receive it back at the fiftieth year of Jubilee.

The prophetic writings, however, make it very clear that in the period of the kings, many people lost their land as the kings and their close associates accumulated vast holdings. In fact, the prophets declare that this economic injustice so angered God that God sent the nations of Israel and then Judah into captivity. But the prophets also looked ahead to a

\footnotetext{
${ }^{6}$ The vast number of texts that speak of God's special concern for the poor also underlines the fact that in the biblical framework, justice includes a major distributive component. See further Sider, Just Politics, 81-90.

${ }^{7}$ Whether or not these texts reflect actual history, they reveal the Old Testament's socio-economic ideal.

${ }^{8}$ The Tribes of Yahweh: A Sociology of the Religion of Liberated Israel 1250-1050BCE (London: SCM Press, 1979).
} 
future Messianic time when all persons would again enjoy their own land free of fear that powerful people would seize it (Micah 4:4). ${ }^{9}$

An important criterion of economic justice emerges from this biblical discussion of the land in Israelite society. Land is the basic capital in an agricultural society. And the biblical ideal for the land is not that the king or a few wealthy people own all the land, but rather that every family has their own land. The basic principle is that God wants every person and family to have access to the productive resources so that if they act responsibly, they can earn an adequate income and be dignified members of their community. Obviously, in our information society, knowledge is the most important capital. Therefore, applying this principle of economic justice to contemporary society means, especially (although not exclusively) that every person must have access to an excellent education.

Third, a special concern for the poor. One of the most frequent themes in the biblical canon is that God has a special concern for the poor and that God's people must do likewise. There are literally hundreds of verses on this theme in the Bible. God acts in history to lift up the poor and oppressed (Deuteronomy 26:5-8). God so identifies with the poor that being kind to the poor is like making a loan to God (Proverbs 19:17). God casts down both those who get rich by oppressing others and also people with abundant resources who simply fail to share (e.g. James 5:15; Ezekiel 16:49-50). Indeed, biblical texts even say that no matter what one's religious words or sacred activities, religious people who neglect the poor are not really God's people at all (e.g. Amos 5:21-24). Jesus even said that those who do not feed the hungry and clothe the naked depart eternally from the Living God (Matthew 25:41). ${ }^{10}$

God measures societies in part by what they do to the poorest, weakest and most marginalized. A vigorous emphasis on empowering poor people must be a central part of any biblically shaped approach to economics.

Fourth, the role of government. The Old Testament repeatedly prescribes a role for the king to promote economic justice. A text about Solomon uses the two key Hebrew words for justice to describe the king's role: The Lord "has made you king to maintain justice and righteousness"

\footnotetext{
${ }^{9}$ For a fuller discussion of the Old Testament material on the land, see Sider, Rich Christians in an Age of Hunger, 6th ed. (Nashville: W Publishing, 2015), 72-80 and Sider, Just Politics, 90-96.

${ }^{10}$ For an extended treatment of this topic, see my Rich Christians in an Age of Hunger, 45-69.
} 
(1 Kings 10:19). God was pleased with King Josiah because "he defended the cause of the poor and needy" (Jeremiah 22:15-16). We have seen that Leviticus 25 called for every family to receive back its ancestral land at the fiftieth year of Jubilee. And Deuteronomy 15 prescribed the forgiveness of debts every seven years. Neither text in any way suggests that forgiving debts in the seventh year or returning a family's ancestral land on the fiftieth year was a voluntary optional act that persons were free to practice or ignore. Presumably, the rulers were supposed to implement these laws.

Nehemiah 5 contains a striking example of governmental redistribution of economic resources. Nehemiah the governor learned that during a famine, rich powerful Jews had oppressed poor Jews. Poor Jewish people had mortgaged their land to buy food and eventually lost their land. Other poor Jews sold their children into slavery. Furious, Nehemiah the ruler called a general assembly and denounced the powerful oppressors. "Give back to them immediately their fields, vineyards, olive groves and houses, and also the interest you are charging them" (Nehemiah 5:11). And Nehemiah demanded that the rich take an oath to keep their promises. Nehemiah did not even wait for the next Jubilee to demand the return of ancestral land. As the Governor (i.e. the head of the government), he implemented economic justice which meant everyone having access to the productive resources. There is simply no biblical basis for a libertarian philosophy that states that government should play no role in promoting economic justice.

In order to arrive at some clarity on what shape I believe economic life should have today, I seek to combine my normative framework (derived as carefully as possible from the biblical canon) with a careful study of society using the tools of economics, history and politics.

\section{Private OWnership, a Market Economy AND the Decentralization of Power}

Probably the greatest economic debate of the twentieth-century raged between those supporting a socialist/communist approach and those favoring a capitalist/free-market economy. In the first model, the state owns most or all of the means of production and government agencies set wages, prices and production levels. (A central planning office in Moscow set millions of prices each year.) In the second model, private persons own the bulk of the means of production and supply and demand determines most prices and wages. 
Both biblical norms and the experience of the last one-hundred years underline the weaknesses of the first model.

A biblical normative framework raises serious questions about a stateowned, state-controlled economy. The biblical view of persons suggests that God creates each person to be a co-worker with God in shaping the material world. That calling is undermined if a few people make all the important decisions. Furthermore, from the Ten Commandments' prohibition against stealing to Jesus' call to his disciples to make loans to the poor, the Bible seems to affirm the virtue of private property-although it also makes clear that the God who demands economic justice for everyone is the only absolute owner (Leviticus 25:23). The principle that in a sinful world, people with unchecked central ized power will almost certainly use that power to oppress others also points to the importance of private property. Widespread private ownership fundamentally decentralizes power. On the other hand, when the state owns and controls all productive assets, then economic and political power are highly centralized.

The experience of the last hundred years demonstrates that the communist model has huge negative results. The unchecked power of communist political leaders resulted in the loss of freedom (religion, speech, assembly) as the state sought to, and largely succeeded in, controlling every sector of society. It also resulted in the channeling of vast special privileges to a tiny party elite-in contradiction of the communist egalitarian ideal. It is no accident that societies with widespread private ownership enjoy higher levels of freedom than societies where the state owns most or all of the means of production. Widespread private ownership decentralizes power in a way that makes it much more difficult for political leaders to dominate all of society for their selfish advantage.

Furthermore, the communist model proved to be less economically efficient. No group of bureaucrats in a central office knows enough to wisely determine prices and levels of production for a whole society. The market mechanism of supply and demand simply works better. That is substantially why China experienced explosive economic growth after the Chinese government increasingly embraced major aspects of a free-market economy after 1979 . 
I conclude that both biblical norms and historical experience indicate that a largely privately owned economy where supply and demand determine most wages and prices is the preferred economic model. ${ }^{11}$ And the fact that widespread adoption of this economic model has contributed greatly to a dramatic drop in global poverty means that on balance the poor of the earth have benefited. Tens of millions of very poor people in South Korea and Taiwan and more recently many hundreds of millions of very poor people in China, India, Indonesia, and elsewhere are no longer poor in part because their nations embraced important aspects of a market economy.

But that in no way means that today's market economies have no problems when judged by a biblical normative framework.

For one thing, the ideal assumed by market-economy theorists seldom or ever exists. Ideally, both consumers and potential competitors have full information, monopolies do not exist, and there are no externalities. But in real life advertising manipulation and monopolies often work to promote excessive benefits to a few.

Second, at least one-quarter of the world's people do not enjoy what the biblical economic norm demands-access for everyone to the productive capital needed to earn an adequate living. Vast numbers of people have virtually no capital. They have no land, almost no money and extremely little or very poor education. A market-economy simply supplies what the people with capital demand. It allows the others to die of starvation or disease.

Third, in recent decades, capitalist societies have seen vast concentrations of income and wealth in small elites. In the United States, the richest $1 \%$ own more wealth than the bottom $90 \% .{ }^{12}$ In recent years, more than $90 \%$ of all the growth in national income has flowed to the richest one percent. ${ }^{13}$ Income inequality is greater today than at any time since just before the Great Depression. ${ }^{14}$

${ }^{11}$ For a longer discussion of these issues, see Sider, Just Politics, 113-115 and Sider, Rich Christians in an Age of Hunger, 147-156.

${ }^{12}$ See Christopher Ingraham in the Washington Post, December, 2017.

${ }^{13}$ According to Josh Barro in Business Insider, September 12, 2013. See also the data cited in my Fixing the Moral Deficit (Downers Grove: InterVarsity, 2012), 26.

${ }^{14}$ See Chad Stone et al., "A Guide to Statistics on Historical Trends in Income Inequality," Center for Budget and Policy Priorities, February 16, 2018, https://cbpp. $\mathrm{org} / \mathrm{research} /$ poverty-and-inequality/a-guide-to-statistics-on-historical-trends-in-incomeinequality. 
Why is that a problem? Not because making a great deal of money from a new invention that benefits many people is bad (It is not). Nor because the biblical norm is equality of income and wealth (It is not). But both the biblical doctrine of human selfishness and human history warn that centralized power will be used for the selfish advantage of the few.

How much economic inequality is acceptable and when does it become destructive to the rest of society? Neither the biblical canon nor historical wisdom provide any precise mathematical answer to that question. But at least one fundamental principle is relevant. One crucial aspect of economic justice is that everyone must have access to the productive assets so they can earn an adequate living. That means that whenever the extremes of wealth and income make it difficult or prevent some people from having access to adequate productive capital, or prevent society from caring for the young, old and disabled who cannot care for themselves, that inequality is wrong and must be corrected. An increase in economic inequality that harms the poorer members of society and hinders their opportunity to gain access to adequate, productive capital is unjust. Lord Acton's dictum that power corrupts and absolute power corrupts absolutely underlines this point.

I would argue that the extremes of income and wealth in the United States today have reached that point. The New York Times reported on October 10, 2015, that almost one-half of all the campaign contributions for the presidential candidates from both parties had come from just 158 extremely wealthy families. Is it surprising that many powerful politicians promote policies that both provide huge tax cuts to the richest Americans and also would cut food stamps and health coverage for poorer Americans? And these same politicians refuse to vote for adequate funding to provide quality educational opportunity for millions of poor, minority, inner-city children. Clearly, the high concentration of wealth is undermining the opportunity for poorer Americans to acquire adequate nutrition, health care, and the capital to become self-sufficient.

Interestingly, some economic studies seem to show that great economic inequality is also harmful to the economy. A study by the International Monetary Fund suggested strongly that the sharp increase in economic inequality just before the Great Depression (starting in 1929) and the Great Recession (starting in 2007) contributed significantly to both 
economic disasters. Another study showed that a decrease in inequality produces substantial economic growth. ${ }^{15}$

A fourth problem with today's market economies is that they are creating dangerous environmental changes that will very likely impose huge costs on future generations. Unfortunately, markets pay little attention to future generations. The market fails to account for the "externality" of environmental pollution.

These problems with today's market economies can be fixed. But that will require the right kind of governmental action. The libertarian notion that government has no role in empowering poor people and that all we need to overcome poverty is a totally laissez-faire market-economy contradicts both biblical teaching on the role of government and the historical experience of countries like South Korea and Taiwan. Earlier, we saw that the Bible describes a significant role for government to empower poor people. And careful study of countries like South Korea and Taiwan show that their economic "miracles" were the result of the adoption of a market economy along with the right kind of governmental activity.

In South Korea, economic growth started around 1952. Governmental action increased the percentage of farmers who owned their own land from 50 to $94 \% .{ }^{16}$ Something similar happened in Taiwan. In addition, the governments in both countries invested heavily in health, education and job training. An activist government was central to the economic explosion in both nations. Nobel laureate economist Amartya Sen stresses the importance of the right kind of government action. "In the past of the rich countries today we can see quite a remarkable history of public action, dealing, respectively, with education, health care, land reforms and so on." 17

${ }^{15}$ Michael Kumhof and Romain Rancière. "Leveraging Inequality," Finance and Development, 47, no. 4 (2010), 28-31; Andrew G. Berg and Jonathan D. Ostry. "Equality and Efficiency," Finance and Development, 48, no. 3 (2011). www.imf.org/external/pubs/ $\mathrm{ft} /$ fandd/2011/09/berg.htm. See also, Joseph E. Stiglitz, The Price of Inequality. New York: Norton 2012, especially Chapter 4.

${ }^{16}$ United Nations, Human Development Report 1993, 30. New York: UNDP, 1993.

17 Development as Freedom (New York: Knopf, 1999), 143. See also Abhijit Vinayak Banerjee and Esther Duflo, Poor Economics: A Radical Rethinking of the Way to Fight Global Poverty, 46-58, 81-104, 394-401 (New York: Public Affairs, 2011). 
I can sketch only very briefly how my economic/political philosophy (grounded I hope in a normative biblical framework and a careful - as unbiased as possible! — study of the best societal research by economists, sociologists, historians, etc.) leads me to more specific contemporary judgments about economic and political life. But here are a few examples.

Government has a significant role to play in promoting economic justice but government must remain limited. Government rightly designs educational systems that promote quality education for every child. Generous Pell grants that enable children from poor families to achieve a college degree creates not dependency but self-sufficiency for a life timeand therefore acts as a just measure of economic redistribution. Because every person is created in the image of God, society (family, religious institutions, non-governmental agencies, and government) should guarantee that everyone has access to quality health care, basic food and housing. Whenever other institutions are unable to provide necessary resources, government rightly acts to prevent hunger, insufficient health care, inadequate housing, etc. But always, government activity must be shaped in a way that nurtures self-sufficiency, not dependency. And it must strengthen, rather than undermine, non-governmental institutions like family. (For example, a welfare policy that undermines rather than strengthens stable two-parent families is misguided.) The earned income tax credit (which both reduces poverty and rewards work and responsibility) illustrates the right kind of government-mandated promotion of economic justice. Tax policies (like the graduated income tax) that require that richer members of society pay taxes at higher levels than poorer people rightly provide the funds to promote economic redistribution that offers everyone access to productive resources. It also tends to prevent a dangerous concentration of wealth in just a few hands. Able-bodied people have a moral obligation to work responsibly and society has a responsibility to provide jobs that pay a living wage to all who do work responsibly.

The reality of human selfishness means that unchecked, centralized power is always dangerous. That is one important reason why government policy should always seek to strengthen rather than undermine nongovernmental institutions. That is also why governmental policy should support strong (democratically run!) unions because unions rightly offer a counterweight to otherwise unchecked corporate power. 
Always, government policy should seek to empower the poorer members of society. Every legislative proposal should be evaluated in part on what is its likely effect on the poorest.

Obviously, applying my economic/political philosophy to any specific issue in any specific society is a complex task. There is no mathematical formula for determining when a specific legislative proposal properly balances the role of governmental and non-governmental institutions. Or when specific legislation would result in excessive centralized governmental power. Or what kind of governmental action is needed to prevent a few non-governmental institutions (e.g. banks, private corporations) from consolidating massive unchecked power. Prudential wisdom and genuine dialogue with those who disagree and present conflicting data are essential.

The mere fact that a Christian seeks to ground her economic/political agenda in a normative biblical framework and careful, factually grounded study of society does not guarantee that her concrete proposals will be wise and effective. Unforeseen consequences regularly occur. But a persistent commitment to improving one's understanding of both biblical norms and the best factual data provides an excellent foundation for improving one's concrete agenda. If one starts with the belief that every person, no matter how poor or weak, is created in the image of God and is therefore inestimably precious; that justice demands systems that empower people with few resources to have access to the capital to earn a good living; that God's special concern for the poor means that God and God's people measure societies especially by what they do to the poor; and that government properly acts to redistribute resources in effective ways that empower poor people; if one starts with this set of normative commitments, then one will support effective programs that empower poorer members of society and reduce dangerous extremes of income and wealth. Always, of course one will have to evaluate concrete programs designed to reach these goals to determine whether they are effective and if effective, whether they are the most effective ways to reach these goals.

\section{BIBLIOGRAPHY}

Adams, Lawrence E. Going Public: Christian Responsibility in a Divided Nation, 67. Grand Rapids: Brazos, 2002.

Banerjee, Abhijit Vinayak and Esther Duflo. Poor Economics: A Radical Rethinking of the Way to Fight Global Poverty, 46-58, 81-104, 394-401. New York: Public Affairs, 2011. 
Berg, Andrew G. and Jonathan D. Ostry. "Equality and Efficiency." Finance and Development 48, no. 3 (2011). www.imf.org/external/pubs/ft/fandd/ 2011/09/berg.htm.

Gottwald, Norman. The Tribes of Yahweh: A Sociology of the Religion of Liberated Israel 1250-1050BCE. London: SCM Press, 1979.

Kumhof, Michael and Romain Rancière. "Leveraging Inequality." Finance and Development 47, no. 4 (2010): 28-31.

Lebacqz, Karen. Six Theories of Justice, 51-55. Minneapolis: Augsburg, 1986.

Plant, Raymond. Politics, Theology and History, 331-347. Cambridge: Cambridge University Press, 2001.

Sandel, Michael. Liberalism and the Limits of Justice, 62-64. Cambridge: Cambridge University Press, 1982.

Sen, Amartya. Development as Freedom, 143. New York: Knopf, 1999.

Sider, Ronald J. Just Politics: A Guide for Christian Engagement, 22. Grand Rapids: Brazos, 2012.

Sider, Ronald J. Fixing the Moral Deficit, 26. Downers Grove: InterVarsity, 2012.

Sider, Ronald J. Rich Christians in an Age of Hunger, 6th ed., 72-80. Nashville: W Publishing, 2015.

Stiglitz, Joseph E. The Price of Inequality. New York: Norton, 2012.

Stone, Chad et al. "A Guide to Statistics on Historical Trends in Income Inequality." Center for Budget and Policy Priorities, February 16, 2018. https://cbpp.org/research/poverty-and-inequality/a-guide-tostatistics-on-historical-trends-in-income-inequality.

Open Access This chapter is licensed under the terms of the Creative Commons Attribution 4.0 International License (http://creativecommons.org/licenses/ by $/ 4.0 /)$, which permits use, sharing, adaptation, distribution and reproduction in any medium or format, as long as you give appropriate credit to the original author(s) and the source, provide a link to the Creative Commons license and indicate if changes were made.

The images or other third party material in this chapter are included in the chapter's Creative Commons license, unless indicated otherwise in a credit line to the material. If material is not included in the chapter's Creative Commons license and your intended use is not permitted by statutory regulation or exceeds the permitted use, you will need to obtain permission directly from the copyright holder.

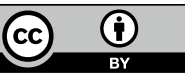




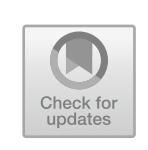

\title{
Biblical Stewardship and Economic Progress
}

\author{
Anne Ratbbone Bradley
}

\section{InTroduction God’s Design ANd Desires}

This paper will be an exploration into the design and desires of God which are revealed to us in the story of creation. When society is constructed in ways that allow human beings to work and unleash their human creativity in God-pleasing ways, human flourishing is advanced. When society is not ordered in ways that both respect the desires of God and the objective realities of creation human flourishing is hindered and stunted. There is a path to human flourishing that requires specific institutions and must respect the principles and realities that economics helps illuminate.

This paper will examine those economic realities from the whole scope and comprehensive narrative of scripture to understand how we can better advance human flourishing around the world. We will begin with a theological attempt to understand God's design and desires for us and his creation, which reveals his purposes and ours. The paper will then discuss how understanding our purpose requires that we live out our purpose which is ordained through our creation (imago dei) through our human creativity as it is applied to nature. The transformation that occurs allows us to fulfill God's creation mandate as it is revealed in Genesis. We then

\footnotetext{
A. R. Bradley $(\bowtie)$

Academic Director, The Fund for American Studies, Washington, DC, USA

(C) The Author(s) 2020

T. Akram and S. Rashid (eds.), Faith, Finance, and Economy, https://doi.org/10.1007/978-3-030-38784-6_3
} 
will assert a biblical perspective of stewardship: oikonomia-prudent stewardship of the gifts and talents which God has endowed each of us with for the purposes of work with the goal of value creation which allows us to make contributions to shalom, or flourishing. The paper will define flourishing theologically and then present the Austrian school of economic thinking as it was particularly developed by Ludwig von Mises and F. A. Hayek as detailing a political economy that is most in line with a world where individuals can pursue and obtain biblical human flourishing.

The creation account detailed in Genesis gives us the divine context for our existence. We are not here by chance. We are formed by the creative imagination and hand of God, made in his image and likeness (Genesis 1:25-28). We are here precisely because God put us here. This reality instills great dignity, purpose, and immeasurable value within us. Genesis 1:25-28 informs us both about the nature of God and the nature of mankind:

God made the wild animals according to their kinds, the livestock according to their kinds, and all the creatures that move along the ground according to their kinds. And God saw that it was good. Then God said, "Let us make mankind in our image, in our like- ness, so that they may rule over the fish in the sea and the birds in the sky, over the livestock and all the wild animals, and over all the creatures that move along the ground." So God created mankind in his own image, in the image of God he created them; male and female he created them. God blessed them and said to them, "Be fruitful and increase in number; fill the earth and subdue it. Rule over the fish in the sea and the birds in the sky and over every living creature that moves on the ground."

What does it mean to be created in God's image? In Systematic Theology, Wayne Grudem points out that the words used in Genesis 1:26-27, "image" (tselem) and "likeness" (demut), in the Hebrew "refer to something that is similar but not identical to the thing that it represents or is the 'image' of." Genesis 1:26 "would have meant to the original readers, 'Let us make man to be like us and to represent us."'l

The Hebrew root of the Latin phrase for image of God-imago Deimeans image, shadow, or likeness of God. At the very least, this means humans occupy a higher place in the created order because we alone are

${ }^{1}$ Grudem, Wayne A. Systematic Theology: An Introduction to Biblical Doctrine. Grand Rapids: Zondervan, 1994. 
imprinted with god-like characteristics. Even more so, imaging God is a central aspect of our fundamental created order. To be fully human is to reflect God's creative, spiritual, intelligent, communicative, relational, moral, and purposeful characteristics. ${ }^{2}$ By realizing our gifts to their utmost potential, we are most obedient to God's design.

Human existence is a special, authoritative indicator of the creative power of God. God created man out of nothing (ex nihilo). He is a maker, an author, a creator, and a worker. We harbor an aspect of this creative ability in our capability to create something out of what God has already given us. Only God can create something out of nothing, but by forming us in his image, we can create value from and improve upon his creation. We are commanded to do nothing less. Not only do we reflect God's characteristics, but as his image-bearers, we have specific duties to fill. We are the only creatures commanded to fill the earth and subdue it, and to have dominion over all of creation (Genesis 1:28). We roam the earth with all of God's creatures, but we also rule the earth and God's creatures. God created us with the capability and the responsibility to reign over his earthly creation.

Understanding the implications of being made in the image of God is the first step. Fully appreciating the context of our creation helps foster great personal fulfillment because it brings awareness to God's intentional design of and desires for his creation.

God is unique and as image-bearers we too are unique. We bear similar characteristics, yet we are all different in talents, gifts, abilities, attitudes toward risk, subjective preferences and creative capacities. It is God's intentional design for no two humans to be the same. Our distinct uniqueness points to God's infinite power and gives us purpose. Humans are the crowning splendor of God's hand (Isaiah 62:3). Not only does God create us all differently, but he also gives each person a specific purpose. Each of us is his unique workmanship for the role he designed specifically for us to play (Ephesians 2:10). The role we have in the kingdom of God is one that no one else can occupy. Each role in the kingdom is vital. There is no role that is more important than another because God has woven all things together for his purposes-just like the

${ }^{2}$ Staub, Dick. "What Made in the Image of God Really Means." Relevant, March 4, 2013. http://www.relevantmagazine.com/god/deeper-walk/features/23549-qmadein-the-image-of-godq. 
intricate working of the human body. Paul explains this in I Corinthians 12:5-7:

There are different kinds of gifts, but the same Spirit distributes them. There are different kinds of service, but the same Lord. There are different kinds of working, but in all of them and in everyone it is the same God at work. Now to each one the manifestation of the Spirit is given for the common good.

We are made in the image of God, but we do not have the same capacity or power or holiness as God does, so we face limitations. This was true before the fall of man. We each have twenty-four hours in a day and limited means and knowledge to accomplish everything we desire. This was true before our sin, and it is true and exacerbated after our sin. Adam and Eve had to tinker and learn and think and develop skills. They were finite just as we are.

Our limitations are the reason we must come together through economic exchange if we want to make kingdom-building contributions to the common good using our creativity: we cannot do that in isolation. We will all surely perish if WE can only rely on ourselves or even a small circle of people. If we must figure out how to produce all the things we need and desire, we are left with little and so are others. However, if we, through community, have the space to cultivate and develop our skills, we can learn and improve and then are better able to serve others. That community is brought together through exchange and allows us to fulfill God's desires for his creation.

Integrated into creation is a great truth of the created universe that is often overlooked. The word that best describes God's creation is interdependence. From the very beginning, a distinct connectedness has tied all of creation together. Before sin entered the world, everything worked together in perfect harmony. Today, we still witness the interconnectedness of creation, even though it is fraught with the frustration of sin. Despite sin, we know that God is working all things together for good for those that love him and have been called according to his purpose (Romans 8:28-30). We are here to fulfill God's purposes, which he has predetermined from before the beginning of time. 


\section{Purpose And Creativity}

On the sixth day of creation, when God declared it "very good," all the necessary elements were present to work together for his purposes. There is an explicit, observable, and intentional way that all these things work together.

They function, operating in harmony, beauty, grandeur, and abundance. When God's creation works in the integrated and harmonious way in which it is intended, it points back to God and glorifies him, shalom is the result. Shalom is a word that is often translated as "peace" or the absence of conflict, but it has a much richer meaning. Shalom means universal flourishing, wholeness, and delight. It is the way things ought to be. The Old Testament prophets pictured shalom as the wolf living with the lamb, weapons turned into farming tools, deserts blooming, and the mountains streaming with red wine (Isaiah 2:4, 11:6; Ezekiel 36:35; Amos 9:13).

Each element of creation has an interconnection with all the other elements. Humans reflect something different about God's creation. We can reason, think, and decide between many alternatives. We do not strictly operate out of instinct. We are here to do much more.

God would not give us the garden and tell us to cultivate it without giving us the tools we need. In Genesis 2, God continues by giving us our marching orders and our mission. Humans have a special role in the cultivating of God's very good creation. We learn more about this in Genesis 2:15: "The Lord God took the man and put him in the Garden of Eden to work it and take care of it."

This is our mission as thinking and reasoning human beings made in God's image. We are to do two fundamental things: work his garden and take care of it. To take care of something requires putting work into it and protecting it from destruction. If God asked us just to take care of his garden, we would not alter it. One could imagine that we would stand watch and make sure it remains as is; we would preserve it. In caring for the garden, we might prune it, but we would not be "working it" in the way God asks us. The word "work" in Hebrew as used in Genesis 2:15 is the verb abad, which means "to work or to serve." 3 God explicitly asks us to work his creation and serve him. He tells us to "be fruitful and increase

3 "Strong's Hebrew: 5647. עב ד. (abad)-To Work, Serve." http://biblehub.com/ hebrew/5647.htm. 
in number; fill the earth and subdue it" (Genesis 1:28). God desires us to multiply, prosper, cultivate, and enjoy his good creation. This is our ultimate purpose, also known as the cultural mandate.

\section{SHALOM AND FLOURISHING}

With all the diversity across humanity over thousands of years, one might not expect to find many unifying ideas. Remarkably, there seems to be one meta-concept that transcends all worldviews. Jonathan Pennington writes:

This concept has staying power and universal voice because it addresses what is most basic and innate to all of humanity, despite the diversity of race, culture, and values. It is a concept that proves to be the motivating force and end goal of all that humans do and think. This idea or theme can be identified as human flourishing ... The desire for human flourishing motivates everything humans do...All human behavior, when analyzed deeply enough, will be found to be motivated by the desire for life and flourishing, individually and corporately. ${ }^{4}$

While no two humans are the same, all hearts have the same intrinsic desire. We are all created in the image of God with the desire to know him, to flourish, whether we acknowledge this or not. It is a universal truth that has been written on our hearts. It is part of our nature and our design, and as such it transcends trends and culture. Ecclesiastes 3:11 says: "He has made everything beautiful in its time. He has also set eternity in the human heart; yet no one can fathom what God has done from beginning to end."

The desire to flourish is written deep within our souls.

This idea of human flourishing is the Old Testament Hebrew concept of shalom mentioned previously. Cornelius Plantinga in his book, Not the Way It's Supposed to Be, defines shalom as: "The webbing together of God, humans, and all creation in justice, fulfillment, and delight...

\footnotetext{
${ }^{4}$ Pennington, Jonathan. "A Biblical Theology of Human Flourishing." The Institute for Faith, Work \& Economics, 2015. http://tifwe.org/resources/a-biblical-theology-ofhuman-flourishing-2/.
} 
Shalom means universal flourishing, wholeness, and delight ... the full flourishing of human life in all aspects, as God intended it to be."

One of the titles we see in the Old Testament for Christ is the Prince of Peace, but what the passage really says in Hebrew is that Jesus is the Prince of Shalom (Is. 9:6). Jesus is not just a prince that will come back and stop all the fighting; he is the prince who will come back and restore universal flourishing. His work as the Prince of Shalom "means complete reconciliation, a state of the fullest flourishing in every dimension-physical, emotional, social and spiritual." 6 The redemption brought by Christ is about restoring everything to the way it should be. Shalom bookends human existence. It characterizes the Garden of Eden (the way it was supposed to be) and the eternal City, the New Jerusalem (the way it is going to be), and so provides the vision for our existence in between. ${ }^{7}$

The word shalom is used approximately 250 times in the Hebrew Bible, with the majority of uses describing biblical flourishing. For example, shalom is the climax of the Aaronic or priestly benediction in Numbers 6:24-26, looking forward to the ultimate blessing from God: "The Lord bless you and keep you; The Lord make his face to shine upon you, and be gracious to you; The Lord lift up his countenance upon you, and give you shalom."

The work that God designed for us to do before the onset of time brings about greater levels of flourishing by advancing creation toward shalom, the way things were supposed to be. This happens despite our $\sin$ because God is at the helm of the redemptive process. Our sin does not change God's design or desire for his creation. Our sin just makes our job rife with frustration and sin.

Genesis reveals God's ultimate purposes: his glory and the flourishing of his creation. In this, our goal is stewardship (prudent cultivation) of all we are and all we have, all the time.

Stewardship comes from the Greek word oikonomia, which appears in the New Testament. It is a Greek compound word that is translated

\footnotetext{
${ }^{5}$ Plantinga, Cornelius. Not the Way It's Supposed to Be: A Breviary of Sin. Grand Rapids, MI: Eerdmans Publishing, 1995.

${ }^{6}$ Keller, Timothy. Generous Justice: How God's Grace Makes Us Just. New York, NY: Dutton, Penguin Group, 2010.

${ }^{7}$ Whelchel, Hugh. How Then Should We Work? Rediscovering the Biblical Doctrine of Work. Bloomington, IN: West Bow Press, 2012. Strong's Greek: 3622. oíкоvouía (oikonomia).
} 
as the "management of household affairs, stewardship, and administration." 8 We often think of the word stewardship as synonymous with tithing, church service, or missions. This is a narrow, insufficient understanding of stewardship. God cares about your decisions regarding all of your resources-time, money, skills. For our hearts to be fully committed to God's purpose, we must have a proper understanding of what God asks of us. God is not asking us to steward part of our income, talents, and time. He is asking us to steward all of it. The idea of wholeness is vital for stewardship; a whole-hearted commitment to God's purposes must fuel our interests and drive our daily purposes such that we are continually aligned with His desires.

Deuteronomy 6:4-5 gives us this command: "Hear, O Israel: the Lord our God, the Lord is one. Love the Lord your God with all your heart and with all your soul and with all your strength. This commandment is known as the Shema, which means "hear."

Theologian Scott Redd writes that wholeness is the goal of redemption in Christ. Redd states that the above verse is not about loving God "a lot"; it is about how our relationship with God should infiltrate every part of our lives. ${ }^{9}$ Jesus says that "where your treasure is there your heart will be also," so to be good stewards God must govern our heart, soul, and strength (Matthew 6:21). Our external choices follow.

Being good stewards, or whole-life stewards, can only come after God changes our hearts and we give our entire person to Christ. Only then can we change what we treasure. All our choices flow from our desires, so we must continually align our desires with God's desires. The social and economic order then must be buttressed by an ethos of creativity and respect for individual and property rights.

At its core, stewardship is about making choices, and making choices is the science of economics. Making decisions that please God is our goal as God's stewards. Every day, we must choose from many options, and each choice imposes a tradeoff and long-run consequences. Stewardship requires us to embrace the principles of economic thinking that stem from the principals of scripture and human anthropology.

\footnotetext{
${ }^{8}$ Stewardship, Administration. Strong's Greek: 3622. oikovo $\mu$ ía (oikonomia)—Stewardship, Administration. http://biblehub.com/greek/3622.htm.

${ }^{9}$ Redd, Scott. Wholehearted: A Biblical Look at the Greatest Commandment and Personal Wealth. McLean: The Institute for Faith, Work \& Economics, 2016.
} 


\section{OIKONOMIA: STEWARDSHIP AND THE ECONOMIC WAY OF THINKING}

Our sin, our finite knowledge, and our hubris make it difficult. We are constantly the victims of our own sin. Therefore, it is imperative to understand our origins; understanding how we got here and why we are here is critical for making God-honoring decisions. We have been given all the resources we need to accomplish what God asks of us. Now we must assess the necessary operating environment for success.

The parable of the talents is a helpful metaphor for what God asks of us as it relates to fulfilling his desires. Matthew 25:14-30 is important for our discussion about God's design and our role as whole-hearted stewards.

The passage of Matthew 25:14-30 is about maximizing productivity using our creativity for the purpose of creating more than what previously existed. The master asked each servant to take what they were given and care for it according to his desires, essentially, to invest his resources to make a profit. Greater profits of the individual level are a sign of good stewardship and increasing productivity. We are asked to do the same. Profit is about having something left over after one has invested time, talent, and treasure. Remember Genesis 1: God did not ask Adam and Eve to just watch the Garden of Eden; he told them to work it, to cultivate it, to make it better. We practice good stewardship by carefully, thoughtfully investing God's resources to make the most out of them.

We get closer to shalom in the here and now because we participate in bringing it about. We experience true joy when we do the very best we can with what we have been given. In addition, God rewards good stewardship with greater responsibility. There are spiritual and material rewards to good stewardship, both now and eternally.

We can also see from this text that what God gives us is directly related to how he uniquely crafted each of us. No two people are the same. We have different gifts and propensities that are manifested in unique ways. This means that we are all expected to steward in a wholehearted manner but that each of us brings different gifts to the table. Some have "five talents," some have one, but we are all endowed with creativity and we are expected to be put to the service of others and the common good.

When we put our creativity to use; we are then able to make positive contributions to human flourishing. This requires prudence, investment, an eye toward the future, a focus on problem-solving and a mechanism 
that fosters each one of us to look beyond a narrow view of our selfinterest to also serve others. All of this requires leftovers or residual assets. If we use up all our time, energy, and talent in the pursuit of mere survival; it is difficult perhaps impossible to have any residual to invest in others. It is only when we have something left over that we have more to give. Abundance is a good thing: not for its own sake but because it glorifies God. Abundance means that we have more than we need in one moment: more time, more energy, more nutrients, more talents. Leftovers provide the sustainable base for service, resourced generosity, and investment.

The costs of not doing this well are tragic. We suffer and become alienated from God, making things harder for both ourselves and others. It is because we are interdependent that the consequences of our actions are not isolated. They have ripple effects on others so there are social consequences when each individual person cannot or is restrained from fully using their talents. Leftovers give you additional opportunities to serve.

Without profit, we do not have extra to give. Profit is also a signal that we are doing a good job. When we have leftovers, we are accomplishing God's purposes. Profits along with lowered opportunity costs yield greater levels of wealth. What we require in a flourishing society is to have the appropriate incentives so that personal wealth is tied to advancing the social or common good. Profit is the mechanism which when pursued in a mutually inclusive way we are induced to be the best stewards possible given our constraints.

The market economy makes the profit signal the center of productive entrepreneurial activity and induces those entrepreneurs to find ways to discover new ways of doing things and to solve problems. The profit that is pursued within biblical parameters is objectively good. In Jeremiah's (Jeremiah 29:7) letter to the exiles he tells the exiles to "seek the peace and prosperity of the city to which I have carried you into exile: for if it prospers, you prosper." Biblical prosperity is mutual, it is inclusive and extends to all members of society. It is not exploitative or greedy or corrupt. All humans have the potential for this harmful behavior, but we need an environment that best allows us to seek mutual prosperity through the pursuit of monetary profit. We live in a world where this has been achieved by many nations to a large degree, it needs to be extended to everyone. 
There is a path of biblical flourishing, and material well-being is an aspect of that accomplishment. To do this, there are necessary requirements to which individuals and society must adhere. In this sense, economic realities must be respected and obeyed when we attempt to live in the social world.

\section{Economic Realities and Human Anthropology}

Economics is a science that studies human decision-making under conditions of radical uncertainty. Humans are finite and fallible; we try to maximize our own utility amid great ontological uncertainty. We pursue our own interests but that does not mean we know what to do or how to do it in the most productive manner. For this, we need to rely on the skills and talents of others. Our self-interest guides our choices but that self-interest can be used, under the right incentives and institutions, to serve others and generate greater societal well-being. To induce people to maximize their own value in a way that also maximizes the common good in the service of others we must also assess the requisite economic, political, and legal institutions that respect these realities.

The most accurate understanding of economics was eloquently explained by economist Ludwig von Mises in 1949 in his seminal work, Human Action. ${ }^{10}$ Mises defined economics as the science of purposeful human action. In our context, economics is the science of making God-pleasing decisions. If economics is about human action, what drives humans to act? Three things need to be in place for us to act with purpose: we experience a state of uneasiness, we have a vision for an improved outcome, and we take conscious and purposeful steps to get there. This does not imply that we engage in this process without error or sin, rather that we are purposeful and each of us takes the steps we deem appropriate to improve our conditions.

Mises understood the nature of man. He saw men not as preprogrammed atomistic robots but as flawed and finite individuals with purpose.

Human Action was written at an important time both in global history and inside the economics profession. The Bolshevik revolution occurred

${ }^{10}$ Mises, Ludwig von. Human Action: A Treatise on Economics. Auburn, AL: Ludwig von Mises Institute, 2008. 
in 1917 and the Soviet Union was under communist control. Simultaneously, some economists, such as Oskar Lange and Abba Lerner, were advocating for the superiority of socialism over capitalism. Later John Maynard Keynes, whose economic theory rested on the volatility and unpredictable nature of market economies, advocated for government intervention as a stabilizing mechanism. American economist Paul Samuelson maintained in his mainstream textbook Economics in 1961 that Soviet economic growth would surpass U.S. economic growth. He maintained this position until the 1980s, just pushing back the dates of the Soviet eclipse of the U.S. economy. That market socialism was considered feasible and that "persistent market failure" was mainstream belief made government management of the economy, in some shape or form, the widely held view through the twentieth century. Market socialism is embraced again today and some "managed planning" seems feasible and perhaps attractive. Today it is still attempted in varied forms either total economic planning which we see in modern Venezuela or attempts to mix some market operations with authoritarian control as in modern China.

Mises saw that even with the best of intentions, central planning disregarded vital elements of human nature and that human choice was contextually dependent. Humans were able to obtain higher levels of wealth and societal well-being under the institutional arrangements predicate upon prices, property rights, profit, and loss. Hayek demonstrated that under alternative institutional arrangements devoid of these characteristics, human immiseration persisted and poverty remained. Central planning advocates ignored the very elements that Mises understood as critical to human choice. To disprove that central planning is an appropriate economic order which could advance human flourishing, one must begin with the nature of human choice and the realities of humankind.

It is no accident that history proved Mises right, and 49 years after the release of Human Action, communism as the world saw it unfold in the Soviet Union failed. Its 71-year reign, which tried to divorce humans from their God-given purpose, killed millions and impoverished more. When we reflect on the language in Genesis and God's creation, we see that this was not his original desire for humankind but rather led to mass immiseration. The picture in Genesis before the Fall is one of abundance, both spiritually and materially. In contrast, the former Soviet Union as well as modern-day Venezuela or North Korea pitted man against himself by defying man's nature and, in its wake of horror, a godless and poor society worked hard for survival. 
Mises and F. A. Hayek fought the central planners intellectually in the twentieth century but they stood on the shoulders of those who have gone before including the sixteenth century School of Salamanca. It was their important theological contribution to the science and discipline of economics that paved the way for the future of market process theory. The sixteenth century School of Salamanca made reformulations of the concept of natural law and statements on the right to possess private property and benefit from the ownership of the private property. These theological contributions to the science of human action would be carried forward later to Carl Menger, the founder of the Austrian School of Economics. The resulting economic theory has extraordinary explanatory power because it begins with a proper understanding of human anthropology. People are purposeful in their actions; they desire something better and act to remedy their current conditions. From this, we can understand the everyday economic realities that confront us every time we engage in this calculus of choice.

The human action model proposed by Mises makes sense only because we must choose, and when we choose, we give up something else. We have unlimited desires but limited means to satisfy those desires. We must make choices, and when we choose, we face trade-offs that impose costs. The cost is always relative for each person and for each decision because we value things differently.

We live in a world of scarcity and we always have, even before the Fall, because we are finite. We have never had infinite knowledge or power. Sin exacerbated the conditions of scarcity by making everything more difficult. Human discovery, entrepreneurship, and learning are all more difficult than they were before sin. We still must choose, but those choices are less transparent and fraught with our own sinful desires.

Effective and whole-hearted stewardship requires that we are fully aware of our nature and our constraints and these are the realities of human action that can be divined from scripture and observation: scarcity, subjective value, self-interest, incentives, and interdependence.

The idea that we value things differently comes from our uniqueness. We subjectively value things based on our preferences and needs because we are all made with unique gifts and desires. Based on God's intentional design, we value things differently. Subjective value is a characteristic of all people because it is part of how God made us. We have different desires that work their way into what costs we are willing to bear to acquire 
certain things. Our varied subjective values result in many options that exist to serve a wide range of different tastes and preferences.

What we value is driven by our unique makeup, personal preferences, and our circumstances at the time. The world is better when there are more options at a lower cost. Having more options satisfies more preferences, lowers costs, and increases quality. As a result, we all profit more and have leftover resources and time to devote to other pursuits.

Subjective value drives our choices or our personal interests and preferences. It simply means that we each value things differently. There is no good or service that has objective value but rather, individuals assign values to things. Each of us assigns values differently based on our preferences. What we view to be in our self-interest is inextricably linked to what we prefer or value. The idea of self-interest can make believers recoil as it is often confused with selfishness. In some way, self-interest is a more benign concept; it is the mechanism of human choice. The Misesian human action model asserts that choice is motivated by discomfort. The subjective value determines the "terms" of choice, and we only choose things - out of self-interest-that we prefer over not having them.

When we dismiss the notion that our lives are all about God and we put ourselves first, our subjective value can become selfish, more focused on what we want, not what God wants. Consequently, things become more difficult for us. We again become victims of our own sin, and the things we think are good for us harm us. Self-interest then involves sacrifice or surrender of my will to God's will. The closer we get to God through prayer and reading his Word, the more we recognize the depth of our sin. Yet, we can still daily seek to surrender our lives to his will with every choice we make.

Self-interest is the mechanism of human action. What we perceive as "good" will orient our motives and drive our choices. We believe that we can partake in an action by choosing between alternatives and in doing so, will make ourselves better off. Because we are human, self-interest can lead to bad choices and actions, but it doesn't necessarily result in greed or coveting. Self-interest can and does involve sacrifice. It may be in one's interest to give up habits that are harmful, to work hard, and forgo leisure time, to sacrifice one's life for a family member. Greed never involves sacrifice. We need a society where greed is mitigated (not fueled by a system of incentives) and where self-interest encourages us to partake in profitmaking activities that also result in the service of others. Greed is unmitigated desire, a state of being in which one will steal, lie, cheat, and exploit 
to obtain any and possibly every whim or desire. Greed is thoughtless and harmful. It is important to remember that when ordering a society, we cannot solely concern ourselves with the incentives that ordinary people face, but the incentives that political leaders and those in power face. If we want political leaders, like those in North Korea, or China to change their behavior, we must focus on how to change the incentives they face. In the market, entrepreneurs who are both fallen and fallible are directed by the signals of profit and loss. These signals induce the entrepreneurs into activities that unleash their ideas in the service of other, ordinary people, whom they will never meet. Thus, markets do not require benevolent individuals with perfect foresight to plan economic activity but are rather guided by the interests of others in the pursuit of their own gain. These incentives guard against systemic failure because the losses, which are directed by consumers, are avoided. Prices provide these incentives and profit and loss direct behavior by serving as a feedback mechanism.

For all of this to work well, we need proper incentives. For the believer, these incentives are pleasing God. When we seek to please God in all that we do, when we ask him to be present with us in every choice, we can better steward our scarce resources for his glory, and he blesses our efforts. When we act out against God's will and his good design for us, we face frustration; we are pursuing a way the world was not meant to be. Receiving the richness of God's pleasure and blessing based on our obedient stewardship is the ultimate incentive, born out of our response to God's love and grace. Humans will not act without a motive; they must be propelled by their purposes to act. Then, when presented with choices we can reason through our alternatives and their consequences, although this process remains difficult. As the parable of the talents demonstrates, the pleasure of the master is the ultimate incentive.

The last economic and human reality we must assess is our interdependence. We are made in the image of God but are limited and finite in ways that he is not. We cannot do most things that we need to survive, and this was God's intention. God designed his people to be in community and to rely on each other's gifts and talents. Our limited nature and our diversity bring us together through trade, allowing us to thrive. I go to work and trade my time for income. I can use my income to purchase any variety of consumer goods relative to my budget. Human well-being and prosperity is advanced when I can get more for less: when housing, healthcare and food and shelter needs can all be met with better 
and better products. When those products are not solely available for consumption by the rich but across all income quintiles through the process of market competition-then we can realize a system where we can each go to work and use our gifts to serve (recall the use of the word abad in the Hebrew translation of Genesis 2:15) our fellow human beings. The extended order of the market economy also ensures that those benefits do not remain isolated or localized, but through global trade are carried across the globe. It is the extension of the market economy which is predicated on our need for trade and our desire to serve others that has lifted the masses out of poverty at exceedingly high rates. World poverty has been cut by $36 \%$ since 1990 and the world poverty rates continue to fall at rapid rates. Today for the first time in human history, the global abject poverty rate (those living under $\$ 1.90$ per day) is less than $10 \%$.

It is global trade and widening circles of exchange that has allowed this to happen. Trade includes those who have been excluded. It gives them access to goods and services that they formerly went without or obtained on their own. Trade fostered by market entrepreneurship is inclusive and extends its benefits in egalitarian ways, as evidenced by the rapid decline in poverty. This system of trade is essential for flourishing, and it is only made possible when we can depend on each other. Trading based upon on subjective value allows us to be free to do what God created us to do. We don't have to figure it all out because we were not made to do everything. Only God can do that.

Trade allows us to profit in our time while lowering all our costs. As we discussed, when we make a choice, we always bear a cost. The cost is the forgone opportunity at that moment in time, known as the opportunity cost. Trade brings strangers together to serve each other. For this to work well, we need a society that embraces the biblical principles of peaceful cooperation. Markets are an important aspect of that society buttressed by limited and peaceful government, extended cooperative international relationships, the rule of law and a robust civil society empowered by religious freedom, political freedom and economic freedom.

An extended cooperative and prosperous social order requires a market-based society predicated on property rights, profit and loss, prices, and the rule of law. Property rights are a necessary incentive for trade. Property rights also provide the basis for the emergence of prices. As prices fluctuate, they help us evaluate what we want based on our subjective values. Prices change based on changing scarcity levels and when they do, we reevaluate each choice, all in the pursuit of profit. Property 
rights give us boundaries, establish and protect our ownership rights, and provide a basis for trade.

Prices also help us seek profit and avoid losses personally and in our business ventures. When someone brings a product to the market, they seek to make money and have residual resources left over. Profits and losses are levied by consumers. The products and services available to us are only available if they are profitable. They are only profitable if they serve the needs of the consumer in some way. Profitable products and services free consumers from figuring out how to do those things on their own. Prices then provide information that we could never acquire on our own. Where prices exist, we are already better off than we would be without them; we have a benchmark to evaluate trade-offs and economize on our time.

This complex system of trade requires the rule of law. The rule of law means that everyone is treated equally before the law, that the law is transparent, laid out in advance, and that the leaders must submit themselves to it. The rule of law prohibits arbitrary behavior on behalf of rulers and allows for predictable behavior on behalf of everyone.

F. A. Hayek, in his famous book The Road to Serfdom, warned that as the state plans more of people's lives, we begin to shred the rule of law. ${ }^{\text {ll }}$ As a state takes over more economic activity, society converts into a law of specific and exclusive rules rather than the rule of law. There is debate in the economic literature regarding how much government intervention in an economy leads to such disastrous results and certainly most of the world lives in what we would deem "mixed economies." For Hayek, and for our consideration, the relevant question is the role of government as it pertains to human flourishing. Beyond that role, the quintessential question of political economy is how to constrain the state from growing larger and dominating more of the private sector. Leaders will start to change the rules to suit their will rather than submit their arbitrary whims of power to a preexisting set of rules. This happens precisely because the state does not have any idea how to order economic affairs. They don't know what types of products various consumers want nor could they fully comprehend the production process and the relative trade-offs to understand how to bring goods to consumers. Nor do they have the incentives (profit and loss) to learn how to bring these items to the consumers that

${ }^{11}$ Hayek, Friedrich A. von and Bruce Caldwell. The Road to Serfdom: Text and Documents. Chicago: University of Chicago Press, 2007. 
need and want them at the lowest possible cost (the hallmark of prudence and stewardship).

Without the rule of law, we lose predictability of state behavior. One cannot have confidence that state agents will not break into their property and steal all of their possessions. The rule of law limits the state's ability to plunder and to infringe on our ability to choose as God directs us. When we live in a society with the rule of law, we can make plans, for living out God's desires in our life. If God is calling you to open a business or a church, property rights and rule of law will make that much easier. You can raise money for investments in buildings and businesses. The rule of law is essential for well-protected, well-defined, and transferable property rights. In early Christianity the rule of law was not broadly operationalized in society so not everyone benefitted from the benefits of well-protected property that applied equally to all in society. Society loses when property rights and protections are not established with generality and accessibility to all citizens.

When we have property rights and the rule of law combined with political, religious, and economic freedom, ${ }^{12}$ we can pursue God's purposes as they pertain to our unique lives. When any of these three freedoms are limited, we are less free to be wholehearted stewards.

\section{CONCLUSION}

We must understand God's purposes for life as he wishes and be the best stewards we can with what he has given us both individually and collectively. We are designed to live among each other and serve each other. We never were designed for atomistic individualism. When we can order society in a way that allows us to rely on each other, to embrace our interdependence, then we have the best chance, through our work to serve one another and make lasting contributions to human flourishing and in doing so help each other and glorify God.

We require an[d] extended social, economic, and political order that allows each person, created with dignity, to unleash their human creativity as God leads them. This necessitates a market economy where dispersed individuals can discover, learn, and through the system of profits and losses can find ways to serve one another. When society is predicated

${ }^{12}$ Gwartney, James, Robert Lawson, and Joshua Hall. Economic Freedom Dataset. Report. Frasier Institute, 2015. http://www.freethe-world.com/datasets_efw.html. 
on these realities of human nature and scarcity of resources it is best positioned to make kingdom-building advances to human flourishing. All of this suggests that there is a path to prosperity and a path that pushes societies away from prosperity. When societies are ordered in ways that ignore human nature and try to order economies from the top-down, immiseration follows as is evidenced by the devastation of centrally planned economies in the twentieth century including but not limited to: Mao's China, Stalin and Lenin's Soviet Union, the Khmer Rouge in Cambodia, and Tito's Yugoslavia. ${ }^{13}$ This phenomenon is not a historical artifact or dated history that somehow, we have overcome. Today's Venezuela ${ }^{14}$ and North Korea provide extreme examples of twenty-first-century experiments with top-down planning-they lead to human misery and diminish the capacity for ordinary people to provide for their families and communities-people are forced inward to merely focus on survival and many do not.

But what about modern-day China? China in just 40 years with limited economic reforms has lifted almost 800 million of its citizens out of abject poverty. ${ }^{15}$ China has gained economic freedom since the late 1970s and now is a place where global corporations flock to open manufacturing plants which provide jobs and opportunities for those who very recently were destined to subsistence farming. The extension of global markets to China is allowing the Chinese to experience their own Industrial Revolution in a much shorter time that the West first experienced it. These are good things and they include in global markets people who were forever excluded. But can China maintain a mixed economic and political strategy of limited market economies and authoritarian political control? It remains to be seen what the future will be for China. Now it is characterized by the World Bank as an upper-middle-income country that is transitioning to a market economy. ${ }^{16}$ This is the greatest hope China

${ }^{13}$ Rummel, R. J. Death by Government: Genocide and Mass Murder Since 1900. Routledge, 5th Printing Edition, 1997.

${ }^{14}$ Today, Venezuela ranks last in the world in Economic Freedom and is expected to experience an inflation rate of one million percent. Mass emigration, rioting and empty shelves are the norm. The government continues to vie for control and pacify the population, it's latest attempt with yet another minimum wage hike. None of this has helped the economy or it's people.

15 The World Bank in China. http://www.worldbank.org/en/country/china/overview. ${ }^{16}$ Ibid. 
has ever had for sustainable human flourishing characterized by personal liberty, but China isn't there yet. It is quite possible that advances in economic freedom that have already been obtained will pave the way for more economic freedom and political freedom, but there is no guarantee. Milton Friedman and F. A. Hayek hypothesized, which is supported empirically, that economic freedom is a necessary but not sufficient condition for political freedom. ${ }^{17}$ Meaning a free market economy is a necessary but not sufficient condition for a country to transition to one of liberal democracy and limited government.

China could easily lapse back into a fully planned economy and with it will lose the precious gains its citizens have obtained. When political leaders attempt to "design" society in a way that they think will benefit them the most, economic failure most often results. There is a path to prosperity and it requires a market economy which best, although not perfectly, allows for maximizing biblical human flourishing. The ethos of freedom, human agency, property rights, service, and the common good must be at the core of any economic order and then the incentives must follow. This is the path for stewardship.

\section{BIBLIOGRAPHY}

Grudem, Wayne A. Systematic Theology: An Introduction to Biblical Doctrine. Grand Rapids: Zondervan, 1994.

Gwartney, James, Robert Lawson, and Joshua Hall. Economic Freedom Dataset. Report. Frasier Institute, 2015. http://www.freethe-world.com/datasets_efw. html.

Hayek, Friedrich A. von, and Bruce Caldwell. The Road to Serfdom: Text and Documents. Chicago: University of Chicago Press, 2007.

Keller, Timothy. Generous Justice: How God's Grace Makes Us Just. New York, NY: Dutton, Penguin Group, 2010.

Lawson, Robert A., and Jeff Clark. "Examining the Hayek-Friedman Hypothesis on Economic and Political Freedom." Journal on Economic Behavior and Organization, 74, no. 3 (2010): 230-239.

Mises, Ludwig von. Human Action: A Treatise on Economics. Auburn, AL: Ludwig von Mises Institute, 2008.

${ }^{17}$ Lawson, Robert A. and Jeff Clark. "Examining the Hayek-Friedman Hypothesis on Economic and Political Freedom." Journal on Economic Behavior and Organization, Vol. 74, Issue 3, 2010, pp. 230-239. 
Pennington, Jonathan. "A Biblical Theology of Human Flourishing." The Institute for Faith, Work \& Economics, 2015. http://tifwe.org/resources/abiblical-theology-of-human-flourishing- $2 /$.

Plantinga, Cornelius. Not the Way It's Supposed to Be: A Breviary of Sin. Grand Rapids, MI: Eerdmans Publishing, 1995.

Redd, Scott. Wholehearted: A Biblical Look at the Greatest Commandment and Personal Wealth. McLean: The Institute for Faith, Work \& Economics, 2016.

Rummel, R. J. Death by Government: Genocide and Mass Murder Since 1900. London: Routledge, 5th Printing Edition, 1997.

Staub, Dick. "What Made in the Image of God Really Means." Relevant, March 4, 2013. http://www.relevantmagazine.com/god/deeper-walk/ features/23549-qmade-in-the-image-of-godq.

Whelchel, Hugh. How Then Should We Work? Rediscovering the Biblical Doctrine of Work. Bloomington, IN: WestBow Press, 2012.

Open Access This chapter is licensed under the terms of the Creative Commons Attribution 4.0 International License (http://creativecommons.org/licenses/ by $/ 4.0 /)$, which permits use, sharing, adaptation, distribution and reproduction in any medium or format, as long as you give appropriate credit to the original author(s) and the source, provide a link to the Creative Commons license and indicate if changes were made.

The images or other third party material in this chapter are included in the chapter's Creative Commons license, unless indicated otherwise in a credit line to the material. If material is not included in the chapter's Creative Commons license and your intended use is not permitted by statutory regulation or exceeds the permitted use, you will need to obtain permission directly from the copyright holder.

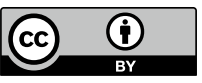




\title{
Rationality and Alienation: Themes from Gandhi
}

\author{
Akeel Bilgrami
}

\section{INTRODUCTION}

This is not intended as a scholarly paper on Gandhi's philosophical ideas on rationality and alienation. What I will seek to do instead is to construct an argument from a range of philosophical claims that Gandhi made and through that argument, I will explore conclusions that entirely square with Gandhi's thinking on ethics, politics, and political economy.

I'll begin simply by briefly listing in no particular order four of these philosophical claims in his writing and then proceed in the rest of the paper with the construction of the argument, invoking these claims as and when the stages of the constructed argument require them.

First, Gandhi took ethics to be a primarily perceptual discipline. In his view, the world, the perceptible world we inhabit over and above containing the properties that the natural sciences study, contains properties of value and meaning that make normative demands on us to which our practical agency responds. Such a view has recently been attributed to Aristotle by the contemporary philosopher John McDowell, contesting

\footnotetext{
A. Bilgrami $(\bowtie)$

Columbia University, New York, NY, USA

e-mail: ab41@columbia.edu

(C) The Author(s) 2020

T. Akram and S. Rashid (eds.), Faith, Finance, and Economy, https://doi.org/10.1007/978-3-030-38784-6_4
} 
the view of Hume and Adam Smith ${ }^{1}$ that values derive entirely from our states of mind (our desires and moral sentiments); rather such states of mind are instead merely our affective responses to the perceived value properties in the world around us. Aristotle is certainly not the source of Gandhi's perceptualist meta-ethics. His sources are the Vaishnavite traditions that he grew up in as well as the Bhakti and Sufi influences on his thinking which took the world (including nature) to be sacralized and thus suffused with value, as did a centuries long tradition of popular (if not always high) Christianity. ${ }^{2}$ On this view, values are not all made up by us and our states of mind such as our desires and moral sentiments as they were for Hume and Adam Smith. Instead, our states of mind are responses to a world around us that contains values. Thus, for instance, desires themselves are responses to desirabilities (or values) in the world that we perceive around us. In other words, the world consists not just of the properties that natural science studies but also normatively described properties, desirabilities and undesirabilities such as, for instance, kindness and cruelty, well-being or poverty, and our states of mind, our desires and moral sentiments, are not the source of value but are merely responses to these values that we perceive in the world.

\footnotetext{
${ }^{1}$ For Hume, see Enquiry Concerning the Principles of Morals, 1751. Online version may be found at https://www.gutenberg.org/files/4320/4320-h/4320-h.htm. For Smith, see The Theory of Moral Sentiments, 1759. Online version may be found at https://www. earlymoderntexts.com/assets/pdfs/smith1759.pdf.

${ }^{2}$ References to this sort of understanding of value as having its source in a sacralized conception of the world are peppered all over a very vast corpus of Gandhi's writings in letters, speeches, and dispatches to magazines such as Harijan and Young India. He refuses to distinguish between animist traditions (or for that matter mystical Bhakti and Sufi traditions) and Hinduism, and he dismissed such classificatory distinctions as a late British taxonomizing that simply did not apply to India's religious life. In response to a question by a Dr. Chesterman, the medical secretary of the English Baptist mission, he says, "...in spite of being described as animists these tribes have from time immemorial been absorbed in Hinduism. They are, like the indigenous medicine, of the soil, and their roots lie deep there" (Harijan, February 25, 1939). This sort of thing is equally true of popular Christianity. It is frequently continuous with a variety of mystical, Gnostic, and Neo-Platonist elements filled with references to a sacralized nature shot through with value properties, and it is only a high Christianity of the seventeenth century that very deliberately dismissed these popular Christian ideas as 'dangerous enthusiasm'. For a good discussion of this, see J.R. Jacob's Robert Boyle and the English Revolution (Burt Franklin and Company, 1977) and Simon Schaffer's essay, "The Earth's Fertility as a Social Fact in Early Modern England," in Mikulas Teich, Roy Porter and Bo Gustafsson (eds.), Nature and Society in Historical Context (Princeton University Press, 1997).
} 
It is not as if Gandhi, in claiming this primacy of perception, denied that there is ethical deliberation. Rather he thought that deliberation is a secondary sophistication, it occurs either when we have conflicting perceptions of what the value-laden layout of the world demands of our practical agency (or when we find that our initial or instinctive agentive responses to those perceived normative demands are not adequate). It is only then that the usual deliberative cogitations of ranking and weighing (or selfcritical reflection) are made necessary.

A second philosophical claim needs to be negatively formulated, a point really about what is conspicuously missing in Gandhi's philosophical outlook. It is remarkable that though he thought long and hard about the nature of politics, he never took the ideals of liberty and equality, as they were theoretically developed in the political Enlightenment, to be very central in his understanding of the polity. And in this, though he never deployed the analytical category 'bourgeois' in his writings, he shared an attitude of indifference towards these concepts with Marx who, as we know, dismissed them both as bourgeois ideals. ${ }^{3}$

And so-this is the third philosophical claim-to the extent that he wrote about liberty at all, his conception of individual liberty was that it was a form of self-governance. Individual liberty, for him, lay in each one of us making decisions that shape our material and spiritual lives and democracies are substantially (as opposed to merely formally) in place only when individual liberty, so understood as self-governance, does in fact translate into our shaping the world to be in accord with these decisions.

Finally, a fourth and large philosophical claim that was close to his heart was to make the chief goal of politics and social life, the overcoming of an increasing alienation that he thought was pervasively present in modern societies, an alienation that owed chiefly, in his view, to an increasing attitude of detachment in our relations and our perspectives on each other and the world-where the opposite of detachment is not attachment so much as engagement. He often expressed what he had in mind by such detachment by asking the question: How is it that we have transformed the idea of the world as not merely a place to live in but a place to master and control? Realizing that this was too general and omnibus a way of expressing the notion of alienation, he broke down that question into more tractable questions, such as the following in particular: How is it

\footnotetext{
${ }^{3}$ See Karl Marx, On the Jewish Question, in Robert Tucker (ed.), The Marx-Engels Reader (Norton, 1978).
} 
that we have transformed the concept of nature into the concept of natural resources? How is it that we have transformed the concept of people into the concept of populations? How is it that we have transformed the concept of knowledges to live by into the concept of expertise to rule by? And even, and this is startling for us who have been brought up on liberal doctrine: How is it that we have transformed the concept of human beings into the concept of citizens. Gandhi tries to dig deep here to show that all these transformations are really, at bottom, the same transformation, in that they all reflect an increasing alienation and disengagement in our outlook on the world-in our understanding of nature, human subjects, and human knowledge. Though he was not a socialist, like Marx he thought much of this disengagement of modernity owed to capitalist economic formations and he thought at the time of his writing that India was at the crossroads that Europe was in during the Early Modern period and he was anxious that India not go down what he thought was a lamentable path that Europe had from Early to Late modernity. It is striking, then, that for all their large and well-known differences, in stressing alienation and not stressing liberty and equality, he was Marx's intellectual partner.

With these four claims in place, I'll proceed now to the main body of the paper and the construction of the promised philosophical argument which will eventually integrate these seemingly miscellaneous Gandhian claims.

\section{A Counterargument Against THE LOCKEAN CONTRACT}

In India recently there was widespread protest against the government's promotion of corporate projects via an 'eminent domain' form of dispossession both of the poor peasantry in various parts of the countryside as well as of the foresters from the extensive commons which they inhabited and which was their only source of sustenance. Against this protest, even so humane an economist as Amartya Sen declared that 'England went through its pain to create its Londons and Manchesters, India will have to do so too'. Sen's remark, which appeals to history, surprisingly fails to notice how historically imperfect his analogy is. When vast numbers of

\footnotetext{
${ }^{4}$ Amartya Sen, "Prohibiting the Use of Agricultural Land for Industry Is Ultimately Self-Defeating." The Telegraph (Kolkata), 23 July 2010.
} 
people who eked out an agrarian life were displaced in England in order to create its Londons and Manchesters, they moved in hardly less vast numbers to other temperate regions of the world, mostly in fact to North America, and set up life there as settler colonists. There is nowhere for the poor of rural Bengal and other parts of India to go, except to its already glutted metropoles where they have no future but to squat illegally in vast unlivable slums ridden with poverty and disease, their drinking water polluted, their children prey to mafia gangster recruitment, and where most will be unemployed while some, if they are lucky, will get casual, part time, and chronically impermanent employment. History apart, Sen's analogy may have had a point today, if the mobility of labour had some parity with the mobility of capital. But in a time (ever since the dismantling or remantling of the Bretton Woods institutions), when capital can fly out of a nation at the press of a button while national immigration laws severely restrict the mobility of labour, Sen's analogy comes off as callously off beam.

But it is not this failed analogy that I want to pursue so much as the assumption that underlies his remark. In making that remark, Sen was not just expressing a considered view that is widely held among economists and social scientists, he was also revealing an instinct and assumption widely taken for granted among the lay intelligentsia. What underlies this assumption?

It may seem, at first sight, that what underlies it is a commitment to some sort of 'iron laws' of history and political economy, whereby what happened in Europe in the Early Modern period will happen everywhere else, including Europe's erstwhile colonies. It is sometimes said that a certain rigid stagial reading of Marx had proposed something like these laws. That is a vexed interpretative issue in the study of Marx. But in liberal political doctrine, which is much more the framework within which Sen writes, it is not any such determinism that motivates the assumption. Rather, liberalism with its normative claims about rationality, presents the underlying thought as not (or not merely) descriptive, but prescriptive: 'What happened in Europe in the Early Modern Period must happen elsewhere because what happened in Europe was rational.'

Let us explore this claim to rationality.

What social theory can be said to have established that it was rational for Europe?

In the Early Modern period, one particular social theory argued with clarity and with the force of the great intellect of its propounder for the 
political rationality and therefore the historically progressive necessity of the very incipient forms of capitalism that can be located in the privatization of land out of the commons. This theory was contractualist in conception, in particular the contractualist strand that owes to John Locke. ${ }^{5}$

The point of all social contract theory, whether Lockean or any other, is to establish that in an originary scenario described as a 'state of nature' (or an 'original position') which is a pre-political condition, freely chosen consent by a people to certain principles or arrangements to live by immediately transforms those people into citizens, and the state of nature into a polity-but it only does so, if the consent to those principles and arrangements is demonstrated to be rational in a very specific way: the principles and arrangements must first be freely consented to and second they must make these people better off as citizens than they hitherto were as mere people, prior to polities, in a state of nature.

In the contractualist strand I am concerned with the canonical scenario has it that were someone in a state of nature to come upon a stretch of land in the common and fence it and register it at an elementary form of bureau that they set up for this kind of registry, then the land becomes his. Suppose then that this is done by some of the people and they each keep faith with the general requirement I mentioned above that this can only be done if no one is made worse off and at least some are made better off than they were in the state of nature, a requirement which they then elaborate further by adding the following crucial clause: if those who had done this were then to hire others at wages which enable them to live better, then this too would be an arrangement that is rationally justified since they too were in fact better off than they were in the state of nature.

Such was the explicit claim of the Lockean ideal of the social contract (roughly an argument from Pareto-improvement) which went on to became the cornerstone for certain political principles and arrangements that came to be called liberalism in which among other things such as free speech (except for atheists, heretics, and Catholics,...), private property and wage labour were seen as progressive advances justified by the mutual advantage or amelioration of all concerned (or in the limiting case, amelioration for some and no resulting disadvantaging of anyone else).

${ }^{5}$ John Locke, The chapter on property in the Second Treatise on Government (Mass Market Paperback Publishing, 2008) is the locus classicus. 
When one asks the question, what in the historical context was motivating the articulation of such a contractualist theory, the answer is that the theory philosophically consolidated the system of enclosures which had been practised by brute force for many decades earlier, and in doing so it prepared the ground for it to become a form of right with law and governance to back it up. The point was to present the political principles and arrangements which justified the system of enclosures as a moral and political achievement since it was implicitly based on a form of rational and freely chosen consent.

Marx's 27th chapter of Capital, which presented in detail the predatory nature of such primitive accumulation in general, but also of the enclosures in England in particular, had its premonitional anticipation in the widespread protest against the enclosures among some of the radical groups during the English revolution who pre-dated Locke but whose protest on behalf of a quite different ideal of the collective cultivation of the existing commons could be seen as seeking to preempt the claim to rationality in Locke of such an implicit consent that he had attributed to all in the originary scenario of a state of nature. Let me, then, construct a specific counterargument against the Lockean contract and attribute it implicitly (and, of course, anachronistically) to these dissenters as the theoretical source of their protest and as proposing instead an alternative notion of consent. Thus someone like Winstanley could have been heard as anachronistically saying to Locke: 'The entire contractualist scenario as you have presented it generates an opportunity cost. An opportunity cost is the cost of an avoided benefit paid for making a certain choice. That avoided benefit is the collective cultivation of the commons that is prevented by the choice to privatize the land in your initial step in the scenario. Once the step is taken, it is true what you say that those who were hired for wages are better off than they were in the state of nature but they are not better off than they would have been if the land had not been privatized in the first place and if there was a collective cultivation of the commons instead'.

The criticism is based on a relatively simple counterfactual. But despite its simplicity, its theoretical effect is more complex and interesting because, as I said, it proposes a quite different notion of consent than the one that Locke assumes. Consent must now be viewed as a more complicated act than Locke understands, it should be viewed as follows: Whether someone can be said to have consented is not necessarily to be viewed as this tradition proposes but rather viewed as what he or she 
would choose in antecedently specified sorts of conditions that did not obtain - in which case the entire Lockean tradition of thought may be assuming that we have implicitly rationally consented to something which we in fact have not.

If, in this way, we shift the focus of this imagined dispute between the preemptive Winstanley and Locke to which notion of implicit consent is at stake in the social contract, a further issue opens up about the nature of freedom and coercion of the consent. Suppose that Locke were to respond by saying: 'I have offered a perfectly good notion of implicit consent and I see no reason to accept yours'. Winstanley's response would then presumably have to be: 'If you ignore my counterfactual and insist that the sense of consent you have on offer suffices in the contractarian scenario and that everyone has indeed implicitly consented in that sense, then I will have to point out that the implicit consent you have attributed in particular to those who are hired to work for wages, was coerced by a condition that they could not avoid: their non-possession of the land in the face of others' possession of it. $M y$ alternative notion of consent was articulated with the view to establishing that that condition of non-possession in the midst of possession by others, should be seen as avoidable. So, your insistence on your notion of consent, even despite the assertion of my counterfactual, brings out in the open that possession of the land by some and not others is a coercive condition in which the latter has to "consent" in your sense of the term. And so the contractualist tradition presents a coerced implicit consent fraudulently as a freely chosen implicit consent'.

I had said earlier that a great deal of social theory presented the developments in political economy in the Early Modern period as advances in political rationality; and it is their rationality which was invoked as the basis for later claims that the rest of the world, including Europe's erstwhile colonized lands, would have to inevitably adopt these rational political and economic arrangements as a historically progressive and therefore necessary form of development. But, if I am right, the entire claim to the premise of the argument, i.e., to the rationality of the contractual ideal that philosophically rationalizes historical developments in England, depends on two things: (a) on what is consented to making one better off and (b) the consent being freely made. However if the criticism attributed as implicit in Winstanley's dissenting stances is correct, these two conditions cannot be satisfied jointly. The counterfactual notion of consent offered by Winstanley's implicit criticism makes clear that the first requirement has 
not been met, and if you simply deny the counterfactual notion of consent, the other notion of consent fails to meet the second requirement that the consent be freely chosen.

That, therefore, leaves these social theorists without their premise, to say nothing of their conclusion.

But it would be too quick and premature to rest the counterargument here. Why? Because Locke in the Early Modern period only began an argument that I have been countering on behalf of the radical dissenters. His argument, it might rightly be said by way of reply to my counterargument, has been updated and fortified by more recent theoretical developments within the framework of liberal political thought that he initially generated. Any counterargument against Locke would have to address this subsequent fortification as well. What are these theoretical developments that provide the fortification of Locke?

The riposte to Locke that I put in the mouth of the preemptive dissenting voices in Early Modern England made counterfactual use of the ideal of a collective cultivation of the commons. But liberal theory more recently has deployed further conceptual resources to try and undermine this ideal. So, let me now very briefly address one central strand of such resources, which will allow me also to come to my Gandhian themes of alienation and human subjectivity.

\section{The Tragedy of the Commons}

Perhaps the most standard resource that liberal theory relies on is the idea and argument behind what has come to be called the "tragedy of the commons'. Following Garret Hardin, ${ }^{6}$ who wrote the seminal paper making this argument (summarizing a long tradition of economic thinking), the idea, roughly, is to raise as an intractable problem for any ideal of cooperative life, such as collective cultivation of the commons. The intractable problem that is supposed to arise is that individual human psychology at its most rational is required to behave in ways that undermine the collective by failing of the cooperation needed to keep it going. This is because the collective ideal asks the individual to contribute resources (sometimes restraint may be a negative form of contribution of resources, when the goal is, say, to prevent overuse or over-cultivation of the common) that

${ }^{6}$ Garret Hardin, “The Tragedy of the Commons.” Science, 13 December 1968. 
produce a benefit that is shared by and therefore divided over the whole collective over the long run while the cost is borne immediately by each commoner. If everybody does what is required of him or her, of course everyone gains. But since one is in the [epistemic] dark about whether others are contributing their bit of the resources demanded of them, one is constantly stricken with the qualm that one's contribution would be wasted if others don't do their bit. In such an understanding of the collective ideal-which is extensively present in many liberal frameworks of social thought-some individual commoner who decides not to cooperate therefore is always at an advantage since the gains of non-cooperation will be immediate and all for oneself and completely assured whereas the gains from cooperating are long-term, dispersed over the whole group and, above all as just said, always uncertain. Non-cooperation for him, as an individual, would thus be rational. But the commons cannot survive if each individual does this individually rational thing. It is doomed. Thus the tragedy. So privatization is a better bet.

It is often said in critical response to this liberal argument that the tragedy of the commons idea can be developed not in the direction of providing a rational basis for privatization but rather to argue for the regulation of the commons and its collective use by detection and policing and punishment of non-cooperation. In fact, Elinor Ostrom's fine analytical and extensive empirical study presents the principles for such regulation after a scrutiny of various commons and their governance in four continents. Now, who can be opposed to such regulation? It is obviously a good thing. There is no gainsaying that. But given the kind of thinking that frameworks the liberal argument of the tragedy of the commons, this criticism and reinterpretation of it is not getting at what is fundamental in it because the idea of policing and regulation is susceptible to the same considerations of the tragedy of the commons, one step up. Even if we ignore the well-known difficulties of detecting many non-obvious forms of non-cooperation, the fact is that mechanisms of policing and punishment to prevent non-cooperation are also susceptible to the argument that underlies the tragedy since the same dilemma can be raised for why anyone should cooperate with policing and detection and punishment if he can get away with not cooperating-by offering bribes, for instance, or making mafia style threats against those who detect and police or those

${ }^{7}$ Elinor Ostrom, Governing the Commons (Cambridge University Press, 2015). 
who cooperate with the policing and detecting (such as witnesses), or by [loopholing] the laws to make non-cooperation legal after all...all familiar and pervasive phenomena in a wide range of societies, with the last of these strategies most operative in societies that congratulate themselves on have transcended political corruption exemplified by the other more blatant strategies of bribes and threats. As a result, though we must obviously accept the idea of regulation as something we should certainly strive to put in place, it may be worth probing whether the problem does not lie much more fundamentally in its basic way of thinking and that can't be rectified by solutions like 'regulation' and policing, solutions which, as I said, are in any case vulnerable to this thinking and therefore vulnerable to the same strategy of argument that generated the 'tragedy of the commons'.

Short of a more fundamental critique, it may rightly be said that Locke, anticipating these later arguments in favour of privatization, was correct to see his version of the implicit consent of all contractors (possessors and non-possessors of land) as rational, indeed even freely chosen if the contractors had an implicit or tacit understanding of the looming threat of the 'tragedy of the commons'. The counterfactual-based notion of implicit consent presupposed by the dissenters, by contrast, is precisely doomed to such a 'tragedy', unless a more fundamental critique is provided of the thinking involved in the very statement of the argument that there is a tragedy that looms. Actually, I don't even have to take a stand on whether or not there are constraints internal to this way of thinking that will ensure the rationality of cooperation. What I do want to do, however, is to step back and present, from a more external perspective-and this is really Gandhi's perspective-what I think is revealingly wrong about the whole way of thinking that underlies the argument of the tragedy of the commons and thereby hint at an alternative outlook on the possibilities for our political ideals. To provide this more fundamental scrutiny of this line of defence of the Lockean social contract, I will have to, as I said, step back first and setup a dialectic that looks to another very central line of development in liberal political philosophy.

\section{LIBERTY AND EQUALITY}

It is a large and familiar curiosity that liberal doctrine, as soon as it articulated its two great ideals of liberty and equality, went on over the next two centuries to theoretically develop them in a way that put them in 
indissoluble tension with one another. The cold war rhetoric with one side claiming to pursue liberty but damned by the other as pursuing it at the cost of equality and vice versa by the other side, is only the crudest and most publicly familiar symptom of this perverse development. The tension was charted in far more sophisticated theoretical work for well over a century before the cold war.

What generated the tension? The fault line lay in certain familiar features of liberty that generated inequalities. There are a number of such features but I just mention two. The most well-known and well-studied feature is that the possession of property bestows a particular form of liberty on its possessors (something justified by arguments such as the one I just presented above from the social contract and fortified by tragedy of the commons arguments) putting it structurally at odds with equality in ways that are so widely studied that I need not say anything more about it just here. Marx was only its most well-known critic but a wide range of other political traditions have linked the unconstrained right to the accumulation and possession of property and wealth with the chronic inequalities in our societies. ${ }^{8}$ Another less studied and more interesting and perhaps even (psychologically) deeper feature is what I will call 'the incentivization of talent', also pervasive in liberal ways of thought and taken for granted by virtually everyone within its orbit, and not necessarily only theorists and intellectuals. Talent, in liberal theory, was initially distinguished from the capacity for labour, which it claimed was evenly distributed among people while talent was not. But with notions of liberty as individual self-governance emerging in liberal thought, it was said to be wrong to exclude talent as a source of individual liberty. Notions of dessert, the right to reap the praise and reward for the productions of one's talent, became central to one's exercise of self-governance. If one did not allow praise and reward to the talent responsible for these productions, it would mean that one instead praised the zeitgeist for the productions, and that would be to deny the very place of individuals, seeing them as mere symptoms of the zeitgeist in embodied human form, a deprivation of the liberty and rights of individuals. Moreover, this liberty and right via notions of dessert also generated the liberty and right of all others to enjoy the productions of given individuals' talents, productions which were incentivized by the liberty attaching to their individual talent, to be

\footnotetext{
${ }^{8}$ For non-Marxist traditions, to name just three, see the anarchism of Proudhon, the work of John Ruskin or of William Morris.
} 
as excellent as they could be. And all this generated inequalities in ways that are too obvious to elaborate-since talent is not equally distributed, making the reward of talent a right of individuals would inevitably lead to inequalities.

Since these features and their effects on the two chief ideals of liberal doctrine are so entrenched in defining what those ideals are, there is no way to make the two ideals compatible without substantially revising the meanings of the terms 'liberty' and 'equality' as they have come to be theoretically elaborated in liberal theory. I am assuming here an inseparability of theory and meaning of the sort plausibly argued by Thomas Kuhn. ${ }^{9}$ So, except as is sometimes done in shallow taxonomical exercises, meanings in general cannot just be changed stipulatively and by fiat. The terms or concepts to be transformed need to be embedded in doctrinal or theoretical reformulations first (shifts of paradigm, as Kuhn called them) before the revisions to meaning are plausibly made and if the new meanings are to be non-arbitrary. How might this be done? It is here that some of Gandhi's ideas that I listed at the outset suggest one path on which one might proceed.

So, here is how I've allowed myself to think of it.

A natural way of reading Gandhi is this: Because of the irresoluble tension between them in our inherited understanding of them, let's remove the ideals of liberty and equality from centre stage, where liberalism had placed them, and put on centre stage instead an even more basic ideal, never very central to liberal thought, and then, usher liberty and equality back in later (from the backdoor, as it were), but now not as centralrather merely as necessary conditions for this other more primitive idea that is on centre stage. So understood, liberty may have some serious chance of no longer being understood in the previous terms that put it in tension with equality. And, looking to traditions outside of the mainstream of liberalism, whether it be Marx or Gandhi, an ideal that might be on offer to take centre stage as being even more fundamental than liberty and equality, is the ideal of an unalienated life.

What is this ideal of an unalienated life? Let me now try and spell that out along lines that Gandhi instinctively formulated-keeping in mind the eventual task I have set myself: that of defending the counterfactual-based notion of consent of the dissenters against the particular way of thinking

\footnotetext{
${ }^{9}$ Thomas Kuhn, The Structure of Scientific Revolutions (University of Chicago Press, 2012).
} 
that generates the tragedy of the commons that would sustain and fortify Locke's idea of a consent to a privatized economy.

\section{An UnAlienated Life}

The first thing to note is that the term 'an unalienated life' is ambiguous. One sense of it is the unalienatedness that came with the sense of belonging that was made possible by the social frameworks of a period prior to modernity. All political and social theorists-Marx and Rousseau are only the most prominent-have tended to agree that whatever the defects of societies prior to modernity were, alienation was not among the defects. It is a malaise of modernity in particular. But the point remains that, as is well known and widely acknowledged by the very same theorists, the unalienated life of those earlier times was indeed marred by the oppressive defects in those societies frameworks. (To say 'feudal' to describe that oppression would be merely to use a vastly summarizing and somewhat misleading category that we have all been brought up on.) It is precisely those defects that the sloganized ideals of liberalism, Liberty and Equality, were intended as directly addressing. And I have argued that since the methodological and theoretical framework within which those two concepts were then developed made it impossible to so much as conceive how they could be jointly implemented, we should no longer see them as something to be directly deployed but rather as indirectly deployedmerely as necessary conditions for the achievement of a quite different (directly deployed) ideal-thereby transforming the concepts of liberty and equality. Now, if the achievement of an ideal of an unalienated life were to bring, in its wake-indirectly - conditions of liberty and equality (however transformed), it is bound to be very different from the unalienated life which is acknowledged to have existed in times prior to modernity because the conditions in which it existed then were also acknowledged to be acutely lacking in, precisely, liberty and equality. Thus, given this rudimentary conceptual dialectic, what we need to show is how a new framework that breaks out of the dialectic would solve [for] three things at once - a transformed notion of liberty and equality, as I have said from the outset, but also it would now seem a transformed notion of the unalienated life. So, this is to be conceived as a holistically triangular transformation-we overcome a certain conceptual-historical dialectic and in doing so together and at once transform all three concepts that feature in the dialectic. 
If this triangulated bootstrapping transformation of the notions of liberty and equality and the ideal of an unalienated life in concert, all at once, is the ambitious challenge to be addressed, a very general further question is suggested. We have to ask, first, what can be retained of the general idea of social 'belonging' of an earlier time in any revision of the idea of an unalienated life for our own time? We know from the other elements of the dialectic that the social belonging of an earlier time was marred by the defects of a lack of liberty and equality, but we also know from what I have said that the attempts to directly overcome those defects were, in turn, marred by the fact that liberty and equality flowered in conception within a social framework in which a highly individualized notion of individual liberty that attached to talent and property made for liberty's conceptual incoherence with equality. That was the fundamental source of the shortcoming of the liberalism that emerged out of the standard political Enlightenment. So it would seem to follow, then, given this entire dialectic, to conclude that a concerted and triangulated transformation of all three notions would have to find its first hook, find its initial root, in individual liberty being conceived of in non-individualistic terms. It is really its failure to be so conceived that led Gandhi to ignore it in his understanding of politics, but if we were to find a way of thinking of it in non-individualistic terms it would be quite of a piece with the ideal of an unalienated life that Gandhi thought central to politics.

Liberty for Gandhi, I have said, is the idea of self-governance, the power to make the decisions that shape the material and spiritual aspects of our lives. If so, it would seem then that to transform the notion of liberty in the way that we have just seen as being required, we would have to envisage each individual as approaching these decisions not primarily with her own interests in mind but the interests of others as well. Now, the last few words of that last sentence express something utterly familiar, a cliché, a piety. The critique of self-interest has long been with us. Moreover, since my goal is to show the shortcomings of the argument from the tragedy of the commons which is manifestly based on individual rationality as conceived in terms of individual self-interest, it is not all that interesting to just say that one is opposed to self-interest. But Gandhi was not merely saying that one should be opposed to self-interest. $\mathrm{He}$ was saying something more interesting for two reasons. First, he is saying something that has not, so far as I know, been said very much at all and certainly not been theorized very much. He is saying that what any such 
critique of self-interest amounts to is the construction of a notion of liberty. And second, he is saying, as I will very briefly expound below, that the transcending of self-interest is not just a matter of putting aside one's interests, but of seeing the world right because for Gandhi ethics (and our relation to values) is essentially a perceptual discipline. The point for him was not really ethical, then, so much as cognitive, though unlike us in our time, he did not see these as separate subjects.

Why is the first of these points so little known and developed? I repeat: Because individual self-governance (i.e., liberty) has for so long been viewed in individualistic terms. But what is it to have a non-individualistic conception of individual self-governance? It is not group or collective self-governance, which is a different notion (interesting in a different way) but not relevant to liberty which is felt and exercised by individuals (and indeed so is alienation undergone and felt by individuals). Rather, putting together two of the philosophical claims in Gandhi that I began with, it is something like this.

When we exercise our individual liberty in this new sense that is being proposed, when we make the relevant decisions that amount to such selfgovernance, we respond to the perceptually given normative demands that the world (both the natural and the social world) around us presents us with and to which our agency must respond. If this is right, then when we make the decisions that contribute to our self-governance, we have to see the world right, to see correctly what its normative demands are and respond to those demands. So the point is in a sense quite literally phenomenological. And now. if we add to this the demand that these perceptions and responses to perceptions must be of a piece with the ideal of an unalienated life, a further crucial insight is allowed-that to see these demands of the world for what they are in an unalienated social life, each one of our individual orientations on the world in perceiving the normative demands of its value-laden layout, has to be to something that goes beyond the orientation in which our individual perspective is primary. Consider a physical analogy that needs to be extrapolated to the socialconsider how when one is driving a car on the road (as opposed to say when one is walking on the road) we orient ourselves perceptually to the demands of the world ahead not from the point of view of one's own individual body (as one does when one is walking on the road) but from the point of view something larger than one's individual body, from the point of view of the whole car. That orientation when extrapolated from this physical or bodily example of the car to the social, should have a significant 
outcome. Even though it may involve the mentality and agency of individuals, because they each exercise their liberty in perceiving and responding from the point of view something larger, this non-individualistic orientation of each individual to the world (seeing the world's demands from the point of view of the collective), is bound to internally cohere with equality in its outcomes. For equality would on this picture not be seen as something extra or further that is conceptually configured as something to be navigated in terms of a trade-off with liberty, but rather as potentially built-into the deliverances of the exercise of liberty itself, when the exercise of liberty is the exercise of a mentality in this form of unalienated agentive responsiveness to the normative demands of the 'world'. The point is not that liberty, so conceived, will actually deliver equality. It cannot be a sufficient condition in that way. The claim was never one of sufficiency. Other conditions are bound to be necessary to suffice for equality. The point rather is that it is no longer defined such that it needs to be in trade-off relations with equality, which was the conception of liberty that my dialectic invoking Gandhian considerations of alienation was devised to transform.

If all three notions, liberty, equality, and the unalienated life are triangulated in this way together, we have a notion of unalienatedness that is not the same as the one of pre-modernity with its absence of liberty and equality, and we have a notion of liberty that is not itself generative of inequalities unlike in the liberal framework where it is individualistically conceived (in the form that attaches to individual talent and property) but rather non-individualistically conceived in the way that I have just very briefly outlined.

\section{An Unalienated Way of Thinking}

With the centrality given to the ideal of an unalienated life, a crucial thing that such a revised framework yields is that it is now quite impossible to even so much as raise the difficulties that lead to the tragedy of the commons. If what I have just drawn together from Gandhi's seemingly miscellaneous strands of philosophical claims are right, to even so much as have the qualm and raise the question, "Would my efforts and contributions to the collective cultivation (or restraint from over-cultivation) be wasted if others don't also contribute?' is already to be thoroughly alienated, by the lights I have set up in the ideal of the unalienated life I have just presented. When the society is unalienated in this sense, it does not occur 
to one to question that others may not be like one in seeing the world's demands in the requisite way I mentioned above.

Spare me the indulgence of relating an anecdote of an experience with my father in my pre-teen youth that I have recounted in an early essay of mine on Gandhi. ${ }^{10} \mathrm{He}$ would sometimes ask that I go for walks with him in the early morning on the beach near our home in Bombay. One day while walking we came across a wallet with some rupees sticking out of it. My father stopped me and said somewhat dramatically, 'Akeel, why shouldn't we take this?' And I said sheepishly though honestly, 'I think we should take it'. He looked irritated and said in response, 'Why do you think we should take it?' And I said, what is surely a classic response, 'because if we don't take it, somebody else will'. I expected a denunciation, but his irritation passed and he said: 'If we don't take it, nobody else will'. I thought then that this remark had no logic to it at all. Only decades later when I was thinking of questions of alienation did I realize that what he might have had in mind is the assumption of an unalienated framework of thinking. It is the assumption behind the thought 'If we don't take it, nobody else will' that expresses that unalienatedness.

I want to stress the relevance here of the remarks I began with in Gandhi about how alienation is reflected in the detachment or disengagement in our social relations. Because that is so, it becomes clear that the expression, 'nobody else will' in my father's response cannot be expressive of unalienatedness if it is interpreted as a prediction of what others will do. When we predict what others will do we relate to them from a disengaged perspective. That is the perspective that pervades alienated social relations. In fact it is only when we view others from this perspective that we are prompted to ask the question that drives the tragedy of the commons, 'What if I paid the cost of cooperation and others didn't?' And my invoking my father's remark was precisely to point to something in it that is quite different from this perspective. From a detached perspective, what my father said might seem like naïve optimism about what others will do. But even to raise the question of optimism (or realism) is to view his remark ('nobody else will') as a prediction made from a detached perspective on others. That misses the point I am making in invoking it. The assumption that others will not take the wallet if we don't is not made

${ }^{10}$ Akeel Bilgrami, "Gandhi, the Philosopher," Economic and Political Weekly, Vol. 38, No. 39, 27 September 2003. 
from that detached point of view. It is an assumption of a quite different sort, more in the spirit of 'let's see ourselves this way', an assumption that is unselfconsciously expressive of our unalienatedness, engaged with others and the world, rather than assessing the prospects of how they will behave in a disengaged mode.

To return to the perceptual understanding of our normative responses, if each commoner in exercising his liberty or self-governance is seeing the world's normative demands right, seeing it from the non-individualistic perspective, a perspective larger than her own, the question that leads eventually to the tragedy, ('Should I contribute the costs of cooperation if others don't?') is simply silenced or preempted. Or, to approach it from the other side and invoke the analogy I gave earlier, to ask that question is analogous to seeing the road ahead from the point of view of your own body rather than from the point of view of the car. The tragedy of the commons is, then, like the tragedy of a car crash, something you land in when you have an alienated (motor-unworthy) perspective on the world. And something like the conceptual shift of the kind that radically revises what is central among our political ideals and places the unalienated life on centre stage is what allows you to see self-governance and liberty along these lines which will help preempt the tragedy.

To be unalienated is to be free of a certain malaise, but since that malaise gets a rather abstract description, to be 'unalienated' itself must be understood in relatively abstract terms. It is not to have sympathy for or feel fraternity (that is why I did not choose 'fraternity' and chose the 'unalienated life' as my central ideal) with others or to show solidarity towards others, good though it is to have and do that-not all good things are the same good thing! Rather, it is to be free of a way of thought in which, when we make the decisions we make in governing ourselves as individuals in the exercise of our liberty, we do not so much find it wrong as we find it never occurring to us to have the qualm in question that leads to the tragedy-suggesting that game-theory itself may be a higher-order symptom of our alienation. And to be free of that way of thought is simply (well, 'simply' is an ostentatious bit of rhetoric here) the other side of a fitting phenomenology of value. To see the world and its value properties that make normative demands on us aright and to overcome alienation are not two things but one.

I have spent a long time in presenting a no doubt unnecessarily elaborate set of considerations to establish the case against a liberal political and economic point of view (from Locke's contractualism through to 
contemporary defences of it via arguments regarding the tragedy of the commons) that seeks to establish both the rationality and therefore the historically progressive necessity of a deeply set privatized form of capital that Amartya Sen's remark, with which I began, invokes. One answer to the updating of Locke by this tragedy of the commons argument for the rationality of privatization, I have argued, is via a proper understanding of the centrality of the ideal of unalienated life that is on offer in Gandhi's political philosophy. Such an answer, if right, may have the merit of showing the entire set of assumptions that are expressed in Sen's remark to be uncompulsory.

\section{BIBLIOGRAPHY}

Bilgrami, Akeel. "Gandhi, the Philosopher." Economic and Political Weekly 38, no. 39 (27 September 2003).

Hardin, Garret. "The Tragedy of the Commons." Science, 13 December 1968.

Jacob, J. R. Robert Boyle and the English Revolution. New York: Burt Franklin and Company, 1977.

Kuhn, Thomas. The Structure of Scientific Revolutions. Chicago: University of Chicago Press, 2012.

Locke, John. Second Treatise on Government. Mass Market Paperback Publishing, 2008.

Marx, Karl. On the Jewish Question. In The Marx-Engels Reader, edited by Robert Tucker. New York: Norton, 1978.

Ostrom, Elinor. Governing the Commons. Cambridge: Cambridge University Press, 2015.

Schaffer, Simon. "The Earth's Fertility as a Social Fact in Early Modern England." In Nature and Society in Historical Context, edited by Mikulas Teich, Roy Porter, and Bo Gustafsson. Princeton: Princeton University Press, 1997.

Sen, Amartya. "Prohibiting the Use of Agricultural Land for Industry Is Ultimately Self-Defeating." The Telegraph (Kolkata), 23 July 2010. 
Open Access This chapter is licensed under the terms of the Creative Commons Attribution 4.0 International License (http://creativecommons.org/licenses/ by $/ 4.0 /$ ), which permits use, sharing, adaptation, distribution and reproduction in any medium or format, as long as you give appropriate credit to the original author(s) and the source, provide a link to the Creative Commons license and indicate if changes were made.

The images or other third party material in this chapter are included in the chapter's Creative Commons license, unless indicated otherwise in a credit line to the material. If material is not included in the chapter's Creative Commons license and your intended use is not permitted by statutory regulation or exceeds the permitted use, you will need to obtain permission directly from the copyright holder.

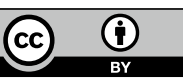




\title{
Consumerism in Contemporary China
}

\author{
Karl Gerth
}

Why have the values of consumerism become predominant in the contemporary world? This chapter explores the rise of consumerism through the recent history of China and the spread of its defining value-you are what you consume-through two related arguments. First, consumerism is embedded in industrialization itself. Second, consumerism has not spread spontaneously. The history of China since the Communist Revolution in 1949 suggests that every industrializing state, whether "capitalist" or "socialist," has played a critical role in spreading consumerist values. Political economies around the world-even "socialist" ones-have helped spread consumerism over many decades. Because humans and their institutionsnot "human nature"-create consumerism, the possibility of promoting non-consumerist values such as egalitarianism, civic mindedness, and spirituality exists. However, the history of consumerism also reveals itself to be a formidable foe to such alternative values. ${ }^{l}$

Modern consumerism spread as part of industrialization. Industrialization and consumerism have depended on each other. Observers often

${ }^{\mathrm{l}}$ For providing a forum and critical commentary, the author thanks Tanweer Akram and the other participants at the conference, "Faith and Finance," the University of St. Thomas, Minneapolis (July 25, 2018).

K. Gerth $(\bowtie)$

Department of History, University of California, San Diego, CA, USA

(C) The Author(s) 2020

T. Akram and S. Rashid (eds.), Faith, Finance, and Economy, https://doi.org/10.1007/978-3-030-38784-6_5 
overlook this dependence. Modern history usually focuses on the production side of this relationship: how people used new technologies and fossil fuels to improve productivity and expand production, that is, how countries industrialized. Studying consumerism shifts the traditional focus from production to consumption, from the supply side to the demand side of industrialization. Endless demand for mass-produced things has been assumed by historians who have focused on industrialization as a story of overcoming the limits of production with fossil fuels and new technologies. But a simultaneous expansion of demand alongside production had to occur. Industrial capitalism needed people (reconceptualized as "consumers") to want newer and more products. The history of consumerism explores the challenge of getting people to value learning about and attempting to acquire ever-more things. ${ }^{2}$ To give one example, modern advertising became "modern" because it relied heavily on images and implied stories rather than text and information. ${ }^{3}$ Advertising informed "consumers" not simply that a given product existed and had various specific uses but rather that acquisition of a product allowed one to construct and communicate an identity through its consumption. Consumerism valued the use of things rather than, say, actions or relationships to tell the world (and oneself) who one is.

Supporters of consumerist values emphasize how the consumption of things enables self-expression and empowerment, what scholars refer to as "agency." To invoke a famous US advertising slogan, one could "be like Mike" (basketball star Michael Jordan) if they chose to buy a brand of sugary colored water (Gatorade) or, to cite another popular commercial trope, if a male drank a certain brand of beer he would be more attractive to the opposite sex. The power of consumerism has been its ability to make multiple identities possible through consumption, even those associated with anti-consumerism, such as environmentalism. One could, for instance, choose to communicate "I am an environmentalist" not just by

${ }^{2}$ On the long-term, global rise of consumerism, see the edited volumes and work of Frank Trentmann, particularly his wide-ranging study (2017) Empire of Things: How We Became a World of Consumers, from the Fifteenth Century to the Twenty-First. London: Penguin Books.

${ }^{3}$ This interpretation of the role of modern advertising comes from Sut Jhally. 2016. Codes of Advertising: Fetishism and the Political Economy of Meaning in the Consumer Society. New York: St. Martin's Press. 
hugging a tree but by driving a hybrid Prius rather than a gas-guzzling Hummer.

Critics contend that consumerism creates a narcissistic culture. ${ }^{4}$ Rather than personal empowerment, consumerism undermines self-confidence and self-worth by teaching people to focus on a never-ending list of personal faults that, once recognized, must be corrected through informed consumption. ${ }^{5}$ Expressing values becomes an exercise not done through social deeds aimed at improving the collective good but rather by fulfilling individual needs and desires through commodified things and experiences. Everything shifts toward values mediated by consumerism across all areas of life, including areas seemingly antithetical to consumerism. As the CEO of one religiously affiliated financial company observed, people are taught to interact with their churches not as members of a community but rather as "consumers." They then begin to fix the problems of their church not as co-members of a community but rather by finding a more suitable church, that is, by choosing a different product. ${ }^{6}$ The secular world of politics has seen similar transformations under consumerism. Rather than seeing politics through the lens of citizens who set the entire political agenda, residents of "democratic" countries have become consumers who select a political product. To add a third example of the ubiquity of consumerist values, college professors complain of the same: students see themselves as consumers who do the choosing rather than students to be educated.

While consumerism predates the industrial era that led to mass production, modern consumerism spread quickly starting in the late nineteenth century. ${ }^{7}$ Industrial production meant producers had to find new

\footnotetext{
${ }^{4}$ The classic expression of this interpretation comes from historian Christopher Lasch. 2018. Culture of Narcissism: American Life in an Age of Diminishing Expectations. New York: Warner Books.

${ }^{5}$ For a brief and accessible introduction to examples of sexist stereotypes used both to teach "faults" such as grey hair or skin blemishes and sell products for women to fix them, see http://www.dailymail.co.uk/femail/article-5463181/Vintage-ads-reveal-sexistcampaign-slogans.html. Accessed 8 August 2018.

${ }^{6}$ Brad Hewitt and James Moline. 2015. Your New Money Mindset: Create a Healthy Relationship with Money. iBook, no pagination. They write: "People show up less as worshipers or community members than as consumers. As soon as an engaging preacher leaves or a great musician moves on, the church down the road suddenly looks a lot better. That's a consumer mindset....".

${ }^{7}$ For an overview of the pre-modern history of consumerism, see John Brewer and Roy Porter, eds. 1994. Consumption and the World of Goods. New York: Routledge. On the
} 
ways to stimulate desire. State power in the form of imperial expansion help spread consumerism abroad by "opening" new markets. Imperialist powers taught inhabitants their countries were comparatively "backwards" and needed to "catch up." Overt military force as well as the subtler means associated with the introduction of mass-produced products taught this lesson of backwardness. Once they gained market access, foreign companies convinced populations to have new material needs and wants. Billions of dollars of advertising, for instance, flowed into new forms of mass media such as newspapers and radio. ${ }^{8}$ By the early twentieth century, advertising had shifted from focusing on the specific uses of a product (e.g., buy a bicycle to get to work) to the identities one could create and communicate to others through possessing things (e.g., possess a bicycle to communicate class, masculinity, and other attributes). ${ }^{9}$

The People's Republic of China (PRC) provides a good place to explore the history of the universal phenomenon of consumerism. The tension between consumerism and non-materialistic values is highly visible in contemporary China because the country started to industrialize relatively late and because since 1949, after the Communist Revolution, it claimed to be industrializing without "bourgeois" consumerism, as a country that was "building socialism." The rush to "catch up" with the dominant global powers led to both positive and negative outcomes. The positive side is well known: a record of leading hundreds of millions out of extreme poverty. But the explosive growth in the PRC also included a consumerism that created or exacerbated innumerable urgent crises: childhood obesity, extreme markets for body parts and endangered species, acid rain falling on $1 / 3$ of the country, and many other human

Chinese antecedents, see Craig Clunas. 1991. Superfluous Things: Material Culture and Social Status in Early Modern China. Champaign: University of Illinois Press.

${ }^{8}$ For general coverage of the spread of advertising, see Mark Tungate. 2013. Adland: A Global History of Advertising, Ed. 2. Philadelphia: Kogan Page. For a good example of how new technologies spread awareness and desire for products via advertising, see Steve Craig. 2009. Out of the Dark: A History of Radio and Rural America. Tuscaloosa: University of Alabama Press.

${ }^{9}$ For an account of one global company in China and the marketing techniques it introduced to cultivate desires, see Sherman Cochran. 1980. Big Business in China: SinoForeign Rivalry in the Cigarette Industry, 1890-1930. Cambridge: Harvard University Press. 
and environmental catastrophes. ${ }^{10}$ The PRC provides particularly striking evidence of how consumerism dominates the contemporary world.

The history of consumerism in the PRC also reveals consumerism as a formidable foe embedded in all industrial societies. Since the rise of modern consumerism in the late nineteenth century, nations and individuals have learned to compete through consumption. The compulsion to compete through consumption was part of the global political economy in both "socialist" and "capitalist" countries during the Cold War. Consumerism developed even during the time when Chairman Mao Zedong was the preeminent leader, from the establishment of the PRC in 1949 to his death in 1976 (hereafter, the Mao era). This chapter discusses the compulsion to adopt the values of consumerism and compete through consumption, including at the height of the Mao era, and the Chinese Communist Party's (CCP) efforts to create an alternative "socialist" culture. The reinterpretation of the Mao era as promoting rather than quelling consumerism contextualizes the last part of the chapter, an examination of how this state-led consumerism of the Mao era continued into the early 1980s, when the CCP shifted dramatically from attempting to suppress consumerism to promoting both private enterprise and "bourgeois" consumerism.

\section{The Compulsion to Consume}

The recent history of PRC reveals the power of consumerism to displace other values. After the Communist Revolution of 1949, CCP leaders claimed they were building a radical "New China", with a "New Society", which fundamentally broke with both the pre-1949 "Old Society" as well as global capitalism. ${ }^{11}$ The critical turning point was the victory of the CCP and the "liberation" of China in 1949. In official histories, the

${ }^{10}$ I cover the negative consequences of the post-1978 promotion of consumerism in Karl Gerth. 2013. As China Goes, So Goes the World: How Chinese Consumers Are Transforming Everything, Chapter 7. New York: Farrar, Straus and Giroux. Many other books detail individual crises. On the obesity epidemic that has accompanied expanding consumerism, see Paul French and Matthew Crabbe. 2010. Fat China: How Expanding Waistlines Are Changing a Nation. London: Anthem Press.

${ }^{11}$ Michael Schoenhals. 1992. Doing Things with Words in Chinese Politics: Five Studies. Berkeley: Institute of East Asian Studies, Center for Chinese Studies, University of California. 
Communist Revolutionaries "liberated" China from the domestic ("semifeudal") and international capitalist ("semi-colonial") forces that enslaved the country and kept China poor and weak. Consequently, the Socialist Revolution was not merely a violent power struggle between two contending political parties - the Nationalist Party (KMT) under Chiang Kaishek versus the CCP led by Mao Zedong. According to the revolutionaries themselves, the civil war was a conflict over two fundamentally different visions of how to transform China into a wealthy and powerful country: capitalism vs. socialism.

The idea that the PRC was building an anti-capitalist, anti-consumerist nation served both sides in the Cold War and still predominates in popular interpretations. Even academics and popular histories outside of the PRC conventionally echo the CCP language by framing the history around the embrace of socialism in 1949 and its transformation in 1978. ${ }^{12}$ Global populations learned to see China through the frame of socialism. Adversaries of the PRC and CCP abroad, led by the United States, reinforced the idea that 1949 was a revolutionary socialist (or "communist") break with the capitalist countries. Throughout the Cold War (and in some cases down to the present), politicians, scholars, and the mass media-in China and its adversaries-cast their differences as differences between antithetical world orders. ${ }^{13}$ "Communism" versus "capitalism" became the terms both sides used not only to describe their opposition but also themselves. Depicting the tensions between Cold War adversaries as battles between two completely different ways of life was as crucial for domestic cohesion and discipline as for the battle for the hearts and minds of the opposing populations. ${ }^{14}$

${ }^{12}$ Scholarly accounts almost universally emphasize these breaks. The same applies to college courses, which mostly begin in 1949 or end in 1978. There are a growing number of exceptions that question CCP formulations. See, for instance, Frederick Teiwes and Warren Sun. 2015. Paradoxes of Post-Mao Rural Reform: Initial Steps Toward a New Chinese Countryside, 1976-1981. New York: Routledge.

${ }^{13}$ For an illustration of these contrasting ways of life in the popular (US) imagination during the height of the Cold War, see the Armed Forces Information Film "Freedom and You," rereleased in 1962 as "Red Nightmare," which presents as an educational film of what American life in a small town would have been like under "communism." https:// www.youtube.com/watch?v=cgR4apcz_Ew. Accessed 21 July 2018.

${ }^{14}$ This theme is discussed in Oscar Sanchez-Sibony. 2014. Red Globalization: The Political Economy of the Soviet Cold War from Stalin to Khrushchev. Cambridge: Cambridge University Press, 9 n. 6 and throughout. 
Yet, even after the CCP came to power in 1949, decades of mass campaigns and state rhetoric vilifying "bourgeois" consumer desire as a threat to "socialist construction" not only failed to destroy consumerism but even helped spread it into new classes and places. Consumerism spread because all industrializing countries competed with each other and within themselves over both big and everyday technologies. Competition over the more capital-intensive "big technologies" was more conspicuous in the form of railroads, telegraphs, mining, large-scale irrigation, electrification, and, most importantly, national "defense" technology. Such competition between nations easily appears as vanity. In the twentieth century, big technologies became icons of national wealth and power. ${ }^{15}$ Having better technology (such as an atom bomb) became a measure of national success that conferred political legitimacy. Nations competed over big technologies as conspicuous measures of their success overcoming earlier "backwardness."

National wealth-and political power-depended on successful competition. Without big technologies the CCP could not compete against the British, Japanese, Americans, and smaller imperialist powers for both the latest and most necessary forms of national security and economic infrastructure. An atom bomb, which the PRC first exploded in 1964, became the clearest manifestation of competition over big technologies. ${ }^{16}$ Without an atom bomb and other big technologies, particularly weapons, the PRC would have faced even greater threats of military invasion. In effect, competition was compulsory. Likewise, without secure borders, imperialist powers would have continued to dominate the economy, as they had in the first half of the twentieth century. Big technologies were critical to specific forms of economic competition. They increased productivity and lowered transaction costs. New railroads, for instance, enabled PRC economic planners to move northwest coal to southeast factories, thereby making the latter more productive. Before and after the establishment of the PRC in 1949, Chinese leaders knew the country had to

15 The best-known book on this topic is: Michael Adas. 2015. Machines as the Measure of Men Science, Technology, and Ideologies of Western Dominance. Ithaca: Cornell University Press. On competition over big technology in China specifically, see Anne Reinhardt. 2018. Navigating Semi-Colonialism: Shipping, Sovereignty, and Nation-Building in China, 1860-1937. Cambridge: Harvard University Press.

${ }^{16}$ Joseph Cirincione. 2007. Bomb Scare: The History and Future of Nuclear Weapons. New York: Columbia University Press, 51. 
compete to create or acquire big technologies. Without those continual improvements, the PRC could not compete for markets and earn the capital needed for big technologies.

While military and economic rivals created a national compulsion to compete in big technologies, there was simultaneous competition over new "everyday technologies" that helped drive consumerism. These were less conspicuous and capital-intensive than big technologies, and included sewing machines, bicycles, timepieces, typewriters, radios, gramophones, cameras, rice mills, and a host of others. ${ }^{17}$ Mass-produced everyday technologies transformed all aspects of day-to-day life. In the process, they also helped introduce the idea of backwardness and, thereby, the compulsion to "catch up." Even without modern advertising designed to teach people about their inadequacies, the spread of these everyday technologies popularized a notion of individual backwardness that could only be overcome with the acquisition and mastery of mass-produced products, things one had to buy. The consequences of failing to acquire and master everyday technologies powerfully shaped identities and thereby increased the desire to possess things. The pride of knowing how to ride a bicycle or operate a sewing machine, particularly when few did, also provided a person or family with material advantages. Likewise, competition over knowledge and possession of everyday technologies recreated many of the inequalities the CCP claimed to correct: urban over rural; mental over manual; coastal over interior (and, later, male over female). Conversely, the lack of knowledge - much less possession — of everyday technologies generated shame that one had not mastered everyday technologies.

The national and individual compulsion to compete by possessing big and everyday technologies meant the stakes related to consumerism were - and remain-great. Since the start of industrialization in China in the late nineteenth century, high stakes have continually justified a much greater state role in managing consumption and consumerism, a realm of activity often thought to be about personal choice. In the realm of politics, "catching up" and overcoming relative backwardness has been a fight that helps justify CCP monopoly control over the state and, indeed, the necessity of a "socialist" country having a strong state. As with other countries struggling to overcome relative backwardness, the CCP has long

${ }^{17}$ The expression "everyday technologies" comes from David Arnold. 2013. Everyday Technology: Machines and the Making of India's Modernity. Chicago: The University of Chicago Press. 
considered as too risky the idea of letting the markets- free of state intervention-decide national and individual priorities. What if the market catered to the needs of the very wealthiest for, say, bigger yachts rather than national needs for domestically produced technology such as, figuratively speaking, an atom bomb? And, more recently, what if domestic consumers preferred a foreign-controlled social media website to a Chinese one?

While the state has been critical to shaping consumerism, the general population helped spread consumerism by turning what had been unimaginable luxuries in the decades before 1949 into everyday products. The three most highly sought-after products of the Mao era demonstrate the role of mass production in spreading consumer values in a "socialist" country. Beyond the basic necessities, people in cities, towns, and villages around the country most commonly desired what became known as the Three Big-Ticket Items ( san da jian, hereafter, the Big Three). The exact Three varied by time and place but most often included a wristwatch, a bicycle, and a sewing machine. ${ }^{18}$ Throughout the 1940s, all three were hard to acquire, usually manufactured by foreign-owned companies or imported, and only found in the homes of the better-off. As the domestic industry recovered from decades of war in the 1950s, for most people, even having any one of the three was an accomplishment. However, the trend over the course of the Mao era led to near-universal awareness, desire, or possession of the Big Three. CCP policies spread consumerism by making the Big Three increasingly available to people in cities, towns, and even parts of the countryside. By the end of the era, they had gone from being comparative luxuries to being so commonplace that the original Big Three were no longer considered extravagances. Consumerism continually expanded-alongside production-in the form of new desires. The Big Three of the 1980s became some combination of TVs, washing machines, electric fans, and portable cassette players. By the 1990s, people desired stereos, mobile phones, microwave ovens, refrigerators, and personal computers. And now the upwardly mobile dream of cars, apartments, leisure travel, and other more expensive things. And, of course,

18 Although those starting a new household often considered a sewing machine one of the essential Big Three items, some young people preferred a radio or a camera. Wool clothing was also sometimes described as one of the Big Three, especially as part of a betrothal gift. 
the growing consumption of these consumer goods have become a crucial aspect not only of consumerism but also new rounds of economic growth in China. ${ }^{19}$

Consumerism-the desire to communicate identity through the consumption or use of things-spread at the level of ordinary life thanks to the immediate practical uses as well as the broader social value of the Big Three. Demand grew because industrialization made the Big Three increasingly indispensable as labor-saving technologies, modes of transportation, and labor multipliers (i.e., the same amount of labor produced more products). ${ }^{20}$ The desire for watches, for instance, reflected the new discipline over time, particularly those working on highly time-dependent "factory time" rather than by the sunlight in agricultural fields. Individual ownership by factory workers, for instance, meant they could not only show up on time for work but also resist manipulation of a central clock by their employers. ${ }^{21}$ Likewise, bicycles symbolized the need for greater mobility, for instance, to get to a job or to transport agricultural products to markets. And sewing machines created opportunities to increase female productivity through sideline work. The broader social uses of the Big Three multiplied so fast and became so important for everyday life that acquisition and mastery became, in effect, increasingly compulsory. Everyday life pushed people to desire the Big Three for social uses such as bribes to officials, ways to store value after a good harvest, and even as enticements offered by parents to get their children to study harder for school entrance exams. Even toothbrushes and toothpaste taught new ideas of the body and hygiene: teeth required regular brushing-as well as class and urbanity - and those who did not know to brush their teeth,

${ }^{19}$ On the state role in promoting cars, including electric vehicles, see Karl Gerth. 2015. "Driven to Change: The Chinese State-Led Development of a Car Culture and Economy," in Atle Middledun and Nina Witoszek (eds.), Energy Transport in Green Transition: Perspectives on Ecomodernity. New York: Routledge.

${ }^{20}$ On farmers hoarding the Big Three, such as one that bought ten bicycles, see Ren Yuanhang, "Shucai diqi bufen nongmin zizhang langfei xianxiang" (The Phenomenon of Vegetable Farmers Overspending), Hangzhou Daily, 25 July 1957; and "Qian yao yong zai daokou shang" (Money Ought to Be Spent on the Blade), Hangzhou Daily, 22 August 1957. On bribing children with watches, see Guang Jun, "Hang Liu Zhong zhaokai jiazhang hui" (A Parents' Meeting in Hangzhou No. 6 Middle School), Hangzhou Daily, 27 March 1957.

${ }^{21}$ E. P. Thompson. 1967. “Time, Work-Discipline, and Industrial Capitalism.” Past \& Present 38: 56-97. 
much less actually brush them, were "backward." 22 Products enabled and created the social need to communicate something as taken-for-granted as "I know how to ride a bicycle" or "my family is prosperous and connected enough to acquire a sewing machine." Products and their social environments overrode "socialist" attempts to suppress consumer desire.

Perhaps the most important function of the Big Three came with every family wanting to marry off its young men to suitable women. Despite endless admonitions to keep weddings simple, throughout the Mao era and since, a bride's family expected even modestly well-off young men's families to provide at least one and ideally all Big Three at the time of betrothal. Failure to do so suggested that the groom was an undesirable match. This expectation-embodied in the concepts of "perfect match based on comparable standing" and "face" transcended the Socialist Revolution of 1949 and was so deep-seated in cities and villages that in some cases, the groom's family would borrow money to obtain the necessary items and pay off the debt after the marriage. The continued desire for specific products to assess and reinforce social differences underscores the impossibility of creating a "socialist" culture with values built entirely around self-sacrifice and austere "proletarian" uniformity egalitarianism. ${ }^{23}$

And competition was never-ending. In addition to the inflation of desires noted above, hierarchies based around brands further expanded consumerism. As industrialization and consumerism developed, not everyone was satisfied once they possessed one item or even a generic item in that category. One might want not just any wristwatch but only a Shanghai brand wristwatch or even the latest model, lest they feel ashamed by a dated or inferior model. In the eyes of some upwardly mobile Lower Yangzi delta residents, for instance, at one point, the height

${ }^{22}$ For an accessible overview of bodily practices such as brushing one's teeth that emerge in the late nineteenth century, see Ruth Goodman. 2015. How to Be a Victorian: A Dawn-to-Dusk Guide to Victorian Life. London: Viking. Henrietta Harrison covers some these topics for China in (2011) China: Inventing the Nation. New York: Oxford University Press.

${ }^{23}$ On the frustrations of rural cadres attempting to eradicate betrothal gifts in the first decade of the PRC, see Neil Jeffrey Diamant. 2000. Revolutionizing the Family: Politics, Love, and Divorce in Urban and Rural China, 1949-1968. Berkeley: University of California Press. 
of fashion was for a young person to ride a Forever bicycle, wear a Shanghai brand watch, and listen to a Red Lantern radio. ${ }^{24}$ "Socialist" countries such as China also witnessed the development of consumerism to include communication through branded products.

Of course, the proliferation of products did not spread uniformly. Consequently, the centrality of the values introduced by consumerism varied by place and time. A factory manager in Shanghai-where there were at least ninety well-known product brands by the end of the Mao erawould have had different experiences than a rural farmer. This factory manager, for instance, would have had greater knowledge of and desire for an Enicar imported Swiss watch than, say, a farmer in rural Guangxi province. ${ }^{25}$ While the manager would have had a greater need to participate directly in consumerism, many millions did not engage in much consumption, much less "consumerism." It is easy to imagine villages throughout China that during this period had little to do with communicating identity through buying things. The country was, after all, starting from a position of extreme poverty. Few rural residents-and not that many urban ones-dreamed of Enicar watches. Nevertheless, possession-or lack thereof-alone introduced new social cleavages in a country claiming to be building a more egalitarian country.

New forms of social differentiation based on knowledge about and desire for products spread faster and further than their acquisition. Countless tens of millions of urban and rural households across China-and in increasing numbers-began to learn about, desire, and even feel compelled to want and use everyday technologies. Even a very poor person with little chance of acquiring a bicycle or sewing machine might have seen the Big Three on street advertisements, witnessed them in a statemade movie projected by a traveling film team visiting their isolated village, been told they were mandatory to secure a bride, or encountered them in countless other ways. Awareness and desire predated possession.

${ }^{24}$ Huang Ji Zahuo Pu (blog name), "Zhongguo shoubiao wangshi” (The History of Chinese Watches), 20 June 2009. http://blog.sina.com.cn/s/blog_609daf0f0100eeft. html. Consulted 8 July 2017.

${ }^{25}$ Zhu Zhanliang. 1981. "Shanghai qinggongye mingpai chanpin chutan" (A Brief Analysis of Famous Brands Produced by Shanghai Light Industry). Shanghai jingji yanjiu 9(9): 7-11. 


\section{The Limits of State Consumerism}

Attempts by industrializing countries such as the PRC to define alternative values to consumerism such as socialist egalitarianism failed. Consumerism was more powerful than state efforts to limit or control it. Still, the CCP tried to manage consumerism not only because it posed a threat to its stated "socialist" values but also because consumer desire threatened the CCP's economic development strategy. Since 1949, the CCP has followed the example of other "late-comer" industrializing countries and attempted to accelerate industrialization by managing both the production side and the consumption side of the economy. In the view of the CCP, the need to industrialize and "catch up" as quickly as possible meant individual consumer choices were too important to national wealth and power to be left in the hands of impressionable, uneducated, or even unpatriotic individual "consumers."

While the CCP's role in organizing mass production is well-known, less known is its related role in managing demand. In this chapter, the term "state consumerism" represents the wide-ranging efforts within the PRC to eliminate, discredit, or at the very least marginalize what the CCP depicted as a chief threat to its control over how to spend, or allocate, its resources. The CCP attacked as "bourgeois consumerism" many of those challenges to state control over allocations, particularly those allocations that reinforced and communicated "capitalist" values of inequality, individualism, and exploitation through the desire for and acquisition of products and services. By contrast, state consumerism involved efforts led by the CCP to suppress or channel consumer desire, including by promoting a distinctive "socialist" consumerism and condemnation of "bourgeois" and "feudal" consumerism. In the Mao era, state consumerist policies to enforce these values included eliminating imports of "bourgeois" goods such as British Raleigh bicycles, Japanese Seiko watches, and American Singer sewing machines and limiting the amount and placement of advertising that might otherwise stoke undesirable consumer desire. ${ }^{26}$ The CCP also used its monopoly control over the mass media to equate an ethos of "hard-work and frugal living" (jianku pusu) with "socialism." Put more concretely, unbridled desire for, say, imported

${ }^{26}$ Edward J. M. Rhoads. 2012. "Cycles of Cathay: A History of the Bicycle in China." Transfers 2(2) (Summer), 95-120. 
watches-whether fulfilled at a state-run store or on the black marketmeant less capital for the state to allocate on national priorities such as the figurative atom bomb. Similarly, too much desire even for China-made watches created pressure of the state to allocate more scarce resources into consumer goods rather than producer goods.

The CCP goals of controlling production and consumption permeated Chinese society. Manifestations of a state-controlled economy "commanded" to be productive appeared everywhere, from Five-Year Plans to backyard steel furnaces to the mass mobilization of millions to turn barren land into cultivatable land or build bridges and tunnels. This preoccupation with developing the forces of production-capital accumulation-also permeated all aspects of everyday life and undoubtedly made it easier to overlook the spread of consumerism. Movies and literature lionized model workers such as Hao Jianxiu, a textile worker who invented methods to improve productivity and reduce waste; model farmers such as Wang Guofan, who figured out ways to increase harvests; and model soldiers such as Lei Feng, whose diary recorded his tireless efforts to serve the nation and do so voluntarily, without remuneration. ${ }^{27}$ Alongside "frugality," the CCP wanted people in the "people's republic" to work for free.

State consumerism was contentious. States often sought to impose limits on individual choice, a central pillar of consumerism, in the name of a higher ideology emphasizing collective goals such as "socialism" or "nationalism." Again, such attempts were not unique to China or even "socialist" countries and spread across the globe through national mass campaigns urging "patriots" to abstain from imports and buy products now cast as "domestic," "home," "native" or "national" products. ${ }^{28}$ In China,

${ }^{27}$ Lily Xiao Hong Lee, ed. 1998. Biographical Dictionary of Chinese Women. Armonk: M. E. Sharpe, 198-200; Jack Grey. 1973. Mao Tse-tung. Cambridge: Lutterworth Press, 46-47; and Miin-ling Yu. 2010. “Labor Is Glorious': Model Laborers in the People's Republic of China," in Thomas P. Bernstein and Hua-Yu Li (eds.), China Learns from the Soviet Union, 1949-Present. Lanham: Lexington Books.

${ }^{28}$ Because all industrializing states attempted to manage consumption, the secondary literature is vast. The swadeshi ("belonging to one's own country") and non-cooperation movements in India (1904-1908, 1920-1922) are the best-known and best-studied examples of such an application of nationality to products. Historians of late-colonial America have also emphasized the early links between consumerism and nationalism. For example, see Arthur M. Schlesinger. 1957 [1918]. The Colonial Merchants and the American Revolution, 1763-1776. New York: Frederick Ungar; and Timothy H. Breen. 2010. American Insurgents, American Patriots: The Revolution of the People. New York: Hill and Wang. 
before 1949, popular and state demands that individuals prioritize "national interests" over market prices, personal preferences, or other considerations were a tough sell. This is hardly surprising. Individuals often ignored or were ignorant of such demands. There was little the state, manufacturers of "Chinese products," or enthusiastic supporters of this form of nationalism could do to enforce a "patriotic" interpretation of consumer culture by ensuring Chinese people bought "Chinese products." 29

However, after 1949, the CCP finally had the power to impose the more autarkic economic vision developed in earlier decades, to add much more "state" to state consumerism. Rather than simply hoping popular campaigns might determine "patriotic" preferences, the CCP could now also impose nationalistic consumption with the same macroeconomic tools used in various market capitalist economies-tariffs on trade, exchange controls on hard currency, and outright bans on imports. Despite the official hostility toward things such as American nylon stockings or Hollywood films, and the difficulty of finding them, consumers actually still favored such imports over domestic goods and sought them out in the name of comfort, fashion, or other personal reasons. But consumers in late-industrializing countries such as China often preferred less expensive, higher-quality, heavily advertised imports, a consumer preference directly at odds with state goals to exercise more control over capital allocations and develop domestic industry.

Ultimately, individual consumerist desires generated in industrial society proved impossible to dictate. Attempts to replace "bourgeois" consumerism with state control were more aspirational than actual. The CCP's inability to control demand is predictable. After 1949, workers took the victorious CCP at its word that the Revolution inaugurated "the dictatorship of the proletariat." Contestations arose between the CCP, which wanted to allocate the surplus for collective "national needs," and workers and farmers, who usually had their own priorities. Workers and

Such "Buy American" campaigns are so numerous in American history that there is a survey of such attempts across the entire history of the US. See Dana Frank. 1999. Buy American: The Untold Story of Economic Nationalism. Boston: Beacon Press; and Lawrence B. Glickman. 2009. Buying Power: A History of Consumer Activism in America. Chicago: The University of Chicago Press.

${ }^{29}$ On China's attempts to link consumption and nationalism, see Karl Gerth. 2003. China Made: Consumer Culture and the Creation of the Nation. Cambridge: Harvard University Press. 
farmers fought for greater control, both directly by demanding higher pay and indirectly by pilfering the fruits of their labor. Farmers wanted to keep more of the harvest; workers wanted higher pay to buy more food, better housing, and various consumer goods. ${ }^{30}$ Thus, immediate crackdowns on labor strikes and institutionalization of long-term forms of control such as state-run labor unions were actually attempts to suppress competing demands over the surplus and its allocation into more consumption.

Even CCP leaders remained ambivalent about consumerism. The consumerism of the pre-1949 era was rarely completely vilified or discredited. In China and throughout the Communist Bloc, earlier forms of consumerism persisted in ways such as branded products and the identities associated with them, often despite explicit state attempts to end or limit them and, surprisingly, sometimes with state support. Recent research on Eastern Europe and the Soviet Union has uncovered consumerism thriving behind the Cold War propaganda that has often obscured such aspects of everyday life in Socialist economies. ${ }^{31}$ In line with such scholarship, an examination of not only the persistence of but also the further spread of consumerism in the PRC challenges the still pervasive assumption that the country was a realm of pure asceticism, without room for any consumer desire. Indeed, this assumption of "socialist asceticism" has led scholars to write off black market and other "capitalist" activity as unexpected and exceptional. $^{32}$

Mao Zedong and many Communist leaders were often openly hostile toward the consumerism associated with urban, "bourgeois" lifestyles.

${ }^{30}$ Most recent studies on urban and agricultural work now emphasize contestation between workers and the state. See, for instance, Elizabeth Perry and Li Xun. 1997. Proletarian Power: Shanghai in the Cultural Revolution. Boulder: Westview Press.

${ }^{31}$ There is a burgeoning literature on the tensions created by consumerism within "socialist" countries, particularly in the German Democratic Republic. Helpful studies include the relevant chapters on East German advertising in Pamela E. Swett, S. Jonathan Wiesen, and Jonathan R. Zatlin, eds. 2007. Selling Modernity: Advertising in Twentieth-Century Germany. Durham: Duke University Press, especially the chapters by Anne Kaminsky and Greg Castillo. For an overview on the role of consumer politics in the (de-)legitimization of Communist Party rule in Eastern European states, especially as these states failed to keep up with the market capitalist Joneses in Western Europe, see Mark Pittaway. 2004. Eastern Europe, 1939-2000. London: Hodder Arnold.

32 This emphasis on the asceticism of the Mao era is common in popular accounts. See for instance, Frank Dikötter. 2017. The Cultural Revolution: A People's History, 19621976. New York: Bloomsbury Press. 
But from its first decades forward, the People's Republic reshaped consumerism in Chinese life, especially in charged political times when even more common commodities were labeled "bourgeois"-but never eliminated it. China continued to mass-produce branded goods, and commodities remained objects of everyday discussion as well as markers of personal and collective identities. It was relatively easy for the state to suppress supply and limit economic incentives (such as higher pay) in state-controlled industry, commerce, and agriculture but much harder for it to control desires. The state could (and did) elect not to manufacture enough bicycles, sewing machines, wristwatches and other consumer goods to meet desire. But it could not prevent people from learning about and desiring these things. And unfulfilled desire had consequences, including the inability of the state to control the economy. By the late 1970s, the CCP decided it needed to harness market capitalism and "bourgeois" consumerism for its own political and economic ends. Leaders such as Deng Xiaoping decided that the PRC could industrialize faster by stimulating markets and consumerism than by suppressing them.

\section{Official Embrace of Markets and Materialism}

Even after the end of the Mao era and the official sanctioning of markets and consumerism starting in the late 1970s, the state continued to play a critical role in spreading consumerism. Consumerism did not develop after the Mao era as a natural phenomenon that occurs anytime a state withdraws from interfering in the economy. Rather the CCP implemented specific policies that shifted the organization of production (work) and consumption (leisure) in ways that promoted consumerism. Above all, private enterprise led to more consumerism. And vice versa: more consumerism led tens of millions to seek non-state opportunities to make money to buy the things they needed for immediate uses as well as broader social uses.

In 1978, the CCP led by Deng Xiaoping officially sanctioned a major transformation of society as well as the PRC's relations with market capitalist countries, known as the "market reforms and opening" or simply "the reform era." 33 Leaders once again permitted small private plots

${ }^{33}$ Many works discuss the economic dimension of these policies, including Joseph Fewsmith. 1994. Dilemmas of Reform in China: Political Conflict and Economic Debate. 
for agricultural production and small-scale private enterprises. ${ }^{34}$ Millions of farmers began to have much more disposable income to buy the Three Bigs and fulfill new desires. Likewise, millions of "self-employed, household-run businesses," known as getihu, popped up following the policy changes at the top. Entrepreneurs established everything from dumpling stalls to interprovincial agricultural produce transport. Like their counterparts in farming, getihu suddenly had disposable income. Mom-and-pop shop proprietors changed China in their capacity as highly touted leading consumers in the mass media and popular imagination. Getihu became the figurative Joneses that other Chinese wanted to catch up with. Although the vast majority of getihu remained poor, their desires, and the unintended consequences of their struggles to fulfill those desires, transformed China in the 1980s.

Beginning in the 1970s, millions of new getibu became a primary force spreading consumerism. ${ }^{35}$ Statistics confirm the spread. In 1978, there were only 150,000 private businesses; a decade later, there were more than 14 million getibu. ${ }^{36}$ These numbers grew so fast in part because legalization of getihu effectively recognized - and attempted to regulateprivate economic activity that was already occurring. ${ }^{37}$ In contrast to the Mao era rhetoric of "socialist equality," in which displays of wealth were at times deemed crimes against the state or, at the very least, an indication of "thought problems," this accelerating privatization of the economy symbolized by the spread of getibu immediately produced new classes of

Armonk: M. E. Sharpe; Barry Naughton. 1995. Growing Out of the Plan: Chinese Economic Reform, 1978-1993. Cambridge: Cambridge University Press; and Carl Riskin. 1987. China's Political Economy: The Quest for Development Since 1949. Oxford: Oxford University Press.

${ }^{34}$ On local restoration of private plots without state authorization, see Kate Xiao Zhou. 1996. How the Farmers Changed China: Power of the People. Boulder: Westview Press.

${ }^{35}$ Susan McEwen. 1994. "New Kids on the Block." China Business Review 21(3) (MayJune): 35-39. On the consumption side of getibu activity, the sociologist Thomas Gold has written several articles on getihu based on personal observation. See, for instance, Thomas B. Gold. (1991). "Urban Private Business and China's Reforms," in Richard Baum (ed.), Reform and Reaction in Post-Mao China: The Road to Tiananmen. New York: Routledge, 84-103.

${ }^{36}$ Susan Young. 1995. Private Business and Economic Reform in China. New York: Routledge, 6.

37 Ole Bruun. 1991. Business and Bureaucracy in a Chinese City: An Ethnography of Private Business Households in Contemporary China. Berkeley: Institute of East Asian Studies, 48 . 
relatively prosperous Chinese who demanded Coke, Pierre Cardin shirts and countless other new and foreign consumer goods. ${ }^{38}$ Of 1490 getibu households in a single district of Tianjin by 1984, for example, 946 had acquired televisions, 433 cassette recorders, 90 refrigerators, and 48 motorcycles. ${ }^{39}$

Getihu were not alone in their consumerism. Over the first two decades of the "reform era," CCP policies, as the state mass media popularized, that "allowed for some to get rich first" and have higher incomes created different classes of newly prosperous and wealthy consumers. ${ }^{40}$ After rural workers, the first group to appear was the small-scale household entrepreneur (the getibu). As many of the 17 million young people "sent down to the countryside" before and during the Cultural Revolution decade (1966-1976) returned to Chinese cities seeking work, the Chinese government officially recognized that massive urban unemployment had to be addressed, but it was not prepared to allocate massive state resources to solve the problem. In February 1979, the Central Committee of the CCP approved a report by the State Administration for Industry and Commerce that advised the central government to allow unemployed people with urban "household registrations" to start their own private businesses, but restricted such businesses to repair, services and handcrafts. Initially, as leaders felt ambivalent about abruptly reembracing private enterprise, getihu were forbidden to hire workers, a restriction that was quickly ignored and gradually changed as the range and size of private businesses expanded. ${ }^{41}$ Virtually every business surveyed

${ }^{38}$ See Andrew Walder. 2015. China Under Mao: A Revolution Derailed. Cambridge: Harvard University Press, 331. As he notes, China was the most inegalitarian socialist country in the 1970s, with a Gini coefficient of 0.33 .

${ }^{39}$ Marcia Yudkin. 1986. Making Good: Private Business in Socialist China. Beijing: Foreign Languages Press, 30.

${ }^{40}$ For an overview of the policies and their effects on income and consumption, see Karl Gerth. (2011). "Lifestyles of the Rich and Infamous: The Creation and Implication of China's New Aristocracy," in special issue of Comparative Sociology 10(4): 488-507; and Xiaowei Zeng. 2008. "Market Transition, Wealth and Status Claims," in David S. G. Goodman (ed.), The New Rich in China: Future Rulers, Present Lives. London: Routledge, 53-70. For the larger context, see Martin Hart-Landsberg and Paul Burkett. 2005. China and Socialism: Market Reforms and Class Struggle. New York: Monthly Review Press.

${ }^{41}$ Chen Guanren. 2005. “'Wenge' you Zhongguo shoujia siying fandian: Yuebin fandian" (Yuebin Restaurant, the First Privately Owned Restaurant in China After the 'Cultural Revolution'), initially published in Zhongwai shu zhai 3, 32-35, www.zwszzz. com/DCFB/bkview.asp?bkid=191395\&cid=630477; and Dorothy J. Solinger. 1984. 
in Chengdu in the late 1980s had employees that were not, as they were required to be, registered. Such "employees" seldom included workers hired off the streets but rather were neighbors, distant relatives, and former co-workers. By 1985, getihu numbered nearly 10 million. Roadside bicycle-repair shops, food stalls, and fruit vendors appeared everywhere. In the countryside, home to three-fourths of these new enterprises, individuals set up fishing ponds, restaurants, repair shops, and other small businesses. ${ }^{42}$ Moreover, as limits on the number of allowable employees expanded, so did the numbers employed in the private sector, reaching more than 18 million by $1988 .{ }^{43}$

In their quest for better lives, individuals did not always wait for state permission. Many private businesses opened without permission, sometimes with encouragement from local officials authorized to experiment by allowing limited getihu activities. ${ }^{44}$ Or, local officials simply looked the other way, recognizing there was little they could do or wanted to do. As Chen Shouzhu, then an officer working for the Wenzhou Industrial and Commercial Bureau recalled, officers routinely blew a whistle to alert peddlers gathered at an open market that they were going to check for paperwork, giving them time to flee the area without fine or arrest. Chen also recounted a case of a woman selling dried shrimp in a local market in Wenzhou. When the police came, she attempted to commit suicide by throwing herself into Nine Mountain Lake. Local cadres such as Chen took this as a sign of the desperation of the jobless workers operating private businesses. Later that year, Zhejiang province officially

"Commerce: The Petty Private Sector and the Three Lines on the Early 1980s," in Dorothy J. Solinger (ed.), Three Visions of Chinese Socialism. Boulder: Westview Press, 73-111.

42 Bruun, Business and Bureaucracy, 62.

${ }^{43} \mathrm{Wu}$ Nan (2011) summarizes the trends and statistics for the establishment of getibu in, "Gaige kaifang hou de xiahai jingshang yanjiu" (A Study of the Trends of Going into Business After the Start of the Reform and Opening Era) (M.A. thesis, Liaoning University).

${ }^{44}$ The role of local officials in implementing these policies ahead of state authorization is explored in many places, including Jonathan Unger. 2002. The Transformation of Rural China. Armonk, NY: M.E. Sharpe; Edward Friedman, Paul G. Pickowicz, and Mark Selden. 2005. Revolution, Resistance, and Reform in Village China. New Haven: Yale University Press; and Marc Blecher and Vivienne Shue. 1996. Tethered Deer: Government and Economy in a Chinese County. Stanford: Stanford University Press, 63-85. 
allowed Wenzhou to start a pilot getibu program and the area became a national leader in private enterprise. ${ }^{45}$

Early getihu proprietors often were reluctant to entangle their businesses with the state and obtain licenses, worrying that once licensed, official approval could be reversed and getihu activities cited as evidence that they were a "capitalist tail," a common insult leveled against anyone engaged in private commerce in previous decades. Consequently, the CCP worked hard to change the perception of getihu from reviled "tails of capitalism" to "national labor heroes." Ye Yongguo, for instance, started his business in 1982, when he was 22, by renting a stall in Huncheng East Road in Wenzhou, where he sold women's clothing. As with so many other getihu, he felt embarrassed to be a petty businessperson. When acquaintances approached his stall, he hid and had his mother work the stall until they left. Yet a year later, in 1983, he was named a "National Advanced Individual Worker" for his successful business. Newspapers and radios broadcast his story for over a month. By the end of 1983, there were over 80,000 getihu in Wenzhou alone. ${ }^{46}$

The CCP played a supportive role by using state-run media to celebrate countless other getihu. The case of the first authorized getihu in Hangzhou, a young woman who worked as a photographer at a famous tourist site, demonstrates the critical support given by the state and the ways private businesspeople influenced China in the early 1980s. The photographer's case also uncovers one of the many difficult transitions underlying the shift from the "socialist" to the "postsocialist" era. The state was involved in determining the shape and pace of these transitions. Hence, despite the rhetoric, this and millions of other getibu cases were not simply "David vs. Goliath" stories of hardworking getihu pitted against corrupt state-owned enterprise employees. Rather these cases also represent the state shifting sides to favor the non-state economy, a shift that encountered some popular and bureaucratic resistance. The spread of getibu, then, also tells the story of the erosion of "socialism," which had featured the near absence of private enterprise since the late 1950s,

${ }^{45}$ You Chengyong, Xiao Xinhua, and Wang Danrong, "Wenzhou getihu: shichang xianxingzhe-huayuan Zhongguo diyi dai getihu de neiduan lishi" (Wenzhou getihu: Market Pioneers-The History of China's First Generation of getibu). Wenzhou ribao, 7 July 2008.

${ }^{46}$ You Chengyong, Xiao Xinhua, and Wang Danrong, "Wenzhou getihu." 
and the creation of its replacement, first with getihu and later by stateconnected ("crony capitalism"), state-owned enterprises ("state capitalism"), and multinational corporations.

State sanctioning of getihu was a practical policy implemented to find work for the millions of youth waiting for state-provided work assignments and "sent-down youth" (also known as "educated youth" or by the Chinese term, zhiqing) returning to Chinese cities from the countryside. The most practical dimension of the policy: millions of such youth found work with little state assistance and without needing the state to underwrite their jobs. In such accounts, the state allowed private business; people seized the opportunity. But the state indirectly led people to become getihu by narrowing their options. This was the case for Hangzhou's first getibu. The state effectively limited Gan Jing's options by propagating social castes based on family backgrounds that made it more difficult for her to find a job within the state sector. ${ }^{47}$ Gan's father had been an architect in Indonesia in the 1950s and, along with his Indonesian-born ethnically Han Chinese wife, responded to the call to ethnic Chinese to help build New China. Shortly after moving to China, however, they were classified as "Rightists" and relocated to Manchuria to log forests. Toward the end of the Cultural Revolution decade, they returned to Zhejiang Province. Gan Jing, who was born in Dalian in 1960 while her father was working as a lumberjack, remained in China with her paternal grandparents. ${ }^{48}$ She was also hurt during the Cultural Revolution after neighbors mistook the sound of her grandmother using a sewing machine to mend clothing at night as a telegraph transmitting secret messages overseas. Her father was labeled a counter-revolutionary and locked up in a makeshift prison at Yuyao Longquan Mountain in Zhejiang province for 56 days. As a consequence of her family's political troubles, when it came time to go to university, she had to pick a less popular major, settling on the study of tourism at Zhejiang University. When she graduated in the summer of 1978, she could not find a state work unit willing to employ someone with her family background. So she went back to Dalian and lived with

${ }^{47}$ Wang Qiuhang. 2015. "Yihuang sanshi nian, fangfu jiu zai yanqian” (Everything Still Remembered Vividly After 30 Years). Lao Zhaopian 99: 73-83. Shandong: Shandong huabao chubanshe, Issue 99, 73-83.

${ }^{48}$ Wen Dao interview of Gan Jing, "Hangzhou diyiwei getihu" (The First getihu in Hangzhou). Hangzhou ribao, 16 March 2016. http://hzdaily.hangzhou.com.cn/hzrb/ html/2016-03/16/content_2217432.htm. Consulted 16 April 2017. 
relatives, where she apprenticed herself at a state photo studio for a year, returning to Hangzhou in early 1981 with her honed photography skills.

The state also indirectly encouraged Gan Jing and millions of other unemployed youth to consider becoming getihu by using state-controlled media to praise the new policies and provide successful role models. ${ }^{49}$ Gan herself first read such stories in local newspapers in the spring of 1981. And the state also directly intervened in her decision-making. Gan and other unemployed youth were reluctant to test the policy locally, fearing police harassment, social stigma, and, above all, removing themselves from the queue for state jobs and benefits at a time when few voluntarily abandoned the state sector. ${ }^{50}$ Although she knew about the getibu policy, it took visits to her house by officers of labor department and industrial and commercial department, who were encouraging such unemployed youth to apply to be getihu. Gan Jing started work easily enough, borrowing 200 yuan and bought a Seagull brand camera and, on November 13, 1981, obtained the first getihu license and badge in Hangzhou. Gan Jing recalled that because she was the first and because she was a woman, the cadres, who needed to recruit other getibu, looked after her, making her registration easy. Moreover, the Tax Bureau gave her a tax holiday for her first year, an important concession and signature way officials favored private - even foreign - over state enterprises throughout the postsocialist era. Others followed, including the second and third getibu in Hangzhou, also young female photographers. ${ }^{51}$

To be sure, the Chinese state played a critical role in the early days of creating openings for getibu and simultaneously undermining the economic and social place of employees at competing state-owned enterprises. In other words, the state not only passively "let" some get rich first, state representatives at all levels - from Deng down-actively implemented policies and, at times, intervened in local squabbles to ensure the success of actual getihu. State support of getihu was essential to their success.

49 There were, of course, countless other "Gan Jing's" lauded by the state. For a collection of similar success stories, see Wang Lingxu, ed. 1993. Ziyou guodu: gongshang getibu shenghuo jishi. Shanghai: Shanghai Academy of Social Sciences Press.

${ }^{50}$ See also the case of Zhang Huamei, the first getihu in Zhejiang Province, who had earned a fortune but was still ashamed of being a getihu.

${ }^{51}$ Wen Dao, "Hangzhou diyiwei getihu." 
Sanctioning getibu became a new way for the CCP to continue to shape and endorse consumerism. As over ten million "educated youth" (zhiqing) returned to Chinese cities from their rustication, joining the already swollen ranks of those waiting years for government-assigned jobs, allowing very small-scale private enterprise in the form of getihu was an inexpensive fix. In addition, getibu filled innumerable holes in the Chinese economy, particularly in basic services ranging from bicycle repairs to restaurants and food stalls. Moreover, a getihu from Shenyang claimed that his produce transport business preempted social problems associated with food price spikes. For instance, in 1987, the price for green peppers doubled in local markets. One enterprising getihu quickly sourced several tens of thousands of the vegetables from Guangdong and Guangxi provinces, on the other side of the country, which reduced the price below its pre-spike price. ${ }^{52}$

Getihu spread consumerism locally as symbols of the advantages of "market reforms" and the justification for further market policies such as the expansion of the private economy at the expense of the statecontrolled economy, whether in the privatization of state-owned enterprises in the cities or in the disbanding of agricultural communes in the countryside. While the vast majority of getibu did not get rich quickly (or at all), in the state-controlled mass media and the popular imagination, getihu became symbols of a surefire pathway to consumer plenty. This shift had political implications critical for understanding the transition to the post-Mao "reform era." Blame for individual economic problems such as unemployment or lack of ability to buy the Three Bigs-and responsibility for solving these problems - shifted onto an individual and his or her relationship to markets rather than to the state and its handling of the economy. The CCP endorsed a message that said, in effect, if you cannot find a job and therefore cannot afford the things you desire, use your own initiative and find your own source of income such as selling homemade dumplings on a street corner. That solution-self-reliance-had its complement in consumerism. Can't afford betrothal gifts? Or, unlike your neighbors, can't afford a color TV, a refrigerator, washing machine, or

${ }^{52}$ Liu Zhiqing, "Ziyou guodu—guanyu getihu jingji quan de baogao he sikao" (A Land of Freedom-A Report and Reflections on the getihu Economic Circles). Initially published in Yalujiang zazhi 9: 1988. Reprinted in Wang Lingxu, ed. 1993. Ziyou guodugongshang getihu shenghuo jishi (A Land of Freedom-A Record of the Business getibu Economy). Shanghai: Shanghai Academy of Social Sciences Press. 
even a tape recorder-the new must-have Big-Ticket items? Start a business and with your earnings, compensate for the traditionally and Mao-era low-status associated with commerce by buying high-status items in the form what the Big Three became in the 1980s: a combination of TVs, washing machines, electric fans, and portable cassette players.

It would be easy to describe the foregoing as the natural consequence of the shift from socialism to capitalism in the 1980s. Once upon a time, the state was responsible for everything; then in the 1980s, the market took command. But such a conclusion overlooks the critical role the state played in creating getibu and promoting the positive values associated with them and with the market during the transitions of the 1980s. This state role extended from the national top, particularly in the "reform and opening" policies, to their local implementation in the "smashing of the iron rice bowl" of employment in state-owned enterprises. Neither at the national level nor at the local level did the state "get out of the way" and allow markets to reappear spontaneously. Despite his famous mandate that China "let some to get wealthy first," Deng Xiaoping and the Chinese state did not simply step aside and "let" anyone become wealthy. State policies and their implementation smoothed the path for some to get wealthy first and, in fact, directly or indirectly pushed them to try. ${ }^{53}$

Consumerism was an underlying driver of change. The neighbors of getihu such as Gan Jing envied them not for political reasons-because they were the first to embrace policy changes-but rather for economic reasons. Getibu were the first who could afford nice things, the first to get rich. The perception: the lifestyles of state-owned enterprise employees, the "labor aristocracy" of the Mao era who had benefitted materially the most, had fallen behind getihu competitors. And the gap grew quickly and conspicuously. The Mao era state economy and "socialist" values were not only dismantled on orders from above but also unraveled bit-by-critical-bit from below. The "reform" policies were supported and spread, even in advance of official authorization, because people wanted the latest Big Three. And each new Three Big item begot the desire, even

${ }^{53}$ On the elite political debates over these policies, see Frederick Teiwes and Warren Sun. 2015. Paradoxes of Post-Mao Rural Reform: Initial Steps Toward a New Chinese Countryside, 1976-1981. New York: Routledge; and 2007. The End of the Maoist Era: Chinese Politics During the Twilight of the Cultural Revolution, 1972-1976. Armonk: M. E. Sharpe. 
a need, for a ten more, making any policy reversal increasingly difficult, if not impossible.

CCP policy constructed markets and thereby determined who got rich first, that is, who got to consume what, who could afford the latest Big Three. In the 1980s, the state's role in making some rich first was more subtle, leading scholars to interpret the 1980s as a hopeful decade of mom-and-pop-led entrepreneurial capitalism and freedom in consumerism. These scholars then contrasted the economic freedom of the 1980s with the 1990s, when revived state-owned enterprises (SOEs) became profit-oriented corporations much more directly linked to the state. ${ }^{54}$ The history of consumerism in the PRC teaches that there was no decade of state-free markets and consumerism.

CCP policies effectively promoted consumerism, even during the avowedly anti-consumerist Mao era. Consumerism, therefore, did not arise spontaneously as part of "human nature" with the collapse of the "socialist" experiment after the Mao era. Long before the "reform" era led by Deng Xiaoping, consumerism spread as part of industrialization. Advocates of non-consumerist values will find in this history of the ascendance of consumerism in China a formidable foe. As with other places, consumerism in China has found ways to commercialize everything, even Christmas, which in China was absorbed into one-long consumer shopping period stretching from Single's Day (November 11) through Christmas and up until Chinese New Year a month or so later. ${ }^{55}$ But they may also find opportunity: more consumerism also has witnessed more opposition to the values associated with consumerism in recent decades. There has been both an increase in consumerism and a backlash in the form of attempts to promote other values. The number of Christians, for instance, is skyrocketing. According to the Council on Foreign Relations, China may have the largest number of Christians by 2030, over 240 million believers. The number is growing so quickly that it is predicted to soon surpass the number of members in the CCP itself, some 90 million in

\footnotetext{
${ }^{54}$ Yasheng Huang. 2008. Capitalism with Chinese Characteristics. New York: Cambridge University Press. For a thorough critique, see Joel Andreas. 2010. "A Shanghai Model?" New Left Review 65 (October-November). Another influential study that downplays the role of the state in the economic transformation is Victor Nee and Sonja Opper. 2012. Capitalism from Below: Markets and Institutional Change in China. Cambridge: Harvard University Press.

55 Robert Foyle Hunwick, "Why Christmas Is Huge in China." The Atlantic, 24 December 2014.
} 
$2017 .{ }^{56}$ However, as consumerism is deeply imbedded in all industrialized societies, the ability of non-consumerist values to resist commodification - and defy being turned into consumerist expressions-remains an open question. Even non-consumerist values such as going to church or celebrating Christmas have tended to become part of consumerism. ${ }^{57}$

\section{BIBLIOGRAPHY}

Adas, Michael. Machines as the Measure of Men Science, Technology, and Ideologies of Western Dominance. Ithaca: Cornell University Press, 2015.

Albert, Eleanor. "Christianity in China." Council on Foreign Relations. https:// www.cfr.org/backgrounder/christianity-china, 2018. Accessed 15 August 2018.

Andreas, Joel. “A Shanghai Model?” New Left Review 65 (October-November 2010).

Arnold, David. Everyday Technology: Machines and the Making of India's Modernity. Chicago: The University of Chicago Press, 2013.

Blecher, Marc, and Vivienne Shue. Tethered Deer: Government and Economy in a Chinese County, 63-85. Stanford: Stanford University Press, 1996.

Breen, Timothy H. American Insurgents, American Patriots: The Revolution of the People. New York: Hill and Wang, 2010.

Brewer, John, and Roy Porter, eds. Consumption and the World of Goods. New York: Routledge, 1994.

Bruun, Ole. Business and Bureaucracy in a Chinese City: An Ethnography of Private Business Households in Contemporary China, 48. Berkeley: Institute of East Asian Studies, 1991.

Cao, Nanlai. Constructing China's Jerusalem: Christians, Power, and Place in Contemporary Wenzhou. Stanford: Stanford University Press, 2010.

Cirincione, Joseph. Bomb Scare: The History and Future of Nuclear Weapons, 51. New York: Columbia University Press, 2007.

Clunas, Craig. Superfluous Things: Material Culture and Social Status in Early Modern China. Champaign: University of Illinois Press, 1991.

Cochran, Sherman. Big Business in China: Sino-Foreign Rivalry in the Cigarette Industry, 1890-1930. Cambridge: Harvard University Press, 1980.

56Eleanor Albert. 2018. "Christianity in China." Council on Foreign Relations. https://www.cfr.org/backgrounder/christianity-china. Accessed 15 August 2018.

${ }^{57}$ On the co-optation of Christianity and Christian holidays and rituals, see Nanlai Cao. 2010. Constructing China's Jerusalem: Christians, Power, and Place in Contemporary Wenzhou. Stanford: Stanford University Press. 
Craig, Steve. Out of the Dark: A History of Radio and Rural America. Tuscaloosa: University of Alabama Press, 2009.

Dao, Wen interview of Gan Jing. "Hangzhou diyiwei getihu" (The First getibu in Hangzhou). Hangzhou ribao, 16 March 2016. http://hzdaily.hangzhou.com. $\mathrm{cn} / \mathrm{hzrb} / \mathrm{html} / 2016-03 / 16 /$ content_2217432.htm. Consulted 16 April 2017.

Diamant, Neil Jeffrey. Revolutionizing the Family: Politics, Love, and Divorce in Urban and Rural China, 1949-1968. Berkeley: University of California Press, 2000.

Dikötter, Frank. The Cultural Revolution: A People's History, 1962-1976. New York: Bloomsbury Press, 2017.

Fewsmith, Joseph. Dilemmas of Reform in China: Political Conflict and Economic Debate. Armonk: M. E. Sharpe, 1994.

Frank, Dana. Buy American: The Untold Story of Economic Nationalism. Boston: Beacon Press, 1999.

French, Paul and Matthew Crabbe. Fat China: How Expanding Waistlines Are Changing a Nation. London: Anthem Press, 2010.

Friedman, Edward, Paul G. Pickowicz, and Mark Selden. Revolution, Resistance, and Reform in Village China. New Haven: Yale University Press, 2005.

Gerth, Karl. China Made: Consumer Culture and the Creation of the Nation. Cambridge: Harvard University Press, 2003.

Gerth, Karl. "Lifestyles of the Rich and Infamous: The Creation and Implication of China's New Aristocracy." In special issue of Comparative Sociology 10, no. 4 (2011): 488-507.

Gerth, Karl. As China Goes, So Goes the World: How Chinese Consumers Are Transforming Everything. New York: Farrar, Straus and Giroux, 2013.

Gerth, Karl. "Driven to Change: The Chinese State-Led Development of a Car Culture and Economy." In Energy Transport in Green Transition: Perspectives on Ecomodernity, edited by Atle Middledun and Nina Witoszek. New York: Routledge, 2015.

Glickman, Lawrence B. Buying Power: A History of Consumer Activism in America. Chicago: The University of Chicago Press, 2009.

Gold, T. B. "Urban Private Business and China's Reforms." In Reform and Reaction in Post-Mao China: The Road to Tiananmen, edited by Richard Baum, 84-103. New York: Routledge, 1991.

Goodman, Ruth. How to Be a Victorian: A Dawn-to-Dusk Guide to Victorian Life. London: Viking, 2015.

Grey, Jack. Mao Tse-tung, 46-47. Cambridge: Lutterworth Press, 1973.

Guanren, Chen. "Wenge' you Zhongguo shoujia siying fandian: Yuebin fandian” (Yuebin Restaurant, the First Privately Owned Restaurant in China After the 'Cultural Revolution'), initially published in Zhongwai shu zhai 3 (2005): 3235. www.zwszzz.com/DCFB/bkview.asp?bkid=191395\&cid=630477. 
Harrison, Henrietta. China: Inventing the Nation. New York: Oxford University Press, 2011.

Hart-Landsberg, Martin, and Paul Burkett. China and Socialism: Market Reforms and Class Struggle. New York: Monthly Review Press, 2005.

Hewitt, Brad, and James Moline. Your New Money Mindset: Create a Healthy Relationship with Money. iBook, no pagination, 2015.

Huang, Yasheng. Capitalism with Chinese Characteristics. New York: Cambridge University Press, 2008.

Hunwick, Robert Foyle. "Why Christmas Is Huge in China." The Atlantic, December 24, 2014.

Jhally, Sut. Codes of Advertising: Fetishism and the Political Economy of Meaning in the Consumer Society. New York: St. Martin's Press, 2016.

Jun, Guang. "Hang Liu Zhong zhaokai jiazhang hui" (A Parents' Meeting in Hangzhou No. 6 Middle School). Hangzhou Daily, March 27, 1957.

Lasch, Christopher. Culture of Narcissism: American Life in an Age of Diminishing Expectations. New York: Warner Books, 2018.

Lee, Lily Xiao Hong, ed. Biographical Dictionary of Chinese Women, 198-200. Armonk: M. E. Sharpe, 1998.

Lingxu, Wang, ed. Ziyou guodu: gongshang getihu shenghuo jishi (A Land of Freedom-A Record of the Business getihu Economy). Shanghai: Shanghai Academy of Social Sciences Press, 1993.

McEwen, Susan. "New Kids on the Block." China Business Review 21, no. 3 (May-June 1994): 35-39.

Nan, Wu. "Gaige kaifang hou de xiahai jingshang yanjiu" (A Study of the Trends of Going into Business After the Start of the Reform and Opening Era). M.A. thesis, Liaoning University, 2011.

Naughton, Barry. Growing Out of the Plan: Chinese Economic Reform, 19781993. Cambridge: Cambridge University Press, 1995.

Nee, Victor, and Sonja Opper. Capitalism from Below: Markets and Institutional Change in China. Cambridge: Harvard University Press, 2012.

Perry, Elizabeth, and Li Xun. Proletarian Power: Shanghai in the Cultural Revolution. Boulder: Westview Press, 1997.

Pittaway, Mark. Eastern Europe, 1939-2000. London: Hodder Arnold, 2004.

Qiuhang, Wang. "Yihuang sanshi nian, fangfu jiu zai yanqian" (Everything Still Remembered Vividly After 30 Years). Lao Zhaopian, no. 99 (2015): 73-83. Shandong: Shandong huabao chubanshe.

Reinhardt, Anne. Navigating Semi-Colonialism: Shipping, Sovereignty, and Nation-Building in China, 1860-1937. Cambridge: Harvard University Press, 2018.

Rhoads, Edward J. M. "Cycles of Cathay: A History of the Bicycle in China." Transfers 2, no. 2 (Summer 2012): 95-120. 
Riskin, Carl. China's Political Economy: The Quest for Development Since 1949. Oxford: Oxford University Press, 1987.

Sanchez-Sibony, Oscar. Red Globalization: The Political Economy of the Soviet Cold War from Stalin to Khrushchev, 9. Cambridge: Cambridge University Press, 2014.

Schlesinger, Arthur M. The Colonial Merchants and the American Revolution, 1763-1776. New York: Frederick Ungar, 1957 [1918].

Schoenhals, Michael. Doing Things with Words in Chinese Politics: Five Studies. Berkeley: Center for Chinese Studies, Institute of East Asian Studies, University of California, 1992.

Solinger, Dorothy J. "Commerce: The Petty Private Sector and the Three Lines on the Early 1980s." In Three Visions of Chinese Socialism, edited by Dorothy J. Solinger, 73-111. Boulder: Westview Press, 1984.

Swett, Pamela E., S. Jonathan Wiesen, and Jonathan R. Zatlin, eds. Selling Modernity: Advertising in Twentieth-Century Germany. Durham: Duke University Press, 2007.

Teiwes, Frederick, and Warren Sun. Paradoxes of Post-Mao Rural Reform: Initial Steps Toward a New Chinese Countryside, 1976-1981. New York: Routledge, 2015.

Teiwes, Frederick, and Warren Sun. The End of the Maoist Era: Chinese Politics During the Twilight of the Cultural Revolution, 1972-1976. Armonk: M. E. Sharpe, 2007.

Thompson, E. P. “Time, Work-Discipline, and Industrial Capitalism.” Past \& Present 38 (1967): 56-97.

Trentmann, Frank. Empire of Things: How We Became a World of Consumers, from the Fifteenth Century to the Twenty-First. London: Penguin Books, 2017.

Tungate, Mark. Adland: A Global History of Advertising, Ed. 2. Philadelphia: Kogan Page, 2013.

Unger, Jonathan. The Transformation of Rural China. Armonk, NY: M.E. Sharpe, 2002.

Walder, Andrew. China Under Mao: A Revolution Derailed, 331. Cambridge: Harvard University Press, 2015.

Young, Susan. Private Business and Economic Reform in China, 6. New York: Routledge, 1995.

Yu, Miin-ling. "Labor Is Glorious"”: Model Laborers in the People's Republic of China." In China Learns from the Soviet Union, 1949-Present, edited by Thomas P. Bernstein and Hua-Yu Li. Lanham: Lexington Books, 2010.

Yuanhang, Ren. "Qian yao yong zai daokou shang” (Money Ought to Be Spent on the Blade). Hangzhou Daily, August 22, 1957.

Yuanhang, Ren. "Shucai diqi bufen nongmin zizhang langfei xianxiang" (The Phenomenon of Vegetable Farmers Overspending). Hangzhou Daily, July 25, 1957. 
Yudkin, Marcia. Making Good: Private Business in Socialist China, 30. Beijing: Foreign Languages Press, 1986.

Zeng, Xiaowei. "Market Transition, Wealth and Status Claims." In The New Rich in China: Future Rulers, Present Lives, edited by David S. G. Goodman, 5370. London: Routledge, 2008.

Zhanliang, Zhu. "Shanghai qinggongye mingpai chanpin chutan" (A Brief Analysis of Famous Brands Produced by Shanghai Light Industry). Shanghai jingji yanjiu 9, no. 9 (1981): 7-11.

Zhou, Kate Xiao. How the Farmers Changed China: Power of the People. Boulder: Westview Press, 1996.

Open Access This chapter is licensed under the terms of the Creative Commons Attribution 4.0 International License (http://creativecommons.org/licenses/ by $/ 4.0 /$ ), which permits use, sharing, adaptation, distribution and reproduction in any medium or format, as long as you give appropriate credit to the original author(s) and the source, provide a link to the Creative Commons license and indicate if changes were made.

The images or other third party material in this chapter are included in the chapter's Creative Commons license, unless indicated otherwise in a credit line to the material. If material is not included in the chapter's Creative Commons license and your intended use is not permitted by statutory regulation or exceeds the permitted use, you will need to obtain permission directly from the copyright holder.

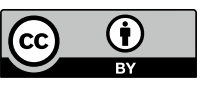




\title{
Anglican Christians and Modern Political Economy
}

\author{
Salim Rashid
}

Faith is belief in things unseen, while Finance is the bringing of savers and investors together. Since both saving and investing requires some beliefs about the future, there is an obvious sense in which Finance implies faith about law, property, society, and so on. But this connection lacks depth or consequences and seems almost trivial. The more common connotation of faith involves the holding of distant views which motivate lifelong activity-while stocks and bonds can be instruments in such a life, finance must have a larger vision to accompany such faith. Ending poverty implies the diffusion of plenty among a people and economic growth is essential for the spread of plenty. ${ }^{l}$ Growth requires investment, which in turn is possible with saving. Since the meeting of savers and investors defines finance, a more promising approach is to ask how faith has contributed

${ }^{1}$ As opposed to a simple redistribution of existing wealth, always the Easiest way of achieving equality of possessions.

\author{
S. Rashid ( $\bowtie)$ \\ Emeritus Professor, Department of Economics, University of Illinois-Urbana \\ Champaign, Urbana, IL, USA \\ e-mail: srashid@illinois.edu \\ University Professor, East West University, Dhaka, Bangladesh \\ (C) The Author(s) 2020 \\ T. Akram and S. Rashid (eds.), Faith, Finance, and Economy, \\ https://doi.org/10.1007/978-3-030-38784-6_6
}


to those forms of finance which enable growth with equity-to that economic growth which diffuses plenty.

That Christianity is the backbone of European economic growth has long been a thesis of mine. ${ }^{2}$ Since economies function well only when ensconced within supportive societies, any hypotheses about the influence of religion on society, and vice versa, has to relate the economy to society independently of religion. What societal beliefs are central to a well-functioning market economy? There are five forms of faith that are essential for markets to flourish. As a mnemonic, they are called 'ethics' below:

1. Legal ethic or the rule of law

2. Consumption ethic or the fitness of commodities

3 . Work ethic or the rightness of effort

4. Knowledge ethic or the glory of knowing

5. Support ethic or the unconditionality of social bonds.

Showing how and why Christianity was an essential part, sometimes a driving force, in each 'ethic' between 1000 and 1800 requires lengthy arguments. Social change typically involves multiple proximate causes. Tracing each such cause back to its Christian impetus, even when possible, involves long, complex arguments. Furthermore, since Christians themselves freely acknowledged their debts to the Hellenes and the Romans, separating the roots is almost impossible. ${ }^{3}$ Some of the proofs are easy, as in showing the widespread prevalence of the support ethic, encouraged and institutionalized by Christianity, through the ages. Evidence for some others, such as the rule of law, become manageable once we look for the right evidence-not necessarily in the lawbooks, but in the lives

${ }^{2}$ That Christianity has been an essential pillar of Western civilization has been argued by many, as my references to Herbert Butterfield and Christopher Dawson will illustrate. The topic has been argued more recently by such authors as Rodney Stark. Supporting this general proposition through specifically economic arguments appears to be new. The focus upon Markets and Christian theology by authors, such as Geoffrey Brennan and A. M. C. Waterman, is entirely different. David Rose's highly acclaimed book on The Moral Foundation of Economic Behavior (Oxford 2011) has only a single reference to Christianity.

${ }^{3}$ Fénelon Archbishop of Cambray, chose to describe the Hellenes for their instructive value. Lives of the Ancient Philosophers (New York, 1900). 
of the ordinary people. ${ }^{4}$ For the curious reader, especially in an age when we are intermittently gripped by Luxury Fever, ${ }^{5}$ it may be interesting to note that the hardest ethic to accept in a Christian society has been that legitimizing consumption.

I have chosen here a simpler path. Are there questions where the issue can be decided by arithmetic? Intellectual priorities for several modern ideas can be determined by dates and by the public impact. If Anglican Christians have the priority in several such instances, then perhaps the rest of the case is not hopeless. I will make the case below using the topic of economic growth, and the impediments to the spread of such growth from Europe to the rest of the world.

Why are the Anglicans particularly important for my thesis? First, because Britain led the world into the Industrial Revolution, a point that needs no elaboration. Secondly, because the Anglican clergy were generally well educated, with the clerical hierarchy containing many intellectuals notable in their own right. Such education provides the ability to respond to social change; more importantly, the clergy believed in Christianity as intellectually equal to facing any intellectual challenge, which led David Hume to once refer to Christianity as a 'philosophical superstition. ${ }^{6}$ Hence the Anglican clergy repeatedly entered the fray, especially where the well-being of their flock was concerned. The period I will cover is the eighteenth century, which has become popularized as the 'Enlightenment.' One feature of the Enlightenment was its claim that people should forget about the afterlife and concentrate on being happy here on earth. But how? If worldly wealth made people happier, then, as I will show, it was the clergy who were most active in promoting the wealth of the poor.

A further reason for focusing upon Britain is that there are plenty of primary materials - in English, the only language I read with some ease. It is very important to realize, and practically impossible to appreciate, just how crucial primary materials are for such historical study. When we approach the lives of those who lived in earlier times, the primary goal

\footnotetext{
${ }^{4}$ My colleague, Edward McPhail, and I are working on a paper called 'Golden Rule vs Greatest Happiness', a title inspired by Lord Macaulay's review of Jeremy Bentham's utilitarian prescriptions, where Macaulay stated that Britain did not need the Greatest Happiness principle because it already possessed the Golden Rule from Christianity.

${ }^{5}$ The title of a relevant and readable book by Robert Frank (Free Press, 1999).

${ }^{6}$ And especially pernicious therefore.
} 
must not be to praise or blame, but to understand. Only after we have tried to see the world through 'their' eyes, should we try to evaluate. Such understanding can only be obtained by trying to see the world as the people we are studying saw the world. Primary sources allow us to enter the minds of those we read.

'Knowledge,' in the abstract, does not exist. Just as cultures fade away unless they are remembered and exercised, so too knowledge withers away. Knowledge has to be recognized, filtered, preserved, transmitted, reframed, and retransmitted. All these acts need resources-who will commit the time, energy and money? So if something is now 'common knowledge,' we have also to ask-in whose interest did this knowledge arise and awaken? For almost fifty years I have been astonished at the limited understanding in the West of the Christianity I will speak of. Primary sources are the most, perhaps the only, authoritative source for 'disputed' issues; they are also the only way to uncover 'buried' issues e.g. how would one know by reading the webpage of the European Union that the most active founders of the EU were inspired by their own liberal Catholicism? ${ }^{7}$

${ }^{7}$ Due to space limitations, I have had to choose between giving references for my general thesis or for my specific illustrations. Since my own papers have covered the specific issues in more detail, I have chosen to give references mostly for the general thesis about Christianity. This is unfair to many scholars and I apologize in advance. The references are as follows. Rashid, Salim, "Richard Whately and Christian Political Economy at Oxford and Dublin," Journal of the History of Ideas, Vol. I (1977), 144-155. Rashid, Salim, "Richard Whately and the Struggle for Rational Christianity in the Mid Nineteenth Century," Historical Magazine of the Protestant Episcopal Church, Vol. 47 (September 1978), 293-311. Rashid, Salim, "Richard Jones and Baconian Historicism at Cambridge," Journal of Economic Issues, Vol. 8 (March 1979), 159-176. Rashid, Salim, "Anglican Clergymen-Economists and the Tithe Question in the Mid Nineteenth Century," Journal of Religious History, Vol. 11 (Fall 1980), 64-76. Rashid, Salim, "He Startled as If He Saw a Spectre: Josiah Tucker's Proposal for American Independence," Journal of the History of Ideas, Vol. 43 (July 1982), 439-460. Rashid, Salim, "Josiah Tucker, Anglican AntiSemitism, and the Jew Bill of 1753," Historical Magazine of the Protestant Episcopal Church, Vol. 51 (June 1982), 191-201. Rashid, Salim, "Christianity and the Growth of Liberal Economics," Journal of Religious History, Vol. 12 (1982), 221-232. Rashid, Salim, "The Clergymen-Scholars of Economic Development," This World, no. 5 (Spring 1983), 94-106. Rashid, Salim, "The Irish School of Economic Development: 1720-1750," The Manchester School of Social and Economic Studies, Vol. LVI, no. 4 (December 1988), 345-369. Rashid, Salim, "Berkeley's Querist and Its Influence," Journal of the History of Economic Thought, Vol. 12 (Spring 1990), 38-60. Rashid, Salim, "Christianity and Economics: Is There A Lacuna?" Anglican and Episcopal History, Vol. LX, no. 1 (March 1991), 25-42. Rashid, Salim, "Jonathan Swift, Wood's Halfpence and Anglican Passive resistance," unpublished. 


\section{Three Remarkable Men: Berkeley, Swift, ANd Tucker}

I will present the most salient aspects of the economic thoughts of three eighteenth-century Anglican clergymen, George Berkeley, Jonathan Swift, and Josiah Tucker. While Berkeley is well-known as a philosopher, and Swift is even more famous as the author of Gulliver Travels, Tucker is practically forgotten today, even though in his times he was probably more in the news than either of the other two. Berkeley provided a complete and convincing theory of economic development, framed with Ireland in mind. Swift considered English rule of Ireland to be oppressive and argued for passive resistance as the only path open in the face of overwhelming force; he rebelled at the thought that Ireland was being sold out to the English and saw the need for 'nationalism' in the Irish to further their development. Tucker was convinced that War for the sake of Trade was unchristian, and spent some thirty years showing why rich countries need not fear the growing riches of poor ones, so they should not consider force as a solution for any international economic problems.

Two of the three clergymen, Berkeley and Swift, were Anglo-Irish, and with good reason. Ireland was the first 'colony' of Europe, so it was natural that their experience would adumbrate later events. Ireland was originally annexed to England by conquest and its subordination to London was reinforced by the wars of the 1690s. An army of around 12,000 regular soldiers kept the peace, which was administered by the appointment of Englishmen to high political and ecclesiastical office, and the control of Irish legislative decisions through Poynings's Law of 1495 (not repealed until 1782) and the Declaratory Act of 1720. Anglo-Irish formed the top of the Irish pyramid, followed by Scot Presbyterians and the native Irish Catholics (and the dissenters) were constrained by Penal Laws. England regarded Ireland as a colony. What is notable is that the revolt against the English was led by members of the Anglo-Irish elite. William King, Archbishop of Dublin and the most determined proponent of the Irish 'nation,' expressed the Irish position best ${ }^{8}$ : 'Our payments are like the fleecing of sheep, of which they have no benefit, but must prepare a new growth out of their bodies or remain naked'.

George Berkeley is known today as the Philosopher of immaterialism and as a Christian apologist. Even at a young age, his idealism struck

${ }^{8}$ King to Addison, August 25, 1715. 
those whom he met. It was this idealism that led him to project a College in the Bermudas, which would serve for the Christian regeneration of the New World. He left for Rhode Island with the hope of creating a purer society in the New World. The funds he was promised to start his venture never came, so he returned to Britain and was exiled to Cloyne, perhaps the poorest diocese in Ireland. Dedicating himself to the poor upon reaching Cloyne, Berkeley wrote the most philosophical treatise on economic development yet written-the Querist. The style is strange, in that the entire pamphlet consists of queries, appropriate words from one who is the Querist, until one realizes that every question posed is rhetorical and carries its own answer. To those who asked why a clergyman would write on economics, Berkeley said, in the introduction to the second edition of the Querist 'To feed the hungry, and clothe the naked, by promoting an honest industry, will perhaps be deemed no improper employment for a clergyman who still thinks of himself a member of the commonwealth.' Berkeley was praised by many contemporaries-by the Scots Robert Wallace, Lord Lauderdale, Dugald Stewart, and the English poets Robert Southey and Samuel Taylor Coleridge. Alexander Pope said of him, 'To Berkeley, every virtue under heaven.'

Jonathan Swift took holy orders in 1695 and soon thereafter came to the attention of the Archbishop of Dublin, William King, mentioned earlier. King sent Swift to London to canvass for the First Fruits, which would augment the income of the Irish Anglican church. Swift's literary abilities made him many friends in London and he soon came under the eye of the Tory politicians and used his pen to serve Tory purposes. With the fall of the Tories and the change of monarch from Queen Anne to King George I, Swift rapidly fell from grace and went back into 'exile' in Ireland. King again cultivated Swift and when the English sliced off the independence of the Irish Parliament, the two began to think of systematic opposition. Swift began, in 1720, with a pamphlet which carried the memorable message, 'Burn everything English, except their people and their coals.' When the English tried, in 1722 , to introduce a new halfpenny coin by giving the monopoly of it's production and distribution to William Wood, an Englishman, Irish anger boiled over. A boycott of the new coin was successfully organized-quite remarkable in view of the fact that much money within Ireland was circulated by the army, and refusing their expenses could grind everyday activity to a halt. Passive resistance, a form of civil disobedience, had been pioneered earlier by Archbishop Sancroft and the non-jurors; Swift extended it into ordinary politics. What 
Swift hoped to do was to galvanize the Irish elite into standing united as 'nationalists' against the English.

Josiah Tucker began his clerical career as chaplain to Bishop Joseph Butler, then analyzed the strengths and weaknesses of the English and French comparative economies 1750, Even at this early stage he appreciated immigrants.

What! must Foreigners, and we know not who, come and take the Bread out of our Mouths?... Let us see therefore in the next Place, Out of whose Mouths' do they take this Bread? If they introduce new Manufactures, or carry those already established, to greater Perfection, in that Case the Publick' is greatly benefited, and no Individual can be injured. ${ }^{9}$

It is no surprise that Tucker next wrote as a supporter of the Naturalisation of Foreign Protestants in 1753, then of the Naturalisation of Jews in 1754. The liberal bent of the Anglican hierarchy can be seen from the fact that Tucker was appointed tutor to the Prince of Wales in 1756. The Seven Years War turned him against all wars for the sake of trade and led to a pamphlet, The case of Going to War for the sake of Trade in 1763. In 1767, he suggested that the Americans were planning independence while protesting loyalty. Tucker's solution was to set the Americans free. He vigorously opposed war against the Americans; while Tucker's arguments gained an appreciation, they were unpopular, so Tucker began calling himself 'Cassandra' because of the derision and neglect he aroused. Tucker's formulation of the role of self-interest has rarely been bettered and was approvingly quoted by libertarians. Tucker unhesitatingly ascribes secular happiness to self-love and then asks what role reason has to play. ${ }^{10}$

Not surely to extinguish self-love; that is impossible. And it might be questioned whether it would be right to attempt even to diminish it. For all arts and sciences, and the very being of arts and commerce, depend upon the right exertion of this vigorous and active principle... Consequently, the main point to be aimed at, is neither to extinguish nor enfeeble self-love, but to give it a direction, that it may promote the public interest by pursuing its own. And then the spirit of monopoly will operate for the good of

${ }^{9}$ A Brief Essay on the Advantages and Disadvantages which Respectively Attend France and Great Britain, with Regard to Trade: With Some Proposals for Removing the Principal Disadvantages of Great Britain. In a New Method. Josiah Tucker T. Trye (1750), p. 85.

${ }^{10}$ Shelton (1981), pp. 91-92. 
the whole.....and if this is the proper business of reason. Divert therefore the pursuits of self-love from vicious or improper objects, to those that are commendable and virtuous.

\section{GeOrge Berkeley}

Berkeley was but one of many who tried to comment and prescribe for Ireland between 1680 and 1740. Although space will only permit consideration of Berkeley and Swift, those who elaborated upon the ideas stated below all took Christianity seriously, hence their relevance to this paper. Berkeley made two fundamental contributions. First, he provided the first definition of development that explicitly included all the people:

- 'Whether a people can be called poor, where the common sort are well fed, clothed and lodged?'

- 'Suppose the bulk of our inhabitants had shoes to their feet, clothes to their backs, and beef in their bellies, might not such a state be eligible for the public, even though the squires were condemned to drink ale and cider?'

Note how equity is written into the definition of development by Berkeley. This is also the major change in view that took place after WWII.

Berkeley's second major contribution lay in clarifying how wealth arises, a crucially important task in an age when many were distracted by the acquisition of gold and silver.

- 'Whether the four elements, and man's labour therein, be not the true source of wealth?'

This was clarity, not originality. By the time Berkeley came to revise the Querist in 1743, he clearly noted that it is human capital that is the real fount of growth.

- 'Whether faculties are not enlarged and improved by exercise?'

- 'Whether the sum of the faculties put into act, or in other words, the united action of a whole people doth not constitute the momentum of a State?'

- 'Whether such momentum be not the real stock of a State?' 
- 'Whether in every wise State the faculties of the mind are not most considered?'

- 'Whether the momentum of a State doth not imply the whole exertion of its faculties, intellectual and corporeal; and whether the latter without the former could act in concert?'

I cannot over-emphasize how important Berkeley's contribution is. The most important economic fact post WWII is that demonstrated by the East Asian economies-7\% per capita growth is achievable. It is a growth rate that doubles income every 10 years so if one starts with 10,000 at age 20 , one retires with 160,000 at age 60 . It means the end of poverty in one lifetime. The factor that has contributed most to such growth and forced its attention upon the profession is human capital. So Berkeley is twiceblessed; in defining development and in focusing upon its most important cause. $^{11}$

As this paper is dealing only with concepts like wealth, growth and the distribution of wealth-what economists like to call 'real' variables, to distinguish them from 'monetary' ones like money supply and pricesit is well to remember that both Berkeley and Swift made notable contributions to money and finance. Swift began the Irish loan fund with the first 500 pounds he saved. This was then loaned out to those who could provide a character reference. Swift provided what has come to be known as micro-credit, with the condition that one needed a reference who provided a 'character collateral' instead of a peer group which accepted responsibility for the loan and provided an alternative monitoring mechanism for the loan. While the rich must always have given 'collateral free' loans to the poor, Swift's Loan Fund is the earliest institution to provide micro-credit. Berkeley urged upon his contemporaries the view that money was only a ticket, a counter, which was useful in creating and circulating real wealth. While this was a minority view at that time, Berkeley's pithy presentation gave it much clarity and force. Berkeley insisted

${ }^{11}$ To be fair to the Irish school, a few words on the general program. What can be done within the market? The wealthy must encourage and appreciate Irish products; housing, painting, etc. The poor must acquire a taste for riches, this will elevate their standards and make them willing to work hard. Absentees who stayed abroad but lived off Irish revenues should learn to accept their responsibilities in Ireland. When government will not help, form a voluntary society to propagate your goals-the Dublin Society; in modern parlance, the first NGO. 
that the primary policy tool was a proper monetization of the economy. While many others had seen the utility of a bank, it was Berkeley who wanted to create one which functioned for the benefit of the public, and not for private profit alone. He left his bishopric at Cloyne and spent a year in Dublin to try and convince the Irish Parliament to authorize a national Bank, complete with instructions for a constitution. Failure seems to have embittered Berkeley and he never again tried to initiate policy changes so directly; he even removed all the queries relating to the bank in a revised edition of the Querist. Berkeley not only espoused a national bank, but he also had the prescience to see that a National Debt can serve to stabilize the entire monetary system.

- Whether the credit of the public funds be not a mine of gold to England?

- And whether any step that should lessen this credit ought not to be dreaded?

- Whether such credit be not the principal advantage which England hath over France? I may add, over every other country in Europe.

- Since the monetization of the National Debt was perhaps Britain's most significant financial innovation in this century, Berkeley deserves more credit for his insight.

\section{JoNATHAN SWIFT}

The agitation that marked the 1720s in Ireland began when the patent to coin halfpence was granted to an Englishman, William Wood. The Irish felt this was a ruinous change and united against the measure. Such unity took the English administration quite by surprise. The unity was largely forged by the prose of Jonathan Swift, who posed as a Drapier and wrote the famous Drapier's Letters, to arouse and unite Irish opposition. The plan was to unite in refusing to accept the new coin-seemingly impossible, but it succeeded, and Swift hereafter forever linked with the cause of liberty for Ireland. The Drapier's Letters make for poor economics, and Swift's genius lay in writing in popular language and using such arguments as would arouse Irish enthusiasm for the boycott. In the midst of the debates, Swift wrote a self-conscious sermon about passive resistance 
which needs appreciation. He was almost certainly influenced by Archbishop Sancroft, who had earlier grappled with the question 'How does one respond to overwhelming force?'

Sancroft's life and career were full of contrary events. As a royalist, Sancroft believed kings were appointed by God, so the beheading of Charles I meant that he had to transfer his loyalty to Charles II. So he lived in exile, so to speak. Upon the Restoration of Charles II, Sancroft was rewarded with desirable church appointments and rapid promotions, leading from the Deanery of St Paul's in 1664 to the Archbishopric of Canterbury in 1677. When Charles died, James II was crowned by Sancroft himself. As James II began his policy of favoring Catholics, Sancroft found himself torn between his loyalty to his King and his loyalty to the Anglican church. When proclamation of the Declaration of Indulgence was required by James in 1687, Sancroft and six other bishops petitioned the King. This was viewed as an act of rebellion and James imprisoned the seven bishops. Exercising the right to petition was a form of democratic disobedience. Despite the imprisonment, five of the seven bishops remained loyal to James even after James fled upon the arrival of William and Mary. Sancroft, eight other bishops, and 400 members of the clergy, refused to take the oath of allegiance to William and Mary and were known as the non-jurors. They were all fired from their posts and largely slipped into out of the history books. Faced with a choice between their conscience and their positions, the non-jurors sacrificed all worldly ambition. Not a few or a dozen or even a hundred but four hundred did so. The Anglican church pioneered passive resistance in the petition to James, loyalty in the face of imprisonment and the refusal to take the oath of loyalty to William and Mary.

The sermon, 'Doing Good,' was delivered in 1724 , at a time when Swift was working very hard and taking a considerable risk to keeping Irish resolve united in rejecting the new coinage of Wood. ${ }^{12}$ How could the Irish obtain a complete repeal of Wood' halfpence? The sermon provides a map of the intellectual challenges in organizing movements of passive resistance. Swift begins by noting the pervasive power of self-interest, but does not consider it to be ill; rather, and surprisingly, Swift takes selfinterest to be a directive of the Creator. 'The law of nature, which is the

${ }^{12}$ Swift, Jonathan, 'Doing Good,' in Herbert Davis (ed.), The Prose Works of Jonathan Swift, Vol. 9 (Basil Blackwell, Oxford, 1955 [1724]), pp. 232-240. As the sermon is short, I have avoided page references for readability. 
law of God, obligeth me to take care of myself first.' This self-love is commonly meant to extend to one's neighbors, as is well-known. Swift has to motivate hundreds of thousands, not to avoid the market, or even be selective in what to trade or consume, or wear, but only to refuse Wood's Halfpence as payment for any trade-all other coin was fine. So he develops the theme that undergirds his subsequent argument-small sacrifices by me which enable great gains for my neighbor become duties incumbent upon me. 'But if, by a small hurt and loss to myself, I can procure a great good to my neighbor, in that case his interest is to be preferred.'

Swift has rehearsed a well-known point about loving our neighbor, but immediately extends it to a political context by referring to 'our neighbor in a public capacity' which is but another way of referring to one's fellow citizens.

there is yet a duty of a more large extensive nature incumbent on us; which is, our love to our neighbour in his pubic capacity, as he is a member of that great body the commonwealth, under the same government with ourselves; and this is usually called love of the public, and is a duty to which we are more strictly obliged than even that of loving ourselves; because therein ourselves are also contained, as well as our neighbors, in one great body. (p. 233)

Swift continues with the point that it was this love of the public that was termed 'virtue' by Hellenes and Romans.

Swift then lists three reasons why this duty to the public is so strongly binding, before going on to elaborate why they are important and how individuals can display such virtue.

First, that there are few people so weak or mean, who have it not sometimes in their power to be useful to the public....

Secondary, That it is often in the power of the meanest among mankind to do mischief to the public.

And, lastly, that all willful injuries done to the public are very great and aggravated sins in the sight of God. (pp. 113-114)

It is the second point that requires close attention because Swift has to persuade thousands of poor shopkeepers and peasants that they must continue to refuse the new coin-none of them must feel that their individual actions are too insignificant to matter, hence to follow their own convenience and accept the coin. Swift insists that even the meanest can do 
mischief, and then notes the importance of such actions as the principal source of public misfortune. 'it is often in the power of the meanest among mankind to do mischief to the public. And hence arise most of those miseries with which the states and kingdoms of The earth are infested.' (p. 116). Swift gives a recent economic example from the cloth trade, where the bad wares of some had hurt the trade of all, to bring home the force of such behavior '... we now find by experience, that the meanest instrument may, by the concurrence of accidents, have it in his power to bring a whole kingdom to the very brink of destruction' Swift jumps from the cloth trade to coin without any warning and claims that the same selfishness is still 'endeavouring to finish his work; and hath agents among ourselves, who are contented to see their own country undone, to be small sharers in that iniquitous gain, which at last must end in their own ruin as well as our.'

In the analytical language of economics, Swift was dealing with a public goods issue. ${ }^{13}$ Everyone would gain from a good currency, but no one individual would have an incentive to maintain the monetary system since his own gain or loss was infinitesimal compared to the aggregate.

Every man is upon his own guard for his private advantage; but, where the public is concerned, he is apt to be negligent, considering himself only as one among two or three millions, among whom the loss is equally shared, and thus, he thinks, he can be no great sufferer.

This prescient statement was followed by the recognition that material self-interest alone was inadequate to prevent an ill outcome; what was needed was a sense of concern for the public, thus harking back to the principle that he had established earlier-enduring a small harm becomes a duty if great good can be thereby attained.

Against which there can be no defence, but a firm resolution in all honest men, to be closely united and active in shewing their love to their country, by preferring the public interest to their present private advantage.

13 The public goods argument of Swift is also highlighted in McPhail-Rashid (2012). McPhail, Edward, and Salim Rashid, "Swift and Berkeley on Economic Development," in T. Boylan, R. Prendergast and J. Turner (eds.), A History of Irish Economic Thought (Routledge, London, 2010), pp. 32-55. 
There are two ordinary acts which can prove to be very harmful-the spreading of rumors and making false accusations. Swift singles these out for attention, since either can cause the will of the people to falter, and warns his hearers not to indulge in either. There is no evidence that the sermon itself was effective in arousing further opposition to Wood's Halfpence. ${ }^{14}$ That was the function of the Drapier's Letters. Rather, the sermon tells us how Swift thought about this unusual obligation and how he rationalized his activity with his role as pastor. Swift was greatly moved by Sancroft and when the English tried to force Wood's halfpence on the Irish, he willingly put his talents to work in arousing public noncooperation.

To Swift, this was the beginning of a more persistent rejection by the elite of the plums given by the English to keep Irish separatist tendencies in check. Why does this matter? Because simple accumulation in a poor country normally leads to the flight of the rich. As all the good things of life are more available in rich countries, even more so the opportunities for the talented, those who are rich or talented in a poor country will be tempted to leave home and migrate. However, understandable such mobility of brains and capital may be, it necessarily drains the poor country. Something must hold you to your country. This something cannot be material comfort, because, by assumption, you are a poor country. A simple way to describe this immaterial glue which keeps talent at home is 'Nationalism.' Developing countries have produced many heroic figures who could have easily made much money by migrating-Lee Kuan Yew of Singapore is a recent example-yet chose to stay at home because they believed in developing 'their' country. ${ }^{15}$ The flight of talent is perhaps the single greatest problem facing economic development today. Swift understood the problem and tried to mold Irish Nationalism with his writings.

${ }^{14}$ The awareness that in using the pulpit, Swift risked arrest and trial, comes out in one of his last sentences. 'And this, I am sure, sure, cannot be called meddling in affairs of state.' How Swift could claim that, after months of public struggle between the Westminster, the Lord Lieutenant and the Irish Parliament, the question of Wood's halfpence 'cannot be called meddling in affairs of state' must be left one's imagination. It was fortunate for Swift that the sermon was not widely noticed.

${ }^{15}$ Per contra, those poor countries whose leaders have concentrated on building their bank balances, despite the immense resources the poor countries possess, have stagnated in poverty. 


\section{JOSIAH TUCKER}

Josiah Tucker was born in 1713, graduated from Oxford, and took holy orders in 1736. In 1737 Bishop Joseph Butler urged Tucker to write a critique of Methodism, which may have led to Tucker's promotion to the rectorship of St Stephen's, Bristol, in 1749. Tucker wrote next to a widely read pamphlet comparing and contrasting the British and French economies. In subsequent years he argued vigorously for the value of immigrants and defended foreign protestants and then Jews. These writings led Bishop Hayter of Norwich to ask Tucker to compose a book on Commerce for the edification of the Prince of Wales, the future George III. This just as the Seven Years War began. Tucker's liberal and pacific ideas found no home. The stupendous victories of Britain in the Seven Years War led Tucker to venture with a pamphlet asking whether there could be a case for going to war for the sake of trade. Bitter about the public adulation for the victorious Pitt the Elder, Tucker exclaimed: 'Heroism is the wish and envy of all Mankind...let a Prince but feed his subjects with the empty diet of military fame, it matters not what he does besides...' The basis of Tucker's objection was that a benevolent God would not have created a world where mutual prosperity was incompatible with peace.

- 'Do the inhabitants of two adjoining towns or counties believe that they have an unalterable enemity with each other? Or do they believe that the Government they live under can ensure that the good of one is also the benefit of the other?'

- 'If therefore this is the case with respect to human Governments ...how then comes it to pass, that we should ascribe so much Imperfection, such Want of Benevolence, such Partiality, nay such premeditated Mischief to that great and equal Government, which presideth over all?’

The choice of the question and the nature of the solution were provided to Tucker by his faith-what then remained? To demonstrate the correctness of the conclusion through argument. Tucker got his chance when he pleaded that the American colonies should be left to go free-every colony had aspired to independence as soon as it was able to do so, it was only the Americans who protested loyalty even as they took steps to ensure independence. Do the Christian thing and, 'Let them go,' Tucker 
urged, so that we can become friends and Christians again. The political arguments do not concern us here, but the economic ones are worth noting, as they exemplify what it means to analyze a question of fact, what economists call 'positive' ones, while approaching the issue with faith, or what economists call a 'normative' approach.

In 1774 Tucker published Four Tracts, perhaps the best-selling of all his writings. He begins This is most evident in a later pamphlet developing the same theme, when Tucker argues that rich nations need never be overtaken by poor ones, provided they preserve their industry, ingenuity, and activity.

1. They have the advantage in institutions and infrastructure

2. They have the means and the capacity for inventing more

3 . They have the means to direct research more productively

4. Higher wages induce more exertion and invention

5. Riches permits a finer, more productive division of labor

6. The products of the rich, sold competitively, are cheaper and better

7. Capital is cheaper and more productive in a rich country.

Whether you agree or disagree, these are clear arguments. Bernard Semmel has demonstrated how they were influential in Parliamentary debates on Ireland in the 1770s. ${ }^{16}$ Tucker does not rest on general propositions. In Tracts 2 and 3, Tucker lays out his proposal for separation and its benefits. He applies his ideas to the American colonies, since it was widely feared that the loss of the colonies would be ruinous to British commerce. Tucker argued that since 'trade is not carried on for the sake of friendship, but of interest,' it only remained to ask where the interest of the colonists would lie after independence. Commodity after commodity is examined, and Tucker carefully points out how Britain would remain the best market for the colonists. Pitch, Tar and Naval stores, then Pipestaves and Lumber, then Rice and Tobacco and so on. The beginning of Tucker's reply to the Rice and Tobacco will sufficiently illustrate his method.

\footnotetext{
${ }^{16}$ Semmel, Bernard, The Rise of Free-Trade Imperialism (Cambridge University Press, Cambridge, 1970).
} 
[Objection] In case of a Separation, from whence shall we procure Rice and Tobacco? Answer 1: This objection turns on two suppositions, viz l. That after a Separation, the Virginians and Carolinians will not sell Tobacco and Rice to English merchants, for a good price, and ready money; and 2dly, that Tobacco and Rice can grow in no part of the Globe, but in Virginia and Carolina. Will any man in his senses affirm either of these things?

So independent was Tucker that he irritated both Court and Opposition. But he did not care. Just a fifth tract was in the press, Tucker heard about the defeat of Cornwallis, and placed a postscript: 'I am at a loss what to say on this occasion. To congratulate my country on being defeated is contrary to that decency which is due to the public. And yet, if this defeat should terminate in a total separation from America, it would be one of the happiest events that has ever happened to Great Britain.'

Tucker was read by many influential scholars and politicians. Bernard Semmel has shown how the ideas of Tract 1 were to be the foundation of what has been called 'Free Trade Imperialism'-the use of free trade for colonizing ends, an end that was never Tucker's aim! Dr. Samuel Johnson said of Tucker that 'No person, however, learned, can read his writings without improvement'; while John Wesley was led to reverse his initial stand against the Americans and for war. In June 1775, he had supported subduing the colonies but by December he wrote 'But I say as Dean Tucker, "Let them drop."”

\section{Conclusion-What Price Ignorance?}

Berkeley, Swift and Tucker covered some of the principal issues facing both developed and developing countries. But this by no means indicates the overall impact of Christian social thought. Richard Whately was the most effective popularizer of free markets in the nineteenth century; if we turn to policy, Bishop Fleetwood on Index Numbers and Henry Thornton on Banking come readily to mind; on the wider field of social economics, the Rev. Richard Jones is a major nineteenth-century figure. Churchmen were active in all forms of social reform such as the reform of prisons (Howard), the relief of debtors (Oglethorpe and Hanway) or slavery (Wilberforce). The critical role of Anglicanism persists in importance even as we cast a wider net. From the time when the judicious Hooker pleaded for a religion that possessed both richness and structure, to the efforts of many Christians to further science and innovation, to the 
philosophical acumen of Cudworth, Clarke, and King, there is a continuous chain of Anglican engagement on all issues concerning society. One cannot begin to penetrate the life of England without facing Anglicanism.

If Christians have been continuously engaged with the financial and monetary aspects of everyday life, why has the relevance of Faith and Finance not been more prominent? Every age has a 'climate of opinion' and Carl Becker explained well its importance when treating the philosophes. ${ }^{17}$

Whether arguments command assent or not depend less upon the logic that conveys them than upon the climate of opinion in which they are sustained. What renders Dante's argument or St Thomas' definition meaningless to us is not bad logic or want of intelligence, but the medieval climate of opinion---those instinctively held preconceptions in the broad sense, the Weltanschauung or world pattern...To understand why we cannot easily follow Dante or St Thomas...it is necessary to understand...the nature of this climate of opinion.

This climate of opinion decides the content of the possibilities open to us, and as Herbert Butterfield noticed, it is the greatest obstacle to appreciating the importance of Christianity. ${ }^{18}$

Certain characteristic notions have become prevalent concerning the past, certain views about the process of things in time, and certain impressions ...of the panorama of the centuries... is in reality a more serious obstruction to Christianity than the natural sciences.

Anyone who has bothered to read the literature produced by and for everyday folk cannot fail to be impressed by the depth and intensity of Christian devotion present throughout society. It strains all credulity to accept the insignificance of these acts of piety in creating a society where certain virtues were widely approved and corresponding vices discouraged.

${ }^{17}$ Becker, Carl, The Heavenly City of the Eighteenth Century Philosophers (Yale, New Haven, 1932), p. 5.

${ }^{18}$ Butterfield, Herbert, Christianity and History (Collins, Fontana, London, 1957), p. 13 . 
Some authors, such as Jacob Viner, ${ }^{19}$ have striven hard to be fair, and Viner's writings provide some of the best clues on sources and issues. But such fairness has not been the norm. whether it be by the selection of material, or by their treatment of those selected, the Christian contribution has been presented as the 'opposition' to 'modernity.' In Peter Gay's widely acclaimed The Enlightenment, has the significant subtitle, 'The Rise of Modern Paganism,' which clarifies why the light was needed. It was to lead Europe away from the darkness of Christianity and the fears of a future life. In the early pages, Gay feels some scholarly pangs about the singularity of his heroes ${ }^{20}$

As I shall show over and over again...ideas and attitudes generally associated with atheistic, subversive philosophes...were the common property of most educated men in the eighteenth century...the war they [the philosphes] fought was half won before they joined it.

Not only is this claim of fighting a war half done poorly documented in what follows, Peter Gay failed to ask about those questions which were either ignored by the philosophes or where they fell behind their Christian contemporaries. The victory of such partial scholarship has been so total that, upon hearing William Temple lament the lack of Christian involvement with economics, Lord Keynes had to remind the Archbishop of Canterbury about the reality of Christian economic thought in the eighteenth century. Apart from Hume, Smith, Mandeville, Cantillon, and Bentham, Keynes said ${ }^{21}$ : 'I can think of no one important in the development of politico-economic ideas... who was not a clergyman, and in most cases a high dignitary of the Church.'

The extent of the misrepresentation of the role of Anglican Clergyman in promoting England's economic development is almost comical. The noted economic historian, R. H. Tawney, referring to the eighteenth century, said of the Anglican Church in the face of increasing wealth of

${ }^{19}$ Viner, Jacob, The Role of Providence in the Social Order: An Essay in Intellectual History (American Philosophical Society, Philadelphia, 1972). See also Viner, Jacob, "Religious Thought and Economic Society," in Jacques Melitz and Donald Winch (eds.), History of Political Economy, Vol. 10, No. 1 (Spring 1978).

${ }^{20}$ Gay, Peter, The Enlightenment: An Interpretation (Vintage Books, New York, 1968), pp. 22-23.

${ }^{21}$ Iremonger, F. A., William Temple (Oxford, Oxford University Press, 1948), pp. 438439. 
Britain that it did not give guidance because it had none to give. Tawney chooses Josiah Tucker as the embodiment of the new emptiness of Anglicanism. It is as though Capitalism, Riches and Wealth were necessarily immoral according to Tawney. Tucker, however, himself had met such attitudes and responded by expressing surprise at people who shouted 'Church in Danger' whenever any liberal economic measure were proposed. $^{22}$

I really think, the Church of England comes nearest to perfection of any since the Apostles days; and, under that persuasion, I confess it appears to me a most injurious Treatment, to be always representing her to be in a crazy, tottering Condition, ready to fall and never out of Danger.

Trapped between the omissions of its critics and the ignorance of its friends, Anglicanism has been hobbled. In the process, our capacity to understand the past has been numbed. Whether we agree or disagree with religion, there is little doubt that Christianity was the energy of the everyday lives of ordinary people in the West. In the words of Christopher Dawson, ${ }^{23}$

A Christian civilisation is certainly not a perfect civilization, but it is a civilization which accepts the Christian way of life as normal and frames its institutions as the organs of a Christian order. Such a civilsation actually existed for a thousand years, more or less. It was a living and growing organism---a great tree of culture which bore rich fruit in its season.

With this energy to rely upon, the civilization of the West was built.

\section{BIBLIOGRAPHY}

Becker, Carl. The Heavenly City of the Eighteenth Century Philosophers, 5. New Haven: Yale, 1932.

Butterfield, Herbert. Christianity and History, 13. Fontana, London: Collins, 1957.

${ }^{22}$ Tucker, Josiah, Reflections on the Naturalisation of Foreign Protestants (London, 1953), pp. 57-58.

${ }^{23}$ Dawson, Christopher, The Historic Reality of Christian Culture (Harper, New York, 1960), p. 36. For a longer and more eloquent statement of the point see Butterfield, op. cit., pp. 170-171. 
Dawson, Christopher. The Historic Reality of Christian Culture, 36. New York: Harper, 1960.

Fénelon, François. Lives of the Ancient Philosophers. New York, 1900.

Frank, Robert H. Luxury Fever. New York: Free Press, 1999.

Gay, Peter. The Enlightenment: An Interpretation, 22-23. New York: Vintage Books, 1968.

Iremonger, F. A. William Temple, 438-439. Oxford: Oxford University Press, 1948.

McPhail, Edward, and Salim Rashid, "Swift and Berkeley on Economic Development." In A History of Irish Economic Thought, edited by T. Boylan, R. Prendergast and J. Turner, 32-55. London: Routledge, 2010.

Rashid, Salim. "Richard Whately and Christian Political Economy at Oxford and Dublin." Journal of the History of Ideas 38 (1977): 144-147.

Rashid, Salim. "Richard Whately and the Struggle for Rational Christianity in the Mid Nineteenth Century." Historical Magazine of the Protestant Episcopal Church 47 (September 1978): 293-311.

Rashid, Salim. "Richard Jones and Baconian Historicism at Cambridge." Journal of Economic Issues 13 (March 1979): 159-176.

Rashid, Salim. "Anglican Clergymen-Economists and the Tithe Question in the Mid Nineteenth Century." Journal of Religious History 11 (Fall 1980): 6476.

Rashid, Salim. "Christianity and the Growth of Liberal Economics." Journal of Religious History 12 (1982): 221-232.

Rashid, Salim. "He Startled as If He Saw a Spectre: Proposal for American Independence." Journal of the History of Ideas 43 (July 1982): 439-460.

Rashid, Salim. "Josiah Tucker, Anglican Anti-Semitism, and the Jew Bill of 1753." Historical Magazine of the Protestant Episcopal Church 51 (June 1982): 191-201.

Rashid, Salim. "The Clergymen-Scholars of Economic Development." This World, no. 5 (Spring 1983): 94-106.

Rashid, Salim. "The Irish School of Economic Development: 1720-1750." The Manchester School of Social and Economic Studies LVI, no. 4 (December 1988): 345-369.

Rashid, Salim. "Berkeley's Querist and Its Influence." Journal of the History of Economic Thought 12 (Spring 1990): 38-60.

Rashid, Salim. "Christianity and Economics: Is There a Lacuna?" Anglican and Episcopal History LX, no. 1 (March 1991): 25-42.

Rashid, Salim. "Jonathan Swift, Wood's Halfpence and Anglican Passive Resistance." Presented at ASECS meetings in Los Angeles, 2015.

Rose, David. The Moral Foundation of Economic Behavior. Oxford: Oxford University Press, 2011. 
Semmel, Bernard. The Rise of Free-Trade Imperialism. Cambridge: Cambridge University Press, 1970.

Swift, Jonathan. 'Doing Good.' In The Prose Works of Jonathan Swift, Vol. 9, edited by Herbert Davis, 232-40. Oxford: Basil Blackwell, 1955 [1724].

Tucker, Josiah. Reflections on the Naturalisation of Foreign Protestants, 57-58. London, 1953.

Viner, Jacob. The Role of Providence in the Social Order: An Essay in Intellectual History. Philadelphia: American Philosophical Society, 1972.

Viner, Jacob. "Religious Thought and Economic Society." In Jacques Melitz and Donald Winch (eds.), History of Political Economy 10, no. 1 (Spring 1978).

Open Access This chapter is licensed under the terms of the Creative Commons Attribution 4.0 International License (http://creativecommons.org/licenses/ by $/ 4.0 /)$, which permits use, sharing, adaptation, distribution and reproduction in any medium or format, as long as you give appropriate credit to the original author(s) and the source, provide a link to the Creative Commons license and indicate if changes were made.

The images or other third party material in this chapter are included in the chapter's Creative Commons license, unless indicated otherwise in a credit line to the material. If material is not included in the chapter's Creative Commons license and your intended use is not permitted by statutory regulation or exceeds the permitted use, you will need to obtain permission directly from the copyright holder.

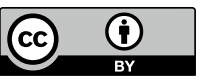




\section{Islamic Finance, Consumer Protection and Public Policy}

Faisal Kutty

\section{INTRODUCTION}

In a complaint filed against me years ago with the Law Society of Upper Canada (LSUC) (now renamed the Law Society of Ontario), the professional governing body of lawyers in Ontario, a client stated: "What this lawyer had me engage in is akin to me committing incest with my mother." The complaint arose from an "Islamic mortgage," the closing and registration of which had been facilitated by my office. Essentially an Islamic finance company, UM Financial ("UM"), had advanced the funds

1 "There are seventy-two types of riba, the least of which is like a man committing incest with his mother." Narrated by al-Tabaraani in al-Awsat, classified as saheeh by al-Albaani in Saheeh al-Jaami', no. 3537; See also Farooq, Mohammad Omar. December 27, 2009. "Riba, Interest and Six Hadiths: Do We Have a Definition or a Conundrum?" Review of Islamic Economics 13(1), 105-141; Farooq argues that this hadith used to expand the term riba to include all forms of interest does not hold up.

F. Kutty $(\bowtie)$

Dwayne O. Andreas School of Law, Barry University, Orlando, FL, USA

e-mail: fkutty@barry.edu

(C) The Author(s) 2020

T. Akram and S. Rashid (eds.), Faith, Finance, and Economy, https://doi.org/10.1007/978-3-030-38784-6_7 
to close a house purchase. UM claimed to have structured the transaction as a diminishing musharaka. ${ }^{2}$ My role was to ensure that the homebuyers, a couple, received clear title to the house being purchased and the investor (lender), in this case the Islamic finance company, UM, had security for their "Islamic loan." As part of the transaction, my office had the homebuyer clients sign standard real estate closing documents as well as documents governing and structuring the relationship between UM and the homebuyers. ${ }^{3}$ As is typical in such transactions, I was on a joint retainer for UM and the homebuyers.

Following the registration of the transaction, one of the buyers more thoroughly studied the documents and the structure, all of which were developed and prepared by UM. He concluded that the transaction was not "Islamic" or "Shari'ah-compliant."

Because my client's attempts to have the situation addressed by UM were unsuccessful, he filed a complaint against me with the LSUC. He was persistent and adamant in his position. He apparently harassed the LSUC non-stop, including showing up in person at its offices and essentially refusing to leave the premises unless it addressed the complaint. He also reportedly quoted to its members the hadith mentioned in footnote one.

The LSUC responded by dispatching its chief investigation counsel and a forensic auditor to deliver the complaint notice to me personally. ${ }^{4}$ Its members were obviously concerned, and I spent some time educating them about Islamic finance in my boardroom. The complaint was eventually dismissed with the direction that going forward I had to advise my clients that I was not providing them with "Islamic finance" or "Shari'ahcompliance" advise. ${ }^{5}$

${ }^{2} \mathrm{~A}$ diminishing musharakah is a diminishing partnership.

In a diminishing partnership (also known as a "declining balance partnership" or "declining musharakab"), one partner's share is drawn down while it is transferred to another partner until the entire sum is passed over. Such a structure is common in homebuying where the lender (generally a bank) buys a property and receives payment from a buyer (via monthly rent payments) until the whole balance is paid off.

For more information, see Musharakah, https://www.investopedia.com/terms/m/ musharakah.asp\#ixzz5Yq5Mbfzd.

${ }^{3}$ In a conventional mortgage transaction, our office would have prepared standard real estate documents and the bank's documents.

${ }^{4}$ Other lawyers with whom I spoke at the time were shocked to learn that the Law Society officials showed up in person.

5 There is also the related issue that lawyers are not insured to provide non-legal advice. 
This incident illustrates a number of issues, but for the purposes of this chapter, I will focus on the following:

1. The importance of faith or religion for some people when it comes to financial decisions; and

2 . The potential consumer protection concerns with respect to regulating what is or what is not "Islamic" or "Shari'ah-compliant" in western financial markets.

These two issues run as the central themes through the discussion in this paper. This chapter is organized into four parts. Part I provides an overview of the origins, sources, and history of Islamic finance. Part II provides an introduction to the basic principles of Islamic finance. Part III touches upon some of the regulatory and policy concerns and issues. Part IV concludes with some observations about future prospects and recommendations.

\section{Origins, Sources ANd Brief History}

My client's complaint centered around the concern that the loan he negotiated, and that my office had helped him finalize, was not consistent with Islamic finance rules. Islamic finance rules evolved out of Islamic economics, which in turn takes its inspiration from the Shari'ah. ${ }^{6}$ The Islamic financial system is based on religious teachings that emphasize that everything belongs to God and that human beings are accountable to God for their conduct (and intentions) on earth. Human beings have been tasked to be trustees over God's wealth and must discharge this role within a framework that prioritizes, among other things, social and economic justice. The ethical, moral, social, and legal principles at the core of Islamic finance are derived from the Shari'ah (loosely and inaccurately referred to as Islamic law). ${ }^{7}$ It essentially involves balancing the material

\footnotetext{
${ }^{6}$ Shari'ah and Islamic law will be used throughout the paper though the two do not necessarily have the same meaning. Some writers inaccurately use them interchangeably. Kutty, Faisal. 2010. "The Myth and Reality of 'Shari'a Courts' in Canada: A Delayed Opportunity for the Indigenization of Islamic Legal Rulings." University of St. Thomas Law Journal 7, 559.

${ }^{7}$ For an explanation of Shari'ah, see Kamali, M.H. 1989. "Source, Nature and Objectives of Shari'ah." Islamic Quarterly 33, 211-233; Part 5 of Kutty, Faisal. 2010. "The
} 
and the spiritual as well as the individual and collective interests within a God-centered ethical framework.

The Islamic finance system seeks to provide banking and finance services that comply with Islamic principles. ${ }^{8}$ It must operate within ethical and religious constraints, but it should also further social and economic justice. By complying with Islamic principles, the Islamic finance system aims to achieve a more equitable distribution of wealth and income, and it encourages full employment, socioeconomic justice, and stability. ${ }^{9}$ In essence, it can be described as a modified free enterprise system that locates itself in the middle of the spectrum between socialism and capitalism.

Islamic finance, in its broadest sense, has existed since the early years of Islam, starting with the social and economic justice teachings of the Prophet Muhammad (Peace be upon him-[pbuh]) ${ }^{10}$ as detailed in the Quran and Sunnah (teachings and sayings attributed to the Prophet). ${ }^{11}$ Islam teaches that it is the continuation and culmination of the messages sent to previous prophets and messengers. Consistent with this view, at its core many of the central teachings and beliefs in Islam, including teachings on social and economic justice, are very similar to those of other major religious traditions. Historians of early Islamic civilization have documented that banking activities similar to those performed today took

Myth and Reality of 'Shari'a Courts' in Canada: A Delayed Opportunity for the Indigenization of Islamic Legal Rulings," University of St. Thomas Law Journal 7, 559; see also Kutty, Faisal. September 24, 2014. "The Kutty 'Islamic Law' Flowchart," http://www. islamiclawflowchart/.

${ }^{8}$ Maljichi, Drita N. 2014. "Islamic Financial Markets and Institutions." Vizione 21, 291-292; Shaikh, Salman Ahmed. January 14, 2010. "A Brief Review \& Introduction to Practiced Islamic Banking \& Finance." Retrieved from https://ssrn.com/abstract= 1536943 or http://dx.doi.org/10.2139/ssrn.1536943; El-Gamal, Mahmoud A. 2006. Islamic Finance: Law, Economics and Practice. Cambridge: Cambridge University Press.

${ }^{9}$ El-Ghattis, Nedal. "Islamic Banking's Role in Economic Development: Future Outlook." Retrieved from https://pdfs.semanticscholar.org/cfc6/ 6f09435a5445c2cadd2d18937823635c5d3d.pdf; Iqbal, Zamir and Mirakhor, Abbas. 2011. An Introduction to Islamic Finance: Theory and Practice, 2nd ed. Asia: Wiley.

${ }^{10}$ Peace be upon him (pbuh) is a term customarily used when referring to the Prophet Muhammad.

${ }^{11}$ El-Gamal, Mahmoud A. 2006. Islamic Finance: Law, Economics and Practice. Cambridge: Cambridge University Press; Reda, Ayman. 2018. Prophecy, Piety, and Profits: A Conceptual and Comparative History of Islamic Economic Thought. New York: Palgrave Macmillan. 
place from the early days of Islamic civilization. ${ }^{12}$ In fact, the Islamic empire had a well-developed financial system, complete with a legislative system governing transactions, a judicial system enforcing contracts, different commercial papers and banknotes, and licensed bankers, which contributed to the development of modern banking practices. ${ }^{13} \mathrm{How}^{-}$ ever, under the influence of European colonizers, many Islamic countries adopted Western banking models in the nineteenth century. It was not until the mid-twentieth century that Islamic financial institutions began to reemerge, partly driven by political Islam and a renewed sense of Islamic identity. ${ }^{14}$ Since then, the global market for Islamic finance has become one of the fastest-growing segments of global finance with a growth rate between 10-12\% annually and a "Shari'ah-compliant" industry worth well over \$2 trillion USD in 2015 and projected to grow to $\$ 3.2$ trillion by 2020 according to Thomson Reuters. ${ }^{15}$

Once largely limited to the Middle East and Southeast Asia, "Shari'ahcompliant" finance and products are gaining attention outside these traditional markets. It made its first appearance in the West in 1978 with

12 Alharbi, Ahmad. 2016. "Development of Islamic Finance in Europe and North America: Opportunities and Challenges." International Journal of Islamic Economics and Finance Studies 2(3), 109-110; Udovitch, A. 1979. "Bankers Without Banks: Commerce, Banking and Society in the Islamic World of the Middle-Ages." In The Dawn of Modern Banking (ed.) by the Centre for Medieval and Renaissance Studies, Los Angeles: University of California; Al-Hamdani, Khaled. 2000. al-Nizam al-Masrafi fi al-Dawlah al-Islamiyah (The Banking System in the Islamic State); Islamiyat al-Maarifa, Winter, pp. 15-41; Labib, S. March 1969. "Capitalism in Medieval Islam." Journal of Economic History 29(1), 79-140; Issawi, C. 1966. The Economic History of the Middle East 18001914. Chicago: University of Chicago Press; Chachi, Abdelkader. 2005 A.D/1426 A.H. "Origin and Development of Commercial and Islamic Banking Operations." Journal of King Abdulaziz University: Islamic Economics 18(2), 3-25.

13 Ibid.

${ }^{14}$ Alharbi, Ahmad. 2016. "Development of Islamic Finance in Europe and North America: Opportunities and Challenges." International Journal of Islamic Economics and Finance Studies 2(3), 112; Zaman, Arshad. 2011. "Sayyid Abu'l A'la Maududi on Islamic Economics: A Review Article." Islamic Studies, 50(3-4), 303-323. Retrieved from https://ssrn.com/abstract=2225711; Kuran, Timur. 2004. Islam and Mammon: The Economic Predicaments of Islamism. Princeton: Princeton University Press.

15 Thomson Reuters. 2015. Canada Islamic Finance Outlook 2016 at 58, http://www. tfsa.ca/storage/reports/Canada_Islamic_Finance_2016.pdf. See also Staff Writer. August 7, 2016. "Islamic Finance Assets Forecast to be Worth $\$ 3.2 \operatorname{trn}$ by 2020." Arabian Business, https://www.arabianbusiness.com/islamic-finance-assets-forecast-be-worth3-2trn-by-2020-641156.html. 
the establishment of the Islamic Finance House Universal Holding S.A. in Luxembourg. ${ }^{16}$ Today London has a significant presence in Islamic Finance. ${ }^{17}$

North America, considered to have one of the most stable banking systems in the world, has also witnessed growing interest in Islamic finance. 18 "Shari'ah-compliant" products have been offered in Canada and the United States since the 1980s. ${ }^{19}$ The significant, relatively affluent, and religiously observant Muslim population in North America represents a substantial consumer market for investments, pensions, insurance, mortgages, and commercial businesses, as along with day-to-day banking. Islamic finance only began to get real traction in the United States in 1990s, when "the New York branch of the United Bank of Kuwait obtained two interpretive letters issued by the Office of the Comptroller of the Currency to offer Islamic retail banking services in the country." 20 The first letter, issued in 1997, permitted the use of ijarah, ${ }^{21}$ whereby the bank would act as a "riskless principal," buying real estate at the request of the lessee, then leasing it back to them until the final payment, at which time the lessee would be given title. ${ }^{22}$ The second letter, issued in 1999, allowed murabaha-based financial products. As in the previous

${ }^{16}$ European Central Bank (Occasional Paper Series, No. 146, June 2013), "Islamic Finance in Europe." Retrieved from https://www.ecb.europa.eu/pub/pdf/scpops/ ecbocpl46.pdf; Alharbi, Ahmad. 2016. "Development of Islamic Finance in Europe and North America: Opportunities and Challenges." International Journal of Islamic Economics and Finance Studies 2(3), 112; di Mauro, Filippo, Caristi, Pierluigi, Couderc, Stéphane, Di Maria, Angela, Ho, Lauren, Kaur Grewal, Baljeet, Masciantonio, Sergio, Ongena, Steven R.G., Zaheer, Sajjad. April 15, 2013. "Islamic Finance in Europe." ECB Occasional Paper No. 146. Retrieved from SSRN: https://ssrn.com/abstract=2251204.

${ }^{17}$ Langah, Waseem Ahmad. February 25, 2009. Islamic Banking in the UK: Challenges and Opportunities. Retrieved from https://ssrn.com/abstract=1349170.

${ }^{18}$ Alharbi, Ahmad. 2016. "Development of Islamic Finance in Europe and North America: Opportunities and Challenges." International Journal of Islamic Economics and Finance Studies 2(3), 112; Thomson Reuters. 2015. Canada Islamic Finance Outlook 2016 at 58, http://www.tfsa.ca/storage/reports/Canada_Islamic_Finance_2016.pdf.

${ }^{19}$ Ibid. at 124 .

${ }^{20}$ Ibid.

${ }^{21}$ See discussion below.

${ }^{22}$ Alharbi, Ahmad. 2016. "Development of Islamic Finance in Europe and North America: Opportunities and Challenges." International Journal of Islamic Economics and Finance Studies 2(3), 124-125. 
scheme, the bank had to act again as a "riskless principal," thereby permitting the activity. While the bank ceased operations in the United States in 2000, it bought and leased sixty homes for American Muslims. ${ }^{23}$ Since 2000, many small Islamic financial institutions have entered the market, and many conventional financial institutions have begun to offer Islamic products with varying degrees of compliance with Islamic principles. ${ }^{24}$

Islamic finance is also gaining interest in Canada and is expected to increase as Canada has a large, growing, young, and observant Muslim population. ${ }^{25}$ The 2011 National Household Survey found Muslims make up $3.2 \%$ of Canada's population. ${ }^{26}$ The community is expected to reach $6.6 \%$ by $2030 .{ }^{27}$ While some Islamic financial products are available, no major financial institution has successfully marketed any "Shari'ah-compliant" products or services. ${ }^{28}$ The first Islamic financial body in Canada - the Islamic Co-operative Housing Corporation Ltd., a grassroots, community-based project-was established in Toronto in 1979.29 Since then, several other Islamic financial institutions have been established throughout Ontario and Quebec. One such company, UM Financial, founded in 2004, became one of the primary Islamic financial providers in Canada. It partnered with Central 1 Credit Union of Canada and marketed "Islamic mortgages." From 2006 to 2007, UM Financial provided $\$ 86.1$ million in home financing. The company was essentially relabeling, using legal fictions/assignments, drafting parallel documents, and clouding disclosure to unsophisticated buyers.

\footnotetext{
23 Ibid. at 125 .

24 Ibid. at 126.

25 Ibid.

${ }^{26}$ Statistics Canada. 1991. 2011 National Household Survey: Data Tables, 99-010X2011032. Ottawa.

27 Ibid.

28 Ibid.

${ }^{29}$ Khan, Sheema. April 7, 2008. "It's Time to Take Interest in Islamic Financing." The Globe and Mail, https://www.theglobeandmail.com/opinion/its-time-to-takeinterest-in-islamic-financing/article22501330/; see also http://www.ansarhousing.com/ about_us.aspx.
} 
The company declared bankruptcy in 2011, and its founder and chief Shari'ah advisor were charged with fraud. ${ }^{30}$

The fact remains that there is a growing appetite for Islamic finance products even in North America. Inevitably, there will be unscrupulous actors who prey on the lack of knowledge among consumers both of finance and Islamic principles, non-existence of religious standards or regulatory bodies, lack of government oversight and issues and obstacles in structuring "Shari'ah-compliant" products and transactions.

\section{Introduction to the Principles of Islamic Finance}

Islamic finance is differentiated from conventional finance by the fact that Islamic finance is God-centered and informed by principles of Islamic law.

\section{Probibitions}

Islamic finance has become synonymous with a system that, at its core, prohibits: (1) usury (riba); (2) taking excessive or unnecessary risk or gambling where one party benefits only due to the loss of the other (qimar and maysir); (3) uncertain transactions/speculation (gharar); and (4) the limitation in dealing with products, industries and services considered prohibited ( haram), such as alcohol, gambling, illegal drugs, certain weapons, pornography, and other areas deemed harmful to society or the individual, etc.

\section{Riba ("Usury")}

For most people aware of Islamic finance, the first thing that comes to mind is the prohibition of riba, which is understood by most Muslims as interest per se. The basis for this prohibition of riba is said to be rooted in

${ }^{30} \mathrm{Ha}$, Tu Thanh. 2014. "RCMP charge missing Toronto Financier with \$4.3Million Mortgage Fraud." The Globe and Mail, https://www.theglobeandmail.com/ news/national/rcmp-charge-missing-toronto-financier-with-43-million-mortgage-fraud/ article16972349/; Nasser, Shanifa. 2017. "Muslim Mortgage Kingpin Led Investigators on 'Treasure Hunt' for Missing Gold: Crown.” CBC News, https://www.cbc.ca/ news/canada/toronto/omar-kalair-muslim-madoff-shariah-mortgages-1.4390002; Pasha, Shaheen and French, Cameron. 2011. "Canada Bankruptcy May Hurt Islamic Finance in N. America." Reuters, https://www.reuters.com/article/canada-islamic-bankruptcyidUSL5E7MT3KY20111205. 
the Quran and the teachings of the Prophet Muhammad (peace be upon him), the Sunnah. Contrary to the understanding of most Muslims, the definition of riba has been contested and evolving throughout Islamic history and is often the subject of intense debate among Islamic jurists, scholars, and bankers. ${ }^{31}$ A conservative/orthodox understanding, which is the majority view, holds that the term applies to any form of interest and precludes its payment or collection. ${ }^{32}$ A minority, but growing, interpretation opines that riba refers to "usury" or excessive compounded interest. ${ }^{33}$ The two underlying principles that are used as the basis to prohibit riba are the Quran's ${ }^{34}$ stipulation that only active trading serves as the basis for increasing wealth and the unfairness of manipulating desperate "poorer members of society by unscrupulous merchants." 35 The prohibition and the principles behind riba have historically been central tenets of

${ }^{31}$ Azhar, Rauf. November 15, 2009. Economies of an Islamic Economy, Themes in Islamic Studies, Vol. 6, https://doi.org/10.1163/ej.9789004179370.i-470; Fadel, Mohammad Riba. Forthcoming. "Efficiency, and Prudential Regulation: Preliminary Thoughts," Wisconsin International Law Journal 25(4), 656; Islamic Law and Law of the Muslim World Paper No. 08-18; El-Gamal, Mahmoud A. 2003. "Interest' and the Paradox of Contemporary Islamic Law and Finance." Fordham International Law Journal 27(1), Article 6, https://pdfs.semanticscholar.org/8cb7/0cc8baaf91 lad52f932205al722f76e3f049.pdf; Karasik, Theodore, Wehrey, Frederic, and Strom, Steven. 2006. "Islamic Finance in a Global Context: Opportunities and Challenges." Chicago Journal of International Law $7(2), 379$.

${ }^{32}$ Kuran, Timur. 2004. Islam and Mammon: The Economic Predicaments of Islamism. Princeton: Princeton University Press; Farooq, Mohammad Omar. 2007. "Stipulation of Excess in Understanding and Misunderstanding Riba: The Al-Jassas Link." Arab Law Quarterly 21(4), 285-316.

${ }^{33}$ Arberry, Arthur John. 1996. The Koran Interpreted: A Translation. New York: Simon and Schuster; Kuran, Timur. 2004. Islam and Mammon: The Economic Predicaments of Islamism. Princeton: Princeton University Press; Farooq, Mohammad Omar. 2007. "Stipulation of Excess in Understanding and Misunderstanding Riba: The Al-Jassas Link." Arab Law Quarterly 21(4), 285-316.

${ }^{34}$ The verses against interest ( $r i b a$ ) can be found in the Surah Al-Baqara chapter, verses 275-280, the Al-Rom chapter, verse 39, and the AI-Nisa chapter, verses 159-160; e.g. "Those who swallow usury cannot arise except as he arises whom the devil prostrates by (his) touch. That is because they say trading is like usury. And Allah has allowed trading and forbidden usury" (Quran, 2.275).

${ }^{35}$ See Aziz, Zeti A. 2008. "Enhancing Interlinkages and Opportunities: The Role of Islamic Finance." Islamic Finance: Global Trends and Challenges 18, 5-7; National Bureau of Asian Research ed. (quantifying annual growth rate of Islamic finance at fifteen to twenty percent). 
several major religions (e.g., Judaism ${ }^{36}$ and Christianity ${ }^{37}$ ). According to some observers, around 1000 A.D. there existed little difference between Christian Europe and the territories under Muslim rule pertaining to their attitudes toward interest. ${ }^{38}$ Indeed, the Catholic Church lifted the ban on interest only in the mid-nineteenth century. ${ }^{39}$ Moreover, there are banks in Israel that cater to Jews who refuse to pay or take interest. ${ }^{40}$

\title{
Qimar ("Excessive Risks") and Maysir ("Wagering”)
}

Transactions or dealings that involve unnecessarily or unreasonably risky undertakings in the hopes of achieving something are also prohibited. ${ }^{41}$ This includes qimar, which literally means betting and wagering. ${ }^{42}$ Qimar refers to taking ownership of something valuable ( $m a l)$ through

\begin{abstract}
${ }^{36}$ In Judaism, interest was prohibited as per the following: "If you lend money to any of My people with you who is poor, you shall be to him as a creditor, and you shall not exact interest from him" (Ex. 22:25); "He that hath not given this money upon usury; nor taken reward against the innocent. He that doeth these things: shall never fall" (Psalm 15); "To a foreigner you may lend upon interest, but to your brother you shall not" (Deut. 23.19); See Reda, Ayman. 2018. Prophecy, Piety, and Profits: A Conceptual and Comparative History of Islamic Economic Thought, New York: Palgrave Macmillan. (Jews, Christians, etc.); see also Ahmad, Shaikh Mahmud. 1981. "Judaism and Interest." Islamic Studies 20(1), 47-82.

${ }^{37}$ In Christianity, it is discouraged per the following: "Love your Enemies and Do Good, Lend, Expect Nothing in Return" (Luke 6:35); See Reda, Ayman. 2018. Prophecy, Piety, and Profits: A Conceptual and Comparative History of Islamic Economic Thought. New York: Palgrave Macmillan (jews, Christians, etc.); see also Mayyasi, Alex. 2017. "Of Money and Morals." Aeon. Retrieved from https://aeon.co/essays/how-did-usury-stopbeing-a-sin-and-become-respectable-finance.
\end{abstract}

${ }^{38}$ Schoon, Natalie and Nuri, Julinda. 2012. "Comparative Financial Systems in Judaism, Christianity and Islam: The Case of Interest." Retrieved from https://ssrn.com/abstract= 2126503 or http://dx.doi.org/10.2139/ssrn.2126503.

${ }^{39}$ Weber, Max. 1979. Economy and Society. Berkeley, CA: University of California Press.

${ }^{40}$ Seznec, Jean-François. 1999. "Ethics, Islamic Banking and the Global Financial Market." Fletcher Forum of World Affairs 23(1), 161.

${ }^{41}$ Uddin, Md Akther. 2015. Principles of Islamic Finance: Prohibition of Riba, Gharar and Maysir. Kuala Lumpur, Malaysia: INCEIF, https://mpra.ub.uni-muenchen. de/67711/1/MPRA_paper_67711.pdf; Abdullah, Atikullah Hj. 2013. "The Elements of Qimar (Wagering) and Gharar (Uncertainty) in the Contract of Insurance Revisited," https://ibtra.com/pdf/journal/v9_n2_article5.pdf.

42 Ibid. 
some form of wager. ${ }^{43}$ Islamic law unequivocally prohibits every zero-sum scenario through wagering on very risky outcomes.

This prohibition also extends beyond qimar to maysir, which is broader and extends to all kinds of gambling and games of chance. ${ }^{44}$ Evolving out of the pre-Islamic practice of divining arrows whereby seven persons gambled for shares (portions) of an allotted prize, the objection is to the fact that the agreement between the players is based entirely on wishful odds that have no real statistical probability.

In essence, these prohibitions aim at preluding "effortless gain" generated from any dealings." 45 It is quite obvious that there will be a wide range of diverse opinions on what would or would not fall into these categories.

\section{Gharar ("Probibition on Excessive Risk and Deception")}

Another central pillar of Islamic finance is the prohibition of excessive risk, uncertainty and deception all grouped under the heading of gharar. ${ }^{46}$ Obviously, business and investment always involve elements of risk, but disproportionate uncertainty or risk would violate Islamic principles. This of course rules out speculative trading. According to Muhammad Ayub, Islamic jurists have defined gharar as "the sale of a thing which is not present at hand, or the sale of a thing whose aqibab (consequence) is not known, or a sale involving hazard in which one does not know whether it will come to be or not." 47 The prohibition against gharar tends to prohibit major financial products, according to most but not all Islamic finance scholars, such as "forward contracts, swap agreements, hedges,

43 Ibid.

44 Ibid.

${ }^{45}$ Nizami, Shah M. 2011. "Islamic Finance: The United Kingdom's Drive to Become the Global Islamic Finance Hub and the United States' Irrational Indifference to Islamic Finance." Suffolk Transnational Law Review, 34(1), 219.

${ }^{46}$ Uddin, Md Akther. 2015. Principles of Islamic Finance: Prohibition of Riba, Gharar and Maysir. Kuala Lumpur, Malaysia: INCEIF, https://mpra.ub.uni-muenchen. de/67711/1/MPRA_paper_67711.pdf; Abdullah, Atikullah Hj. 2013. "The Elements of Qimar (Wagering) and Gharar (Uncertainty) in the Contract of Insurance Revisited," https://ibtra.com/pdf/journal/v9_n2_article5.pdf.

${ }^{47}$ Ayub, Muhammad. 2007. Understanding Islamic Finance, 58. West Sussex: Wiley. Retrieved 30 August 2018. 
options, derivatives, and financial insurance." ${ }^{28}$ It also prohibits the sale of things that do not yet exist, which some scholars have interpreted to include, for example, fish that a fishing boat setting out to sea may catch on its expedition, a crop that has yet to be planted, and even an unborn animal. $^{49}$

\section{Haram ("Probibited") Goods and Services}

Another dictate is that Islamic financial institutions must not be involved in areas prohibited by Islamic law, such as alcohol, tobacco, pork, gambling, pornography, and weapons. ${ }^{50}$ The degree in kind and level to which these are adhered to depend on the philosophy and strictness of the scholar or Shari'ah body, which may range from absolute prohibition to those who allow it to within a de-minimis threshold. Some of these prohibitions, to varying degrees, are similar to those found in the socially responsible investing (SRI) movement within conventional banking. ${ }^{51}$ In fact, in this context there may be some similarities between conventional

${ }^{48}$ Nizami, Shah M. 2011. “Islamic Finance: The United Kingdom's Drive to Become the Global Islamic Finance Hub and the United States' Irrational Indifference to Islamic Finance." Suffolk Transnational Law Review 34(1), 219; See also Richardson, Christopher F. 2006. "Islamic Finance Opportunities in the Oil and Gas Sector: An Introduction to an Emerging Field." Texas International Law Journal 42, 119-123; Nehad, A. and Khanfar, A. 2016. "A Critical Analysis of the Concept of Gharar in Islamic Financial Contracts: Different Perspectives." Journal of Economic Cooperation and Development 37(1), 1-24, http:/ /www.sesric.org/pdf.php?file=ART14103001-2.pdf.

${ }^{49}$ Nehad, A. and Khanfar, A. 2016. "A Critical Analysis of the Concept of Gharar in Islamic Financial Contracts: Different Perspectives." Journal of Economic Cooperation and Development 37(1), 1-24, http://www.sesric.org/pdf.php?file=ART14103001-2.pdf.

Waemustafa, W. 2015. "Theory of Gharar and Its Interpretation of Risk and Uncertainty from the Perspectives of Authentic Hadith and the Holy Quran: Review of Literatures," http://repo.uum.edu.my/18860/1/Wae_gharar.pdf.

${ }^{50}$ Jamaldeen, Faleel. "Seven Prohibited Industries in Islamic Financial Investments," https://www.dummies.com/personal-finance/islamic-finance/seven-prohibited-industriesin-islamic-financial-investments/; El-Gamal, Mahmoud A. 2006. Islamic Finance: Law, Economics and Practice. Cambridge: Cambridge University Press.

${ }^{51}$ Hayat, Usman. 2013. "Islamic Finance and Socially Responsible Investing." CFA Institute News, https://www.cfainstitute.org/-/media/documents/article/cfa-magazine/ 2013/cfm-v24-n2-2.ashx; Ferruelo, Elizabeth. 2012. "Why Socially Responsible Investing and Islamic Finance is on the Rise." Forbes, https://www.forbes.com/sites/ ashoka/2012/11/01/why-there-is-high-growth-potential-in-the-nexus-between-sociallyresponsible-investing-and-islamic-finance/\#5813dab0e3fl. 
and Islamic finance. Particularly, since the financial crisis of 2008, there has been pressure within Western countries for banking to become simpler, less reliant on highly leveraged capital structures, and for a more deeply ingrained sense of ethics. ${ }^{52}$

\section{Islamic Finance Products and Mechanisms}

The foregoing restrictions do not mean that Islamic finance is averse to business or taking calculated and reasonable risks to generate a profit. On the contrary, Islam is understood to encourage trade and the productive use of capital. ${ }^{53}$ As a result of these restrictions around riba, qimar/maisir, gharar, and the prohibition on engaging with haram goods and services, Islamic financial institutions have had to devise products and services that work around these "impediments" while generating profits. One of the fundamental conceptual shifts induced by Islamic finance is that transactions must be linked to assets using equity-based instruments and contracts as opposed to debt-based instruments. It also means that, at least in theory, there ought to be more emphasis on social justice, fairness, and ethical concerns. Provided that it is equity-based and avoids the above prohibitions, profits can be generated through the reallocation and management of risk and reward between capital providers and users. ${ }^{54}$

At its simplest level conventional financing takes the form of equity or debt. ${ }^{55}$ Equity financing means giving an ownership interest or shares of common stock to an investor with its attendant risk of investment loss in exchange for the opportunity to participate in gains or profits. Debt financing involves borrowing money and not giving up ownership or an interest in the asset or going concern. The creditor or lender has its

$$
{ }^{52} \text { Ibid. }
$$

${ }^{53}$ Archer, Simon and Karim, Rifaat Abdel. 2002. Islamic Finance: Growth and Innovation. London: Euromoney Books.

Azhar, Rauf. November 15, 2009. Economies of an Islamic Economy, Themes in Islamic Studies, Vol. 6, https://doi.org/10.1163/ej.9789004179370.i-470.

${ }^{54}$ El Qorchi, Mohammed. 2005. "Islamic Finance Gears Up." Finance and Development 42(4), 46; El-Gamal, Mahmoud A. 2006. Islamic Finance: Law, Economics and Practice. Cambridge: Cambridge University Press.

${ }^{55}$ Hanif, Muhammad. 2014. "Differences and Similarities in Islamic and Conventional Banking." International Journal of Business and Social Sciences 2(2), 26. 
loan secured through a mortgage or through personal property security regimes. ${ }^{56}$ In some cases it may even be an unsecured loan. The debtor must, of course, invariably pay a fixed return in the form of interest, which a majority of Islamic scholars translate as riba. Islamic-compliant products attempt to shift this paradigm toward joint-venture and limited partnership structures whereby the profit and loss are shared in agreedupon proportions. To comply with the various rules and prohibitions, numerous investment vehicles and contracts have been developed over the years that have been approved by Islamic jurists (although not all instruments and structures and their permutations or iterations are accepted by all scholars). These include, among others, murabahah, ijarah, mudharabah, musharaka, istisna, takaful, and sukuk. ${ }^{57}$

\section{Murabahah ("Rent to Own”)}

The most commonly used transaction is the murabahah, where a commodity or asset is purchased by the financier for the buyer, who then pays the cost plus a fixed "profit" or mark-up over a period of time. ${ }^{58}$ The purchase and sale price, costs, and the profit margins must be clearly agreed to between the parties at the outset. The asset must remain under the ownership of the financing institution until the agreed marked-up price for the asset is fully paid by the customer. ${ }^{59}$ In some ways, it is similar to a rent-to-own type of arrangement. Most Islamic finance companies offering "Shari'ah-compliant" mortgages use a variation of this model, or at least claim to do so. One of the major problems from an Islamic perspective is that, contrary to the theory, in practice the Islamic finance company does not keep title for liability, practicality, or out of legal/regulatory

${ }^{56}$ Security is registered in a land registry office when real property is involved or through a personal property security registration regime on a priority and attachment basis.

${ }^{57}$ Hussain, Mumtaz, Shahmoradi, Asghar, and Turk, Rima. 2015. "An Overview of Islamic Finance," IMF Working Paper, https://www.imf.org/external/pubs/ft/wp/ 2015/wpl5120.pdf; El-Gamal, Mahmoud A. 2006. Islamic Finance: Law, Economics and Practice. Cambridge Cambridge: University Press.

${ }^{58}$ Qazi, Irfan. 2008. "Murabaha Financing vs. Lending on Interest.” Retrieved from https://ssrn.com/abstract=1803651 or http://dx.doi.org/10.2139/ssrn.1803651; Rammal, Hussain Gulzar. 2004. "Financing Through Musharaka: Principles and Application." Business Quest. Retrieved from https://ssrn.com/abstract $=1442430$.

${ }^{59}$ Ibid., Qazi, Irfan. 
considerations. When one factors in the use of security in the form of a mortgage versus keeping title, amortization schedules that do not match the term, terms that are less than the length required to pay off the full value, rates pegged to the market interest rate, etc., it becomes easy to imagine how the lines between interest/profit and conventional/Islamic finance get blurred.

A traditional murabahah structure is also employed quite often in the trade finance context. ${ }^{60}$ For instance, a customer needs to buy goods but cannot afford funds up front, but there is a financier prepared to facilitate the transaction by advancing the funds. The financier buys the goods, paying full price on delivery, and upon receipt of the goods immediately sells it at a mark-up (a single payment at a later date or pre-agreed schedule) within an agreed-upon time. Depending on the reference points used, profit calculation formula, and amortization schedule used, this murabahab could easily mirror a conventionally financed transaction with Arabic terminology substitutions.

It works slightly differently in the commodity contexts. In the commodity context, upon receipt of the murababah financed goods, the customer will immediately sell the goods back into the market with a mark-up immediately or in a deferred transaction. ${ }^{61}$ Unlike a traditional murabahah (where the financing is to facilitate acquisition of a property or equipment that the customer actually wants), a commodity murabahah structure can be used to facilitate the flow of funds to an entity, even where the entity does not want the underlying commodity (raising the concern about money making money in the Islamic context). The only additional requirement is that the commodity is not haram.

Murabahah finance appears to be the closest to a conventional loan and the most straight-forward to effect. For this reason, as well as the way that murabahab is used today by Islamic finance companies, the murababah structure has attracted the most criticism from Islamic scholars and

${ }^{60}$ Murabahah Trade Financing. Maldives Islamic Bank, http://www.mib.com.mv/ pages/view/murabahah-trade-financing; El-Gamal, Mahmoud A. 2006. Islamic Finance: Law, Economics and Practice. Cambridge: Cambridge University Press.

${ }^{61}$ For an explanation of murabaha, see https://nscpolteksby.ac.id/ebook/files/Ebook/ Accounting/Ethica\%20Handbook\%20of\%20Islamic\%20Finance/25.\%20MURABAHA.pdf; El-Gamal, Mahmoud A. 2006. Islamic Finance: Law, Economics and Practice. Cambridge: Cambridge University Press. 
finance experts for violating the spirit of Shari'ah principles while blindly adhering to form.

\section{Ijarah ("Lease Finance")}

Another commonly used transaction is the ijarah, where the financier buys an asset from a party to lease to another party or from the customer to then lease it back to the customer for a fixed period, after which the lessee commits to repurchase the asset. ${ }^{62}$ The financial institution is entitled to a predetermined rental fee. ${ }^{63}$ In essence, the ijarah structure is the equivalent of a traditional finance lease. In the Islamic context, it is arguably the second most common instrument, most often used for real property or asset financing. The asset is essentially sold to the customer at the end of the ijarah contract (or in the event of default) for a pre-agreed buyout price plus any accrued and unpaid rent. In some situations, the underlying asset may be split up (actually or theoretically on a percentage basis) to allow for a sculpted reduction in the purchase price payable or to allow for partial (voluntary or involuntary) payments of the purchase price during the term of the ijarah contract (to mirror amortization or early repayment under a conventional term loan). Again, Islamic jurists have differences of opinion as to what is permitted and what is not in the context of ijarah.

\section{Mudharabah ("Profit/Loss Sharing”)}

Mudharabah refers to a profit-sharing contractual agreement between a financial institution or investor and an entrepreneur. ${ }^{64}$ This can be

${ }^{62}$ Hussain, Mumtaz, Shahmoradi, Asghar, and Turk, Rima. 2015. "An Overview of Islamic Finance," IMF Working Paper, https://www.imf.org/external/pubs/ft/wp/ 2015/wp15120.pdf; El-Gamal, Mahmoud A. 2006. Islamic Finance: Law, Economics and Practice. Cambridge: Cambridge University Press.

${ }^{63}$ Zaher, Tarek S. and Hassan, M. Kabir. 2001. "A Comparative Literature Survey of Islamic Finance and Banking." Financial Markets, Institutions \& Instruments 10(4), 155-199.

${ }^{64}$ Hussain, Mumtaz, Shahmoradi, Asghar, and Turk, Rima. 2015. "An Overview of Islamic Finance," IMF Working Paper, https://www.imf.org/external/pubs/ft/wp/ 2015/wp15120.pdf; El-Gamal, Mahmoud A. 2006. Islamic Finance: Law, Economics and Practice. Cambridge: Cambridge University Press; Shaikh, Salman Ahmed. 2011. "A Critical Analysis of Mudarabah \& A New Approach to Equity Financing in Islamic 
viewed as "venture capital." At its core, it is a contract that provides for profit sharing between the investor and the entrepreneur who contributes skill, time, or goodwill. While the financial institution provides the necessary capital (rabb-ul-mal), the entrepreneur (mudarib) provides the operational capabilities. In the event of a loss, the financial institution loses its capital and the entrepreneur loses his or her invested labor and other intangible contributions. ${ }^{65}$ The salvage value belongs to the entrepreneur based on the Shari'ah dictate that the rabb-ul-mal should absorb all losses. Under this arrangement, money contributed by the capital provider (rabb-ul-mal) is invested by the entrepreneur (mudarib) in the business and is used to acquire "assets" (interpreted very broadly in this context so that no tangible asset is required) with the goal of profit generation. ${ }^{66}$ The mudharabah agreement typically stipulates that the mudharabah will generate profits periodically for set periods at a preagreed scheduled rate. All profit generated by the business is distributed between the rabb-ul-mal and the mudarib as previously agreed. Similar to the ijarah model, the agreements provide mechanisms for repayment of the original investment amount and for termination (on expiry, or earlier default).

\section{Musharaka ("Partnership with Profit/Loss Sharing")}

Musharaka is literally translated as "sharing." 67 Musharaka is a partnership in which both the customer and financial institution provide capital

Finance." Journal of Islamic Banking of Finance. Retrieved from https://ssrn.com/ abstract $=1930173$.

${ }^{65}$ Shaikh, Salman Ahmed. 2011. "A Critical Analysis of Mudarabah \& A New Approach to Equity Financing in Islamic Finance." Journal of Islamic Banking \& Finance. Retrieved from https://ssrn.com/abstract=1930173; Bacha, Obiyathulla I. 1997. "Adapting Mudarabah Financing to Contemporary Realities: A Proposed Financing Structure." INCEIF the Global University in Islamic Finance, https://mpra.ub.uni-muenchen.de/ 12732/1/MPRA_paper_12732.pdf.

66 Ibid.

${ }^{67}$ Musharakah Investopedia, https://www.investopedia.com/terms/m/musharakah.asp; Hussain, Mumtaz, Shahmoradi, Asghar, and Turk, Rima. 2015. "An Overview of Islamic Finance," IMF Working Paper, https://www.imf.org/external/pubs/ft/wp/ 2015/wp15120.pdf; El-Gamal, Mahmoud A. 2006. Islamic Finance: Law, Economics and Practice. Cambridge: Cambridge University Press; Rammal, Hussain Gulzar. 2004. Financing Through Musharaka: Principles and Application. Business Quest. Retrieved from https://ssrn.com/abstract=1442430. 
and share profits and losses based on a contract between the two parties concluded before the transaction is finalized. It is among the more common methods utilized to engage in project finance, real-estate purchases, letters of credit, and other investment projects. ${ }^{68}$ Another form of musharakah that has surfaced relatively recently is the "diminishing musharakah." According to this concept, an investor and customer or partner will participate either in the joint ownership of property or equipment, or in a joint commercial enterprise. Under the diminishing musharakah model, the share or interest of the investor will be paid off periodically along with the agreed profit. The investor's share or interest will therefore decrease and will eventually be paid off fully leaving the customer or partner the sole owner of the property, or the commercial enterprise, as the case may be.

A contract of mudharabah normally presumes that the mudarib (entrepreneur) has not invested capital to the mudharabah. The mudarib is responsible for the management only, while all the investment comes from rabb-ul-mal. Conversely, the musharaka is the preferred vehicle when the mudarib also wishes to invest capital into the business of mudharabah. In such cases, musharakah and mudharabah are combined together. This is typically how it is done in the real estate market.

\section{Istisna (“Agreement for Future Delivery")}

Istisna involves a funding party agreeing to produce, procure, manufacture, or construct and deliver a commodity or an asset at a predetermined future time at an agreed price to another party. ${ }^{69}$ The asset or commodity is sold for an amount equivalent to the aggregate of all phased payments made plus a profit margin. This vehicle is often used in project or real estate development financing to facilitate the advance of monies during the construction phase. In such circumstances, to facilitate a long-term

${ }^{68}$ Qadri, Shahzad. 2007. "Islamic Banking-An Introduction." Business Law Today $17(6), 59$.

Rammal, Hussain Gulzar. 2004. "Financing Through Musharaka: Principles and Application." Business Quest. Retrieved from https://ssrn.com/abstract=1442430.

${ }^{69}$ Hussain, Mumtaz, Shahmoradi, Asghar, and Turk, Rima. 2015. "An Overview of Islamic Finance," IMF Working Paper, https://www.imf.org/external/pubs/ft/wp/ 2015/wp15120.pdf; El-Gamal, Mahmoud A. 2006. Islamic Finance: Law, Economics and Practice. Cambridge: Cambridge University Press. 
financing arrangement, it is very often paired with an ijarah. On completion of the underlying asset, the istisna will be replaced by an ijarah over the completed asset.

\section{Takaful ("Mutual Benefit Society")}

Takaful, which is often translated as Islamic insurance, is essentially a mutual benefit society or co-operative system that aims to serve as a safety net for members in case of loss. ${ }^{70}$ It serves as an alternative to conventional insurance products that are seen as violating Islamic restrictions. Takaful policyholders make contributions to a mutual investment pool and agree to guarantee each other. ${ }^{71}$ Contributions are based on the type of coverage policyholders require and their personal circumstances. Similar to conventional insurance, a takaful contract specifies the nature of the risk and time period of coverage. ${ }^{72}$

\section{Sukuk (“Investment Certificate")}

Sukuk, commonly referred to as Islamic bonds, is more accurately translated as "Islamic investment certificates." understood as a contractual debt obligation, and the bond issuer is obligated to pay the bondholder both the principal as well as the interest at agreed-upon intervals. ${ }^{74}$ The primary difference between sukuk and a traditional bond is that sukuk is technically not debt and does not pay the security holder interest. ${ }^{75}$ Instead, sukuk holders become shareholders,

${ }^{70}$ For an explanation of takaful, see https://www.lexisnexis.com/uk/lexispsl/ bankingandfinance/document/391289/5BNP-XNT1-F185-X3CF-00000-00/Takaful_ overview.

71 Ibid.

72 Ibid.

${ }^{73}$ Thomas, Abdulkader, Cox, Stella, and Kraty, Bryan. 2005. Structuring Islamic Finance Transactions. Linnius; Box, Tamara and Asaria, Mohammed. 2005. "Islamic Finance Market Turns to Securitization." International Financial Law Review 24, 21.

${ }^{74}$ Koch, Michael. "Sukuk vs Conventional Bonds: A Study into the Performance of Islamic Bonds," https://pdfs.semanticscholar.org/e830/ 9e00e7de945a3e6lae4447208ee7a02e3b0f.pdf.

75 Abdel-Khaleq, Ayman and Richardson, Christopher. 2007. "New Horizons for Islamic Securities: Emerging Trends in Sukuk Offerings." Chicago Journal of International Law 7(2), 409-413. 
Table 7.1 Summary of key Islamic finance instruments

\begin{tabular}{ll}
\hline Arabic name of the financial instrument & Summary \\
\hline Murabahah & $\begin{array}{l}\text { Cost plus mark up/rent to own type of } \\
\text { arrangement }\end{array}$ \\
Ijarah & $\begin{array}{l}\text { Financial lease } \\
\text { Profit/loss sharing contract }\end{array}$ \\
Mudharabah & $\begin{array}{l}\text { Partnership with profit/loss sharing } \\
\text { Agreement to deliver a product or service } \\
\text { Istisna }\end{array}$ \\
at a time in future at an agreed price \\
Mukaful & $\begin{array}{l}\text { Mutual benefit society to pool and share } \\
\text { risks } \\
\text { Buknd like investment certificate that } \\
\text { converts into equity }\end{array}$ \\
\hline
\end{tabular}

holding the assets that are then leased back to the original company for an asset-related return over a predetermined period of time based upon the profit from the underlying assets. ${ }^{76}$

Each of these products/structures have numerous variations and iterations. There are many other products and instruments but the foregoing provides a good overview of the field and should give one a sense of how Islamic finance works. Table 7.1 provides a summary. The overview in this Part should also help shed some light on the potential for differences of opinion on the Shariah-compliance of the different products and vehicles. It also reveals the potential for confusion, misunderstanding, and even obfuscation and deception by unscrupulous actors who may wish to exploit religious sentiments. The next Part touches upon challenges, especially consumer protection concerns, that evolve from the status quo.

\section{Practical Issues in Implementing Islamic Finance}

While, at least theoretically, Islamic finance has much to offer with regard to economic and social justice, financial management, and ethics, the Islamic finance industry of today faces significant challenges, especially outside the Muslim world. Some of these issues are germane in Muslim states, too, but they are more pronounced or unique to jurisdictions that do not have an overarching Islamic judicial or regulatory body.

${ }^{76}$ Ibid. at 424 . 
These challenges include the following: (1) lack of knowledge and sophistication on the part of Muslim consumers and the non-existence of uniform standards; (2) shortage of experts with an understanding of Islamic rules, finance, law, and their interactions; (3) lack of sophistication, professionalism, and the resulting lack of credibility; (4) legal impediments, regulatory confusion, and lack of oversight; and (5) politics and public opinion. A few of these issues are highlighted below to provide an overview.

\section{LACK of KNowledge on the Part of Muslim Consumers and THE Non-EXISTENCE OF UNIFORM STANDARDS}

Far too many consumers lack basic knowledge about finance and financial risk and may make unwise financial decisions. They may also be easily duped by fraudsters and high-powered salespeople. This is the main reason that governments often have extensive rules and regulations when it comes to investments and financial schemes. This is true for all money matters, but as the foregoing discussion on Islamic finance illustrates, the situation can be even more complex when there is a marriage between finance and faith. ${ }^{77}$

Mahmoud Amin El-Gamal, a leading critic of the Islamic finance industry, argues that the industry is selling overpriced products to the religiously naive. He claims that sophisticated investors and the ultraorthodox religious players will see through what is being done in the name of Islamic finance, but he notes, "So you're left with the gullible who don't really understand the structure." 78 This is all the more dangerous when the faith is blind as is the case too many times when religious followers put their trust in pious and charismatic individuals or groups who use religion to advance their agendas including financial ones. ${ }^{79}$

77 "A Study of Retail Islamic Banking: The Relationship between Customer Knowledge and Service Quality," Khairul Firdaus Adrutdin\#1, Azlan Ali*2, Jimisiah Jaafar\#3, Sallaudin Hassan\#4 Nur Syafiqah A. Rahim\#5 http://ojs.excelingtech.co.uk/index.php/IJSCM/ article/view/1194.

${ }^{78}$ Marais, Richard. 2007. "Don't Call It Interest." Forbes, https://www.forbes.com/ forbes/2007/0723/122.html\#242132b74354.

${ }^{79}$ Here is an example of an article in a Muslim publication which essentially regurgitates what ijara, an Islamic finance company, says they 
Professor El-Gamal may be giving the ultraorthodox Muslims too much credit, because from my experience working with Islamic finance products, most Muslims, even the ultraorthodox, have a very limited or cursory understanding of Islamic finance in practice. The key questions are: (1) how do we get religious consumers to be more inquisitive, and (2) how do we get them to do more due diligence: This is particularly important given that consumer protection legislation in this context is virtually non-existent or deficient. The problem is heightened in nonMuslim jurisdictions because of a lack of awareness as to what is being done in the name of Islamic finance and the reluctance on the part of governments to intervene in a community's internal religious questions. Muslim jurisdictions are not immune either. Many of them are relatively unsophisticated in terms of consumer protection and lack the ability to effectively dictate what is or is not Shariah-compliant, because that is the realm of the religious establishment (many of whom are independent and/or unregulated by the state) for the most part.

Those who actually study Islamic finance will quickly realize that one of the central and highly debatable questions in Islamic finance is whether Islamic financial institutions actually avoid interest-based instruments, or simply reframe or relabel them in order to "comply" with Islamic law. 80 In Partnership, Equity-Financing and Islamic Finance: Whither Profit-Loss Sharing? Mohammad Omar Farooq argues that in order to attempt to avoid interest, Islamic finance has developed "an impressive array" of transactional modes that claim to be based on profit-loss-sharing (PLS). ${ }^{81}$ However, while the Islamic finance literature "continues to emphasize PLS as the main modes, in practice Islamic financial institutions (IFIs)

are doing: https://muslimlink.ca/islamic-finance/ijara-cdc-islamic-halal-mortgage-homefinancing-canada-how-does-it-work. At the bottom it indicates that it is a paid advertisement but most readers will not even get to that part. In practice, the structure through ijara is not different from a conventional loan with the caveats as noted below in the discussion in 2 below on UM Financial.

${ }^{80}$ Farooq, Mohammad Omar. 2007. "Stipulation of Excess in Understanding and Misunderstanding Riba: The Al-Jassas Link.” Arab Law Quarterly 21(4), 285-316.

El-Gamal, Mahmoud A. 2003. "Interest' and the Paradox of Contemporary Islamic Law and Finance." Fordham International Law Journal 27(1), Article 6, https://pdfs. semanticscholar.org/8cb7/0cc8baaf9l lad52f932205al722f76e3f049.pdf.

${ }^{81}$ Farooq, Mohammad Omar. 2007. "Partnership, Equity-Financing and Islamic Finance: Whither Profit-Loss Sharing." Review of Islamic Economics 11, 67 at 67-68. 
have deliberately and systematically avoided them." 82 Farooq goes on to argue that partnership modes of business organization, such as PLS, are inherently flawed, and that it is thus economically rational for Islamic financial institutions to use debt-like instruments while claiming compliance with Islamic law under the guise of PLS-like equity-based systems. ${ }^{83}$ Meanwhile, in practice, instead of PLS systems, Islamic finance has turned toward the murabahah, a model that often carries no risk for the Islamic finance institution, despite risk-sharing being one of the key conceptual components of Islamic finance. ${ }^{84}$ The mark-up model of the murabahah leaves all the risk on the buyer, except in the case of death or default, similar to conventional finance. ${ }^{85}$ While "Islamically there is nothing wrong with murabahah," there is also "nothing especially Islamic about it, either ... Banking primarily based on this type of transactions robs IFIs of distinctively Islamic characteristics." 86 Murabahah is ultimately not as Shari'ah-compliant as is generally claimed, and it is criticized by many scholars as well as some Islamic Financial institutions. ${ }^{87}$ This leads to a "basic contradiction." where the PLS models continue to dominate the literature; yet, in practice, IFIs continue to use murabahah and other modes that are functionally non-PLS and similar to conventional financial instruments. ${ }^{88}$ While IFIs "proclaim that the conventional financing based on interest is unjust since there is no fair sharing of profit-loss and risk," they themselves "do not utilize PLS modes substantively in their portfolios." 89 Farooq goes so far as to suggest that IFIs "make up ruses" to "manufacture products and services that are only legally Islamic,"

${ }^{82}$ Ibid. at 68; Dar, Humayon A. and Presley, John R. 2000. "Lack of Profit Loss Sharing in Islamic Banking: Management and Control Imbalances." International Journal of Islamic Financial Services 2(2), 3-18.

${ }^{83}$ Ibid. Warde, Ibrahim. 1999. "The Revitalization of Islamic Profit-and-Loss Sharing." Proceedings of the Third Harvard University Forum on Islamic Finance: Local Challenges, Global Opportunities. Cambridge, MA: Center for Middle Eastern Studies, Harvard University. 199-211, http://ifpprogram.com/login/view_pdf/?file=The\%20Revitalization\% 20of\%20Islamic\%20Profit-and-loss\%20Sharing.pdf\&type=Project_Publication.

${ }^{84}$ Ibid. at 70 .

85 Ibid. at 71 .

${ }^{86}$ Ibid. at 72 .

${ }^{87}$ Ibid. at 73 .

88 Ibid. at 74 .

${ }^{89}$ Ibid. at 85 . 
but have little difference in substance from conventional financial instruments. ${ }^{90}$ Farooq is not the only one or the first to make such claims. ${ }^{91}$

This gap between the theoretical discourse and the practice of IFIs may be due to an exaggeration of the "usefulness" of PLS models. 92 This exaggeration, in turn, may stem from a second fundamental issue within Islamic finance: the definition of riba. Specifically, the notion that riba, which is prohibited in Islam, is broadly equivalent to interest. While the traditional understanding of Muslims is that riba is equivalent to any interest, some scholars, such as Farooq, El-Gamal, Kuran, Rauf, and others argue that it only means "usury would be prohibited" but that "interest in all its forms as it exists in modern economy and finance can't be necessarily categorized as prohibited."93 While the Quran does not explicitly define riba, the common understanding is that the traditional definition is arrived at via six hadiths. In an analysis of these hadiths, Farooq finds that it is a "daunting task" to utilize these hadiths to broaden riba's scope "to contend that all forms of interest ... in a modern economy are prohibited." 94 Should the common understanding of riba be modified to a more narrow understanding of interest, IFIs would have more flexibility in the types of financial instruments they could offer. Moreover, even if one is to accept the traditional view of riba, consumers should be aware that there are differences of opinion on this issue.

The differences in interpretation of riba are not only being advanced by "modernists" or "liberals." Even a group of conservative jurists passed

${ }^{90}$ Ibid. at 86.

91 El-Gamal, Mahmoud A. 2003. "'Interest' and the Paradox of Contemporary Islamic Law and Finance." Fordham International Law Journal 27(1), Article 6, https://pdfs. semanticscholar.org/8cb7/0cc8baaf9llad52f932205al722f76e3f049.pdf; Kuran, Timur. 2004. Islam and Mammon: The Economic Predicaments of Islamism. Princeton: Princeton University Press; Hamoudi, Haider Ala. 2006. "Muhammad's Social Justice or Muslim Cant?: Langdellianism and the Failures of Islamic Finance." Cornell International Law Journal 40(1), Columbia Public Law Research Paper No. 06-116.

92 Dar, Humayon A. and Presley, John R. 2000. "Lack of Profit Loss Sharing in Islamic Banking: Management and Control Imbalances." International Journal of Islamic Financial Services 2(2), 3-18.

${ }^{93}$ Farooq, Mohammad Omar. 2009. "Riba, Interest and six Hadiths: Do We Have a Definition or a Conundrum?” Review of Islamic Economics 13(1), 105, 107.

Azhar, Rauf. November 15, 2009. Economies of an Islamic Economy, Themes in Islamic Studies, Vol. 6, https://doi.org/10.1163/ej.9789004179370.i-470.

${ }^{94}$ Farooq, Mohammad Omar. 2009. "Riba, Interest and six Hadiths: Do We Have a Definition or a Conundrum?" Review of Islamic Economics 13(1), 138. 
a fatwa permitting interest-based transactions as a necessity in the West given the lack of viable alternatives and the importance of acquiring a residence as a foundation for economic empowerment. ${ }^{95}$ They did by inference add a few caveats, including the following: ( 1 ) there must be no viable and practical Islamic alternative available; $(2)$ the house to be purchased must be for the buyer and his household; (3) the buyer must not have another house; (4) the buyer must not have any surplus of assets that can help him buy a house by means other than mortgage, and (5) the buyer must be actively working for or seeking out Sharia'b-compliant options. ${ }^{96}$

Another issue is the lack of uniform standards within a regulatory framework, creating large differences in practices and variations in instruments that all pass as "Shari'ah-compliant." 97 What is and what is not Shari'ah-compliant differs widely depending on the school of jurisprudence and the geographic area-and even within these domains, because each scholar's opinion is considered valid by his or her respective followers. ${ }^{98}$ There is no official clergy or central religious authority (at least in the Sunni context) that can be called upon to give the final word on what is Islamic finance or even Islamic law.

95 European Council for Ifta' and Research and the Conference of the League of Shari'ah Scholars of North America, "Permissibility of Conventional Mortgage Under Necessity." Fourth Ordinary Session (October 27-31, 1999) Resolution 2/4, https://eshaykh. com/halal_haram/permissibility-of-conventional-mortgage-under-necessity/ and http:// www.islamicmortgages.co.uk/index.php?id=259.

${ }^{96}$ Ibid. For a rebuttal, see Salah al-Sawi. June 21, 2001. A Polite Reconsideration of the Fatwa Permitting Interest-Based Mortgages for Buying Homes in Western Societies, translated by Usama Hasan, https://unityl.files.wordpress.com/2009/06/analysis-of-fatwason-mortgages.pdf.

${ }^{97}$ Wafik, Grais and Pellegrini, Matteo. 2006. Corporate Governance and Shariah Compliance in Institutions Offering Islamic Financial Services. World Bank Policy Research Working Paper No. 4054; Stubing, Darren. 2015. "Islamic Finance Held Back by Lack of Supervision, Liquidity." Global Finance, https://www.gfmag.com/magazine/may-2015/ lack-supervision-liquidity-holding-back-islamic-finance.

98 Pock, Alexander. 2007. Strategic Management in Islamic Finance. Berlin: Springer Science \& Business Media; Farook, Sayd Zubair and Farooq, Mohammad Omar. 2013. "Shariah Governance, Expertise and Profession: Educational Challenges in Islamic Finance." ISRA International Journal of Islamic Finance 5(1), 137-160; Box, Tamara and Asaria, Mohammed. 2005. "Islamic Finance Market Turns to Securitization." International Financial Law Review 24, 21. 
Different countries and different sects-and even schools of Islamic thought within those countries and sects-each have their own interpretation of religious as well as financial teachings of Islam. Contrary to popular perception, Islamic law is not monolithic. Rather, it is pluralistic and dynamic and, therefore, allows for flexibility to meet the demands of the changing social and economic circumstances, but it also creates obvious obstacles from a legal/regulatory and practical perspective. In the absence of a supreme authority (e.g., the highest court in jurisdiction for instance) with the power to rule on whether something is ultimately Shari'ah-compliant, the rules may be unpredictable and susceptible to a multitude of interpretations that result in "fatwa shopping." Interestingly, some scholars and critics have highlighted this practice, whereby Islamic finance bodies search out "Islamic" legal opinions to justify or rationalize what they want to do rather than seeking out the most reliable or "authentic" rulings in line with the spirit and letter of Islam. 99 In fact, studies have demonstrated that some Islamic finance professionals search for favorable scholars for quick recognition of products ${ }^{100}$ thereby giving an Islamic identity to products that are de facto conventional in nature. ${ }^{101}$

Education and reflection are critically important but highly unlikely to bear any immediate fruit because of the complexity of the field and the belief among many Muslims that they simply need to have good intentions and should leave the mechanics to "scholars." The fact that unscrupulous actors may take advantage of them is brushed off: "My intentions are good, if they want to dupe me then they will face God on the day of judgement." 102 Although an understandable theological position, this fatalistic view is fertile ground for exploitation.

${ }^{99}$ Oseni, Umar A., Ahmad, Abu Umar Faruq, and Hassan, M. Kabir. 2016. "The Legal Implications of 'Fatwā Shopping' in the Islamic Finance Industry." Arab Law Quarterly 30(2), 102-137.

${ }^{100}$ Hassan, M.K. and Dicle, M.F. 2007. "Basel II and Corporate Governance in Islamic Banks." in S.N. Ali (ed.), Integrating Islamic Finance into the Mainstream: Regulation, Standardization and Transparency. Cambridge, MA: Islamic Finance Project, Harvard Law School, 2007, 31-50.

${ }^{101}$ Khan, F. 2010. How “'Islamic' Is Islamic Banking?” Journal of Economic Behavior \& Organization 76(3), 818.

102 This is a typical conversation with clients when reviewing the obfuscation used by some Islamic finance entities. 


\section{Shortage of Experts with Simultaneous Understanding of Islamic Rules, Finance and Law}

The dearth of competent specialists trained in the field is a widely highlighted global problem in Islamic finance. ${ }^{103}$ Many have argued that there is a lack of human capital with Islamic finance know-how. ${ }^{104}$ I suspect the problem is not a shortage of Islamic scholars with know-how about Islamic finance, because this is not necessarily accurate. ${ }^{105}$ As Zulkifli Hasan notes, there are plenty of scholars with Islamic finance knowledge, but institutions stick with a known group for credibility and business reasons. I would also add that some are relied on because companies get what they want from these Shari'ah scholars who are paid handsomely and some of whom sit on dozens of boards. ${ }^{106}$ Sometimes the problem is exacerbated even when people have Islamic finance training or knowledge, because they do not appreciate or understand the whole picture. This results in approval of documents, instruments, or structures that are no different from conventional finance options, and sometimes it even results in these scholars or specialists being used to market exploitative or egregiously non-Shariah-compliant products and services. Scholars or specialists who lack a more holistic understanding or who fail to appreciate the technical and complex interplay often involved in such documents or transactions are sometimes inadvertently duped by shady businesspeople or occasionally even well-meaning proponents of Islamic finance. ${ }^{107}$

103 Abbas, Mohammed. February 2, 2008. "Shortage of Scholars Troubles Islamic Banking." The New York Times, https://www.nytimes.com/2008/01/22/business / worldbusiness/22iht-bank.4.9412578.html; Barreh, Ismail. "Scholar Shortage Threatens Islamic financing industry." MuslimLink, https://muslimlink.ca/islamic-finance/scholarshortage-threatens-islamic-financing-industry.

104 Ibid.

${ }^{105}$ Hasan, Zulkifli. 2012. "Demystifying the Myth of Shortage of Shari'ah Scholars," https://zulkiflihasan.wordpress.com/2012/03/02/demystifying-the-myth-ofshortage-of-shariah-scholars-2/.

${ }^{106}$ Inevitably when small cliques dominate and monopolize an industry and money is involved, it is only a matter of time before problems start. See Barreh, Ismail. "Scholar Shortage Threatens Islamic Financing Industry." MuslimLink, https://muslimlink.ca/ islamic-finance/scholar-shortage-threatens-islamic-financing-industry.

${ }^{107} \mathrm{Ha}$, Tu Thanh. 2014. "RCMP Charge Missing Toronto Financier with \$4.3Million Mortgage Fraud." The Globe and Mail, https://www.theglobeandmail.com/ news/national/rcmp-charge-missing-toronto-financier-with-43-million-mortgage-fraud/ article16972349/; Seputis, Jasmine. 2018. "2 Men Defrauded Shariah-Compliant 
In the Canadian context, I have witnessed many schemes being approved as Shari'ah-compliant, such as the "musharakah" agreement used by UM Financial mentioned earlier, when financial institutions are doing nothing more than relabeling, playing with terminology, and drafting parallel documents. In such contracts, even though terminology from Islamic finance is widely used, the key thing is that (1) the borrowers may not fully realize that they are effectively paying "interest" on the loan, because it might be labeled otherwise, and (2) there is a range of opinion among Islamic finance scholars about what products/services are consistent with Islamic principles.

With such contracts, an Islamic scholar who only understood the rules of theoretical Islamic finance would not be able to understand these transactions. The scholar must understand the theory of Islamic finance, the practical details, and the conventional loan procedures, as well as the legal and real estate practice and procedures. Such people are few and far between. ${ }^{108}$

\section{LACK OF PROFESSIONALISM AND the Resulting Lack of CRedibility}

Though there are some studies focusing on customer satisfaction with Islamic finance companies in the Muslim world, there appear to be no such studies in the context of Islamic finance companies in the West. Anecdotally, the customer service landscape in the western Islamic finance market is far from glowing. As small-time operators or community-based groups, customer service is usually not their forte. The disgruntled client, whose story I shared at the start of this chapter, only went to the Law Society because he thought I was part of UM. Moreover, he had been

Mortgage-Holders of Millions of Dollars, Crown Tells Trial." CBC News, https://www. cbc.ca/news/canada/toronto/2-men-defrauded-shariah-compliant-mortgage-holdersof-millions-of-dollars-crown-tells-trial-1.4867083; Sweeney, Annie. March 28, 2011. "Guilty Plea in Fraud Scheme That Targeted Muslim community." The Chicago Tribune, https://www.chicagotribune.com/news/ct-xpm-2011-03-28-ct-met-muslim-fraud-guilty20110328 -story.html.

${ }^{108}$ I have carried out what I call the "coke" v. "pepsi" equivalent test ("conventional mortgage" v. "Islamic Finance" test) on some Islamic scholars who have given opinions on Islamic finance products, and they were not able to differentiate between the two. In fact, in at least two cases, the scholars chose the "conventional" as more "fair," "just," "reasonable," "more affordable," and "less exploitative." 
unable to get a satisfactory response from UM on his questions or complaints even after months of trying. He found it difficult to reach UM and when he did, they were unresponsive. UM is not alone in lacking professionalism and sophistication. As small, independent, private, and non-mainstream, Islamic finance entities cannot be expected to meet the service levels people have grown to expect from conventional financial institutions. Much of this has to do with limitations in terms of financial resources, human resources, and, to some extent, even cultural factors. This of course creates a vicious circle that results in even poorer service over time and lowered expectations.

Given that the competitive advantage of Islamic banking lies in the fact that the products and services offered are indeed Shariab-compliant, some of the practices described earlier in this chapter diminish public faith in Islamic finance companies. While Islamic financial institutions usually have internal boards to verify that their products comply with Islamic principles, this approach "gave rise to conflicting rulings and products of Islamic banking that confused clients and investors," notes a 2017 statement by the Accounting and Auditing Organisation for Islamic Financial Institutions (AAOIFI). "If the confusion persists, the credibility of Islamic banking and finance as a whole may be jeopardized."109 Consumer confidence is also impacted significantly when there are damaging reports, such as UM going into receivership or its principals being charged with criminal fraud.

The situation will not improve until Islamic financial institutions take concrete steps to implement standards. The Islamic banking world has increased its efforts to standardize regulation and supervision. The Islamic Development Bank is playing a key role in developing internationally acceptable standards and procedures for strengthening the sector's architecture in different countries. Moreover, international organizations, such as the AAOIFI, the Islamic Finance Service Board (IFSB), the International Islamic Financial Market, the Liquidity Management Center, and the International Islamic Rating Agency, are working to set Shari'ahcompliant standards and harmonize them across countries. ${ }^{110}$ However, despite the efforts of these international organizations to place the Islamic

${ }^{109}$ Domat, Chloe. 2018. "Towards Standards in Islamic Finance." Global Finance, https://www.gfmag.com/magazine/march-2018/toward-global-islamic-finance-standard.

${ }^{110}$ El Qorchi, Mohammed. 2005. "Islamic Finance Gears Up." Finance and Development 42(4), 46. 
finance industry on a sound footing, "there are no generally acceptable guidelines or standards on accounting, auditing, legal, governance, and Shari'ah issues as yet." 111 Moreover, the problem is even worse in nonMuslim jurisdictions for obvious reasons.

Unsurprisingly the fragmented regulatory structure of Islamic finance has attracted criticism. Academics and practitioners alike have argued that the lack of standardization of Shari'ah rules creates problems of consistency, predictability, and fairness. Several commentators have argued that such a fragmented regulatory structure hinders the success and advancement of Islamic finance, and it also reinforces consumer protection concerns as well as consumer confidence. ${ }^{112}$

In addition to issues of expertise, the absence of holistic and interdisciplinary knowledge, the lack of standardization as well as the potential conflict of certifiers serving as regulators, and of course "fatwa shopping" are problematic for the practice of Islamic finance. This is all the more dangerous given that some of these same scholars are also serving as auditors, standard setters, legislators, and regulators.

\section{LEGAL IMPEDIMENTS, REgULATORY CONFUSION AND LACK OF OVERSIGHT}

There are currently two predominant types of regulatory regimes governing Shari'ah-compliant institutions in Muslim countries. One approach

${ }^{111}$ Oseni, Umar A., Ahmad, Abu Umar Faruq, and Hassan, M. Kabir. 2016. "The Legal Implications of 'Fatwā Shopping' in the Islamic Finance Industry." Arab Law Quarterly 30(2) 107-137 at 108 .

${ }^{112}$ See Balz, Kilian, 2007. "Islamic Finance for European Muslims: The Diversity Management of Shari'ah-Compliant Transactions." Chicago Journal of International Law 7(2), 551 .

Intervention by a centralized regulator is essential in a competitive environment to induce Islamic banks to formulate Shariah-compliant financial products. The regulator fixes a structural threshold below which any financial product like Murabaha becomes non-Shariah-compliant. The actual structure of the financial product developed by an Islamic bank is unobserved by the regulator. It only becomes known in the event of an audit conducted by the regulator (the article below by Azmat et al....).

Azmat, Saad, Azad, A.S.M. Sohel, Ghaffar, Hamza, and Bhatti, Ishaq. 2015. "Why Interest Free Islamic Banking Is Not Free from Interest?” https://www.deakin.edu.au/_ _data/assets/pdf_file/0003/392295/islamic-banking-not-free-from-interest-Azmat-AzadGhaffar-and-Bhatti.pdf; Wilson, Rodney. 2004. Capital Flight Through Islamic Managed Funds. Edinburgh: Edinburgh University Press. 
places Islamic institutions under the central bank, but in a regime entirely different from that of the conventional banks. ${ }^{113}$ A second practice recognizes the uniqueness of the Islamic institutions but places them under the same supervision and regulatory regime that governs conventional banks, with slight modifications and special guidelines. ${ }^{114}$ In Canada and the United States, similar to most non-Muslim countries, the industry is governed by a regulatory and supervisory framework developed for conventional finance with no consideration for the uniqueness of Islamic financial institutions. ${ }^{115}$ Therefore, the regulatory regime does not take into account the special nature of Islamic finance, which creates several compliance issues for Islamic financial institutions. ${ }^{116}$

One of the biggest challenges to the development of Islamic finance in Canada and the United States is the difficulty for new institutions getting through the application process to receive a banking license. ${ }^{117}$ Even if an Islamic bank was to get licensed, the restrictions on real estate ownership would obviously be an issue for Islamic-financial institutions, especially if the Islamic finance company wishes to structure "pure" Islamic models. ${ }^{118}$ According to the majority opinion, the Islamic institution must hold legal title until the process is complete. Banking laws may also restrict non-real estate investments, limiting them to fixed-income and interestbearing securities, which are deemed prohibited by most proponents of Islamic finance.

113 (Example, Yemen and Malayisa). El Qorchi, Mohammed. 2005. "Islamic Finance Gears Up." Finance and Development 42(4), 46.

114 (Example, Bahrain and Qatar). Ibid.

115 Islamic Finance: Opportunities, Challenges, and Policy Options, International Monetary Fund.

${ }^{116}$ Canada Islamic Finance Outlook 2016. Toronto Financial Service Alliance, IFSB Working Paper on Financial Consumer Protection In Islamic Finance.

Nienhaus, Volker. 2015. "IFSB Working Paper on Financial Consumer Protection in Islamic Finance. IFSB Working Paper Series.” Islamic Financial Services Board, https:// www.ifsb.org/docs/WP-03-Consumer\%20Protection(final).pdf.

117 http://dtpr.lib.athabascau.ca/action/download.php?filename=mba-11/open/ edwardlauraProject.pdf.

118 In order to structure a house purchase transaction, for instance, the title will have to remain in the name of the Islamic finance company (either solely or jointly) until the transaction is completed. 
Taxes pose another challenge. ${ }^{119}$ Sharia-compliant products generally do not fit within the definitions that currently govern the conventional financial products, despite their similar economic features. Both tax authorities and taxpayers lack knowledge of the specific features of Islamic products. Considering the technical, interpretive, and policyrelated issues, obtaining rulings from the relevant authorities can be quite lengthy and costly. ${ }^{120}$ One glaring tax issue in the context of real property is land transfer. ${ }^{121}$ Institutions that purchase a home and then resell it to the final purchaser may face, in addition to other issues, double or even triple transfer tax costs depending on the transaction and the jurisdiction. Some jurisdictions may have worked around it, but it remains a problem in other jurisdictions. ${ }^{122}$ For instance, in Ontario where the Islamic Cooperative Housing Corporation and Ansar Co-operative Housing Corporation (hereinafter collectively the Co-op) purchase homes for people and keep the title until the Co-op's contribution is paid off, the Ministry of Finance initially did not concern itself with collecting taxes on subsequent transfers. After years of not making it an issue, the Ministry then started reassessing homeowners thousands of dollars in taxes. They took the position that land transfer taxes were payable when the house was initially purchased and again when title is transferred to the actual homeowner. Following meetings with Ministry officials where they were briefed on the structure of the home purchase model, the Ministry tentatively suspended this practice, but there is still no definitive ruling on

119 Canada Islamic Finance Outlook 2016. Toronto Financial Service Alliance.

${ }^{120}$ For details, see Islamic Finance Working Group. 2010. Toronto Financial Service Alliance. Retrieved from http://www.tfsa.ca/resources/pdf/TFSA_IFWG_Prelim_ Report_May14_2010_final_2.pdf.

${ }^{121}$ Land Transfer Tax or Stand Duty Land Tax or Real Estate Transfer Tax are taxes payable on transfers of real properties. There are some exemptions. See, for example, https://www.fin.gov.on.ca/en/tax/ltt/; https://www.gov.uk/stamp-dutyland-tax; https://www.nar.realtor/smart_growth.nsf/docfiles/transfertaxrates(8-05).pdf/ \$file/transfertaxrates(8-05).pdf.

122 Islamic finance/alternative finance arrangements and tax-overview, https://www. lexisnexis.com/uk/lexispsl/tax/document/393773/5BR0-C761-F18C-V2DB-0000000/Islamic_finance_alternative_finance_arrangements_and_tax_overview. 
this despite waiting more than ten years. ${ }^{123}$ This obviously creates uncertainty for the thousands of homeowners who can be reassessed at any point within a certain limitation period.

Another potential issue that may arise is the loss of rebates or credits on property and other tax implications. ${ }^{124}$ The wide variety of the Islamic financial products may alone create the need for significant resources to approach the tax authorities. The interplay and interaction between federal and state/provincial laws, regulations, and policies may raise even more complexities for Islamic finance companies. ${ }^{125}$

Lastly, as touched upon earlier in this chapter, the non-existence of oversight or regulatory bodies in the Islamic context adds to the complexity. At least in Muslim countries some steps are being taken to address this issue. The Bahrain-based AAOIFI is working toward establishing worldwide norms and standards for Islamic finance and banking practices. The AAOIFI, with hundreds of member institutions across forty-five countries, has adopted guidelines to centralize these boards and introduce new standards. Its standards are already widely used within the Islamic finance industry, and are compulsory in some countries. ${ }^{126}$ The fact remains that there are no such standards or regulatory bodies that can oversee them in non-Muslim jurisdictions. This makes it difficult to engage with mainstream authorities in working around regulations, laws, policies, etc.

${ }^{123}$ I met with Ministry of Finance officials on behalf of the Islamic Co-operative Housing Corporation/Ansar Co-operative Housing Corporation.

${ }^{124}$ Some jurisdictions provide property tax relief for residential properties, and some jurisdictions provide relief or rebates from other types of taxes, both of which may not be smoothly accessed when transactions are structured in accordance with Islamic finance rules. I have seen issues with tax authorities that question why a corporation is applying for tax relief for a residential home or how a corporation can claim to reside in a residential property, etc. These issues come about because ownership rests with the institution and other structural factors.

125 See, for example, http://www.woodllp.com/Publications/Articles/pdf/Taxation_ of_Islamic_Finance_Part_l.pdf; https://www.mohammedamin.com/Islamic_finance/ Euromoney-chapter-tax-treatment-of-Islamic-finance.html.

${ }^{126}$ Domat, Chloe. 2018. "Towards Standards in Islamic Finance." Global Finance, https://www.gfmag.com/magazine/march-2018/toward-global-islamic-finance-standard. 


\section{Politics and Public Opinion}

A more recent obstacle, which became exceedingly pronounced in the wake of the tragic events of $9 / 11$, is the false association that Islamic finance is necessarily connected with terrorism, extremism, and even money laundering. ${ }^{127}$ Some anti-Muslim activists have taken it upon themselves to raise the alarm about Islamic finance being a back door to introduce Shari'ah into Western lands. ${ }^{128}$ They are playing on the fear of Shari'ah as it exists in the minds of far too many in this day and age. ${ }^{129}$ This is no exaggeration. Anti-Muslim activists are campaigning and lobbying governments to oppose any accommodation in the Islamic finance context. During my meetings with the Ministry officials on the issue of double land transfer tax on a behalf of my clients, the extent of the lobbying became clear to me. In fact, for more than twenty years the Ministry had no issue with how the transactions were structured, and they did not expect land transfer tax a second time when a property was transferred from the Islamic finance company to the homeowner. The Minister had accepted the following:

1. that the property was initially purchased on behalf of the homeowner;

2. that land transfer tax was paid when the property was acquired from the seller;

3. that the Islamic finance institution was simply holding title as security for the amount it had advanced toward the purchase; and

4. that the structure of the transaction was not to evade taxes but to comply with religious requirements.

The Ministry all of sudden changed its view and started assessing land transfer taxes on all transfers to owners. During the meeting it became

127 https://zulkiflihasan.wordpress.com/2009/12/30/another-sign-of-islamophobia/; https://www.aa.com.tr/en/turkey/islamophobia-prevents-islamic-finance-expansionmalaysian-scholar/219396.

128 https://www.theglobeandmail.com/news/national/banks-are-helping-sharia-makea-back-door-entrance/article1051161/.

129 https://www.nydailynews.com/opinion/silly-american-fear-sharia-law-article-1. 3229045; https://www.thestar.com/opinion/commentary/2017/02/20/factors-toconsider-about-sharia-law-and-ml 03.html. 
clear that it had been lobbied by "people from the community" who feared that allowing Islamic finance would legitimize Shariah and open the doors to all that it supposedly means. This has been a theme advanced by Islamophobes, including some self-proclaimed secular Muslims. I was even asked a hypothetical by one of the attendees: would Muslims who used conventional banks be labeled as apostates if Islamic institutions were available. My answer, of course, was that both systems coexist in Muslim countries and I have yet to hear of anyone being branded an apostate for choosing conventional banking. Islamophobia is alive and well in the Islamic finance context as well.

Contrary to some fear mongering, Islamic finance is not the lead chariot in "Islamization" and is not especially susceptible to money laundering or terrorist financing. ${ }^{130}$ Yes, it can be abused, just as conventional financing can. For the vast majority it is simply an exercise in attempting to integrate their faith into their financial dealings. Though theory and practice diverge in the attempt to implement faith, this should not detract from the idealism of those who seek to abide by it. It certainly should not be seen as part of a conspiracy to spread Shari'ah or fund terrorism.

\section{CONCLUSION}

Islamic finance, in theory, has much to offer to global finance, but its current practice falls far short of Islamic economic and financial ideals. As many scholars and practitioners have pointed out, Islamic finance as it exists in practice today for the most part is a financial system: "characterized by an incoherent web of rules, convenient and specific blindness respecting those rules in particular contexts, and deceptive and obfuscatory measures intended to lend the entire affair a patina of legitimacy as Islamic. Social justice and fairness are not significant components of the system."131 This unfortunate reality should not cloud the need for,

${ }^{130}$ Terrell, Ron. (2007). "Islamic Banking: Financing Terrorism or Meeting Economic Demand?" (thesis). Naval PostGraduate College, https://apps.dtic.mil/dtic/tr/ fulltext/u2/a475770.pdf; See also https://www.acamstoday.org/islamic-finance-moneylaundering-and-terrorist-financing/.

${ }^{131}$ Hamoudi, Haider Ala. 2006. "Muhammad's Social Justice or Muslim Cant?: Langdellianism and the Failures of Islamic Finance." Cornell International Law Journal 40(1), Columbia Public Law Research Paper No. 06-116. 
and promise of, Islamic finance. What many critics do not realize is that the instability of conventional, debt-based, finance has been criticized by many Western scholars who are quite innocent of Islamic finance or of the Shari'ah. Starting with Irving Fisher in the 1930s, many have noted how a profit-loss sharing system would produce a more stable economic system. Well-known economists, such as Willem H. Buiter, ${ }^{132}$ have argued that the world has too much leverage and too little equity, while the question posed by Luigi Zingales in his Presidential address to the American Finance Association was "Does Finance benefit Society."133 The alternative faith-based proposal of Islamic finance is to share both profits and losses. As Timur Kuran, an unsympathetic observer, notes in the context of Islamic finance in Egypt:

Having suggested that in its present form Islamic banking would not solve any of Egypt's pressing economic problems, let me acknowledge that Islamic banks might bring benefits by abiding by their stated mode of operation. The charters of Islamic banks instruct them to lend on the basis of "profit and loss sharing" rather than for a fixed return. ${ }^{134}$

The concept of profit/loss sharing has broad appeal, even outside of Islamic finance; Martin Weitzman ${ }^{135}$ of MIT, for example, has argued for a sharing economy.

The glaring defect of Islamic finance as it exists is that the practical implementation of profit/loss-sharing arrangements remains fairly limited. Furthermore, there seem to be no realistic prospects of a change toward equity instead of debt. Even though the returns to equity

132 Buiter, Willem H. and Rahbari, Ebrahim, 2015. "Why Economists (and Economies) Should Love Islamic Finance." Journal of King Abdulaziz University: Islamic Economics 28(1). Retrieved from https://ssrn.com/abstract=3065269.

133 Zingales, L. 2015. "Does Finance Benefit Society?” Journal of Finance 70(4), 13271363.

${ }^{134}$ Worstall, Tim. March 16, 2013. "There's Nothing Wrong With Islamic Finance as Long as It Really Is Islamic Finance." Forbes, https://www.forbes.com/sites/timworstall/ 2013/03/16/theres-nothing-wrong-with-islamic-finance-as-long-as-it-really-is-islamicfinance/\#53e598cb3e $2 b$.

${ }^{135}$ Weitzman M.L., Kruse D.L. 1990. "Profit Sharing and Productivity." In Blinder AS Paying for Productivity: A Look at the Evidence. Washington, DC: Brookings Institution, 95-142. 
(profit/loss-based) are clearly very much higher than that of bonds (interest based) in the long-run, Islamic finance has simply not risen to the challenge of realizing this long-run potential. This sloth is inexplicable in view of the Quranic warning that usury will bring war upon those who practice it:

O you who believe, fear Allah and give up what remains due to you of interest if you are indeed believers. And if you do not, then be warned of war (against you) by Allah and His Messenger, while if you repent you shall have your capital. Do not do wrong and you shall not be wronged.

(Quran 2:278-279)

If the Islamic finance industry and government regulators address the concerns and complaints made by a growing number of critics, including former champions ${ }^{136}$ of the industry, then there is still hope that the original ideals of Islam can provide a more equitable and stable economic system. In this case, faith has not sufficiently guided finance.

\section{BIBLIOGRAPHY}

Abbas, Mohammed. "Shortage of Scholars Troubles Islamic Banking." The New York Times, 2 February 2008. https://www.nytimes.com/2008/01/ 22/business/worldbusiness/22iht-bank.4.9412578.html.

Abdel-Khaleq, Ayman, and Christopher Richardson. "New Horizons for Islamic Securities: Emerging Trends in Sukuk Offerings." Chicago Journal of International Law 7, no. 2 (2007): 409-413.

136 Saleem, Muhammad. 2006. Islamic Banking-A $\$ 300$ Billion Deception: Observations and Arguments on Riba (Interest or Usury), Islamic Banking Practices, Venture Capital and Enlightenment. Bloomington: Xlibris Corporation.

I tell you, truthfully and without pretense, ... that we went beyond choosing the "bank" label [in "Islamic Banking"], to the point of adopting its central essence ... Consequently, we failed to give our financial institutions any characteristics beyond simple financial intermediation. This is accomplished through Islamic banks' favorite investment modes that are essentially a hybrid between loans and investment; which hybrid carries most of the characteristics of usurious loans....

Kamel, Saleh. 1996. (founder of Dallah al-Baraka group, acceptance speech for the Islamic Development Bank prize in Islamic Banking) quoted in El-Gamal, Mahmoud A. 2003. "Interest' and the Paradox of Contemporary Islamic Law and Finance," Fordham International Law Journal 27(1), Article 6, https://pdfs.semanticscholar.org/8cb7/ 0cc8baaf91 lad52f932205al722f76e3f049.pdf. 
Abdullah, Atikullah Hj. "The Elements of Qimar (Wagering) and Gharar (Uncertainty) in the Contract of Insurance Revisited," 2013. https://ibtra.com/ pdf/journal/v9_n2_article5.pdf.

Ahmad, Shaikh Mahmud. "Judaism and Interest." Islamic Studies 20, no. 1 (1981): 47-82.

Al-Hamdani, Khaled. al-Nizam al-Masrafi fi al-Dawlah al-Islamiyah (The Banking System in the Islamic State), 2000.

Alharbi, Ahmad. "Development of Islamic Finance in Europe and North America: Opportunities and Challenges." International Journal of Islamic Economics and Finance Studies 2, no. 3 (2016): 109-110.

Arberry, Arthur John. The Koran Interpreted: A Translation. New York: Simon and Schuster, 1996.

Archer, Simon, and Rifaat Abdel Karim. Islamic Finance: Growth and Innovation. London: Euromoney Books, 2002.

Ayub, Muhammad. Understanding Islamic Finance, 58. West Sussex: Wiley, 2007. Retrieved 30 August 2018.

Azhar, Rauf. Economies of an Islamic Economy, Themes in Islamic Studies, Vol. 6, 15 November 2009. https://doi.org/10.1163/ej.9789004179370.i-470.

Aziz, Zeti A. "Enhancing Interlinkages and Opportunities: The Role of Islamic Finance." Islamic Finance: Global Trends and Challenges 18 (2008): 5-7.

Azmat, Saad, A. S. M. Sohel Azad, Hamza Ghaffar, and Ishaq Bhatti. "Why Interest Free Islamic Banking Is Not Free from Interest?” 2015. https:// www.deakin.edu.au/_data/assets/pdf_file/0003/392295/islamic-bankingnot-free-from-interest-Azmat-Azad-Ghaffar-and-Bhatti.pdf.

Bacha, Obiyathulla I. "Adapting Mudarabah Financing to Contemporary Realities: A Proposed Financing Structure." INCEIF the Global University in Islamic Finance, 1997. https://mpra.ub.uni-muenchen.de/12732/1/ MPRA_paper_12732.pdf.

Balz, Kilian. "Islamic Finance for European Muslims: The Diversity Management of Shari'ah-Compliant Transactions." Chicago Journal of International Law 7, no. 2 (2007): 551.

Barreh, Ismail. "Scholar Shortage Threatens Islamic Financing Industry." MuslimLink, https://muslimlink.ca/islamic-finance/scholar-shortagethreatens-islamic-financing-industry.

Box, Tamara, and Mohammed Asaria. "Islamic Finance Market Turns to Securitization." International Financial Law Review 24 (2005): 21.

Buiter, Willem H., and Ebrahim Rahbari. "Why Economists (and Economies) Should Love Islamic Finance." Journal of King Abdulaziz University: Islamic Economics 28, no. I (2015). Retrieved from https://ssrn.com/abstract= 3065269.

Canada Islamic Finance Outlook 2016. Toronto Financial Service Alliance, IFSB Working Paper on Financial Consumer Protection In Islamic Finance. 
Chachi, Abdelkader. "Origin and Development of Commercial and Islamic Banking Operations." Journal of King Abdulaziz University: Islamic Economics 18, no. 2 (2005 A.D/1426 A.H): 3-25.

Dar, Humayon A., and John R. Presley. "Lack of Profit Loss Sharing in Islamic Banking: Management and Control Imbalances." International Journal of Islamic Financial Services 2, no. 2 (2000): 3-18.

di Mauro, Filippo, Pierluigi Caristi, Stéphane Couderc, Angela Di Maria, Lauren Ho, Baljeet Kaur Grewal, Sergio Masciantonio, Steven R. G. Ongena, Sajjad Zaheer. "Islamic Finance in Europe." ECB Occasional Paper No. 146. 15 April 2013. Retrieved from https://ssrn.com/abstract=2251204.

Domat, Chloe. "Towards Standards in Islamic Finance." Global Finance, 2018. https://www.gfmag.com/magazine/march-2018/toward-global-islamicfinance-standard.

El-Gamal, Mahmoud A. "'Interest' and the Paradox of Contemporary Islamic Law and Finance." Fordham International Law Journal 27, no. 1 (2003): Article 6. https://pdfs.semanticscholar.org/8cb7/ 0cc8baaf9l lad52f932205al722f76e3f049.pdf.

El-Gamal, Mahmoud A. Islamic Finance: Law, Economics and Practice. Cambridge: Cambridge University Press, 2006.

El-Ghattis, Nedal. "Islamic Banking's Role in Economic Development: Future Outlook." Retrieved from https://pdfs.semanticscholar.org/cfc6/ 6f09435a5445c2cadd2d18937823635c5d3d.pdf.

El Qorchi, Mohammed. "Islamic Finance Gears Up." Finance and Development 42 , no. 4 (2005): 46.

European Central Bank. "Islamic Finance in Europe," (Occasional Paper Series, No. 146, June 2013). Retrieved from https://www.ecb.europa.eu/pub/pdf/ scpops/ecbocpl46.pdf.

European Council for Ifta' and Research and the Conference of the League of Shari'ah Scholars of North America, "Permissibility of Conventional Mortgage Under Necessity." Fourth Ordinary Session (27-31 October 1999) Resolution 2/4-https://eshaykh.com/halal_haram/permissibility-of-conventionalmortgage-under-necessity/ and http://www.islamicmortgages.co.uk/index. php?id=259.

Fadel, Mohammad Riba. "Efficiency, and Prudential Regulation: Preliminary Thoughts." Wisconsin International Law Journal 25, no. 4 (Forthcoming): 656.

Farook, Sayd Zubair, and Mohammad Omar Farooq. "Shariah Governance, Expertise and Profession: Educational Challenges in Islamic Finance." ISRA International Journal of Islamic Finance 5, no. l (2013): 137-160.

Farooq, Mohammad Omar. "Stipulation of Excess in Understanding and Misunderstanding Riba: The Al-Jassas Link." Arab Law Quarterly 21, no. 4 (2007): 285-316. 
Farooq, Mohammad Omar. "Riba, Interest and Six Hadiths: Do We Have a Definition or a Conundrum?" Review of Islamic Economics 13, no. 1 (27 December 2009): 105-141.

Ferruelo, Elizabeth. "Why Socially Responsible Investing and Islamic Finance is on the Rise." Forbes, 2012. https://www.forbes.com/sites/ashoka/2012/ $11 / 01 /$ why-there-is-high-growth-potential-in-the-nexus-between-sociallyresponsible-investing-and-islamic-finance/\#5813dab0e3fl.

Ha, Tu Thanh. "RCMP Charge Missing Toronto Financier with \$4.3-Million Mortgage Fraud." The Globe and Mail, 2014. https://www.theglobeandmail. $\mathrm{com} /$ news/national/rcmp-charge-missing-toronto-financier-with-43-millionmortgage-fraud/articlel6972349/.

Hamoudi, Haider Ala. 2006. "Muhammad's Social Justice or Muslim Cant?: Langdellianism and the Failures of Islamic Finance." Cornell International Law Journal 40, no. 1 (2006). Columbia Public Law Research Paper No. 06-116.

Hanif, Muhammad. "Differences and Similarities in Islamic and Conventional Banking." International Journal of Business and Social Sciences 2, no. 2 (2014): 26.

Hasan, Zulkifli. "Demystifying the Myth of Shortage of Shari'ah Scholars," 2012. https://zulkiflihasan.wordpress.com/2012/03/02/demystifyingthe-myth-of-shortage-of-shariah-scholars- $2 /$.

Hassan, M. K. and M. F. Dicle. "Basel II and Corporate Governance in Islamic Banks." In Integrating Islamic Finance into the Mainstream: Regulation, Standardization and Transparency, edited by S. N. Ali, 31-50. Cambridge, MA: Islamic Finance Project, Harvard Law School, 2007.

Hayat, Usman. "Islamic Finance and Socially Responsible Investing." CFA Institute News, 2013. https://www.cfainstitute.org/-/media/documents/article/ cfa-magazine /2013/cfm-v24-n2-2.ashx.

Hussain, Mumtaz, Asghar Shahmoradi, and Rima Turk. "An Overview of Islamic Finance.” IMF Working Paper, 2015. https://www.imf.org/external/pubs/ $\mathrm{ft} / \mathrm{wp} / 2015 / \mathrm{wp} 15120 . \mathrm{pdf}$.

Iqbal, Zamir, and Abbas Mirakhor. An Introduction to Islamic Finance: Theory and Practice, 2nd ed. Asia: Wiley, 2011.

Islamic Finance Working Group. Toronto Financial Service Alliance, 2010. Retrieved from http://www.tfsa.ca/resources/pdf/TFSA_IFWG_Prelim_ Report_May14_2010_final_2.pdf.

Issawi, C. The Economic History of the Middle East 1800-1914. Chicago: University of Chicago Press, 1966.

Jamaldeen, Faleel. "Seven Prohibited Industries in Islamic Financial Investments." https://www.dummies.com/personal-finance/islamic-finance/sevenprohibited-industries-in-islamic-financial-investments $/$. 
Kamali, M. H. "Source, Nature and Objectives of Shari'ah." Islamic Quarterly 33 (1989): 211-233.

Karasik, Theodore, Frederic Wehrey, and Steven Strom. "Islamic Finance in a Global Context: Opportunities and Challenges." Chicago Journal of International Law 7, no. 2 (2006): 379.

Khan, F. How “'Islamic' Is Islamic Banking?” Journal of Economic Behavior \& Organization 76, no. 3 (2010): 818.

Khan, Sheema. "It's Time to Take Interest in Islamic Financing." The Globe and Mail, 7 April 2008. https://www.theglobeandmail.com/opinion/its-time-totake-interest-in-islamic-financing/article22501330/.

Koch, Michael. "Sukuk vs Conventional Bonds: A Study into the Performance of Islamic Bonds." https://pdfs.semanticscholar.org/e830/ 9e00e7de945a3e6lae4447208ee7a02e3b0f.pdf.

Kuran, Timur. Islam and Mammon: The Economic Predicaments of Islamism. Princeton: Princeton University Press, 2004.

Kutty, Faisal. "The Myth and Reality of 'Shari'a Courts' in Canada: A Delayed Opportunity for the Indigenization of Islamic Legal Rulings." University of St. Thomas Law Journal 7 (2010): 559.

Kutty, Faisal. "The Kutty 'Islamic Law' Flowchart,” 24 September 2014. http:// www.islamiclawflowchart/.

Labib, S. "Capitalism in Medieval Islam." Journal of Economic History 29, no. 1 (March 1969): 79-140.

Langah, Waseem Ahmad. Islamic Banking in the UK: Challenges and Opportunities, 25 February 2009. Retrieved from https://ssrn.com/abstract=1349170.

Maljichi, Drita N. "Islamic Financial Markets and Institutions." Vizione 21 (2014): 291-292.

Marais, Richard. "Don't Call It Interest.” Forbes, 2007. https://www.forbes. com/forbes /2007/0723/122.html\#242132b74354.

Mayyasi, Alex. "Of Money and Morals." Aeon, 2017. Retrieved from https:// aeon.co/essays/how-did-usury-stop-being-a-sin-and-become-respectablefinance.

Murababah Trade Financing. Maldives Islamic Bank. http://www.mib.com.mv/ pages/view/murabahah-trade-financing.

Nasser, Shanifa. "Muslim Mortgage Kingpin Led Investigators on 'Treasure Hunt' for Missing Gold: Crown.” CBC News, 2017. https://www.cbc. $\mathrm{ca} /$ news/canada/toronto/omar-kalair-muslim-madoff-shariah-mortgages-1. 4390002 .

Nehad, A., and Khanfar, A. "A Critical Analysis of the Concept of Gharar in Islamic Financial Contracts: Different Perspectives." Journal of Economic Cooperation and Development 37 no. 1 (2016): 1-24. http://www.sesric.org/ pdf.php?file=ART14103001-2.pdf. 
Nienhaus, Volker. "IFSB Working Paper on Financial Consumer Protection in Islamic Finance. IFSB Working Paper Series." Islamic Financial Services Board, 2015.

Nizami, Shah M. “Islamic Finance: The United Kingdom's Drive to Become the Global Islamic Finance Hub and the United States' Irrational Indifference to Islamic Finance." Suffolk Transnational Law Review 34, no. l (2011): 219.

Oseni, Umar A., Abu Umar Faruq Ahmad, and M. Kabir Hassan. "The Legal Implications of 'Fatwā Shopping' in the Islamic Finance Industry." Arab Law Quarterly 30, no. 2 (2016): 102-137.

Pasha, Shaheen, and Cameron French. "Canada Bankruptcy May Hurt Islamic Finance in N. America." Reuters, 2011. https://www.reuters.com/article/ canada-islamic-bankruptcy-idUSL5E7MT3KY20111205.

Pock, Alexander. Strategic Management in Islamic Finance. Berlin: Springer Science \& Business Media, 2007.

Qadri, Shahzad. "Islamic Banking-An Introduction." Business Law Today 17, no. 6 (2007): 59.

Qazi, Irfan. "Murabaha Financing vs. Lending on Interest," 2008. Retrieved from https://ssrn.com/abstract=180365l or https://doi.org/10.2139/ssrn. 1803651 .

Rammal, Hussain Gulzar. "Financing Through Musharaka: Principles and Application." Business Quest, 2004. Retrieved from https://ssrn.com/abstract= 1442430.

Reda, Ayman. Prophecy, Piety, and Profits: A Conceptual and Comparative History of Islamic Economic Thought. New York: Palgrave Macmillan, 2018.

Richardson, Christopher F. "Islamic Finance Opportunities in the Oil and Gas Sector: An Introduction to an Emerging Field.” Texas International Law Journal 42 (2006): 119-123.

Salah al-Sawi. A Polite Reconsideration of the Fatwa Permitting InterestBased Mortgages for Buying Homes in Western Societies, translated by Usama Hasan, 21 June 2001. https://unityl.files.wordpress.com/2009/06/ analysis-of-fatwas-on-mortgages.pdf.

Saleem, Muhammad. Islamic Banking-A \$300 Billion Deception: Observations and Arguments on Riba (Interest or Usury), Islamic Banking Practices, Venture Capital and Enlightenment. Bloomington: Xlibris Corporation, 2006.

Schoon, Natalie, and Julinda Nuri. "Comparative Financial Systems in Judaism, Christianity and Islam: The Case of Interest," 2012. Retrieved from https:// ssrn.com/abstract=2126503 or http://dx.doi.org/10.2139/ssrn.2126503.

Seputis, Jasmine. "2 Men Defrauded Shariah-Compliant Mortgage-Holders of Millions of Dollars, Crown Tells Trial." CBC News, 2018. https://www.cbc. $\mathrm{ca} /$ news/canada/toronto/2-men-defrauded-shariah-compliant-mortgageholders-of-millions-of-dollars-crown-tells-trial-1.4867083. 
Seznec, Jean-François. "Ethics, Islamic Banking and the Global Financial Market." Fletcher Forum of World Affairs 23, no. 1 (1999): 161.

Shaikh, Salman Ahmed. "A Brief Review \& Introduction to Practiced Islamic Banking \& Finance," 14 January 2010. Retrieved from https://ssrn.com/ abstract $=1536943$ or https://doi.org/10.2139/ssrn.1536943.

Shaikh, Salman Ahmed. "A Critical Analysis of Mudarabah \& A New Approach to Equity Financing in Islamic Finance." Journal of Islamic Banking o Finance (2011). Retrieved from https://ssrn.com/abstract=1930173.

Staff Writer. "Islamic Finance Assets Forecast to be Worth $\$ 3.2$ trn by 2020." Arabian Business, 7 August 2016. https://www.arabianbusiness.com/islamicfinance-assets-forecast-be-worth-3-2trn-by-2020-641156.html.

Statistics Canada. 2011 National Household Survey: Data Tables, 99-010X2011032. Ottawa, 1991.

Stubing, Darren. "Islamic Finance Held Back by Lack of Supervision, Liquidity." Global Finance, 2015. https://www.gfmag.com/magazine/may-2015/lacksupervision-liquidity-holding-back-islamic-finance.

Sweeney, Annie. "Guilty Plea in Fraud Scheme That Targeted Muslim community." The Chicago Tribune, 28 March 2011. https://www.chicagotribune. com/news/ct-xpm-2011-03-28-ct-met-muslim-fraud-guilty-20110328-story. html.

Terrell, Ron. "Islamic Banking: Financing Terrorism or Meeting Economic Demand?" (thesis). Naval PostGraduate College, 2007 https://apps.dtic.mil/ dtic/tr/fulltext/u2/a475770.pdf.

Thomas, Abdulkader, Stella Cox, and Bryan Kraty. Structuring Islamic Finance Transactions. Linnius, 2005.

Thomson Reuters. Canada Islamic Finance Outlook 2016 at 58, 2015. http:// www.tfsa.ca/storage/reports/Canada_Islamic_Finance_2016.pdf.

Uddin, Md Akther. Principles of Islamic Finance: Probibition of Riba, Gharar and Maysir. Kuala Lumpur, Malaysia: INCEIF, 2015. https://mpra.ub.unimuenchen.de/67711/1/MPRA_paper_67711.pdf.

Udovitch, A. "Bankers Without Banks: Commerce, Banking and Society in the Islamic World of the Middle-Ages." In The Dawn of Modern Banking, edited by the Centre for Medieval and Renaissance Studies. University of California: Los Angeles, 1979.

Waemustafa, W. "Theory of Gharar and Its Interpretation of Risk and Uncertainty from the Perspectives of Authentic Hadith and the Holy Quran: Review of Literatures," 2015. http://repo.uum.edu.my/18860/1/Wae_gharar.pdf.

Wafik, Grais and Matteo Pellegrini. Corporate Governance and Shariah Compliance in Institutions Offering Islamic Financial Services. 2006. World Bank Policy Research Working Paper No. 4054.

Warde, Ibrahim. "The Revitalization of Islamic Profit-and-Loss Sharing." Proceedings of the Third Harvard University Forum on Islamic Finance: Local 
Challenges, Global Opportunities, 199-211. Cambridge, MA: Center for Middle Eastern Studies, Harvard University, 1999. http://ifpprogram.com/ $\operatorname{login} /$ view_pdf/?file=The $\% 20$ Revitalization $\% 20$ of $\% 20$ Islamic\%20Profit-andloss\%20Sharing.pdf\&type $=$ Project_Publication.

Weber, Max. Economy and Society. Berkeley, CA: University of California Press, 1979.

Weitzman M. L., D. L. Kruse. "Profit Sharing and Productivity." In Blinder AS Paying for Productivity: A Look at the Evidence, 95-142. Washington, DC: Brookings Institution, 1990.

Wilson, Rodney. Capital Flight Through Islamic Managed Funds. Edinburgh: Edinburgh University Press, 2004.

Zaher, Tarek S., and M. Kabir Hassan. "A Comparative Literature Survey of Islamic Finance and Banking." Financial Markets, Institutions \& Instruments 10, no. 4 (2001): 155-199.

Zaman, Arshad. "Sayyid Abu'l A'la Maududi on Islamic Economics: A Review Article." Islamic Studies 50, no. 3-4 (2011): 303-323. Retrieved from https://ssrn.com/abstract=2225711.

Zingales, L. "Does Finance Benefit Society?" Journal of Finance 70, no. 4 (2015): 1327-1363.

Open Access This chapter is licensed under the terms of the Creative Commons Attribution 4.0 International License (http://creativecommons.org/licenses/ by $/ 4.0 /)$, which permits use, sharing, adaptation, distribution and reproduction in any medium or format, as long as you give appropriate credit to the original author(s) and the source, provide a link to the Creative Commons license and indicate if changes were made.

The images or other third party material in this chapter are included in the chapter's Creative Commons license, unless indicated otherwise in a credit line to the material. If material is not included in the chapter's Creative Commons license and your intended use is not permitted by statutory regulation or exceeds the permitted use, you will need to obtain permission directly from the copyright holder.

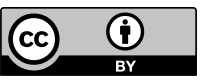




\title{
Christianity and Inequality in the Modern United States
}

\author{
Heath W. Carter
}

We are living through what many experts are calling a new Gilded Age, an era that is nothing short of historic when it comes to inequality. ${ }^{1}$ Its contours can be measured in a variety of ways. Consider, for example, that in 1973 the top $1 \%$ of American earners boasted just $9.2 \%$ of all income. Today they command fully $21 \%$. One has to go all the way back to the late 1920s, just prior to the Great Depression, to find comparable numbers. ${ }^{2}$ But the nation's wealth gap is arguably even more striking. An Institute for Policy Studies report found that, as of 2017, "the

${ }^{1}$ See, for example, Paul Krugman, "Why We're in a New Gilded Age," The New York Times, 2014, available via https://www.nybooks.com/articles/2014/05/08/ thomas-piketty-new-gilded-age/ (accessed 7 August 2018); and Eric Posner and Glen Weyl, "The Real Villain Behind Our New Gilded Age," The New York Times, 2018, available via https://www.nytimes.com/2018/05/01/opinion/monopoly-power-new-gildedage.html (accessed 7 August 2018).

${ }^{2}$ See Estelle Sommeiller and Mark Price, "The New Gilded Age: Income Inequality in the U.S. by State, Metropolitan Area, and County," Economic Policy Institute, 2018, available via https://www.epi.org/files/pdf/147963.pdf (accessed 7 August 2018).

H. W. Carter $(\bowtie)$

Princeton Theological Seminary, Princeton, NJ, USA

(C) The Author(s) 2020

T. Akram and S. Rashid (eds.), Faith, Finance, and Economy, https://doi.org/10.1007/978-3-030-38784-6_8 
three wealthiest Americans-Bill Gates, Jeff Bezos, and Warren Buffettowned more wealth than the entire bottom half of the American population combined, a total of 160 million people or 63 million households." 3 One common response to such statistics is to stress their relativity: sure, there may be a widening gap between rich and poor in the United States, but even the poor here are rich by global standards. But this perspective may lead some to underestimate the existence of real-and in some cases, outright lethal—suffering right here in the land of plenty. In Chicago, life expectancy varies by more than 15 years depending on one's census tract, with a range extending from 83.3 years on the Near North Side (where household incomes exceed $\$ 77,000$ per year) to just 68.2 years in West Garfield Park (where household income is just under $\$ 24,000$ per year). ${ }^{4}$ Between the extremes, wage stagnation is pervasive, with middle-income workers' real wages increasing only $0.2 \%$ per year over the last forty years, even as low-wage workers have seen a $5 \%$ decline in their real wages over the same period. ${ }^{5}$

Whatever the similarities between the days of Carnegie, Rockefeller, and Vanderbilt and our own, there remains this fundamental difference: late nineteenth-century Christians were less inclined to give inequality their "amen." In the face of the original Gilded Age's notorious disparities, ordinary believers built a variety of movements challenging the deep structures of industrial capitalism, contributing in the process to an unprecedented, nationwide ferment regarding the shape of a moral economy. On this particular front the analogy to our time breaks down. After all, the contemporary social movement most often identified with these issues, Occupy Wall Street, enjoyed tepid support, at best, from the nation's churches, which is perhaps partly why it proved such a flash in the pan. It left only a rhetorical flourish (the $1 \%$ vs. the $99 \%$ ) in its wake-one

${ }^{3}$ Chuck Collins and Josh Hoxie, "Billionaire Bonanza: The Forbes 400 and the Rest of Us," Institute for Policy Studies, 2017, available via https://ips-dc.org/ wp-content/uploads/2017/11/BILLIONAIRE-BONANZA-2017-FinalV.pdf (accessed 7 August 2018).

${ }^{4}$ Bijou R. Hunt, Gary Tran, and Steve Whitman, "Life Expectancy Varies in Local Communities in Chicago: Racial and Spatial Disparities and Correlates," Journal of Racial and Ethnic Health Disparities 2, no. 4 (December 2015): 425-433.

${ }^{5}$ Lawrence Mishel, Elise Gould, and Josh Bivens, "Wage Stagnation in Nine Charts," Economic Policy Institute, 6 January 2015, available via https://www.epi.org/files/ 2013/wage-stagnation-in-nine-charts.pdf (accessed 7 August 2018). 
that has failed to brighten the prospects of the labor movement, which today enrolls only $6.5 \%$ of private sector workers. ${ }^{6}$

Spiraling inequality has many sources, of course, but in this essay I will explore its spiritual roots. Historians of American Christianity have often taken denominational and/or theological conflict as a central plotline, crafting stories about rivalries between Baptists and Methodists, Protestants and Catholics, fundamentalists and modernists, and so on. ${ }^{7}$ These stories are certainly revealing in their own right. But they often conceal another central fault line in the history of modern American Christianity, one that cuts straight through denominations and across theological camps: namely, the moral status of inequality. For more than one hundred and fifty years American Christians have been deeply divided about not just the sources of inequality-whether it derives first and foremost from individual failings or from social structures-but also about whether faithful believers are obligated to join the fight against it. In this chapter I will offer a brief overview of these battles from the first Gilded Age to our own, tracing them through four distinct phases of development. It will become clear that this struggle has often involved a tug-of-war between church leaders and believers at the grassroots, with all parties well aware that struggles over the meaning of Christianity for the modern world have major implications not only for the churches but also for the soul of the nation.

This chapter may also be read as a concise introduction to the history of social Christianity, a heterogeneous tradition which arose from the grassroots in the nineteenth century and which reached the apex of its influence in the mid-twentieth century. This tradition has at its core several distinctive intuitions: (1) that inequality is sinful; (2) that the source of inequality is, first and foremost, not within the individual but without, in the systems and structures of society; and therefore; and (3) that Christian faith requires participation in fights for the reform and reconstruction of unjust systems. Over the course of the hundred years stretching form

6 "Union Members Summary," Bureau of Labor Statistics, 19 January 2018, available via https://www.bls.gov/news.release/pdf/union2.pdf (accessed 7 August 2018).

${ }^{7}$ This is especially characteristic of the grand narrative tradition pioneered by Robert Baird, whose landmark 1844 book, Religion in America, or, An account of the origin, progress, relation to the state, and present condition of the evangelical churches in the United States: with notices of the unevangelical denominations divvied the nation's churches into "evangelical" and "unevangelical" camps. 
the end of the Civil War to the apex of the modern Civil Rights Movement, a vast and diverse array of social Christians sought to vanquish American inequality. They came as close as anyone ever has. Only when they began to falter in the face of mighty headwinds did our new Gilded Age come into view.

\section{Phase One: Grassroots Uprisings, i865-i900}

The late nineteenth century was an age of stark contrasts: in the experiences of rich and poor, to be sure, but also in the reactions of the institutional churches and everyday Christians to the jaw-dropping inequality in their midst. Across denominations, throughout these postbellum decades, the clergy largely failed to champion structural solutions. The American Catholic hierarchy proceeded cautiously in all social and political affairs. While the Church's numbers were growing exponentially, its position in a broader society long prone to fits of anti-immigrant and anti-Catholic sentiment remained tenuous. Priests, bishops, and especially nuns, poured their resources into charitable endeavors during these years in a heroic attempt to meet the needs of the faithful without causing too much of a stir. ${ }^{8}$ Meanwhile, their Protestant counterparts, who retained significant cultural authority even in the wake of the theological crisis that was the Civil War, tended to champion a classical liberalism that attributed widespread poverty to the sins of the poor. ${ }^{9}$

Take, for example, the case of the Reverend David Swing, a nationally renowned Presbyterian minister who is best remembered in American religious history for his pathbreaking theological liberalism. ${ }^{10}$ In the early 1870s he was run out of the Presbyterian Church for his low view of biblical authority and reinterpretation of historic Christian doctrines. But during those same years, amid the rise of the modern labor movement,

\footnotetext{
${ }^{8}$ On the centrality of nuns in particular, see Suellen Hoy, Good Hearts: Catholic Sisters in Chicago's Past (Urbana: University of Illinois Press, 2006); and Maureen Fitzgerald, Habits of Compassion: Irish Catholic Nuns and the Origins of New York's Welfare System (Urbana: University of Illinois Press, 2006).

${ }^{9}$ For more on the damage the Civil War wreaked on Protestant America, see Mark A. Noll, The Civil War as a Theological Crisis (Chapel Hill: University of North Carolina Press, 2006).

${ }^{10}$ See, for example, William R. Hutchison, The Modernist Impulse in American Protestantism (Durham: Duke University Press, 1976).
} 
Swing made a name for himself as a staunch defender of laissez faire economics. In 1874, amid one particularly severe economic downturn, Swing declared in no uncertain terms, "The conflict between classes in the cities of our country is not a conflict between labor and capital, but between successful and unsuccessful lives." In contrast with feudal Europe, the United State was, in Swing's estimation, a land of opportunity, one in which the poor were without excuse. He went on:

The reason is the man who raves about the relief fund is not in as easy circumstances as, for example, George Armour, is because he did not come here thirty years ago, and heave trunks at a hotel and invest each ten dollars in a town lot. The reason why Mr. Hoffman's poor man is not wealthy as Wirt Dexter is because he did not go to a country school as Dexter did, and then bend down to twenty years of bondage at the law, studying cases far into the night.

Holding fast to an important vein of antebellum conventional wisdom, Swing went on to insist, "In our crisis the lesson taught the people should not be that labor and capital are enemies, but that capital in this country is labor. The rich man of today was the laborer of yesterday, and before the poor man of today there lies the hope of a better future... [which will come] by the old way of economy and industry and intelligence." 11

Countless ordinary believers begged to differ. During these same late nineteenth-century decades a variety of faith-infused movements against inequality sprung up at the grassroots. At least four deserve some mention here. First, workers banded together in unions and labor federations, which were also hotbeds of dissenting Christian theologies. ${ }^{12}$ Union leaders such as Andrew Cameron fought not only for shorter hours and higher wages, but also against the dominant strains of Christian economic thought. Cameron, the editor of the nation's most important labor paper throughout the 1860s and 1870s, wrote in one issue, "It is a startling fact that the modern pulpit has arrayed itself on the side of the oppressor; has almost invariably defended the aggressions of the monied power; and used its high and holy mission to pervert the ways of the Lord."13

${ }^{11}$ David Swing, "The Labor Turmoil," Alliance 1, no. 4 (3 January 1874): 2.

${ }^{12}$ See Heath W. Carter, Union Made: Working People and the Rise of Social Christianity in Chicago (New York: Oxford University Press, 2015).

13 “Rev. Dr. Westwood," Workingman's Advocate 5, no. 27 (30 January 1869): 2. 
As harsh as these words were, they did not proceed from the pen of an embittered outsider. Cameron was himself a believing Christian. While cognizant of widespread associations between working-class protest and godlessness, he denied any necessary link between the two. He declared in one editorial, "Our fight is not against Christianity, but against those who use it as a cloak to secure their selfish purposes," and in another that "the Gospel of Christ sustains [labor] in our every demand...the volume of Divine inspiration is the rock of truth upon which our 'pretensions' are founded."14

Women often found themselves on the outside looking in at the early labor movement, but as they gained ground within unions at the turn of the century, they too mounted arguments regarding the Christian basis of their activism. Agnes Nestor, a devout Catholic and leading figure within the Women's Trade Union League, took advantage of every available opportunity to implore middle-class Christian audiences to join working women's fight. To one particularly affluent congregation in Chicago's northern suburbs she declared, "You are so far removed from the life of the factory girl that you cannot understand the view she takes of life." In Nestor's view, this distance represented a shirking of Christian duty. She went on, "It is the work of the church to take an active instead of passive interest in the welfare of the mothers of to-morrow and lend its strength toward a betterment of conditions. $" 15$

A second grassroots movement sought to generate bonds of solidarity and ameliorate abhorrent conditions in the nation's industrializing "shock cities." With leading clergy largely paralyzed by the emergence of sprawling communities of working-class immigrants in their midst, middle-class women-who were themselves barred from the ministrytook the lead in forging connections. Reformers such as Mary McDowell and Jane Addams founded settlement houses in the poorest and most environmentally degraded urban neighborhoods, eager to live out Jesus's command to love one's neighbor as oneself. These houses soon became hubs of community activism, where residents organized to fight for everything from public baths, parks, and playgrounds to labor rights and women's suffrage. McDowell had come of age in Evanston, Illinois-a center

14 "Christianity a Failure," Workingman's Advocate 4, no. 42 (9 May 1868): 2; and “Liberal Christianity," Workingman's Advocate 4, no. 17 (16 November 1867): 2.

15 "In Factory Girl Plea; Piecework Is Scored," Chicago Record-Herald, 5 September 1910. 
for energetic Methodist reform, thanks in large part to the presence of the Women's Christian Temperance Union-and a strong Christian idealism animated her four decades in Chicago's stockyards district. Musing as to why more believers did not jump so readily into the urban fray, she reflected, "I sometimes have wondered whether or not Christians have a consciousness of a present Christ - a God in the flesh - a 'contemporary,' who is with us in all our crudeness. Must I not see Him here back-ofthe-Stockyards - a living presence making the struggle of the individual as well as of the group a sacred and holy thing?" $16 \mathrm{McD}$ Dowell was hardly alone among settlement house workers in sensing the nearness of Christ in poor neighborhoods. Addams traced their movement's roots to "a certain renaissance going forward in Christianity. The impulse to share the lives of the poor, the desire to make social service, irrespective of propaganda, express the spirit of Christ, is as old as Christianity itself." She went on to say, "I believe that there is a distinct turning among some young men and women toward this simple acceptance of Christ's message. They resent the assumption that Christianity is a set of ideas which belong to the religious consciousness, whatever that may be. They insist that it cannot be proclaimed and instituted apart from the social life of the community and that it must seek a simple and natural expression in the social organism itself." 17

On the other side of the Mason-Dixon line, meanwhile, a third grassroots movement took shape, as black freedom fighters sought to reconstruct the postbellum South on a racially egalitarian democratic basis. Black activists founded local chapters of the Union League and Republican Party across the region, while also establishing independent black churches at a remarkable clip. These fledgling institutions, whose very existence was a protest against the southern status quo ante, struggled just to survive amid the white paramilitary counterinsurgency of the early 1870s and so it's little surprise that black churches were not uniformly committed to activism as a central outworking of Christian faith. ${ }^{18}$ But

${ }^{16}$ Undated letter to Shailer Mathews, Mary McDowell Settlement records, Box 4, Folder 21, Chicago History Museum, Chicago, IL.

${ }^{17}$ Jane Addams, "The Subjective Necessity for Social Settlements," in Philanthropy and Social Progress (New York: Thomas Y. Crowell, 1893).

${ }^{18}$ See Steven Hahn, A Nation Under Our Feet: Black Political Struggles in the Rural South from Slavery to the Great Migration (Boston: Harvard University Press, 2003). 
a variety of streams of black Christian protest emerged despite imminent threats to life and limb. There was a black nationalist incarnation, embodied by African Methodist Episcopal (AME) bishop Henry McNeal Turner, who already in the late nineteenth century was arguing "God is a Negro." A second stream reflected the philosophy of Booker T. Washington, whose message of incremental racial uplift through economic development included an emphasis on the ethical dimensions of Christianity. His most formidable rival was W. E. B. Du Bois, who advanced a vision of a radical Jesus from outside the confines of the institutional church and who helped to inspire other black social Christians. Like Du Bois, Ida B. Wells rejected Washington' strategy in favor of a more radical politics, even as she poured her energies into a courageous and peripatetic anti-lynching campaign. Meanwhile, figures such as Nannie Burroughs and Adam Clayton Powell, Sr., mediated between Washington and Du Bois, modeling an approach that fused their best insights. Collectively, their struggle against a heinous Jim Crow order would prepare the way for civil rights activists to come. ${ }^{19}$

Finally, in parts of both the South and West, farmers joined together, sometimes even across racial lines, to power a fourth set of grassroots movements challenging the power of the nation's ruling elite. From the Grange and the Farmers' Alliance to the People's Party, their organizations were suffused with Christian ideas and powered by Christian activists who mounted a fierce assault on the monied powers of Wall Street. Expressing a "righteous indignation" at the ways that a complacent "churchianity" underwrote elite rule, they threw their weight behind a Populist movement that briefly gained national prominence in the early 1890s before flaming out and taking with it hopes for a progressive biracial political coalition. ${ }^{20}$ Their concerns found an enduring advocate in the person of William Jennings Bryan, an evangelical Christian and threetime presidential candidate, who declared in a legendary 1896 speech at the Democratic National Convention, "we shall answer their demands for a gold standard by saying to them, you shall not press down upon the

${ }^{19}$ Gary Dorrien, The New Abolition: W. E. B. Du Bois and the Black Social Gospel (New Haven: Yale University Press, 2015).

${ }^{20}$ Joe Creech, Righteous Indignation: Religion and the Populist Revolution (Urbana: University of Illinois Press, 2006). 
brow of labor this crown of thorns. You shall not crucify mankind upon a cross of gold." 21

\section{Phase Two: Institutional Breakthroughs, i900-I935}

By the early twentieth century, the nation's sundry industrial crises and the intentional pressure exerted by these grassroots movements had generated a serious crisis for the leaders of the nation's Christian institutions: if they did not embrace a more egalitarian gospel-and fast-it appeared they might soon forfeit their credibility with ordinary people. Venerable dreams of "Christian America" seemed suddenly imperiled. These anxieties empowered scattered reformers on the inside, who systematized and popularized social Christian ideas, hoping to capture the hearts of their fellow middle-class Christians.

The best known was Walter Rauschenbusch, who had gotten his start as a pastor in New York City's hardscrabble Hell's Kitchen neighborhood and whose 1907 book Christianity and the Social Crisis went on to become an immediate sensation, selling more than 50,000 copies. ${ }^{22}$ Drawing on modern biblical scholarship but also infused with evangelical zeal, the book located Jesus in the prophetic tradition of the Hebrew scriptures and argued that the late antique church's embrace of wealth and empire had been a conspicuous betrayal of its founder. Rauschenbusch insisted that it was not too late to right the course, but that it would require a fundamental recommitment to Christianity's "essential purpose": "to transform human society into the kingdom of God by regenerating all human relations and reconstituting them in accordance with the will of God." 23 The book resonated with white middle-class Protestant audiences precisely because it seemed to illumine a way forward through the crises which the Christian activists of the Gilded Age had intentionally brought to a head. It proved a source of particular encouragement to the many who were distressed about ordinary believers' growing disaffection from the churches. A Baptist minister in Concord, New

${ }^{21}$ Michael Kazin, A Godly Hero: The Life of William Jennings Bryan (New York: Anchor Books, 2006).

${ }^{22}$ Christopher H. Evans, The Kingdom Is Always but Coming: A Life of Walter Rauschenbusch (Grand Rapids: William B. Eerdmans Publishing Company, 2004).

${ }^{23}$ Walter Rauschenbusch, Christianity and the Social Crisis (New York: Macmillan, 1907), xiii. 
Hampshire, penned a letter in the winter of 1908 relaying that he had read the book the year before "and ever since it has been working in my mind." He had spent the months immediately prior "trying to do something to arouse my church to the situation and to get into touch with the labor union men in Concord." His sermon on "The Church and the Labor Question" had in fact produced a relational breakthrough with the workers organized through that city's Central Labor Union, giving him hope for the future of the American churches: "If they are ready in conservative, aristocratic old Concord, they are almost anywhere," he reflected. ${ }^{24}$

They were, indeed, ready elsewhere. These were the decades when social gospels gained a significant institutional foothold. Nearly every denomination created boards and committees to consider and coordinate responses to a vast range of social problems, ranging from child labor and prostitution to temperance and race relations. In 1903 alone the Presbyterian Church founded a Department of Church and Labor, and the Congregational and Episcopal Churches established commissions to investigate industrial problems. The Methodists established a Federation for Social Service in 1907 and soon thereafter endorsed a "Social Creed" that called "For the principle of conciliation and arbitration in industrial dissensions," "For a living wage in every industry," and "For such regulation of the conditions of labor for women as shall safeguard the physical and moral health of the community." The following year the fledgling Federal Council of Churches (FCC) — which would develop into a powerful vehicle for Protestant collaboration on social problems ratified that creed. Just over a decade later Roman Catholics established their own hub for cooperation in the National Catholic Welfare Conference (NCWC). For years to come its leaders, including notable figures such as Father John Ryan and Dominican Sister Vincent Ferrer, would devote themselves to bringing a tradition of modern Catholic economic teaching, inaugurated by the Gilded Age encyclical Rerum Novarum, to the masses. ${ }^{25}$

${ }^{24}$ Virgil V. Johnson to Walter Rauschenbusch, 11 December 1908, Box 25, Folder 3, Walter Rauschenbusch Papers, American Baptist Historical Society, Atlanta, GA.

${ }^{25}$ See Carter, Union Made, 150-182. 
During these pivotal early twentieth-century decades social Christians moreover attained greater clout within local, state, and national governments, helping to promote certain kinds of egalitarian reforms. From Samuel M. "Golden Rule" Jones, the mayor of Toledo, Ohio, from 18971899 to J. Stitt Wilson, the Christian socialist mayor of Berkeley, California, from 1911 to 1913 , they made major contributions to municipal reform. Others such as Norman Thomas sought political office but never attained it. A graduate of Union Theological Seminary, where he read Rauschenbusch and more, Thomas ran for governor of New York in 1924, mayor of New York City in 1925 and 1929, and then for president of the United States as a socialist candidate on six different occasions. He proved influential despite his penchant for losing, about which he had a good sense of humor: "I am not the champion of lost causes, but the champion of causes not yet won," he liked to say. ${ }^{26}$

The New Deal was among the clearest of causes won for Christians devoted to the fight against inequality. The unprecedented avalanche of legislation signed by President Franklin D. Roosevelt in his first hundred days alone created a larger and more interventionist federal government than the nation had ever known. Many members of the Cabinet were steeped in social Christianity, including Frances Perkins, who as Secretary of Labor from 1933 to 1945 was one of the welfare state's foremost architects. As her biographer, George Martin, writes, "What Perkins chose to do was determined by her religion. Many Democrats supported the Social Security Act because it attracted votes; others, for humanitarian reasons; Perkins, 'for Jesus' sake,' because it brought the City of God closer to the cities of toil and industry." 27 Her colleague, Secretary of the Interior Harold Ickes, made these connections explicit when he addressed the leaders of the Presbyterian Church USA in the spring of 1934. "Christ wanted men and women to live upright lives," Ickes acknowledged, "but he also wanted them to have for each other understanding and good will and mutual helpfulness. He wished them to be good neighbors. He hated

\footnotetext{
${ }^{26}$ Robert Hyfler, Prophets of the Left: American Socialist Thought in the Twentieth Century (Westport, CT: Greenwood Press, 1984).

${ }^{27}$ George Martin, Madam Secretary, Frances Perkins (Boston: Houghton Mifflin Company, 1976), vii.
} 
injustice with a righteous hatred. His whole life was a fight against oppression." 28 In Ickes's estimation the New Deal reflected not just the principles of the Golden Rule but the social vision of the savior himself. He closed the speech with the confident declaration, "If our civilization is to advance, if we are to establish on this earth the social state envisaged by the Founder of Christianity, the citadel of entrenched privilege must be carried, and in due course, by the grace of God, it will be carried." 29 This view resonated at the grassroots-perhaps never before had the immorality of economic inequality seemed so intuitive to so many people-but it also inspired a backlash in high places. More on that below, but for the time being, suffice it to say that by the late-1930s, social Christianity's influence over both church and state was receding in the face of concerted political and theological resistance. Its future would rest once more in the hands of ordinary believers on the ground.

\section{Phase Three: On the March, I935-I975}

During the years stretching from roughly 1935 to 1975 ordinary Christians committed to a more egalitarian society fundamentally changed the nation. Throughout the late 1930s everyday believers poured into the Congress of Industrial Organizations, which organized workers across lines of race and gender, constructing the kind of formidable big tent union that had so long proved elusive. Meanwhile, a Catholic Worker movement founded in New York City by Dorothy Day and Peter Maurin quietly gained momentum. Day was deeply influenced by the tradition of Catholic social teaching that had emerged in the Gilded Age and Progressive Era. But unlike many of her fellow believers, she doubted that social salvation would be achieved through New Deal-style bureaucracies. Later in life she reflected, "Young people say, What good can one person do? What is the sense of our small effort? They cannot see that we must lay one brick at a time, take one step at a time, we can be responsible only for the action of the present moment. But we can beg for an increase

\footnotetext{
28 "New Deal Is Based on Christ's Tenets, Ickes Says in Talk," Chicago Daily Tribune, 24 May 1934.

${ }^{29}$ Department of the Interior Memorandum for the Press, Address by Honorable Harold L. Ickes, Secretary of the Interior, at meeting of Presbyterian General Assembly, 24 May 1934, Folder 63a, Harold L. Ickes Papers, Library of Congress, Washington, DC.
} 
of love in our hearts that will vitalize and transform all of our actions, and know that God will take them and multiply them, as Jesus multiplied the loaves and the fishes." ${ }^{30}$ While many doubted the effectiveness of Day's incarnational approach, it caught on well beyond New York City. Catholic Workers houses sprouted up across the country and out of them grew many other movements as well, including one which became a force in 1940s Detroit.

Home to Walter Reuther and the powerful United Automobile Workers (UAW) union, World War II-era Motor City was also the place where arguably the most influential chapter of the Association of Catholic Trade Unionists (ACTU) took shape. The organization infused Detroit's union locals with a progressive Catholic spirit. One chapter affiliated with Chrysler UAW Local 7 declared in its newspaper, "WE, AS CATHOLICS, HAVE A SPECIAL RESPONSIBILITY TO SEE THAT OUR UNIONS ARE EFFECTIVE, MILITANT, AND RUN PROPERLY." 31 1940s Detroit served also as a headquarters for Claude Williams' People's Institute of Applied Religion. Williams had imbibed the social Christian radicalism of southern churchman Alva Taylor and now sought to bring it to bear on the racism and classism that structured life in mid-century Detroit. He took his egalitarian message directly to the shop floors, even as he galvanized a variety of new initiatives involving also church youth groups and everyday ministers. ${ }^{32}$ What was happening in Detroit was connected to developments in other industrial cities as well. In Chicago Bishop Sheil had forged close relationships with leaders in the Congress of Industrial Organizations and in Washington, DC the National Catholic Welfare Conference was sponsoring summer schools for women workers.

Even as the labor movement gained steam in the postwar United States, so did a massive, faith-infused civil rights movement. The breakthroughs of the 1950s and 1960s did not come out of nowhere. Activists built on organizing traditions cultivated over the course of generations.

${ }^{30}$ Dorothy Day, Loaves and Fishes: The Inspiring Story of the Catholic Worker Movement (New York: Orbis Books, 1997).

${ }^{31}$ Matthew Pehl, The Making of Working-Class Religion (Urbana: University of Illinois Press, 2016).

${ }^{32}$ Erik S. Gellman and Jarod Roll, The Gospel of the Working Class: Labor's Southern Prophets in New Deal America (Urbana: University of Illinois Press, 2011). 
The movement was religiously and racially diverse, but at its very center were black Christians whose gospel was intuitively egalitarian. Mississippi activist Fannie Lou Hamer did not need to read Walter Rauschenbusch or W. E. B. Du Bois to know that God longed for her people to be free. But the movement's most influential spokesperson, the Reverend Martin Luther King, Jr., had read both of them and many more besides. King's speeches moved seamlessly between the biblical prophetic tradition and the nation's republican ideals, and brought both to bear on the systemic injustice of the contemporary American scene. The everyday activists who showed up for rallies and bore the brunt of the often brutal opposition were the guarantors of his leverage with high-level negotiators, who were in turn often anxious, especially given the Cold War context, to avoid appearing undemocratic. As mass meetings, marches, boycotts, sit-ins, and speeches parlayed into historic breakthroughs in the form of court decisions and federal legislation, social Christians collaborated with numerous others to leave arguably their most lasting mark on American society. ${ }^{33}$

Before all was said and done, what began in Detroit and Montgomery would reverberate all the way to California, where in the 1960s and 1970s Dolores Huerta and Cesar Chavez mobilized a movement of Latino and Filipino workers that brought the state's mightiest growers to the bargaining table. Marching workers carried images of the Virgin of Guadalupe and framed their protests as pilgrimages. Chavez himself had been deeply influenced by a Catholic priest who introduced him to the church's social teaching, among other things. In his 1966 Plan of Delano he hearkened back to the Gilded Age encyclical Rerum Novarum, declaring, "All men are brothers, sons of the same God; that is why we say to all men of good will, in the words of Pope Leo XIII, 'Everyone's first duty is to protect the workers from the greed of spectators? who use human beings as instruments to provide themselves with money. It is neither just nor human to oppress men with excessive work to the point where their minds become enfeebled and their bodies worn out." Thanks in no small part to the

${ }^{33}$ See David L. Chappell, A Stone of Hope: Prophetic Religion and the Death of Jim Crow (Raleigh, NC: University of North Carolina Press, 2005); Mary L. Dudziak, Cold War Civil Rights: Race and the Image of American Democracy (Princeton: Princeton University Press, 2000); and Taylor Branch's prize-winning trilogy on America in the King Years. 
tenacity of the farm workers themselves, by the early 1970s the movement had successfully organized much of the industry. ${ }^{34}$ A Social Christian tradition that had arisen at the grassroots now ushered the nation to the cusp of the mountaintop-only to fall back down.

\section{Phase Four: Toward a New Gilded Age}

How did the United States fall from that mountaintop to an age of nearly unprecedented inequality? It's a complex and multi-faceted story, but major shifts in the American Christian landscape help to explain current trends. The story extends at least back to the 1930s. From very early in FDR's administration the heads of the National Association of Manufacturers cultivated relationships with Christian clergymen like James Fifield, a theologically liberal and economically libertarian Congregationalist based out of Los Angeles. Fifield founded an organization called Spiritual Mobilization, which sought to defeat the New Deal by rallying clergy and ordinary believers alike to the gospel of free enterprise. Whereas many social Christians found in the Bible a plain justification for redistributionist programs, Fifield and others of his ilk argued that the free market way was not only the American way but also God's. ${ }^{35}$ They set out to dismantle the social gospel institutions that had been so painstakingly constructed earlier in the twentieth century.

By the early 1950s, for example, Fifield was coordinating a frontal assault on the Congregationalist Church's Council for Social Action. He sent letters to leading churchmen, which stated, "Some of us have become very much concerned about the Council for Social Action of our Congregational Denomination. Our Methodist friends tossed that group out of their General Conference a year or so ago." He went on to explain, "It certainly does not act for me and I am sure not for you and most Congregationalists - yet it maintains a registered lobbying office in Washington, and presumes to speak on many issues which are of vital importance in

${ }^{34}$ Luis D. Leon, The Political Spirituality of Cesar Chavez: Crossing Religious Borders (Oakland: University of California Press, 2014).

${ }^{35}$ See Kevin Kruse, One Nation Under God: How Corporate America Invented Christian America (New York: Basic Books, 2015); and Darren Dochuk, From Bible Belt to Sunbelt: Plain-Folk Religion, Grassroots Politics, and the Rise of Evangelical Conservatism (New York: W. W. Norton, 2011). 
relation to National and world trends." 36 When the head of the Council confronted Fifield about the discord he was sowing, he responded matter-of-factly, "my personal feeling about the Council for Social Action is exactly as it has been through the years and as I explained to you last time we talked; namely, that we should not have a Council for Social Action, that the net end result has been a liability rather than an asset."37

The campaign was hardly limited to California. The chair of one allied group, The Committee Opposing Congregational Political Action, was based in Minneapolis; its board included members from Connecticut, New York, Michigan, Illinois, and more. That group distributed a booklet with the ominous title "They're Using Our Church..." When one turned the page, the words TO PLAY POLITICS! appeared in capitalized and emboldened text. The authors went on to accuse the Council of favoring "socialized medicine," of having personal connections to "Communist Fronts," and of being soft on Russia and China. The booklet closed with an action plan for the reader to pursue and a choice quote from Abraham Lincoln: “...With Firmness In The Right, As God Gives Us To See The Right." 38 The coordinated effort proved highly effective. As one Congregationalist pastor went on to report to the Council for Social Action's leadership, "the CSA, as presently organized, is 'discredited' among many." 39 Christian libertarian crusaders such as Fifield did not struggle to find major boosters in both the philanthropic and corporate worlds. Groups such as Spiritual Mobilization struggled initially to gain traction at the grassroots but a number of larger factors and forces would work together, over time, to yield a new harvest of ordinary Christian converts to the gospel of free enterprise.

One such factor was the Cold War. Over the course of the nation's standoff with the Communist and atheistic Soviet Union it would come to seem to more and more believers that Christianity, free enterprise, and American patriotism were a match made in heaven. The specter of

\footnotetext{
${ }^{36}$ James W. Fifield, Jr., to Mr. W. H. Danforth, 24 September 1951, Box 1, Folder BR 5, Council for Social Action Papers, Congregational Library, Boston, MA.

${ }^{37}$ James W. Fifield, Jr., to Dr. Ray Gibbons, 1 November 1951, Box 1, Folder BR 5, Council for Social Action Papers, Congregational Library, Boston, MA.

38 “They're Using Our Church..." Booklet, Box 1, Folder BR 2, Council for Social Action Papers, Congregational Library, Boston, MA.

${ }^{39}$ Henry David Gray to Liston Pope, 13 June 1953, Box 1, Folder BR 5, Council for Social Action Papers, Congregational Library, Boston, MA.
} 
violent totalitarian regimes was raised to defeat even modest calls for economic redistribution and social welfare programs. Christian socialism, which had enjoyed a significant following of working-and-middle-class believers throughout the late nineteenth and early twentieth centuries, became not just taboo but in fact grounds for investigation and blacklisting. Meanwhile, savvy entrepreneurs such as Sam Walton, the founder of Wal-Mart, would capitalize on the opportunities the early Cold War revival presented, enveloping hard-nosed labor and supply chain practices in a service ethos and faith-and-family-friendly brand that resonated first across the Bible Belt and before long the entire land. For countless employees and customers alike, serving God and serving companies like Wal-Mart came to seem almost of a piece. ${ }^{40}$

Another key factor in the rise of grassroots conservatism was the white response to the Civil Rights movement. The resistance included an explicitly racist wing, which enjoyed strong support not only in the South but also in Northern cities where white residents, outraged by open housing laws, often turned viciously on black neighbors. This movement, whose figurehead was the arch-segregationist George Wallace, inflicted great damage, but its long-term impact paled in comparison to that of an emerging white "silent majority" whose unrelenting faith in meritocracy eroded support for structural approaches to addressing inequality. Its strongholds were the Sunbelt suburbs, which were also increasingly the nation's demographic center of gravity. The silent majority rejected New Deal-style programs in favor of colorblind, laissez faire policies, which contradicted many a denomination's social teaching, but which dovetailed seamlessly with the doctrines of a surging Christian libertarianism. ${ }^{41}$ This tension between official church positions and the faithful's economic outlook was not always apparent in local churches and parishes, far removed as they were from denominational headquarters. And with the 1980s emergence of a hard-charging Religious Right-which saw a role for the state in controlling individual behavior, but not in promoting distributive justice - any remaining whiff of tension between Christian convictions and neo-liberal economics evaporated for countless white Protestants and Catholics alike.

\footnotetext{
${ }^{40}$ Bethany Moreton, To Serve God and Wal-Mart: The Making of Christian Free Enterprise (Boston: Harvard University Press, 2009).

${ }^{41}$ Matthew D. Lassiter, The Silent Majority: Suburban Politics in the Sunbelt South (Princeton: Princeton University Press, 2006).
} 
Other key factors took shape far from the realm of formal politics. Throughout the twentieth century's final decades, millions of ordinary believers joined churches which taught that prosperity came not through gritty organizing efforts but rather through individual access to divine power. Drawing on a tradition in modern American life that stressed the power of positive thinking, preachers such as Houston's Joel Osteen argued, "You can change your world by changing your words." Millions more who did not attend prosperity churches still voraciously consumed therapeutic Christianities and their proliferating products: books, magazines, devotionals, music, clothing, and more, which blended faith and self-help for a generation that took pride in being spiritual but not religious. $^{42}$

Social Christianity never completely disappeared, but it was increasingly relegated to the margins of American life. Throughout the Reagan years and in the decades that followed it animated movements for nuclear disarmament and immigrant and refugee rights. Black social gospelers continued to prophesy against structural racism but their message largely failed to gain traction with a white Christian majority persuaded that the nation had addressed its original sin back in the Civil Rights era. Incontrovertible visual evidence of police brutality changed some white minds in the early twenty-first century. But in its initial phase at least, the Black Lives Matter movement succeeded more at calling attention to violations of individual rights than to the structural underpinnings of persistent racial inequality. On an even broader scale, if many ordinary believers had once seen structural inequality as a sin they were called to fight, it now came to seem almost natural and in some cases even God ordained. As older moral intuitions faded, a new refrain came into vogue: "That's just the way the market works." As that logic took hold, not just in many pulpits but also in the pews, it became clear: the dream of a more egalitarian society had flourished first at the grassroots and it withered there too.

\footnotetext{
${ }^{42}$ Kate Bowler, Blessed: A History of the American Prosperity Gospel (New York: Oxford University Press, 2013); Heather Hendershot, Shaking the World for Jesus: Media and Conservative Evangelical Culture (Chicago: The University of Chicago Press, 2004); R. Laurence Moore, Selling God: American Religion in the Marketplace of Culture (New York: Oxford University Press, 1994); and David W. Stowe, No Sympathy for the Devil: Christian Pop Music and the Transformation of American Evangelicalism (Raleigh: University of North Carolina Press, 2011).
} 
The impact is felt today across the nation. Arguably nothing so dramatically underscores the diminished status of social Christianity as the latterday collapse of the labor movement. A working paper published by several Princeton economists earlier this year underscored once more that unions remain one of the surest bulwarks against spiraling income inequality. ${ }^{43}$ Yet in the early twenty-first century-with fully seventy-seven percent of the nation's population still identifying as Christian-less than seven percent of private sector workers belong to unions. For social Christianswhose visions of justice rolling down like waters had, just a single generation before, transfixed the nation-such developments are clear evidence of a return to the wilderness.

But hope persists, even in the wilderness. Several years ago, for one long winter night, the daunting realities of our new Gilded Age seemed almost destined to be overcome. As the mass meeting got underway at Selma's Tabernacle Baptist Church, hundreds were still filing in, hoping to find a place to stand in the balcony or along the perimeter of the main sanctuary below. It was March 5, 2015, nearly fifty years to the day since the infamous "Bloody Sunday" march that had earned this otherwise unremarkable town, the seat of dirt poor Dallas County, Alabama, a place in the annals of the twentieth century. Many of the saints who powered the local movement long before Martin Luther King, Jr., ever set foot in Selma were seated in the first two rows. The choir got things off to a rousing start, but then halfway through its set a hush descended on the place. Someone was wheeling Amelia Boynton-frail now at 103 years old, but in her prime the most formidable thorn in the side of the area's white supremacist ruling class - to the front. Eyes that had not yet dried watered freely once more as the multiracial assembly belted out the lyrics of the old freedom song, "We Shall Overcome," and as NAACP President Cornell William Brooks invoked the memory of Medgar Evers, the martyred activist whose last words, as he lay bleeding, were "Sit me up! Turn me loose!" Stirring reflections from luminaries such as Jeremiah Wright and Bernice King followed, but it was the Reverend William J. Barber II who brought down the house. He began softly, even tentatively, but soon

${ }^{43}$ Henry S. Farber, Daniel Herbst, Ilyana Kuziemko, Suresh Naidu, "Unions and Inequality over the Twentieth Century: New Evidence from Survey Data" (working paper), available via https://dataspace.princeton.edu/jspui/bitstream/88435/ dsp01gx4lmm54w/3/620.pdf (accessed 8 August 2018). 
enough was thundering against contemporary manifestations of inequality, including the 2013 Supreme Court decision that had eviscerated the hard-won 1965 Voting Rights Act. Over and over Barber vowed that God's people must see this historic anniversary not as a "commemoration" but rather as a "consecration" to the work of justice and righteousness in our time. By the time he reached the climax of his address, the crowd was on its feet, applauding vigorously and shouting "Amen." The Spirit did not move like this nearly as often as it once did.

Prior to that evening in Selma, I had never heard of Barber. His is still not a household name, though his renown certainly grew when in 2016 he delivered a nationally televised address at the Democratic Convention. He earned a slot on that stage through his work galvanizing the "Moral Mondays" movement, which rallied thousands in protest of the North Carolina state legislature's sweeping tax cuts, funded in part by corresponding cuts to Medicaid and unemployment benefits. Some credit Barber's leadership with helping to unseat Republican Governor Pat McCrory in 2016, though notably, the legislature itself remains overwhelmingly dominated by the movement's conservative opponents. Barber has made clear that he rejects both the religious right and the religious left. His is not a partisan but rather a biblical movement. Last summer he reduced his obligations in North Carolina in order to focus on organizing a new "poor people's campaign" that he hopes will change the nation's "moral narrative." It will be an uphill fight.

We historians are not in the business of predicting what happens next. But this much seems clear: American Christians played pivotal roles in getting us into this New Gilded Age and we are in urgent need of a renewal of Christian economic thought and practices today if we are to have any hope of finding our way out.

\section{BIBLIOGRAPHY}

Addams, Jane. "The Subjective Necessity for Social Settlements." In Philanthropy and Social Progress. New York: Thomas Y. Crowell, 1893.

Bowler, Kate. Blessed: A History of the American Prosperity Gospel. New York: Oxford University Press, 2013.

Carter, Heath W. Union Made: Working People and the Rise of Social Christianity in Chicago. New York: Oxford University Press, 2015.

Chappell, David L. A Stone of Hope: Prophetic Religion and the Death of Jim Crow. Raleigh, NC: University of North Carolina Press, 2005. 
“Christianity a Failure." Workingman's Advocate 4, no. 42 (9 May 1868): 2.

Collins, Chuck, and Josh Hoxie. "Billionaire Bonanza: The Forbes 400 and the Rest of Us." Institute for Policy Studies, 2017. Available via https://ips-dc.org/wp-content/uploads/2017/11/BILLIONAIREBONANZA-2017-FinalV.pdf. Accessed 7 August 2018.

Creech, Joe. Righteous Indignation: Religion and the Populist Revolution. Urbana: University of Illinois Press, 2006.

Day, Dorothy. Loaves and Fishes: The Inspiring Story of the Catholic Worker Movement. New York: Orbis Books, 1997.

Dochuk, Darren. From Bible Belt to Sunbelt: Plain-Folk Religion, Grassroots Politics, and the Rise of Evangelical Conservatism. New York: W. W. Norton, 2011.

Dorrien, Gary. The New Abolition: W. E. B. Du Bois and the Black Social Gospel. New Haven: Yale University Press, 2015.

Dudziak, Mary L. Cold War Civil Rights: Race and the Image of American Democracy. Princeton: Princeton University Press, 2000.

Evans, Christopher H. The Kingdom Is Always but Coming: A Life of Walter Rauschenbusch. Grand Rapids: William B. Eerdmans Publishing Company, 2004.

Farber, Henry S., Daniel Herbst, Ilyana Kuziemko, and Suresh Naidu. "Unions and Inequality over the Twentieth Century: New Evidence from Survey Data." Working Paper. Available via https://dataspace.princeton.edu/jspui/ bitstream/88435/dsp0lgx4lmm54w/3/620.pdf. Accessed 8 August 2018.

Fitzgerald, Maureen. Habits of Compassion: Irish Catholic Nuns and the Origins of New York's Welfare System. Urbana: University of Illinois Press, 2006.

Gellman, Erik S., and Jarod Roll. The Gospel of the Working Class: Labor's Southern Prophets in New Deal America. Urbana: University of Illinois Press, 2011.

Hahn, Steven. A Nation Under Our Feet: Black Political Struggles in the Rural South from Slavery to the Great Migration. Boston: Harvard University Press, 2003.

Hendershot, Heather. Shaking the World for Jesus: Media and Conservative Evangelical Culture. Chicago: University of Chicago Press, 2004.

Hoy, Suellen. Good Hearts: Catholic Sisters in Chicago's Past. Urbana: University of Illinois Press, 2006.

Hunt, Bijou R., Gary Tran, and Steve Whitman. "Life Expectancy Varies in Local Communities in Chicago: Racial and Spatial Disparities and Correlates." Journal of Racial and Ethnic Health Disparities 2, no. 4 (December 2015): 425433.

Hutchison, William R. The Modernist Impulse in American Protestantism. Durham: Duke University Press, 1976.

Hyfler, Robert. Prophets of the Left: American Socialist Thought in the Twentieth Century. Westport, CT: Greenwood Press, 1984. 
"In Factory Girl Plea; Piecework is Scored." Chicago Record-Herald, 5 September 1910 .

Kazin, Michael. A Godly Hero: The Life of William Jennings Bryan. New York: Anchor Books, 2006.

Krugman, Paul. "Why We're in a New Gilded Age." The New York Times, May 8, 2014. Available via https://www.nybooks.com/articles/2014/05/ 08/thomas-piketty-new-gilded-age/. Accessed 7 August 2018.

Kruse, Kevin. One Nation Under God: How Corporate America Invented Christian America. New York: Basic Books, 2015.

Lassiter, Matthew D. The Silent Majority: Suburban Politics in the Sunbelt South. Princeton: Princeton University Press, 2006.

Lawrence Mishel, Elise Gould, and Josh Bivens, "Wage Stagnation in Nine Charts," Economic Policy Institute, 6 January 2015. Available via https://www.epi.org/files/2013/wage-stagnation-in-nine-charts.pdf. Accessed 7 August 2018.

Leon, Luis D. The Political Spirituality of Cesar Chavez: Crossing Religious Borders. Oakland: University of California Press, 2014.

“Liberal Christianity." Workingman's Advocate 4, no. 17 (16 November 1867): 2 .

Martin, George. Madam Secretary, Frances Perkins, vii. Boston: Houghton Mifflin Company, 1976.

Mishel, Lawrence, Elise Gould, and Josh Bivens. "Wage Stagnation in Nine Charts." Economic Policy Institute, January 6, 2015. Available via https://www.epi.org/files/2013/wage-stagnation-in-nine-charts.pdf. Accessed 7 August 2018).

Moore, R. Laurence. Selling God: American Religion in the Marketplace of Culture. New York: Oxford University Press, 1994.

Moreton, Bethany. To Serve God and Wal-Mart: The Making of Christian Free Enterprise. Boston: Harvard University Press, 2009.

"New Deal Is Based on Christ's Tenets, Ickes Says in Talk." Chicago Daily Tribune, 24 May 1934.

Noll, Mark A. The Civil War as a Theological Crisis. Chapel Hill: University of North Carolina Press, 2006.

Pehl, Matthew. The Making of Working-Class Religion. Urbana: University of Illinois Press, 2016.

Posner, Eric, and Glen Weyl. "The Real Villain Behind Our New Gilded Age." The New York Times, May 1, 2018. Available via https://www.nytimes.com/ 2018/05/01/opinion/monopoly-power-new-gilded-age.html. Accessed 7 August 2018.

Rauschenbusch, Walter. Christianity and the Social Crisis, xiii. New York: Macmillan, 1907.

“Rev. Dr. Westwood.” Workingman's Advocate 5, no. 27 (30 January 1869): 2. 
Sommeiller, Estelle, and Mark Price. "The New Gilded Age: Income Inequality in the U.S. by State, Metropolitan Area, and County." Economic Policy Institute, July 19, 2018. Available via https://www.epi.org/files/pdf/147963. pdf. Accessed 7 August 2018.

Stowe, David W. No Sympathy for the Devil: Christian Pop Music and the Transformation of American Evangelicalism. Raleigh: University of North Carolina Press, 2011.

Swing, David. "The Labor Turmoil." Alliance 1, no. 4 (3 January 1874): 2.

"Union Members Summary." Bureau of Labor Statistics, 19 January 2018. Available via https://www.bls.gov/news.release/pdf/union2.pdf. Accessed 7 August 2018.

Open Access This chapter is licensed under the terms of the Creative Commons Attribution 4.0 International License (http://creativecommons.org/licenses/ by $/ 4.0 /)$, which permits use, sharing, adaptation, distribution and reproduction in any medium or format, as long as you give appropriate credit to the original author(s) and the source, provide a link to the Creative Commons license and indicate if changes were made.

The images or other third party material in this chapter are included in the chapter's Creative Commons license, unless indicated otherwise in a credit line to the material. If material is not included in the chapter's Creative Commons license and your intended use is not permitted by statutory regulation or exceeds the permitted use, you will need to obtain permission directly from the copyright holder.

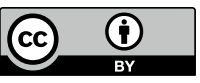




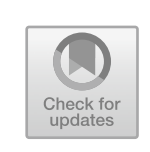

\title{
Faith and Work: Brave New World?
}

\author{
David W. Miller
}

\section{INTRODUCTION}

The venerable cultural etiquette queen of the early twentieth century, Emily Post, advised in her classic book, Etiquette in Society, in Business, in Politics, and at Home (1922) that polite company should never talk about sex, politics, or religion. These gradually became known to be the three taboos. The logic behind these taboos is that each of these topics are so emotive, so personal, and so difficult to talk about that it is simply better to avoid them. The risk of offending someone or being misunderstood is so high that it is more prudent to ignore the subjects altogether. And for almost a century the business world followed her advice. After all, in those days corporate leaders sought to conform to society, whereas contemporary leaders seek to transform society and challenge outdated and discriminatory social norms.

Businesses have typically eschewed involvement in personal or controversial subjects, wanting to protect their brand to avoid offending employees or clients and other stakeholders. So it is logical that, for decades, the corporate world has religiously followed (pun intended) Emily Post's advice that sex, politics, and religion were considered taboo subjects.

D. W. Miller $(\bowtie)$

Princeton University, Princeton, NJ, USA

e-mail: dwm@princeton.edu

(C) The Author(s) 2020

T. Akram and S. Rashid (eds.), Faith, Finance, and Economy, https://doi.org/10.1007/978-3-030-38784-6_9 
However, just because certain subjects are difficult to talk about does not in itself mean one should not try. Indeed, avoiding the discussion of taboos or other awkward subjects such as racism often causes even more problems. Indeed, many leaders and their companies have realized that the greater danger lies in ignoring important topics, regardless of how delicate or awkward they may be. And that one's brand may be harmed, and stakeholders might be upset if the company does not address issues seen as central to human identity and part of creating a diverse and inclusive workplace.

Thus, over the past few decades the three taboos have gradually crumbled, giving way to various strategies to engage and discuss sex, politics, and religion in a corporate context. Today in corporate America, and many other countries around the world, the first two taboos have largely fallen by the wayside. Sex was the first taboo to come out of the closet. Starting with new birth control methods, eventually public discourse about sexuality, sexual orientation, and more recently sexual harassment (e.g., the \#metoo movement) became normative not avoided. Admired companies, whether small or large, have developed thoughtful and specific policies to address questions of sex, including sexual orientation, sexual identity, sexual misconduct, office relationships, and sex-related medical benefits. These matters remain deeply personal and views may differ, but companies realize that to not talk about them and develop specific policies hurts business by affecting, among other things, the attraction and retention of a wider talent pool.

The second taboo, politics, has also gradually fallen. Large companies and industry associations now invest significant resources lobbying regulators and politicians for policies favorable to their industry. Many companies make it a practice of supporting candidates from both political parties so as to hedge their bets for whoever wins. And CEOs are increasingly pressured by their employees to speak out on government policies they disagree with or find offensive, including issues such as immigration, the environment, healthcare, gender, and racism. So discussing politics, while still potentially emotional and divisive has become a normative part of corporate life and conversation.

So what about the third taboo, religion? That is the subject of this chapter. Have companies come to a stage where, like sex and politics, they find business value in engaging the topic? Or is it still best to avoid the topic for fear that it remains too emotive, conflictual, and divisive? 


\section{We're Not in Kansas Anymore: Today's Workplace Context Has Changed}

In the classic 1949 movie, The Wizard of Oz, the lead character Dorothy utters a memorable line. As she is magically transported from her idyllic irenic life in the Midwest to the imaginary land of $\mathrm{Oz}$, with anxiety in her voice she says to her pet dog, "Toto, I have a feeling we're not in Kansas anymore."

One could say the same about virtually every aspect of corporate life today versus even just a few decades ago. We increasingly live and work in a digital, technology-driven economy. Phrases like the gig economy, Industry 4.0, and the like abound. The old boundaries between work and personal life are blurred. At work most white-collar workers take time to tend to personal chores. And when at home they catch up on emails, participate in conference calls, and do other forms of work via various forms of connectivity to their office, clients, and vendors. In addition, whether by choice or necessity, both white- and blue-collar workers frequently change companies and career paths. A job for life with one employer is an anachronism. And while discrimination still exists, women and minority groups are increasingly breaking down workplace barriers and gaining access to the most senior levels of virtually all sectors.

Moreover, employees of all ages, and particularly the Millennial and $\mathrm{Z}$ generations, are no longer content to live a bifurcated life. They want to bring their whole self to work and not leave an essential part of their identity or important aspects of themselves in the parking lot. They do not want to feel ashamed or hide who they are or what they believe. This applies to visible parts of their humanity such as race, ethnicity, gender, and even hairstyle or body art. And this holistic instinct also applies to often hidden or less visible parts of their identity such as gender orientation and faith.

A further change between our times and Dorothy's is language itself. Words have always mattered, but maybe even more so today. The word "religion" has itself become a very loaded term, not just descriptive. Many in the West view religion as a pejorative term, viewing it as judgmental, exclusive, and divisive. They often prefer the term "spirituality" finding it more open, inclusive, and not doctrinal. Yet some people who view themselves as "spiritual but not religious," ironically, have such a similar doctrinal certitude about their worldview that they too, exhibit the same 
judgmentalism toward religious people that they eschew in religious people. To navigate these linguistic tensions, I find it helpful to use the term "faith" as a more neutral term, one which includes both religion and spirituality. After all, one hundred percent of the population have faith. Their faith may not be theistic in nature, but they have faith in something, be it science, reason, or experience. Faith may be theistic or non-theistic. Put another way, we all have a worldview or Weltanschaunng through which we filter our experiences, actions, and beliefs, and how we find meaning and purpose.

For the purposes of this chapter, however, I largely use the term religion in deference to Emily Post's provocative trope we are investigating; whether speaking about religion at work is still taboo. I invite the reader to mentally substitute the word spirituality, worldview, or faith, if that helps follow the logic of this article.

Another driver toward removing the taboo of religion at work is the dramatic changes over the past few decades in the religious profile and practices of the United States workforce. Long gone is any sense of religious homogeneity that conceived of the country as comprised of predominately mainline Protestant Christians or Judeo/Christian in nature and culture. Due to a variety of factors, most notably immigration, the number of Catholic Christians is now $21 \%$ of the population and growing. Evangelical Protestants account for $25 \%$ of the population and black Protestants account for $7 \%$. The number of once culturally dominant mainline Protestants is shrinking and now claim barely $15 \%$ of the population. ${ }^{1}$

Of equal interest is how immigration patterns are causing a rise in nonChristian traditions, including Muslims, Sikhs, Hindus, Buddhists, and others. And finally, research reveals a significant increase in those who self-describe as spiritual-but-not-religious, agnostics, atheists, and the socalled "NONES" (pun intended) who pollsters describe as fitting none of the traditional religious categories. And these significant statistical changes to the religious landscape have almost forced the conversation upon the business world, making it a topic they can no longer avoid or consider taboo. After all, who is going to tell Indra Nooyi (a Hindu), the recently retired CEO of PepsiCo that her religious identity, or that of the vast

\footnotetext{
${ }^{1}$ Pew Research Center, “The Changing Global Religious Landscape” (2017).
} 
number of Hindus and Muslims who work in Silicon Valley that their religious identity is taboo?

Dorothy was right when she said, "Toto, I have a feeling we're not in Kansas anymore."

\section{RESEARCH INTO THE INTERSECTION OF FAITH AND WORK}

Many universities (both private and public) and non-profits are increasingly studying the subject of faith, work, and economics in the context of today's society. My own role, directing Princeton University's Faith \& Work Initiative (FWI) is but one example of many scholarly enterprises studying this phenomenon. FWI's mission is to "conduct research into faith and work, developing theoretical frameworks and practical resources for leaders in the marketplace." This involves interfaith and interdisciplinary thinking. Some of FWI's areas of research include: studying the faith at work movement; researching the nature of work, technology, and labor in the new economy; connecting ancient religious ideas and resources to modern-day marketplace concerns; developing a psychometric scale that reveals how people of all traditions manifest or live out their faith at work; and considering the role of religious traditions as a resource for business ethics.

As noted above, one theme that continually emerges in our research and that of other scholars, is that employees no longer wish or are willing to compartmentalize their life by hiding or shutting down essential parts of their being. For many people their faith, their religious tradition, or their spirituality is an important, if not central, part of their identity and humanity. But what does it mean to "bring your faith to work"? What does faith look like in the workplace? How do people integrate their spirituality and work? Isn't that going to be messy, disruptive, and cause conflict at work?

\section{The Case for "Conflicting Forces"}

It is not without good reason that many in the business world, and other parts of society have historically considered religion as a taboo subject. Let's consider some of those claims and their validity: 
- Religion is divisive-Yes, religion is a topic that can divide its various adherents. There are too many examples of religiously motivated violence, which one fears might spill over into the workplace. In some work contexts people from minority religious traditions are reluctant to voice or practice their faith for fear of discrimination.

Though religion can be divisive, it need not necessarily be divisive. Moreover, it can also, when handled thoughtfully and respectfully, be a uniting force. People of different traditions can often find common ground and mutual respect that they each believe in a divine figure even though their understandings of that may differ. Indeed, other aspects of humanity, such as race and ethnicity can also be divisive. Some might even argue that baseball and football allegiances cultivate even more hatred and violence between adherents of one team or club and another!

But scholars and practitioners rightly argue that those attributes are not prima facia divisive. Indeed, thoughtful companies have figured out how to manage through the potential conflictual issues of race and ethnicity and are now learning to do the same with faith at work.

- Religious accommodation is disruptive to the work environmentmany religious traditions require their adherents to do or not do certain actions. Some are required to pray at precise times during the day. Some are required to wear certain attire (or, conversely, not to wear certain attire). While others are forbidden to touch certain products (e.g. alcohol, pork) or be involved in certain job functions or industry sectors. And yet others might have a desire or religious duty to be absent from work to observe certain holy days or leave work before sundown on their Sabbath. Individually and collectively these and other accommodation issues can conflict with or disrupt workflows, serving customers, and other business needs.

Generally speaking, the legal test is that employers are obligated to accommodate reasonable requests of sincerely held religious beliefs or practices so long as they do not unduly disrupt the business. This rule of thumb is based on Title VII of the Civil Rights Act of 1964, which

prohibits employment discrimination based on religion. This includes refusing to accommodate an employee's sincerely held religious beliefs or practices unless the accommodation would impose an 
undue hardship (more than a minimal burden on operation of the business). A religious practice may be sincerely held by an individual even if newly adopted, not consistently observed, or different from the commonly followed tenets of the individual's religion. https://www.eeoc.gov/eeoc/newsroom/wysk/workplace_ religious_accommodation.cfm

In practical terms, this is a fairly low bar, meaning that companies can legally decline accommodation to requests they deem too disruptive. But the fundamental point is that employers have a legal obligation to at least try to accommodate religious accommodation requests. Many companies have sought to learn more about the accommodation requests and work with employees and groups sharing certain religious requirements to find creative ways to honor the employee request without causing disruption or conflict. Indeed, in a tight labor market, employers who are known to be "faith-friendly" (not to be confused with faith-based) i.e. companies who welcome and embrace people who want to bring their faith to work, become very desirable employers. Both common sense and bottom-line impact are leading enlightened companies to encourage supervisors to find creative solutions to accommodation requests and thereby to attract and retain the best talent.

- Religious harassment-harassment is a serious issue and a legitimate concern in the workplace. It is related to another serious issue known as a "hostile workplace." Workplace harassment can take many forms, including sexual, racial, and religious. Charges of religious harassment emerge when someone might be mocking or disrespecting someone for their religious beliefs, or conversely, being overly zealous trying to persuade someone to become a part of their belief system.

- Proselytizing - while proselytizing is usually considered offensive and inappropriate, many are surprised to learn that strictly speaking, it is not prima fascia illegal. It becomes illegal when the recipient states they do not wish to be the recipient of such overtures and communications. When proselytizing crosses this line, it can be deemed harassment or part of a hostile workplace, and cause for legitimate complaints.

- Quid pro quo-is a form of favoritism or discrimination where a supervisor, for example, might offer a promotion to an employee 
solely on the condition they agree to attend their church or some similar condition.

\section{The Case for “Convergent Resources”}

The above case for "conflicting forces" raises several legitimate and important points. Some of them, when viewed more closely also have a positive side (e.g. accommodation) whereas others are always conflictual and problematic (e.g. harassment). While not trying to minimalize the conflictual issues, we also note that many of these challenges are not unique to religion or faith in the workplace. Harassment, quid pro quo, and other discriminatory practices are not the sole domain of religion. Other topics and issues can also be conflicting forces in the workplace.

So why should religion be singled out as a taboo, whereas other personal and often emotive topics (e.g. gender, sexual orientation, race, and ethnicity) are seen as core parts of company diversity and inclusion (D\&I) programs and are not seen as taboo? Indeed, research and experience suggest that with appropriate education, training, and policies, the potential problems associated with other D\&I categories and groups are manageable if not largely avoidable. Moreover, there is increasing evidence-just as has been demonstrated with other forms of diversity - that faith and work, properly implemented, can bring many positive benefits to employees and the business as a whole.

If that is accurate, what then are some of the possible benefits associated with faith at work? What is the business case for not just tolerating but embracing faith and work as convergent resources? The reasons are many but before presenting them, let me first outline the four typical organizational attitudes toward or ways that companies approach the concept of faith at work ${ }^{2}$ :

- Faith-avoiding-companies that are faith-avoiding attempt to stifle or prevent any manifestation of faith at work, be it verbal, attire, items in their workspace, or use of company property for any gatherings or other uses. They generally view faith at work as conflictual, problematic, inappropriate for a business context, and generally

${ }^{2}$ Miller, D. W. and Ewest, T., "A New Framework for Analyzing Organizational Workplace Religion and Spirituality," Journal of Management, Religion, and Spirituality, Vol. 12, No. 4, 2015, 305-328. 
are unaware of or choose not to follow Title VII laws against religious discrimination at work. Some companies in this faith-avoiding category may simply not think holistically or even know that many employees want to bring their whole selves to work, including their faith.

- Faith-tolerant-companies that are faith-tolerant (or as I call them in the article, "faith-safe") will follow the minimal legal accommodation required by law but avoid full embrace of faith and work as a company policy. My research suggests that most companies today fall in this category. They are not hostile to faith at work as some faith-avoiding companies maybe, but they are reluctant if not afraid to put in place formal policies and practices to welcome this as a new form of D\&I. This reluctance may come from legal guidance or from (somewhat ironically) the chief human resources officer. These companies ascribe to the old adage, "if it ain't broke, why fix it?" The answer, of course, is that it will break someday, and the company may be on the wrong end of a wrongful dismissal or religious harassment lawsuit.

- Faith-based-companies that are faith-based are typically small or medium-sized family or owner-operated businesses who clearly state that their company values and how they conduct business are grounded in a certain religious tradition. Not surprisingly, that tradition is the religious identity of the family or owner. Thus, they strongly embrace faith at work. But they risk causing real or perceived discomfort to if not discrimination against employees or job applicants who do not ascribe to that particular religious tradition. Faith-based companies are not illegal, but if over 10 employees, they must follow the same Title VII guidelines as larger companies.

- Faith-friendly-finally companies that are faith-friendly are different than the other three approaches in several ways. First, they don't avoid or merely tolerate faith at work. Nor do they have a single espoused religious identity. Rather, they embrace faith identities as a whole, welcoming and respecting people of all faith traditions, including worldviews such as atheism and agnosticism. Indeed, all people have a worldview or a "life philosophy," whether structured or informal; something they use as a baseline or a filter for meaning, purpose, ethics, and how to live their life. 
Faith-friendly companies give all people an equal seat at the table, and equal dignity and respect. Faith-friendly companies recognize that conflicts can occur, so they invest in training, education, and having thoughtful policies that help reduce if not avoid conflictual issues that arise from religious motivations.

Some faith-friendly policies and practices are tangible and visible, while others are less tangible or visible. A company might start by creating written faith-friendly policies and including them on their web site and other internal policy materials. These would send a signal and overarching message to management, employees, and applicants that bringing your faith to work is not only okay but embraced. And that as a faith-friendly company they welcome people of all faith traditions, whatever they may be. Other examples of faith-friendly practices include but are not limited to: offering kosher and halal food in company cafeterias or meetings; trying to avoid scheduling major company or client events/meetings during known religious holidays; making conference rooms available for faith groups to meet for study, prayer, or fellowship; creating dedicated meditation or prayer rooms open to all; hosting education events to learn about various religions and their major holidays; and consider having sanctioned religious affinity groups/business resource groups with the same standing and access to resources as women's, LGBTQ+, and other D\&I affinity groups have.

Faith-friendly companies feel it is not only the "right thing to do" to embrace faith as part of D\&I and holistic thought. They also see the potential business and bottom-line benefits accruing from such creating a culture of faith-friendliness.

So what are these benefits that emerge from companies that view faith and work as convergent resources and adopt a posture of faithfriendliness? Here are but a few reasons, all of which are backed up by a growing body of research in the Academy of Management and other scholarly guilds, as well as field research and practical experience:

- Diversity \& Inclusion-most successful and admired companies articulate a strong commitment to D\&I, often citing it as a core value. Companies are quick to point out that not only is this the right thing to do, but it also brings bottom-line business benefits. Research suggests that over time diverse teams outperform homogenous teams, bring innovation, and help improve the attraction and retention of talent. Leading companies across a variety of business 
sectors, such as Deloitte, Accenture, Tyson Foods, and VMware, are also realizing that diversity should not be limited to traditional aspects such as race, ethnicity, gender, and gender orientation, but should also include socio-economic diversity, and idea, religious, and worldview diversity.

- Generational difference and trends-Millennials now constitute over $50 \%$ of the American workforce. ${ }^{3}$ And the new $\mathrm{Z}$ generation is already making its impact. Common to both is an embrace of this expanded view of diversity and inclusion that includes idea, religious, and worldview diversity. The idea of not bringing their whole self to work is inconceivable to them.

- Evidence for and trends toward holistic lifestyles-growing bodies of scholarly research in various guilds, including human resource, psychology, and management overwhelmingly find that treating employees holistically enhances a host of business metrics. This is embodied by the companies who typically appear on "most admired" and "best place to work" lists who have discovered the business benefits of supporting holistic practices. And faith or spirituality at work is one part, and for many people a central part, of living and working holistically.

- Well-being-No longer do companies ignore or stay removed from influencing the personal well-being of their employees. Today, companies realize that healthy employees are better employees. Many companies offer a wide range of personal health benefits, including subsidized (if not free) gym memberships, yoga classes, mental health resources (e.g. Employee Assistance Programs), and smoking cessation programs. Many also offer free programs to stimulate the mind, including professional development opportunities, in-house classes, and subsidized external education opportunities. A logical extension of this commitment to supporting employee well-being is for companies to consider the spiritual well-being of their employees, including developing faith-friendly policies and practices to support employee well-being. Some companies even offer chaplaincy services on workplace premises. Participation in all of these well-being programs is, of course, voluntary.

${ }^{3}$ Pew Research Center, "Millennials Are the Largest Generation in the U.S. Labor Force," http://www.pewresearch.org/fact-tank/2018/04/11/millennials-largestgeneration-us-labor-force/. 
- Links between ethical conduct and ethical foundations-I would never claim that one has to be religious or spiritual to be ethical. That claim is invalidated regularly when we see religious people doing unethical if not illegal activity. Equally, we regularly see nonreligious people who exhibit the highest moral and ethical rectitude. Some would conjecture that the key to being and remaining ethical is to have some sort of moral anchor to help keep one grounded and to have some kind North Star or reference point for guiding ethical decision-making and behavior. For many, this anchor and North Star are religious in nature, while for others it is non-theistic. For those who are engaged in a faith tradition, there is some research that suggests that people who retain close proximity to and engagement in their worship community exhibit deeper commitments to ethical conduct. Drawing on the Aristotelian teaching of habituation, many religious traditions believe that virtuous behavior can be learned and taught by emulating positive role models and the disciplined practice of virtuous behaviors. I have coined the phrase "ethical fitness ${ }^{\mathrm{TM}}$ " as a way to encapsulate that ethical conduct can be practiced and developed in the same way we can cultivate physical fitness through a healthy diet, exercise, and discipline. For many people, the foundation of their ethical fitness is grounded in their faith tradition.

\section{What Does Faith at Work Look like?}

Companies and business leaders might rightly ask, what does faith at work actually look like? How do people "bring" or manifest their faith at work? And some also ask, how do I measure this phenomenon?

With over 20 years of studying these and related questions I have come to several conclusions. Here I will share just three. First, people increasingly want to bring their whole self to work, including their faith. They no longer want to live a bifurcated life, being one person at work and a different one at home. Moreover, they are seeking meaning and purpose in and through their work, not just a paycheck. Two, many who want to do this are not sure how to do it, receiving little guidance from their worship communities or religious leaders. And three, most businesses lack a language and a framework to understand, value, and manage the faith at work phenomenon. 
To help resolve these and related questions, I have developed an instrument to help describe and measure faith and work integration. But before outlining it, it is worth remembering a few contextual realities. First, faith is multidimensional both in what one believes and the many different practices or ways one might manifest and live out those beliefs. This is true within specific faith traditions and between differing ones. Second, there is no one single or typical way of bringing one's faith to work. Moreover, it is not necessarily visible or obvious when someone has brought their faith to work. The stereotype some might conjure up when trying to picture what faith at work looks like is people who have religious bumper stickers or icons by their workspace, wear religious garb, or who talk incessantly about their faith. These stereotypes, like most stereotypes, are grounded in a partial truth but are ultimately unfair and inaccurate caricatures. In my research I seek to go beyond the misleading and incomplete stereotypes of integrating faith and work to discover and paint a much more complete, diverse, and inclusive picture.

Based on empirical research into hundreds of organizations and thousands of people, I have concluded that there are four typical ways that people bring their faith to or manifest their faith at work. I call these the Four Es. And each of the Four Es has two suborientations. My research also suggests that most people have a natural predisposition (whether conscious or subconscious) to accent one of the Four Es or their underlying suborientations. These manifestations are found in most major faith traditions. And prescriptively, I would argue that all of these manifestations have valid theological underpinnings.

I call this framework or typology "The Integration Profile ("TIP") Faith and Work Integration Scale" or TIP for short. ${ }^{4}$ Building from my original theoretical model in God at Work: The History and Promise of the Faith at Work Movement, ${ }^{5}$ and with the help of gifted colleagues Tim Ewest, Mitch Neubert, and Nicoleta Acatrinei (each of whom contributed expertise in psychometric scale development), we have developed this instrument called TIP. It allows people of any faith tradition to learn what their natural faith/work integration tendencies are and the relative strength of or lack of focus they have on each of the Four Es.

${ }^{4}$ Miller, D. W., Ewest, T., and Neubert, M., "Development of the Integration Profile (TIP) Faith and Work Integration Scale," Journal of Business Ethics, January 2018, 1-17.

${ }^{5}$ Miller, David W., God at Work: The History and Promise of the Faith at Work Movement (New York: Oxford University Press, 2007), 220pp. 
We are find that individuals, companies, and even congregations are interested in using TIP as a way to understand themselves and others better. Organizations are particularly interested in their aggregate profile and want to conduct further research to see if any TIP variables have salience and impact on other important business metrics such as engagement, satisfaction, ethics, meaning, purpose, client service, etc. It is too soon to tell if there are any generalizable patterns or possible correlations, what differences might exist between the for-profit and non-profit sectors, and what distinctions might exist between international data sets or faith traditions. Dr. Acatrinei and I are currently gathering international data sets and exploring these and other related questions.

Here is a brief description of TIP's Four Es and their suborientations, i.e. the eight overall ways people manifest their faith at work:

- Ethics - those in the Ethics profile tend to live out their faith at work with a focus on ethics, as informed by or grounded in the teachings of their faith or worldview. For some, this means a suborientation focus on personal ethics and behavior, and on one's own conduct (e.g. not cheating on expenses or lying to a client). This often involves the intentional cultivation of "ethical fitness." This is a term I have coined that implies dedication to developing disciplines, habits, and preparation to have readiness for ethical situations, in the same way that athletes develop physical fitness to prepare for competitive events. For others in the Ethics profile the suborientation focus is on social ethics, i.e., the larger ethical impact of their organization's products and services on their clients and wider society (e.g. do our products cause injury to people or harm the environment?).

- Experience-those in this profile want to experience meaning and purpose in their work. They want work to be more than a paycheck. Their faith helps them experience their work as a calling, having spiritual value and significance. For some, the suborientation focus is on the intrinsic nature of the work itself that feels like a calling (e.g. being a master craftsman, writing beautiful code, mowing a lawn perfectly, diagnosing a medical problem). For others, the suborientation is not the job task itself that brings them meaning per se, but they experience delight in being part, however small, of the overall process that made the end product or service (e.g. working on factory line but knowing your company makes safe, affordable, high quality food products or cars to help others live a better life). Notably, to 
experience work as a calling (whether in the job function itself or being proud of the end product) does not require the work to be highly remunerative or of a high social standing. Executives, doctors, and lawyers, as well as hourly workers, check-out clerks, and cab drivers can all experience meaning and purpose in or through their work.

- Expression-those who are drawn toward the Expression profile as the way they manifest their faith at work often feel a desire or in some cases a religious duty to express their faith at work. For some, the suborientation focus means verbal expression where talking about and sharing their faith with others is important. While for others, the suborientation focus is an accent on non-verbal means of expressing their faith. This expression could involve wearing specific attire (e.g. a cross, yarmulke, headscarf) or displaying a symbolic object in their workplace (e.g. a Bible, a statue of the Buddha, or a dreamcatcher).

- Enrichment-people who are drawn to the Enrichment profile tend to focus on the ways their faith helps them practice and cultivate inner growth and strength in times of workplace challenges, pressure, or stress. This manifests itself in regular prayer disciplines, devotional practices, and contemplative disciplines that tend to the inner soul, helping to heal and strengthen. For some, their Enrichment suborientation practices are very private and done by alone themselves, perhaps early in the morning before work, or quietly in their office or somewhere at their place of work. For others, their suborientation prefers sharing and finding comfort in community, and engaging their Enrichment practices in a group with others.

\section{CONCLUSION}

We started this chapter pondering whether Emily Post's so-called three taboos at work-not talking about sex, politics, or religion-should still be the norm in business today, with a particular interest in the taboo on religion. We quickly observed that discussing, thinking about, and developing corporate policies around sex and politics are normative today. So, we probed the third taboo, religion. Dorothy helped us realize that we are not in Kansas anymore. Today's workplace context has changed; we no longer live in the business world of 1922 like Emily Post. And as regards religion no longer being a taboo at work, we asked, is that a good thing? 
We made a case for faith and work as conflicting forces and as converging resources. As part of this, we introduced a framework for analyzing the four typical ways companies address the phenomenon of faith at work, ranging from trying to stifle it to embracing it.

I concluded that publicly traded and other larger companies who embrace faith-friendly policies and practices will find it beneficial to employees themselves and to the company's bottom line. And finally, we addressed a simple but not-so-simple question, what does faith at work look like? Here I introduced The Integration Profile Faith and Work Integration Scale, more commonly known as TIP, to help provide a language and framework to talk about faith, religion, and spirituality in nonemotive, respectful, informative ways, and constructive ways.

Time will tell whether conflictual forces of the world will insist religion is still a taboo topic in the work world. Or will companies discover and embrace that, done in a faith-friendly way, faith and work are indeed convergent resources. To be continued...

\section{BIBLIOGRAPHY}

Miller, David W. God at Work: The History and Promise of the Faith at Work Movement, 220p. New York: Oxford University Press, 2007.

Miller, D. W., T. Ewest, and M. Neubert. "Development of the Integration Profile (TIP) Faith and Work Integration Scale." Journal of Business Ethics (2018), 1-17.

Miller, D. W., and T. Ewest. "A New Framework for Analyzing Organizational Workplace Religion and Spirituality." Journal of Management, Religion, and Spirituality, 12, no. 4(2015): 305-328.

Pew Research Center. "The Changing Global Religious Landscape" (2017).

Pew Research Center. "Millennials Are the Largest Generation in the U.S. Labor Force" (2018). http://www.pewresearch.org/fact-tank/2018/04/ 11/millennials-largest-generation-us-labor-force/. 
Open Access This chapter is licensed under the terms of the Creative Commons Attribution 4.0 International License (http://creativecommons.org/licenses/ by $/ 4.0 /$ ), which permits use, sharing, adaptation, distribution and reproduction in any medium or format, as long as you give appropriate credit to the original author(s) and the source, provide a link to the Creative Commons license and indicate if changes were made.

The images or other third party material in this chapter are included in the chapter's Creative Commons license, unless indicated otherwise in a credit line to the material. If material is not included in the chapter's Creative Commons license and your intended use is not permitted by statutory regulation or exceeds the permitted use, you will need to obtain permission directly from the copyright holder.

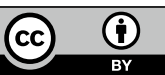




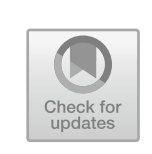

\title{
The Moral Ecology of Good Wealth
}

\author{
Michael Naughton
}

What is good wealth? What are its sources? What logic helps us toward its created potential? What practices define and sustain its goodness? And, to the contrary, how does wealth go bad? What are its disorders? And what logic seduces us to create bad wealth?

To get at these important questions, we need to avoid the all too often prideful and relativistic response that gives a morally and spiritual deprived answer: "I get to decide what is good." "It is my decision." "I earned it, and so I control my wealth." People of wealth who think they are the source of their wealth suffer from deadly capital vices and in particular from acedia (Greek akedia, a (absence) + kedos (care), not caring about caring, indifference) a spiritual laziness that fails to get to the root of reality.

A fruitful approach to a vision of "good wealth" is to see the interdependent and organic relationship among wealth's creation, distribution and charitable dimensions. The relationship among these three stages of wealth fits well with what Catholic social teaching refer to as "moral ecology," where we see and act on the profound interconnected dimensions of what good wealth is in terms of a good life and a good institution.

\footnotetext{
M. Naughton $(\varangle)$

University of St. Thomas, St Paul, MN, USA

e-mail: mjnaughton@stthomas.edu

(C) The Author(s) 2020

T. Akram and S. Rashid (eds.), Faith, Finance, and Economy, https://doi.org/10.1007/978-3-030-38784-6_10
} 
Within this moral ecology, we can also begin to see our blind spots not in a judgmental moralistic way, but in a way of humility of receiving the deeper truths of our humanity.

Where I want to begin in this approach is with institutions and in particular with business as an institution. Some of the biggest debates we face as a country is over how we understand the purpose of the institutions we live in and in particular the goods such institutions should strive for. This is no small matter. One of the most significant responsibilities of leaders in any organization is to articulate, cultivate and execute the purpose of the institution they lead. What the purpose question does for an institution is that it clarifies what goods are to be pursued by an institution and how it orders such goods for the good of the whole. This has massive implications for the quality of the society we live in. It is precisely such purposes that give institutions meaning as well as legitimacy in the communities where they reside.

The pursuit and articulation of institutional purpose is not as easy or as direct as it may seem, however. One challenge is the significant cultural debate over the institutional purposes of business and the goods it should promote, universities and education in general, family and the meaning of marriage, religion and whether it is good for society, government and health care. Because of the increasing pluralism of society, we have difficulty agreeing to a common understanding of the good-the common good, so our tendency is to go to the least debatable "thin" approach to the good. This move toward a "least common denominator," unfortunately, "flattens" or "dilutes" the good of institutions by reducing them from a vibrant set of integrated goods to one emotive or instrumental good-business to shareholder wealth maximization; universities to career credentialing; religion to emotive experience; marriage to sentiment between autonomous individuals; and so forth.

In this paper, I want to focus on the institution of business as a way at getting at what we mean by "good wealth." In one sense, much of the economic wealth generated in this country comes from business and consequently its distribution and charity, and if we are to examine what is "good wealth" we need to engage business. But first we need to ask the larger question: what is the good business does? ? $^{1}$ The document Vocation of the Business Leader produced by the Vatican's Pontifical Council for

${ }^{1}$ See Robert Kennedy, The Good That Business Does (Acton Institute, 2006). 
Justice and Peace (now called the Dicastery for the Promotion of Integral Human Development) speaks about three goods business contributes to the common good of society ${ }^{2}$ :

- Good Goods: Making goods that are truly good and services that truly serve;

- Good Work: Organizing work in which employees develop their gifts and talents so as to serve the larger community; and

- Good Wealth: Creating sustainable wealth so that it can be distributed justly to the institution's contributors.

Business is a goods producing institution. When all three goods are present, business contributes positively to the social conditions that make it "easier" to foster integral human development-the flourishing of persons and communities. This is what the Catholic social tradition defines as the common good.

In this paper, I focus on the meaning of "good wealth" keeping in mind the interrelated dimensions of the other two goods of businessgood goods and good work. I want to focus on what I will call the three interdependent dimensions of good wealth: (1) stewardship-wealth creation, (2) justice - wealth distribution and (3) charity-wealth dispersion. To understand the relationship of these three dimensions and their importance, a quick glance at one of the great business leaders in United States history, Andrew Carnegie, can be helpful in orienting us to the issues we need to face.

In terms of wealth creation, Carnegie was one of the great entrepreneurial immigrants the US has seen. He went from doing modest low-level organizational tasks to becoming one of the great American industrialists of the nineteenth and early twentieth century. As an immigrant who was a "capable, energetic, ambitious, discontented man," he built the Carnegie Steel Corporation into the largest steel manufacturing company in the world. Influenced by the social Darwinist Herbert

${ }^{2}$ Vocation of the Business Leader (Vatican City: Pontifical Council for Justice and Peace, 2014). https://www.stthomas.edu/media/catholicstudies/center/ryan/publications/ publicationpdfs/vocationofthebusinessleaderpdf/PontificalCouncil_4.pdf. I find the language of "goods" to be an important language of business. As Lewis explains "Goods are ends just in so far as they serve to perfect." See V. Bradley Lewis, "Is the Common Good and Ensemble of Conditions," Archivio di Filosofia, LXXXIV, 1-2 (2016), 130. 
Spencer and other thinkers such as William Graham Sumner (although how Carnegie' Presbyterian upbringing connects and does not connect to the Darwinian influence is beyond this paper) as well as by the highly competitive businesses he worked in, Carnegie viewed business in terms of the logic of the market. The logic of the market presupposes that nothing is given, that things are only acquired and we wrestle out of nature her fruits.

In terms of distribution, Carnegie was given the name "robber baron" along with other American industrialists, such as Rockefeller, Vanderbilt and Gould. Influence by the Darwinian principle of the survival of the fittest, Carnegie unethically crushed competitors, bribed government officials and broke unions. A defender of laissez-faire economics, he drove costs down including labor costs. This led to sub-living wages and poor conditions, hostility to unions, resistance to government regulation except when it protected his firm, and a fundamental allergic reaction to justice and equity. He actually believed that the concentration of capital was necessary for societal progress by those who knew how to create wealth. For Carnegie, unions for example, impeded the evolutionary progress of the market by "unnaturally" pushing up the cost of business and protecting the narrow interests of labor.

In terms of charity, Carnegie famously wrote he "who dies rich, dies disgraced." He saw himself as well as others with resources as trustees of their wealth who should live without extravagance, provide moderately for their families, and use their riches to promote the welfare and happiness of others.

There is much to admire about Andrew Carnegie as well as many other entrepreneurs and business people who work hard and give much. His virtues of personal frugality, sacrifice and hard work are essential for good business. But like all of us, they have significant blind spots. For Carnegie, he saw little inconsistency between how he distributed his wealth and how he created it as well as gave it away. The point here is not to condemn Carnegie. There is way too much condemning of historical figures from the modern perch. But good qualities become polluted when businesspeople discount one of the important functions of good wealth such as its distributive function. And it should be noted that there are many blind spots in discerning good wealth, such as those social justice warriors who denigrate charity and who only see justice in terms of the regulations of the state. Or companies that create harmful products such as pornography 
or tobacco, yet, justify their firms because they pay just wages and taxes. Good wealth entails a moral ecology where all three functions are interconnected. When one function is in disorder, the whole is disordered. This paper explores in detail the three functions of good wealth and their ordered interconnections.

\section{Wealth Creation: Stewardship}

In terms of wealth creation, business enterprises are the economic engine of society. As a creator of products and services (good goods) and jobs (good work), business must exercise the stewardship of resources in a way that it creates more than what it has been given. ${ }^{3}$ Good stewards of wealth are those who do not only take from creation's abundance, but they contribute to it. In business, this stewardship demands a great deal of frugality and economic discipline, tracking carefully costs and revenue, driving out waste, improving production processes, delivering on time, enhancing quality, and so forth.

When a business generates more than what has been given to it, we call it profit or margin, a surplus of retained earnings over expenses. This profit enables a company to sustain itself into the future. Profits wisely used over time create equity in companies, which strengthens the firm's wealth generating capacities to build for the future. A business with a healthy balance sheet, for example, simply has greater abilities to build a future than those laden with debt. It can handle the unexpected downturns of the economy. A profitable business creates the conditions for well-paying jobs, opportunities for employee development, useful products and services, satisfied customers, and vibrant communities.

Yet, profit is like food. You need it to be healthy and sustainable, but you ought not to live for it. It is a means not an end, a reward not a motive (which is why so many executive incentive programs can be so destructive). Profit makes a good servant, but a lousy master.

When profit becomes the master, however, businesses often ignore or discount what have been given. The two most significant gifts they receive and co-create with are nature and family. If they fail to recognize these gifts, crisis usually follows. Take for example nature. The most basic gift we inherit is nature. Without the goods of creation, we are bankrupt.

${ }^{3}$ Matthew 25:14-30. 
We have become increasingly aware, although not as fast as we should, of the demands of the proper stewardship and use of the environment. The book of Genesis tells us, to "till and keep" creation, but we have tended to "till too much and keep too little." 4 The importance of recycling, reducing carbon and driving out waste, recognizes our dependence upon nature. Of course, nature does not give its wealth without human work and its distinctive human qualities of creativity and ingenuity. Yet, while the wealth of our economy is increasingly coming from the knowledge of workers, businesses will always be beholden to the gift of nature and of the land.

The other great gift that business receives that enables it to function is the family. When we praise leaders for their work ethic, we are often indirectly praising their parents. We stand on the shoulders of our families who have done far more than we know to get us to where we work and live. If a business is morally sound it is often because the families of those who inhabit the business are morally sound. What marriage and family do for people is they provide the social conditions for people to develop. Family is a primary institution that fosters the common good. They provide what the sociologist Robert Putnam calls "social capital." They create enduring relationships that mutually support its members especially during difficult and trying times. They bond people together. They create the capacity for people to make sacrifices. And despite all their challenges, they create the stability that supports political and educational institutions all of which feeds into the possibility of an economic system. Yet, as several scholars have noted, family structure is too often ignored or discounted when speaking about the economic health of society and in particular business. 5

There are other gifts that businesspeople receive that contribute to their ability to create wealth such as good laws and government. Would a Steve Jobs have been able to flourish in North Korea, probably not. Government plays an important role in establishing just taxes,

\footnotetext{
${ }^{4}$ Cardinal Peter Turkson, "Protect the Earth, Dignify Humanity: The Moral Dimensions of Climate Change and Sustainable Development", delivered at Vatican City, April 28, 2015, http://www.casinapioiv.va/content/dam/accademia/pdf/turkson.pdf. Accessed August 21, 2018.

${ }^{5}$ See the work of Charles Murray, Coming Apart: The State of White America, 19602010 (New York, NY: Crown Forum, 2012).
} 
reasonable regulation and healthy incentives to foster wealth creation. For example, many of the new jobs, which are critical to a healthy business sector, usually come, not from well-established companies, but from entrepreneurial start-ups, small and medium-sized companies, especially family businesses. ${ }^{6} \mathrm{New}$ businesses need entrepreneurs who are willing to take risks, who have faith in the future, who have access to credit and who can operate in a reasonable regulatory environment. Good government will make all these opportunities to create wealth easier and more likely.

\section{Wealth Distribution: Justice AND Right RELATIONSHips}

Wealth creation, however, is only one side of the proverbial wealth coin. We also need to speak of wealth distribution, and in particular a just distribution. So, without profit a company dies, but without justice and a just distribution of wealth a business is organized robbery. ${ }^{7}$ This is seen in price gouging and fixing, monopolies, hoarding benefits and incentives to executive leadership, shifting costs onto the poor and future generations, refusal to pay suppliers or unreasonable extension of payments, corporate welfare and wage theft, and the list goes on.

Precisely because of the abuse of business in relation to its duty to justly distribute wealth, too often, however, a just distribution of resources is seen as only a political function. While the state plays an important role through regulations and taxation in distributing wealth, the role of business as a distributor of justice cannot be ignored. What business, like any institution, must address is how it establishes "right relationships," which

\footnotetext{
${ }^{6}$ http://sbecouncil.org/about-us/facts-and-data/. Accessed August 21, 2018.

${ }^{7}$ One of the serious moral debates we are having in our society is whether there is a "just distribution" of resources. A recent Pew Study rank of concerns for Americans placed "income inequality" as the number one concern on the list they had (higher \% of democrats; lower $\%$ of republicans). This debate is a perennial one. There are few people in this world who would argue for an equal distribution of income, recognizing that an unequal distribution of wealth can be morally legitimate. There are also few people who would justify the current patterns of wealth distribution as morally sound and legitimate. An important question for us is when does inequality of income and wealth become immoral and unjust? One dimension of the debate is where does one focus: wealth creation or wealth distribution.
} 
is at the heart of justice. The Latin root of justice is ius, which means "right," and in particular "right relationships." In Hebrew mišpāt (justice) and şĕd $\bar{a} q \hat{a}$ (righteous) in the Old Testament describe the fulfillment of responsibilities between employer and employee and ruler and people, as well as God and his people, husband and wife and parent and child.

The key to this right relationship in business is the way wealth is distributed. Pius XII made the analogy of wealth being like blood in the human body, it needs to circulate to all the parts in order to make the whole healthy. ${ }^{8}$ Good wealth depends upon not only its creation but also a just distribution; where there is a concentration of wealth, there is most likely clotting causing disease. Business plays an essential role in creating a just distribution of wealth that both generates authentic prosperity and alleviates debilitating poverty. When excessive inequality, greater distance between rich and poor, exceed certain thresholds, regions and countries become ripe for increasing distrust, alienation, violence, crime and possible revolution. Business plays an essential role in creating a just distribution of wealth that both generates authentic prosperity, fosters right relationships and mitigates economic inequities.

As it relates to business, a just distribution calls for wealth to be allocated in a way that creates "right relationships" with those who have participated in the creation of such wealth. This virtue raises a set of knotty and enduring moral challenges for business leaders. Among other things, businesses need to discern and account for the moral implications of how they allocate resources to employees (a just wage and compensation as well as possibilities of employee ownership), customers (just prices), owners (fair returns), suppliers (just prices and fair terms on receivables), government (just tax payments) and the larger community and especially the poor (philanthropy). ${ }^{9}$

${ }^{8}$ Pius XII, Letter Dilecti filii to the German Bishops, October 18, 1949; quoted in Jean-Yves Calvez and Jacques Perrin, The Church and Social Justice: The Social Teachings of the Popes from Leo XIII to Pius XII (Chicago: Henry Regnery, 1961), 149.

${ }^{9}$ These issues raise the moral debate today about rising inequality. While there are many dimensions to this issue, in the United States one particular element is the allocation of historically high profit margins to capital and away from labor. Shareholders and those representing shareholders and in particular senior management saw their incomes rise faster than labor since the 1990s; whereas labor rates have stalled. The reasons for this are complex and varied: globalization, technology, financialization of the economy, decline of unions, deregulation as well regulation of corporate benefits (Washington/Wall 
One of the most significant, although certainly not the only, ways businesses address wealth distribution is whether they pay a "just wage." The just wage is a complex topic, but its importance in a just distribution cannot be underestimated. When an employer receives work from an employee, both participate not only in an economic exchange, but also in a relationship that is both institutional and personal. This relationship, if it is to be just, has three convictions that should guide the distribution of wealth: need, contribution and order.

- Need: For a relationship to flourish in business, an employer must recognize that employees, by their labor, "surrender" their time and energy and cannot use them for another purpose. A living wage, then, is the minimum amount due to every independent wage earner by the mere fact that he or she is a human being with a life to maintain and a family to support. A wage that fails to meet the needs of an employee (in particular a full-time adult) is a wage that will struggle to carry the weight of a real relationship.

- Contribution: While the principle of need is necessary for determining a just wage, on its own it is insufficient, since it only accounts for the consumptive needs of employees and does not factor in their productive contributions to the organization. Because of effort and sacrifice as well as skill, education, experience, scarcity of talent and decision-making ability, some employees contribute more to the organization than others, and are due to more pay. An equitable wage, then, is the contribution of an employee's productivity and effort within the context of the existing amount of profits and resources of the organization.

Street collaborations), etc. The temptation here, however, is to reduce wealth distribution to merely impersonal forces that need to be technically managed either by greater deregulation of the market so as to expand the pie or by greater government regulation to more justly distribute the pie. While market or government solutions are important, businesses and their leaders need to bring to the table a more robust set of principles in how wealth is distributed within the organization in a way that is sustainable in a market economy. One such solution is to find ways to broaden the ownership of capital so that more people participate in its benefits-cooperatives and employee stock ownership plans (ESOPs) are two such forms. Building up ways in which the poor can have wealth increases their chances of moving and staying out of poverty more than only having them depend upon income generation (see James P. Bailey, Rethinking Poverty, Income, Assets and the Catholic Social Justice Tradition [Notre Dame, IN: University of Notre Dame Press, 2010]). 
- Order: Pay is not only income for the worker, but it is also a cost to the employer, a cost that impacts significantly the economic order of the organization. Without proper evaluation of the way a living and equitable wage will affect the economic order of an organization, the notion of a just wage becomes no more than a high-sounding moralistic impracticality. A sustainable wage, then, is the organization's ability to pay wages that are sustainable for the economic bealth of the organization as a whole.

What makes a just wage complex and difficult is that these three convictions are often in tension with others. For example, a tension can exist between the principle of need and the principle of order. Raising wages to a livable level especially for those jobs that are unskilled can put the economic sustainability of a business at risk. The key to resolving the tension is by invoking the principle of contribution. Three conditions of relationship are necessary to come to a fruitful resolution. What business leaders resist is the all too common attitude of passively delegating their responsibilities simply to the mechanical force of labor markets. As managers they are moral agents, distributors of justice, not mere market technicians.

Yet, we need to be clear here that businesses are not responsible to pay employees more than a sustainable wage (a wage consistent with the sound financial management of the firm), even if that wage falls below a living wage. To do so would unjustly place businesses-and all the firm's employees - at risk of economic failure. In a market economy, no organization can be obligated to pay without regard to labor costs' effect on its competitive position, since that would amount to an imprudent choice, leading possibly to economic failure for the business. To "impose justice" in this manner is doomed to long-term failure.

\section{Wealth Dispersion: Charity and the Logic of Gift}

The charitable function of wealth is in many respects the most excellent of the three functions of wealth, since it is in the charitable function that we get at the underlying logic of gift that defines for us what "good wealth" is. It is also the logic of gift that has power to order the logics of the market (incentives) and the contract (rules and procedures) and prevent their disordering practices.

Unfortunately, charity has received such a bad name, in part because of people like Carnegie and others whose charitable giving off the backs 
of labor taints the charity. The lawyer, for example, who does mergers and acquisitions during the day that leads to layoffs and then does pro bono work in the evening for women who have been beaten by their laid-off husbands should at least create an unease of the justice of work and charity of volunteering.

This tension and even contradiction between justice and charity has created a long line of critics of charity who are concerned that charity is used as a substitute for justice. They characterize charity as paternalistic by combining pity with power creating relationships of the giver as superior and the receiver as inferior. Such criticisms are real and have legitimate validity. Unfortunately, they often dismiss charity and fail to recognize its power. In doing so they sever themselves from the power of charity, and when they do, their justice grows cold. What is needed here is a robust notion of charity that complements and fulfills justice.

The problem with charity is not that there is too much of it but too little. "There is little justice in the world because there is little charity in the world and there is little charity in the world because there is little God in the world." 10 Charity goes beyond justice, but it never lacks justice. The two are inseparable from each other and when they are disconnected both are damaged. Pope Benedict put it this way:

On the one hand, charity demands justice: recognition and respect for the legitimate rights of individuals and peoples. It strives to build the earthly city according to law and justice. On the other hand, charity transcends justice and completes it in the logic of giving and forgiving. The eartbly city is promoted not merely by relationships of rights and duties, but to an even greater and more fundamental extent by relationships of gratuitousness, mercy and communion. Charity always manifests God's love in human relationships as well, it gives theological and salvific value to all commitment for justice in the world.

What charity should always help us to understand is, that we have first been gifted so much in life and that our giving needs to reflect the gift that has been received. As Jesus states "From everyone who has been given much, much will be demanded; and from the one who has been entrusted with much, much more will be asked" (Lk 12:48). Ultimately,

${ }^{10}$ From the Introduction by Peter J. Howard in Fulton Sheen, Justice and Charity (TAN Books, 2016), 3. 
one of the principal failures of mainstream business theory and practice is to see capital as a form of property that has a social and spiritual nature, and labor as a form of work that has moral and spiritual meaning. Without this idea of gift and where it comes form and who gives the gift, business will always be prone to utility maximization based on individual interests.

Josef Pieper argued that the key to the moral and spiritual crisis of modern society is the refusal to accept such a gift. He explained that there is "the strange propensity toward hardship that is engraved into the face of our contemporaries as a distinct expectation of suffering." $11 \mathrm{He}$ asks whether this propensity toward work, toward career, toward achievement, toward technology is perhaps the deepest reason for the "refusal to accept a gift, no matter where it comes from?" 12 Have we lost the ability to receive gifts? Are we unable to think with a logic of gift? Have we deluded ourselves into thinking that everything is acquired, earned and achieved? ${ }^{\text {13 }}$

Benedict as well as Pieper are getting at this modern problem by helping us to see how this dynamic between receiving and giving must be informed by charity. Benedict defines charity as "love received and given." 14 The phrase is the beginning of what we mean by a "logic of gift." This logic of receiving and giving is like the inhaling and exhaling of life. It begins to describe the dynamic relationship between the contemplative and active life within the person, which informs the nature of relationships that are first and foremost expressed in family and faith communities, but also informs work communities. Before addressing the issues in relation to current business thinking, I want to highlight three particular claims that this dynamic and complex operation of receiving and giving brings with it, and how these claims inform how we understand the business through a logic of gift.

${ }^{11}$ Josef Pieper, An Anthology, 138. See Leisure the Basis of Culture (South Bend, IN: St. Augustine's Press, 1998), 19.

12 Josef Pieper, An Anthology, 139. See also Jacques Godbout's discussion of the premises of Alcoholics Anonymous, namely, that the alcoholic "cannot solve his or her problem alone, and must recognize that the capacity to find a solution comes from outside, from a gift bestowed by a superior force" (The World of the Gift [Montreal: McGill-Queen's University Press, 1998], 69).

${ }^{13}$ See Pieper Leisure the Basis of Culture, chapter II. Pieper sees this inability to receive as both an ethical and epistemological problem. He explains that Kant's notion of knowledge work plays a destructive role in this significant problem of not receiving.

${ }^{14}$ Caritas in veritate, 5 . 
The first claim is that love as a dynamism of receiving and giving strikes at the heart of how we develop as persons. In the first sentence of his encyclical, Caritas in Veritate, Benedict explains that this charity "is the principal driving force behind the authentic development of every person and of all humanity." 15 These two fundamental dimensions of our lives, of receiving and giving, of contemplation and action, of rest and work are not simply two isolated periods of time in human life, but rather they are, as Karl Rahner S.J. explains, "moments in a person's self-realization which exist only in their relation with one another and are the primary constituents of human existence itself." 16 The point here is that love is not only an act of giving but also receiving and this act of receptivity, of rest, contemplation, prayer, worship plays an essential role in the integral development of the person. This will be explained in more detail in the next two sections.

The second claim, which is of critical importance to highlight in our current situation is that the receiving dimension of this charity has a certain primacy. The structure of this love "expresses the primacy of acceptance over action, over one's achievement." 17 David Schindler expresses this well: "When we first experience our being as created, as being gifted life, this receiving enables us to see our doing and having ... as ways of giving which they are meant to be." 18 This is why Benedict, as Cardinal Ratzinger, states that the person "comes in the profoundest sense to himself not through what he does but through what he accepts," not through what he achieves but what he receives. ${ }^{19}$

The third claim, which builds upon the prior two claims, is that if this deep receptivity fails to animate organizational life, that place where we give of ourselves, we will find ourselves in a disordered relationship in every exchange. This is why Benedict explains that " $[t]$ he great challenge before us ... is to demonstrate, in thinking and behavior ... that in commercial relationships the principle of gratuitousness and the logic of gift

15 Caritas in veritate, 1.

${ }^{16}$ Karl Rahner, "Theological Remarks on the Problem of Leisure," Theological Investigations, vol. IV. trans. Kevin Smyth (Baltimore: Helicon Press, 1966), 379.

${ }^{17}$ Joseph Ratzinger, Introduction to Christianity, trans. J.R. Foster (San Francisco: Ignatius Press, 1990), 266.

${ }^{18}$ David Schindler, "Christology and the Imago Dei: Interpreting Gaudium et spes," Communio 23 (Spring 1996): 159.

${ }^{19}$ Joseph Ratzinger, Introduction to Christianity, 266. See also Caritas in veritate, 52. 
as an expression of fraternity can and must find their place within normal economic activity." 20 It is actually this logic of gift that illuminates the blind spots of businesses creation and distribution.

Charity "makes room" and provides space for a "logic of gift" that orients people in business to deeper levels of communion, solidarity and fraternity. ${ }^{21}$ When charity and its logic of gift is muted or discounted certain distortions begin to seep into the creative and distributive functions of Wealth. In terms of the creative function, the businessperson is tempted to see only their achievement of wealth creation in terms of their own effort. The term wealth creation, however, is a bit of a misnomer since we as humans never really create anything, but what we do is transform what has already been given. Only God creates ex niliho, "out of nothing." Everything that we have is gift. We simply utilize in creative and innovative ways what has already been given. In our creativity, we reflect the image of the creator God we have been made in.

One interesting practice that embodies this charity in business is corporate giving. This activity has a particularly long tradition in the state of Minnesota. Many know that the Target Corporation donates approximately $5 \%$ of its pretax operating profit and is consistently ranked as one of the most philanthropic companies in the US. What some may not know is where this tradition comes from, which moves us to the virtue of charity.

Target's original impulse for this practice started with its founders in the nineteenth century, and in particular George Draper Dayton who wrote "there's a divinity that shapes our lives" and for whom tithing part of his profits for the poor was a biblical command and not a corporate strategy for public relations to generate greater profit. ${ }^{22}$ Influenced by the biblical vision of the world and his Presbyterian upbringing, the fruits

\section{${ }^{20}$ Caritas in veritate, 36.}

${ }^{21}$ Caritas in veritate, 34, 37. "Space also needs to be created within the market for economic activity carried out by subjects who freely choose to act according to principles other than those of pure profit, without sacrificing the production of economic value in the process. The many economic entities that draw their origin from religious and lay initiatives demonstrate that this is concretely possible" (37). See for example the companies associated with the Economy of Communion, family businesses, cooperatives, entrepreneurial ventures, and other types of firms inspired by faith, etc. These communities of persons are not without their contracts and economic rationality, but these realities do not exhaust the meaning of such communities.

${ }^{22}$ Wilfred Bockelman, Culture of Corporate Citizenship: Minnesota's Business Legacy for the Global Future (Lakeville: Galde Press, 2000), 34. 
of his work were not his own but God's and the implication was that part of those fruits went to the poor. Dayton's self-understanding was grounded in a profound notion of wealth that had spiritual and moral claims to it.

The founders of Reell Precision Manufacturing had a similar conviction and they also tithe their profits at $10 \%$ of pretax earnings. Several years ago Reell established a yearly service trip to the Dominican Republic (DR) working with a local church and a local Dominican couple to establish a campus with a school dining hall, playground and chapel. Every February for the past six years, approximately 15-20 coworkers spend a week in the DR. There is much to say about the program, but I want to highlight the logic that drives it and the collateral goodness that comes from it that impacts in a powerful way the creative and distributive functions within Reell. ${ }^{23}$

First, for Reell, the $10 \%$ of pretax profits are not spent because the leadership team thinks such spending will generate ever greater profitability or greater retention or some other instrumental benefit. It is done out of principle of the tithe, which states that the first fruits are given to those who go without. While some companies may give to charities out of a purely instrumental rationale, such instrumental thinking will often eventually do damage to the actions. Such calculated rationality pollutes the act even though the act will have great benefits. T. S. Eliot once put it "The greatest treason is to do the right deed for the wrong reason." While few of us ever have completely pure intentions, our motives matter, especially over time, and they either move to a more narrowly self-focused quid pro quo exchange or they move to a more generous openness to the other.

Second, serving the poor together in the DR has served as a school of servant leadership. When board members, the CEO, mid-level managers and assembly line persons are working side by side digging ditches, visiting homes of local Dominicans, hearing about their situations and then reflecting upon their experiences, they immerse themselves in a situation that increases the chances to touch the heart. Servant leadership as an abstract principle is often difficult to understand in words. It needs to be experienced in order to be understood.

${ }^{23}$ See Michael Naughton and David Specht, Leading Wisely in Difficult Times: Three Cases on Faith and Work (co-author David Specht), Paulist Press, Fall 2011. For full disclosure, I am the chairman of the board of directors for Reell. 
Third, there is always a collateral goodness to tithing, although the exact nature of that goodness can be unexpected. As John Henry Newman put it, "the good is always useful but the useful is not always good." The collateral goodness of the trip has had a positive impact on the culture of the organization in multiple ways. In particular it has brought unity to longer tenured members of the company with newer coworkers. With new leadership in the company, there were longer tenured coworkers who felt that leadership did not "get" the mission of the company. The trip brought both new and old together, which began to bridge the gap. It has brought stronger relationships with those coworkers who work in the different facilities in the Netherlands, China and the USA. It has also had a significant impact on those Dutch coworkers who tend to see charitable works more the responsibility of the government rather than the corporation. All of these connections have strengthened the relationships among coworkers that has created teambuilding, retention of coworkers and attracts new workers.

Fourth, the spiritual gifts received and connections made are beyond measure. After seven years of trips, there is a community of Dominicans who not only pray and fast for the project, but they pray for the individual coworkers and for the company as a whole. This relationship between Dominicans and Americans has brought a spiritual dimension that is captured by Benedict's notion of fraternity:

As society becomes ever more globalized, it makes us neighbors but does not make us brothers. Reason, by itself, is capable of grasping the equality between men and of giving stability to their civic coexistence, but it cannot establish fraternity. This originates in a transcendent vocation from God the Father, who loved us first, teaching us through the Son what fraternal charity is. ${ }^{24}$

Such spiritual and relational intimacy the moves people into a familial relationship of brothers and sisters in business-related community outreach projects will make most executives uneasy. And it should. Intimate relationships can easily disorder and unrealistic expectations can come from either side. Reell, for example, has been very clear with the Dominicans that there are limits of what they can do and that the ultimate end of

${ }^{24}$ Caritas in Veritate, 19. 
the project is to get to a place where Dominicans are self-supporting. But the spiritual relationship has been one of the surprises of the project. It natural emerged rather than orchestrated.

Finally, a brief note on the relationship and tensions among the charitable, creative and distributive functions of good wealth. First, in relation to creation. If the company does not create wealth, it cannot give it away. Since implementing the DR project, the company's profit have been extremely healthy. This does not mean that economic challenges will not return to the company, but as profound as the charity giving has been, it is dependent upon profit. To be a profitable and well-run company you have to have the right people in the organization. In the span of these seven years, the CEO and the Vice President of Coworker Services (human resources) has had to let several people go for various reasons including some key leadership positions who have actually been on the DR trip. It is not easy to fire someone who you have worked arm in arm on such a charitable cause. But if coworkers are not contributing to the overall good of the company, leadership must first attempt to help toward that goal and if it does not work, they must let them go.

Second, not all coworkers of the company have been committed to the project and some have even expressed that the company tithe should be eliminated and redistributed to them. While this is less of a problem today than it was seven years ago, coworkers can be just as self-interested as shareholders and executives. Self-interest ordered toward one's own wealth maximization damages culture. It highlighted the importance for executives that charity was not fully incorporated in the culture of the company. In those seven years, however, the DR project has been one of the most important activities of contributing to what it means to be charitable not only to the poor but to each other. Coworkers and those board members who go to the DR first experience a deep sense of what has been given to them. They are thinking not that they should have more, but they experience a deep sense of gratitude. In that gratitude, then, is a welling up of a desire to give. Charity is a love of receiving and giving and it becomes a habit not only with those in the DR, but in the business back in Minnesota. Charity purifies wealth and makes it good by reminding us of where it ultimately comes from. 


\section{CONCLUSION}

One of the principal challenges of modernity is a divided life that fragments a moral ecology that frustrates moral and spiritual meaning, deeper relationships and a unity of life. With regard to wealth, we are prone to fragment its creative, distributive and charitable functions into discrete separate units. If we are to generate good wealth, we need to create as good stewards, distribute as agents of justice and give it away as charitable lovers. But these are not three distinct and separate virtues but they mutually inform each other in a way that generates what this paper has called a moral ecology. This moral ecology is premised on virtues that are related to another and if one is missing the other begins to become disordered. This is what people like Aquinas and others call the "unity of the virtues." So what makes "good wealth" good is precisely the virtues of a moral ecology that fosters an interdependent and organic relationship among its creative, distributive and charitable dimensions. One dimension is related to other which is why it is not helpful to juxtapose wealth creation and wealth distribution or charity and justice. Once we are in this frame of mind we are outside of a moral ecology and have fallen tramp to what Alasdair MacIntyre has called compartmentalization, where contemporary social life is separate "into distinct spheres, each with its own highly specific standards of success and failure, each presenting to those initiated into its particular activities its own highly specific normative expectations, each requiring the inculcation of habits designed to make one effective in satisfying those particular expectations and conforming to those particular standards." 25 The principal challenge is not dividing these three areas of creation, distribution and charitable but providing a social vision of how they are related. As expressed in this paper, this is not an easy work and it behooves us to open ourselves to deeper connections among the three functions of wealth. Within this moral ecology, we can begin to see our blind spots not in a judgmental moralistic way, but in a way of humility of receiving the deeper truths of our humanity and our world.

${ }^{25}$ Alasdair MacIntyre, "Moral Philosophy and Contemporary Social Practice: What Holds Them Apart?" The Tasks of Philosophy. Selected Essays, vol. 1 (Cambridge: Cambridge University Press, 2006), 117. 


\section{BIBLIOGRAPHY}

Bailey, James P. Rethinking Poverty, Income, Assets and the Catholic Social Justice Tradition. Notre Dame, IN: University of Notre Dame Press, 2010.

Bockelman, Wilfred. Culture of Corporate Citizenship: Minnesota's Business Legacy for the Global Future, 34. Lakeville: Galde Press, 2000.

Calvez, Jean-Yves and Jacques Perrin. The Church and Social Justice: The Social Teachings of the Popes from Leo XIII to Pius XII, 149. Chicago: Henry Regnery, 1961.

Godbout, Jacques. The World of the Gift, 69. Montreal: McGill-Queen's University Press, 1998.

Kennedy, Robert. The Good That Business Does. Grand Rapids: Acton Institute, 2006.

Lewis, V. Bradley. "Is the Common Good and Ensemble of Conditions." Archivio di Filosofia LXXXIV, no. 1-2 (2016): 130.

MacIntyre, Alasdair. "Moral Philosophy and Contemporary Social Practice: What Holds Them Apart?" In The Tasks of Philosophy. Selected Essays, vol. 1, 117. Cambridge: Cambridge University Press, 2006.

Murray, Charles. Coming Apart: The State of White America, 1960-2010. New York, NY: Crown Forum, 2012.

Naughton, Michael and David Specht. Leading Wisely in Difficult Times: Three Cases on Faith and Work (co-author David Specht). Mahwah: Paulist Press, 2011.

Pieper, Josef. Leisure the Basis of Culture. South Bend, IN: St. Augustine's Press, 1998.

Rahner, Karl. "Theological Remarks on the Problem of Leisure." In Theological Investigations, vol. IV, 379, trans. Kevin Smyth. Baltimore: Helicon Press, 1966.

Ratzinger, Joseph. Introduction to Christianity, trans. J. R. Foster, 266. San Francisco: Ignatius Press, 1990.

Schindler, David. "Christology and the Imago Dei: Interpreting Gaudium et spes." Communio 23 (Spring 1996): 159.

Sheen, Fulton. Justice and Charity, 3. Charlotte: TAN Books, 2016.

Turkson, Cardinal Peter. "Protect the Earth, Dignify Humanity: The Moral Dimensions of Climate Change and Sustainable Development," delivered at Vatican City, April 28, 2015. http://www.casinapioiv.va/content/dam/ accademia/pdf/turkson.pdf. Accessed August 21, 2018.

Vatican's Pontifical Council for Justice and Peace. Vocation of the Business Leader. Vatican City: Pontifical Council for Justice and Peace, 2014. https:// www.stthomas.edu/media/catholicstudies/center/ryan/publications/ publicationpdfs/vocationofthebusinessleaderpdf/PontificalCouncil_4.pdf. 
Open Access This chapter is licensed under the terms of the Creative Commons Attribution 4.0 International License (http://creativecommons.org/licenses/ by $/ 4.0 /$ ), which permits use, sharing, adaptation, distribution and reproduction in any medium or format, as long as you give appropriate credit to the original author(s) and the source, provide a link to the Creative Commons license and indicate if changes were made.

The images or other third party material in this chapter are included in the chapter's Creative Commons license, unless indicated otherwise in a credit line to the material. If material is not included in the chapter's Creative Commons license and your intended use is not permitted by statutory regulation or exceeds the permitted use, you will need to obtain permission directly from the copyright holder.

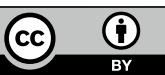




\section{Name Index}

A

Addams, Jane, 178, 179

Akram, Tanweer, 1, 75

Aristotle, 53, 54

B

Barber, II., Reverend William, 191

Becker, Carl, 124

Benedict, Pope, 225-227, 230

Berkeley, George, 5, 111, 112, 114-116, 123, 183

Bilgrami, Akeel, 4, 5, 8, 70

Bradley, Anne, 4, 7

Brooks, Cornell William, 191

Bryan, William Jennings, 180

Butterfield, Herbert, 108, 124

C

Cameron, Andrew, 177, 178

Carnegie, Andrew, 174, 217, 218, 224

Carter, Heather, 6, 8, 173, 177

Chavez, Cesar, 186

Clark, Henry, 8
Costabile, Lilla, 9

D

Dawson, Christopher, 108, 126

De Tocqueville, Alexis, 16

Du Bois, W.E.B., 180, 186

F

Friedman, Milton, 50

G

Gandhi, Mahatma, 4, 5, 53-56, 63, $65,67-70,72$

Gay, Peter, 125

Gerth, Karl, 5, 8, 75, 79, 84, 89, 93

Grudem, Wayne, 32

H

Hardin, Garret, 61

Hayek, F.A., 32, 42, 43, 47, 50

Huerta, Dolores, 186

Hume, David, 54, 109, 125

(C) The Editor(s) (if applicable) and The Author(s) 2020

T. Akram and S. Rashid (eds.), Faith, Finance, and Economy, https://doi.org/10.1007/978-3-030-38784-6 
K

Kaiser, Wolfram, 10

Kai-shek, Chiang, 80

Keynes, John Maynard, 42, 125

King, Jr., Reverend Martin Luther, 186, 191

Kuhn, Thomas, 65

Kutty, Faisal, 6, 8, 129, 131

\section{L}

Lange, Oscar, 42

Lerner, Abba, 42

Locke, John, 18, 58-61, 63, 66, 71, 72

\section{M}

Marx, Karl, 16, 55-57, 59, 64-66

McDaniel, Justin Thomas, 9

McDowell, John, 53

McDowell, Mary, 178

Menger, Carl, 43

Miller, David, 7, 8, 197

Mises, Ludwig von, 32, 41-43

$\mathbf{N}$

Naughton, Michael, 7, 8, 215, 229

Neal, Larry, 9

Nestor, Agnes, 178

O

Ostrom, Elinor, 62

$\mathbf{P}$

Palmer, Tom, 8

Pieper, Josef, 226
Post, Emily, 197, 200, 211

Putnam, Robert, 220

$\mathbf{R}$

Rashid, Salim, 5, 6, 8, 107, 110, 119

Rauschenbusch, Walter, 181-183, 186

Rawls, John, 16, 17

Roosevelt, President Franklin D., 183

\section{$S$}

Samuelson, Paul, 42

Sen, Amartya, 26, 56, 57, 72

Sider, Ronald, 15

Singer, Peter, 16

Swift, Jonathan, 5, 6, 111-120, 123

Swing, David Reverend, 176, 177

$\mathrm{T}$

Tawney, R.H., 125, 126

Tucker, Josiah, 5, 110, 111, 113, $121-123,126$

W

Wallace, George, 189

Washington, Booker T., 180

Weber, Max, 11, 138

Whitehead, Alfred North, 2, 11

$\mathbf{X}$

Xiaoping, Deng, 91, 99, 100

$\mathbf{Z}$

Zedong, Chairman Mao, 79, 80, 90 


\section{SubJect IndeX}

A

Abrahamic, 8

Alienation, 53, 55, 56, 61, 66, 68-71, 222

Austrian School of Economics, 32, 43

\section{B}

The Big Three, 83-86, 99

Bourgeois consumerism, 78, 79, 87, 89,91

C

Canada, 6, 131, 132, 134, 135, 159

Capitalism, 5, 11, 22, 24, 42, 56, 58, $76,79,80,84,91,99,100,126$, 132,174

Catholic social teaching, 184, 215

Charity, 8, 9, 216-218, 224-232

China, People's Republic of (PRC), 78-82, 85, 87, 89-91, 100

Christianity, 6-10, 48, 54, 101, 108-110, 114, 124-126, 138, $175,178-181,184,188,190$

Christ, Jesus, 37, 38, 179, 183
Cold War, 64, 79, 80, 90, 186, 188, 189

Communist Revolution (China) of $1949,5,75,78,79$

Congregationalist Church's Council for Social Action, 187

Congress of Industrial Organizations, 184,185

Consumerism, 4, 5, 75-79, 81-88, 90-93, 98-101

Cultural Revolution (1966-1976), 93, 96

\section{D}

Dicastery for the Promotion of Integral Human Development, 217

Diversity and Inclusion (D\&I), 204-207

Dominican Republic (DR), 229, 231

E

Eastern Europe, 90 
England, 56, 57, 59-61, 111, 116, I

$$
\text { 124-126 }
$$

Equality, 4, 5, 25, 55, 56, 63-67, 69, 107,230

Ethics, 2-4 , 7, 8, 10-12, 53, 68, 108, $109,141,148,201,205,210$, 220

European Union (EU), 10, 110

F Faith, 1-12, 19, 58, 107, 108, 121, $122,124,131,149,157,163$, $165,175,189,190,199-212$, $221,226,228$

Faith-avoiding, 204, 205

Faith-based, 2, 8, 164, 203, 205

Faith-friendly, 7, 203, 205-207, 212

Faith-tolerant, 205

Fatwa, 153, 154, 158

G

Genesis, 4, 31, 32, 37, 42, 220

Getihu (self-employed, household-run business), 92-99

Gharar, 136, 139-141

Gift, 32-34, 39, 43, 45, 46, 83, 85, $98,217,219,220,224-228,230$

Gilded Age, 6, 174, 175, 181, 182, 184,186

God, 4, 10, 18-23, 27, 28, 31-40, $42-46,48,117,118,121,131$, $154,179,181,184-187,189$, $190,192,222,225,228,229$

Good wealth, 6, 7, 215-219, 222, $224,231,232$

$\mathrm{H}$

Haram, 136, 141, 143

Hinduism, 54
Ijarah, 134, 142, 144, 147, 148

India, 2, 24, 54, 56, 57, 88

Industrialization, $5,75,76,82,84$, $85,87,100$

Inequality, 5-8, 11, 24, 25, 64, 65, $69,82,87,173-177,183,184$, $187,189-192,221,222$

The Integration Profile (TIP) Faith and Work Integration Scale, 209, 212

International Monetary Fund, 25

Ireland, 111, 112, 114-116, 122

Islam, 9, 132, 133, 141, 152, 154, 165

Islamic finance, 6, 9, 129-137, 139-144, 148-151, 153-159, 161-165

Istisna, 142, 146-148

$\mathrm{J}$

Judaism, 138

L

Libertarianism, 6, 189

Liberty, 5, 50, 55, 56, 63-69, 71, 116

M

Markets, 4, 15, 16, 23, 24, 26, $40,42,43,45-50,78,82-84$, 88-91, 94, 98-100, 108, 115, $118,122,123,131,133-135$, $143,146,155,156,187,203$, $218,223,224,228$

Materialism, 91

Maysir, 136, 139

Moral ecology, 215, 216, 219, 232

Mudbarabah, 142, 144-146, 148

Muhammad, Prophet, 132, 137

Murababah, 142, 143, 151 
Musharaka, 130, 142, 145, 146, 148

$\mathbf{N}$

National Association of Manufacturers, 187

National Catholic Welfare Conference, 182, 185

Nationalist Party (KMT), 80

Netherlands, 230

New Deal, 183, 184, 187

New Gilded Age, 6, 7, 173, 176, 191, 192

New social teachings, 6,8

"New China", 79, 96

Normative framework, 4, 15-18, 22-24

O

Oikonomia, 32, 37, 38

Old Testament, 17-21, 35-37, 222

$\mathbf{P}$

Perceptual understanding, 71

Political Enlightenment, 55, 67

Profit-loss sharing, 6, 45, 47, 142, $144,146,148,150,164$

Proselytizing, 203

Q

Qimar, 136, 138, 139, 141

$\mathbf{R}$

Rationality, 53, 57-60, 63, 67, 72, 228, 229

Reell Precision Manufacturing, 229

Religious accommodation, 202, 203

Religious harassment, 203, 205

Riba, 129, 136, 137, 141, 142, 152
$S$

Shalom, 32, 35-37, 39

Shariah, 158

Social Christianity, 175, 183, 184, 190, 191

Socialism, 5, 22, 42, 56, 75, 78-80, $82,83,85-88,90,95,99,100$, 132,183

Soviet Union, 42, 49, 90, 188

State consumerism, 87-89

Sukuk, 142, 147, 148

Sunnah, 132, 137

$\mathrm{T}$

Takaful, 142, 147, 148

Target, 228

Three Big Ticket Items, 83

Thrivent, 2, 3

U

United States, 3, 6, 24, 25, 80, 134, $135,139,140,159,174,177$, $183,185,187,200,222$

Usury, 136-138, 152, 165

V

Vatican's Pontifical Council for Justice and Peace. See Dicastery for the Promotion of Integral Human Development

Vocation of the Business Leader, 216, 217

W

Wealth creation, 4, 217, 219, 221, 228,232

Wealth distribution, 217, 221, 223, 232 